Supporting Information for

\title{
Direct and Base-Catalyzed Diboration of Alkynes using The Unsymmetrical Diborane(4), pinB-BMes 2
}

Chiemi Kojima, ${ }^{1}$ Ka-Ho Lee, ${ }^{2}$ Zhenyang Lin, ${ }^{2 *}$ Makoto Yamashita ${ }^{1 *}$

${ }^{1}$ Department of Applied Chemistry, Faculty of Science and Engineering, Chuo University, 1-13-27 Kasuga, Bunkyo-ku, Tokyo 112-8551, Japan

${ }^{2}$ Department of Chemistry, The Hong Kong University of Science and Technology, Clear Water Bay, Kowloon, Hong Kong

*To whom correspondence should be addressed.

E-mail: makoto@oec.chem.chuo-u.ac.jp, chzlin@ust.hk

Table of Contents for Supporting Information

General

S2

Procedure for Table 1

$\begin{array}{ll}\text { run 1 } & \mathrm{S3} \\ \text { runs 2-5 } & \mathrm{S} 4 \\ \text { run 6 } & \mathrm{S8} \\ \text { run } 7 & \mathrm{~S} 9 \\ \text { run } 8 & \mathrm{~S} 10 \\ \text { run } 9 & \mathrm{~S} 11 \\ \text { runs 10-13 } & \mathrm{S} 12 \\ \text { Isolation of 2a } & \mathrm{S} 15 \\ \text { Isolation of 2b and 2c } & \mathrm{S} 16\end{array}$

Procedure for Table 2

$\begin{array}{ll}\text { run 1 } & \mathrm{S} 17 \\ \text { run 2 } & \mathrm{S} 21 \\ \text { run 3 } & \mathrm{S} 24 \\ \text { run } 4 & \mathrm{~S} 28 \\ \text { run 5 } & \mathrm{S31} \\ \text { run 6 } & \mathrm{S35} \\ \text { run 7 } & \mathrm{S36} \\ \text { run 8 } & \mathrm{S} 40 \\ \text { run } 9 & \mathrm{~S} 43\end{array}$

$\begin{array}{ll}\text { run } 10 & \mathrm{~S} 47 \\ \text { run } 11 & \mathrm{S50} \\ \text { run 12 } & \mathrm{S54} \\ \text { run } 13 & \mathrm{S56} \\ \text { run } 14 & \mathrm{S61} \\ \text { run } 15 & \mathrm{S63} \\ \text { run } 16 & \mathrm{~S} 65\end{array}$

Procedure for Scheme 5

Synthesis of 4

Synthesis of 5a,b $\quad$ S67

Procedure for Scheme 6

$\begin{array}{ll}\text { Isolation of } 6(\text { thf })_{2} & \mathrm{~S} 70 \\ \text { Isolation of } 7(\text { thf })_{2} & \mathrm{~S} 72 \\ \text { Reactions of } 7(\text { thf })_{2} & \mathrm{~S} 73\end{array}$

Procedure for Scheme 8

Synthesis of 9a,d S75

Synthesis of 11a,d $\quad$ S75

Photophysical study on 11a,d $\quad$ S79

Details for X-ray analysis $\quad \mathbf{S 8 0}$

Computational Details $\quad \mathbf{S 9 2}$

$\begin{array}{ll}\text { References } & \mathbf{S 9 8}\end{array}$ 


\section{Experimental section}

\section{General}

All manipulations of air- and/or moisture-sensitive compounds were carried out under an argon atmosphere using standard Schlenk and glovebox (Miwa MFG, KIYON) techniques. All glassware were dried for 20 min in the $250{ }^{\circ} \mathrm{C}$ oven before use. THF, $\mathrm{Et}_{2} \mathrm{O}$, toluene, and $n$-hexane were purified by passing through a solvent purification system (Grass Contour). $\mathrm{C}_{6} \mathrm{D}_{6}$ and toluene- $d_{8}$ were dried by distillation over sodium-benzophenone followed by vacuum transfer. DME (1,2-dimethoxyethane, ethylene glycol dimethyl ether) was purchased from Kanto Chemical (dehydrated -Super-) and was used without purification. The unsymmetrical diborane(4) $\mathbf{1}^{1}$ and 8-ethynylquinoline ${ }^{2}$ were prepared according to the reported procedure. Phenylacetylene, 4-octyne, 1-octyne and 1-phenyl-1-propyne were purchased from TCI chemical and were degassed by freeze-pump-thaw cycles before use. $\left(\mathrm{CF}_{3} \mathrm{SO}_{2}\right)_{2} \mathrm{O}$, 1,3,5-trimethoxybenzene, (4-bromophenyl)diphenylamine, $\mathrm{Pd}\left(\mathrm{PPh}_{3}\right)_{4}, \quad \mathrm{Et}{ }_{3} \mathrm{~N} \cdot \mathrm{HCl}, \quad$ and 1-ethynyl-4-fluoroaniline were purchased from TCI Chemical and were directly used without purification. A hexane solution of ${ }^{n} \mathrm{BuLi}$ was purchased from Kanto Chemical. Iodomethane was purchased from Kanto Chemical and was degassed by freeze-pump-thaw cycles and was dried by passing through a pad of alumina before use. 1-ethynyl-N,N-dimethylaniline, XPhos Pd G2 catalyst, 1-bromo-4-ethynylbenzene, and cyclohexylacetylene were purchased from Aldrich and were used without purification. Column chromatography was performed with silica-gel $60 \mathrm{~N}$ (Kanto Chemical). Purification with recycling GPC was performed with Prominence system (Shimadzu) consisting of LC-20AR, RID-10A, CBM-20A, and 40ф JAIGEL-1H\&2H (Japan Analytical Industry) columns with use of 1,2-dichloroethane as an eluent. The nuclear magnetic resonance (NMR) spectra were recorded on JEOL ECA-500 $\left(500 \mathrm{MHz}\right.$ for ${ }^{1} \mathrm{H}, 126 \mathrm{MHz}$ for ${ }^{13} \mathrm{C}, 161 \mathrm{MHz}$ for ${ }^{11} \mathrm{~B}$, and $194 \mathrm{MHz}$ for ${ }^{7} \mathrm{Li}$ ) or JEOL ECS-400 (400 MHz for ${ }^{1} \mathrm{H}, 101 \mathrm{MHz}$ for ${ }^{13} \mathrm{C}, 129 \mathrm{MHz}$ for $\left.{ }^{11} \mathrm{~B}\right)$. Chemical shifts are reported in $\delta$ ppm relative to the residual protiated solvent for ${ }^{1} \mathrm{H}$, deuterated solvent for ${ }^{13} \mathrm{C}$, and an external $\mathrm{BF}_{3} \cdot \mathrm{OEt}_{2}$ for ${ }^{11} \mathrm{~B}$ used as references. The absolute values of the coupling constants are given in Hertz (Hz). Multiplicities are abbreviated as singlet (s), doublet (d), triplet (t), quartet (q), multiplet (m), and broad (br). Elemental analyses were performed at the A Rabbit Science Co., Ltd. Mass spectra were measured on a JEOL JMS-700 mass spectrometer. Melting points (m.p.) were determined with a MPA100 OptiMelt (Tokyo Instruments, Inc.) and were uncorrected. X-ray crystallographic analyses were performed on VariMax/Saturn CCD diffractometer. IR spectrum was recorded on Cary 630 spectrometer (Agilent) equipped with diamond ATR attachement. UV/vis spectrum was recorded on UV-3600 (Shimadzu) spectrometer. Fluorescent spectrum was recorded on FP-8200 (JASCO) spectrofluorometer. Quantum yields were measured by using C9920-03G (Hamamatsu). Lifetime measurement was performed by using Quantaurus-Tau: C11367-11 (Hamamatsu). 


\section{Estimation of NMR yields in Table 1}

\section{Reaction of 1 with phenylacetylene without additive in toluene at $100{ }^{\circ} \mathrm{C}$ (Table 1 , run 1)}

In a glovebox, to a toluene $(1.0 \mathrm{~mL})$ solution of $1(75.0 \mathrm{mg}, 0.200 \mathrm{mmol})$, phenylacetylene $(24.0 \mu \mathrm{L}, 0.220 \mathrm{mmol})$ was added. After stirring the reaction mixture at $100{ }^{\circ} \mathrm{C}$ for $37 \mathrm{~h}$, volatiles were removed from the pale green solution in vacuo. After an addition of trimethoxybenzene (internal standard, $16.8 \mathrm{mg}, 0.100 \mathrm{mmol}$ ) and $\mathrm{C}_{6} \mathrm{D}_{6}$ $(1.00 \mathrm{~mL})$ to the crude product $(102 \mathrm{mg})$, an aliquot $(0.600 \mathrm{~mL})$ was pipetted to an NMR tube. The ${ }^{1} \mathrm{H}$ NMR yields $(\mathbf{2 a}, 69 \% ; \mathbf{2 b}, 30 \% ; \mathbf{2 c}, 0 \%)$ of the products were estimated by comparison of the integral ratio of each product with those of the isolated compounds (Figure S1). Procedure for isolation of 2a-c is described below.

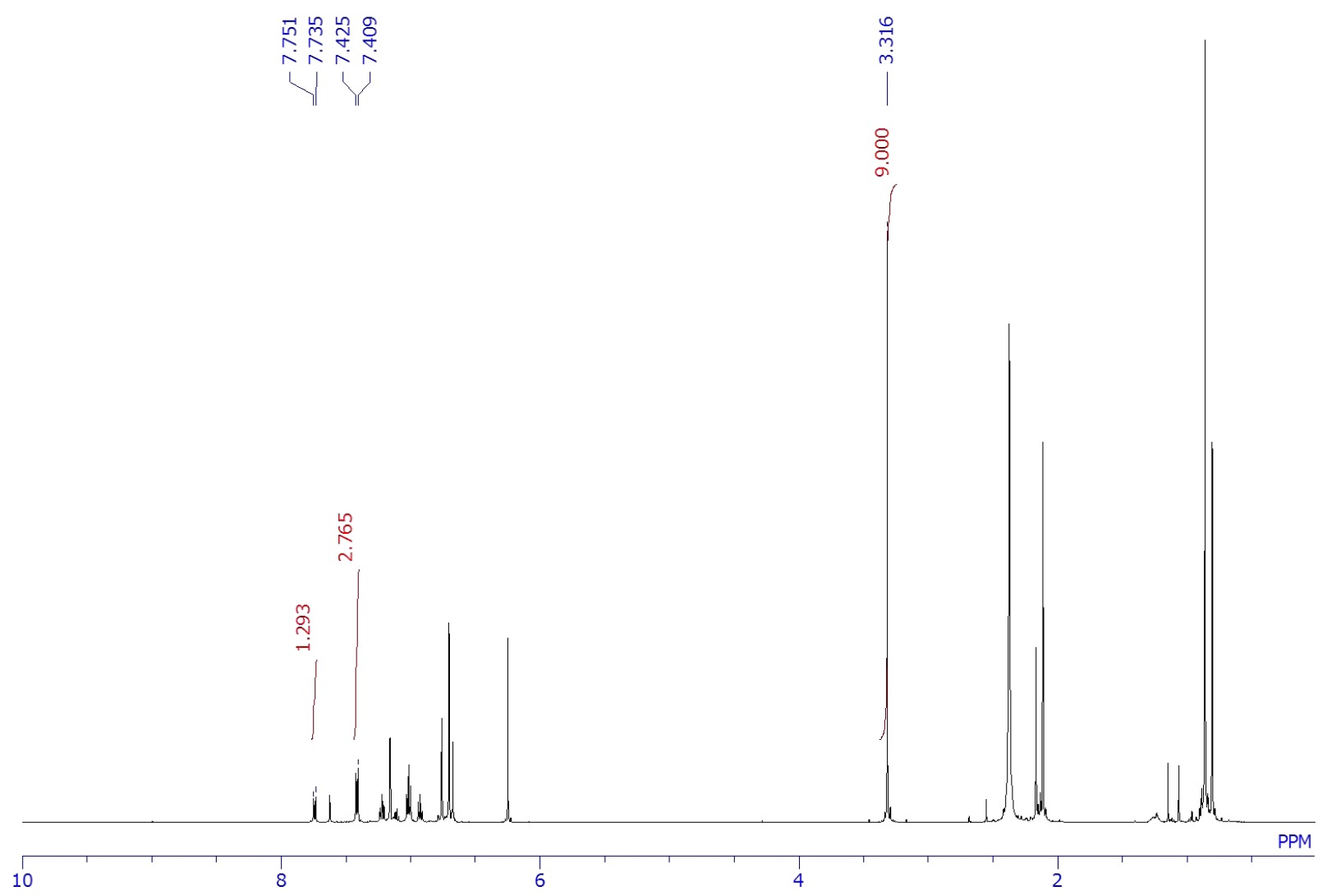

Figure S1. The ${ }^{1}$ H NMR spectrum of the reaction mixture in run 1, Table 1 (7.74 ppm: $2 \mathbf{b} ; 7.42$ ppm: $\mathbf{2 a} ; 3.32$ ppm: internal standard, 1,3,5-trimethoxybenzene) 


\section{Procedure for the reactions in runs 2-5 in Table 1}

In a glovebox, to a solution of phenylacetylene in toluene or THF, ${ }^{n} \mathrm{BuLi}$ in hexane was added dropwise at $-35^{\circ} \mathrm{C}$. After stirring the reaction mixture at room temperature for $3 \mathrm{~min}, \mathbf{1}$ was added to a mixture at room temperature. After the resulting mixture stirred at the indicated temperature for an appropriate time, volatiles were removed from the resulting solution in vacuo. After an addition of trimethoxybenzene (internal standard) and $\mathrm{C}_{6} \mathrm{D}_{6}(1.00$ $\mathrm{mL})$ to the crude product, an aliquot $(0.600 \mathrm{~mL})$ was pipetted to an NMR tube. The ${ }^{1} \mathrm{H}$ NMR yields of the products were estimated by comparison of the integral ratio of each product with those of the isolated compounds. Procedure for isolation of $\mathbf{2 a - c}$ is described below.

\section{Conditions and results for run 2}

Toluene $(500 \mu \mathrm{L}), 1(37.7 \mathrm{mg}, 0.100 \mathrm{mmol})$, phenylacetylene (12.0 $\mu \mathrm{L}, 0.110 \mathrm{mmol}),{ }^{n} \mathrm{BuLi}(2.69 \mathrm{M}, 5.70 \mu \mathrm{L}$, $15.0 \mu \mathrm{mol}), 100{ }^{\circ} \mathrm{C}, 17 \mathrm{~h}$, trimethoxybenzene $(10.1 \mathrm{mg}, 0.0601 \mathrm{mmol})$, crude prduct (53.0 mg); NMR yield: $\mathbf{2 a}$, $10 \% ; \mathbf{2 b}, 61 \% ; \mathbf{2 c}, 8 \%$. See Figure S2 for NMR spectrum of the crude product.

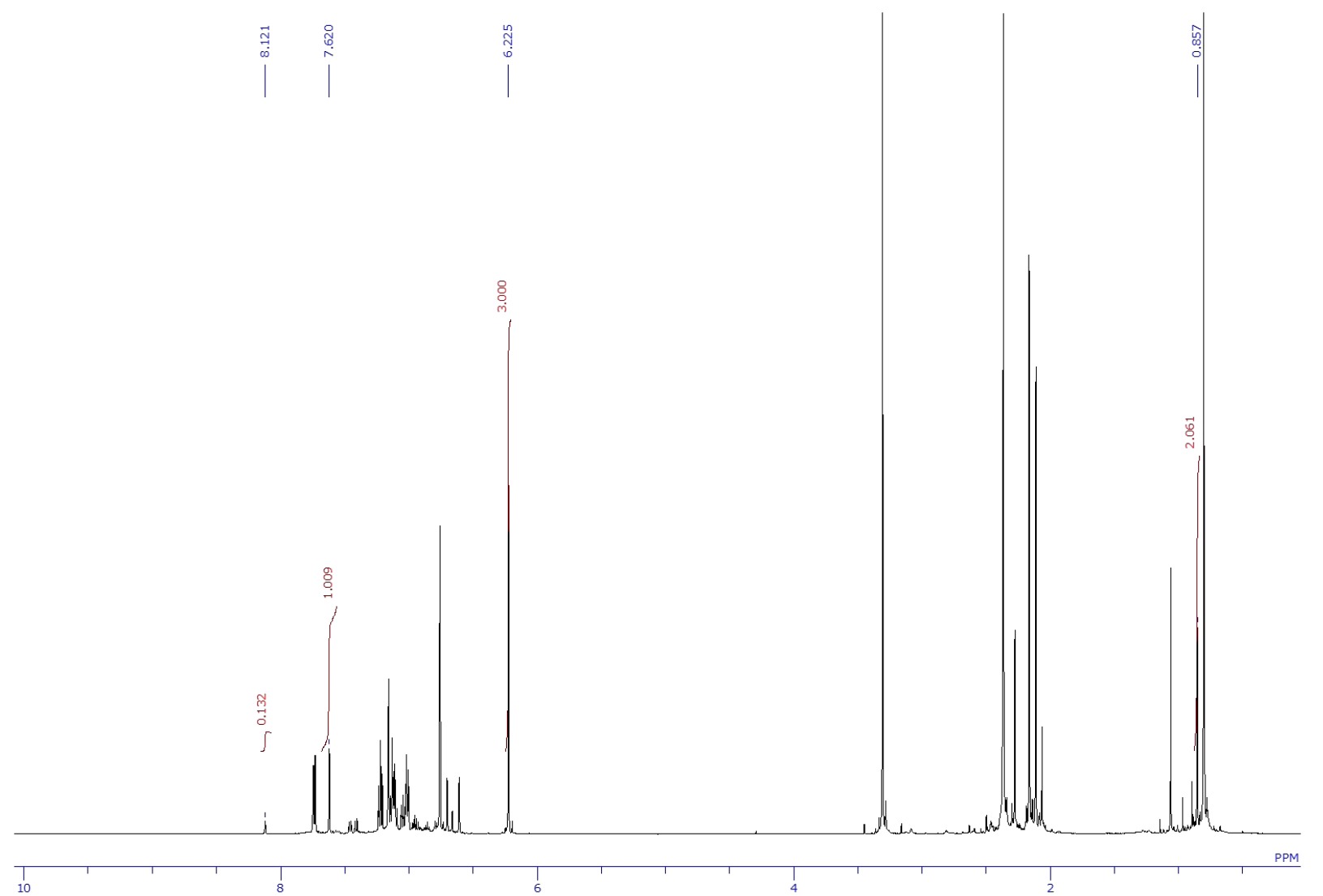

Figure S2. The ${ }^{1}$ H NMR spectrum of the reaction mixture in run 2, Table 1 (8.12 ppm: 2 c; 7.62 ppm: $2 \mathbf{b} ; 0.86$ ppm: 2a; 6.23 ppm: internal standard, 1,3,5-trimethoxybenzene) 


\section{Conditions and results for run 3}

THF $(500 \mu \mathrm{L}), 1(37.6 \mathrm{mg}, 0.100 \mathrm{mmol})$, phenylacetylene $(12.0 \mu \mathrm{L}, 0.110 \mathrm{mmol}),{ }^{n} \mathrm{BuLi}(2.69 \mathrm{M}, 5.70 \mu \mathrm{L}, 15.0$ $\mu \mathrm{mol}), 70^{\circ} \mathrm{C}, 19 \mathrm{~h}$, trimethoxybenzene (10.1 mg, $\left.0.0601 \mathrm{mmol}\right)$ crude product (54.2 mg); NMR yield: 2a, 21\%; 2b, 7\%; 2c, 56\%. See Figure S3 for NMR spectrum of the crude product.

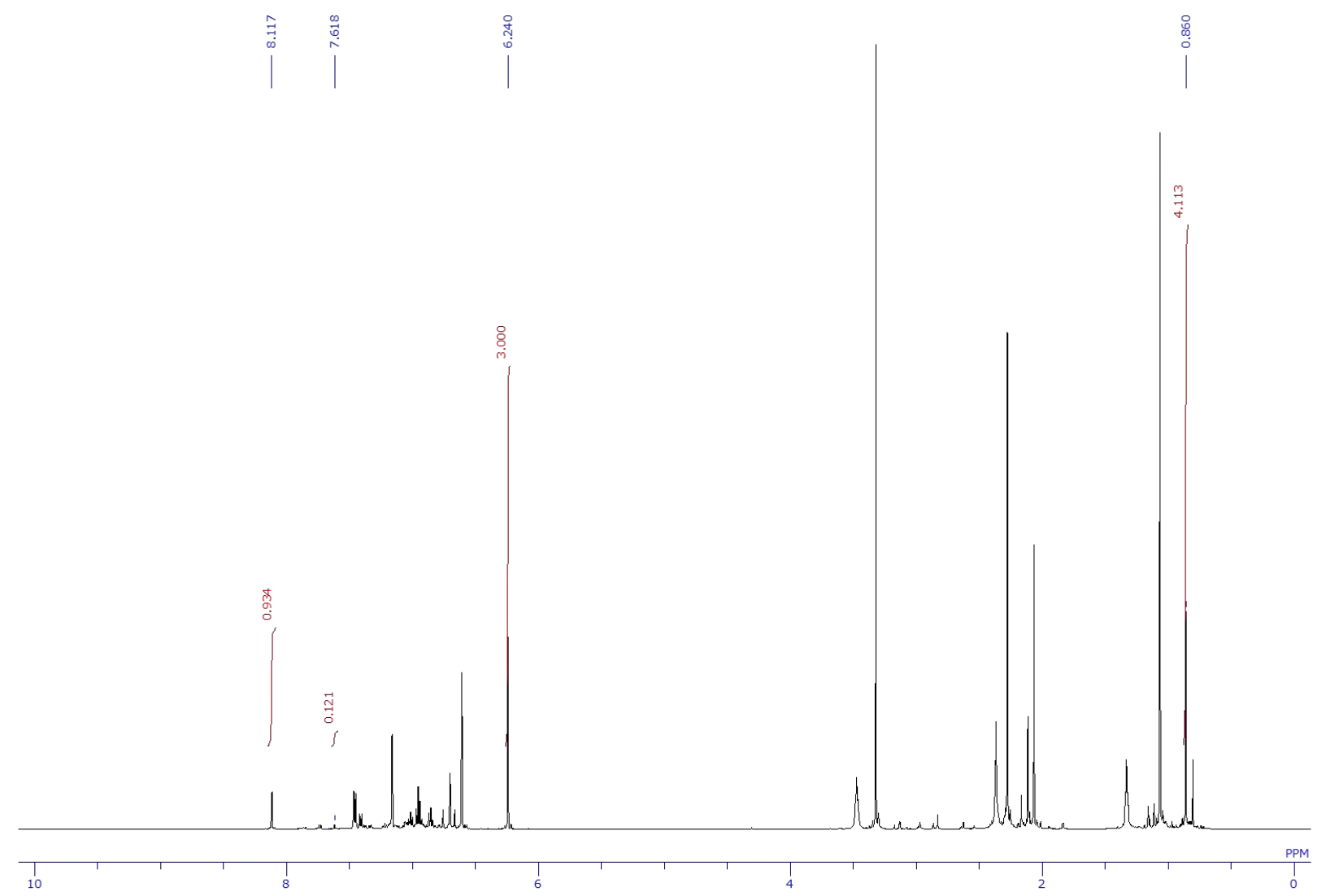

Figure S3. The ${ }^{1} \mathrm{H}$ NMR spectrum of the reaction mixture in run 3, Table 1 (8.12 ppm: 2c; 7.62 ppm: $2 \mathbf{b} ; 0.86$ ppm: 2a; 6.23 ppm: internal standard, 1,3,5-trimethoxybenzene) 


\section{Conditions and results for run 4}

Hexane (1.00 mL), 1 (75.8 mg, $0.202 \mathrm{mmol})$, phenylacetylene $(24.5 \mu \mathrm{L}, 0.223 \mathrm{mmol}),{ }^{n} \mathrm{BuLi}(2.69 \mathrm{M}, 11.5 \mu \mathrm{L}$, $30.0 \mu \mathrm{mol}), 80^{\circ} \mathrm{C}, 19 \mathrm{~h}$, trimethoxybenzene $(17.3 \mathrm{mg}, 0.103 \mathrm{mmol})$ crude product $(99.8 \mathrm{mg})$; NMR yield: $2 \mathrm{a}$, $18 \% ; \mathbf{2 b}, 9 \% ; \mathbf{2}$, $53 \%$. See Figure S4 for NMR spectrum of the crude product.

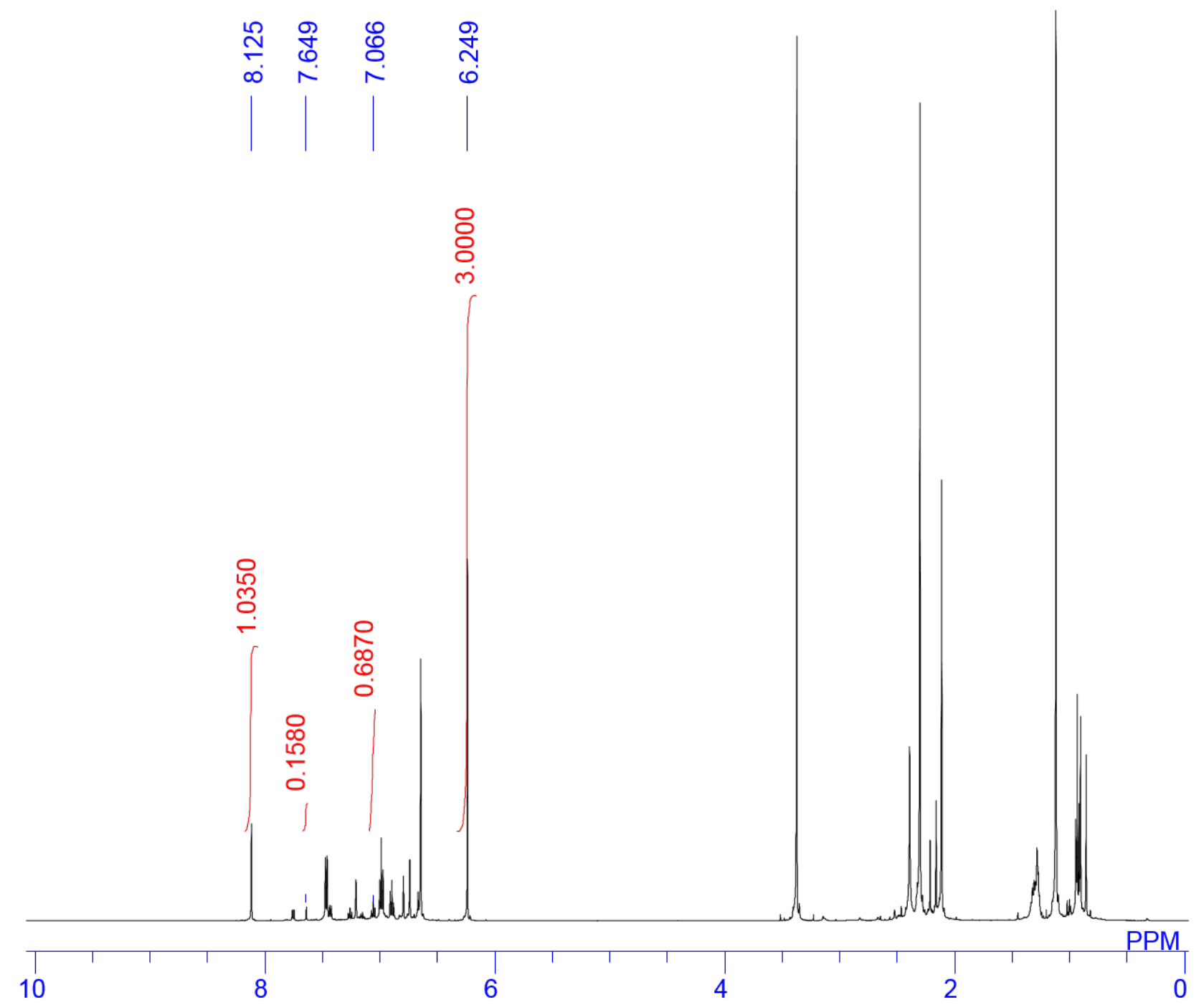

Figure S4. The ${ }^{1} \mathrm{H}$ NMR spectrum of the reaction mixture in run 4, Table 1 (7.06 ppm: $2 \mathbf{a} ; 7.65$ ppm: $\mathbf{2} \mathbf{b} ; 8.12$ ppm: 2c; 6.25 ppm: internal standard, 1,3,5-trimethoxybenzene) 


\section{Conditions and results for run 5}

Toluene $(500 \mu \mathrm{L}), 1(37.6 \mathrm{mg}, 0.100 \mathrm{mmol})$, phenylacetylene $(12.0 \mu \mathrm{L}, 0.110 \mathrm{mmol}),{ }^{n} \mathrm{BuLi}(2.69 \mathrm{M}, 5.70 \mu \mathrm{L}$, $15.0 \mu \mathrm{mol}), 40{ }^{\circ} \mathrm{C}, 42 \mathrm{~h}$, trimethoxybenzene $(10.1 \mathrm{mg}, 0.0601 \mathrm{mmol})$ crude product $(50.3 \mathrm{mg})$; NMR yield: 2a, $14 \% ; \mathbf{2 b}, 9 \% ; \mathbf{2}$, $58 \%$. See Figure S5 for NMR spectrum of the crude product.

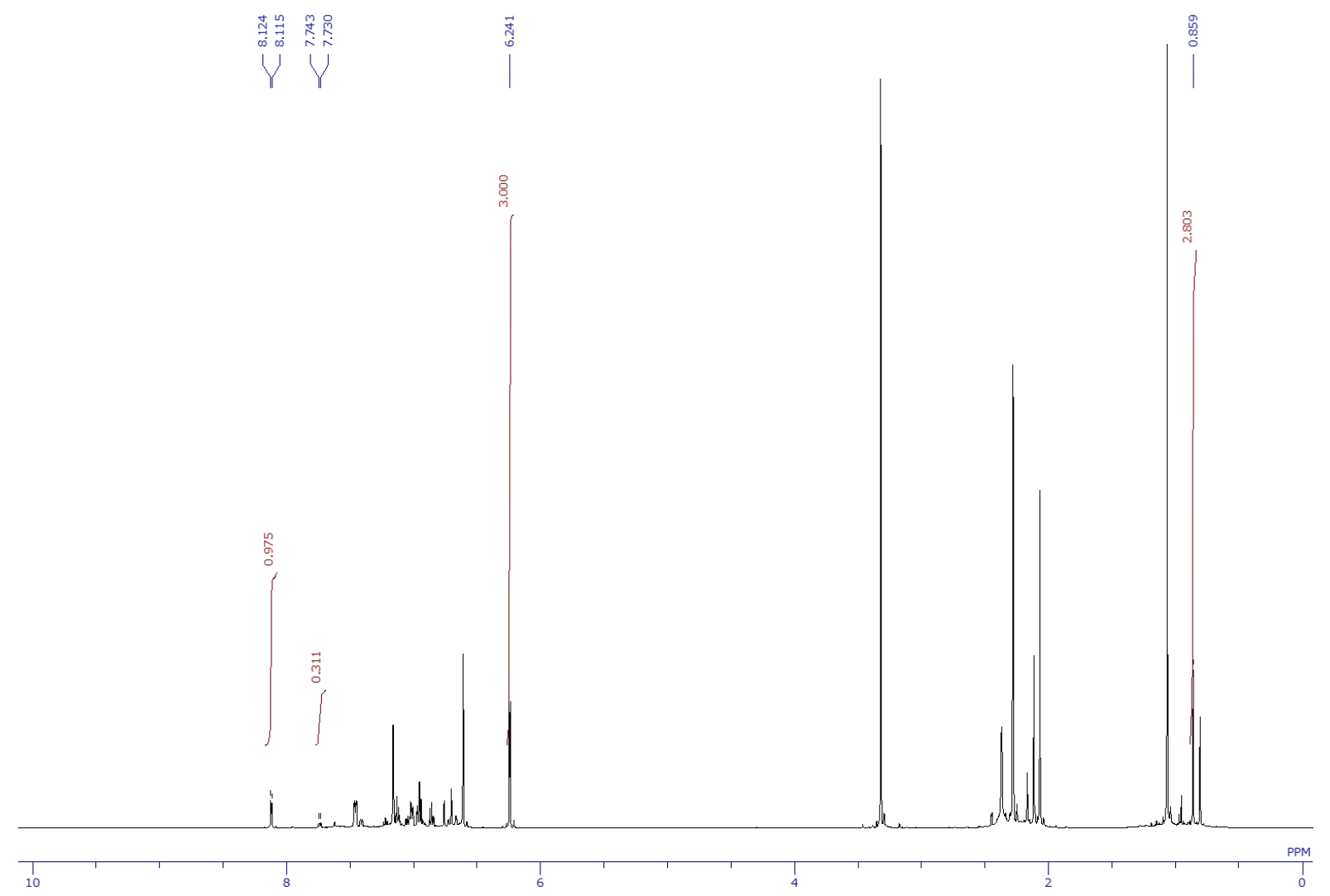

Figure S5. The ${ }^{1} \mathrm{H}$ NMR spectrum of the reaction mixture in run 5, Table 1 (8.12 ppm: $2 \mathbf{c} ; 7.74$ ppm: $2 \mathbf{b} ; 0.86$ ppm: 2a; 6.23 ppm: internal standard, 1,3,5-trimethoxybenzene) 


\section{Conditions and results for run 6}

THF (500 $\mu \mathrm{L}), 1(37.6 \mathrm{mg}, 0.100 \mathrm{mmol})$, phenylacetylene (12.0 $\mu \mathrm{L}, 0.110 \mathrm{mmol}),{ }^{n} \mathrm{BuLi}(2.69 \mathrm{M}, 5.70 \mu \mathrm{L}, 15.0$ $\mu \mathrm{mol}), 40{ }^{\circ} \mathrm{C}, 88 \mathrm{~h}$, trimethoxybenzene (10.1 mg, $\left.0.0601 \mathrm{mmol}\right)$ crude product (48.5 mg); NMR yield: 2a, 30\%; 2b, 14\%; $\mathbf{2 c}, 37 \%$. See Figure S6 for NMR spectrum of the crude product.

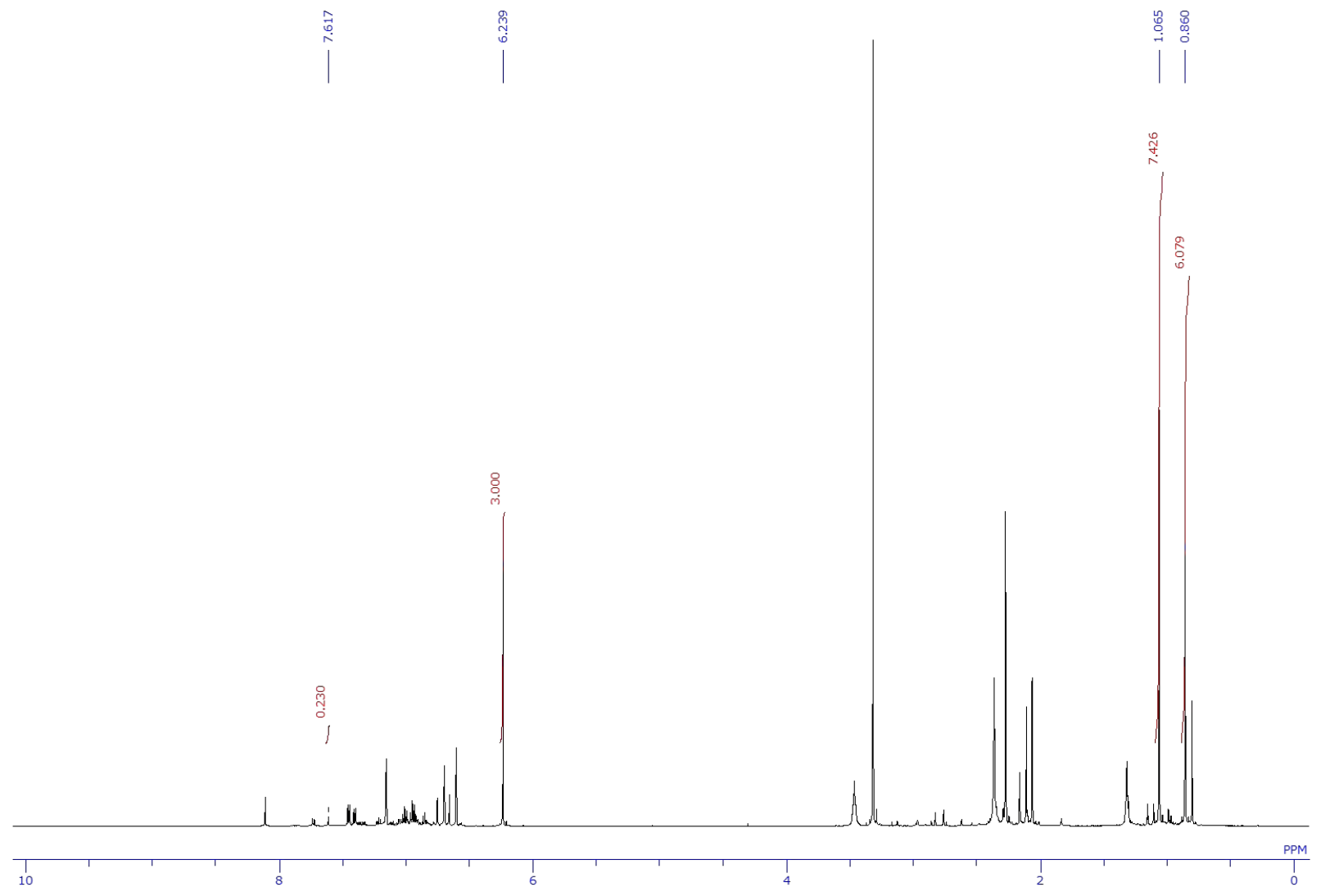

Figure S6. The ${ }^{1} \mathrm{H}$ NMR spectrum of the reaction mixture in run 6, Table 1 (1.07 ppm: $\mathbf{2 c} ; 7.62$ ppm: $2 \mathbf{b} ; 0.86$ ppm: 2a; 6.23 ppm: internal standard, 1,3,5-trimethoxybenzene) 


\section{Conditions and results for run 7}

Hexane $(1.00 \mathrm{~mL}), 1(75.5 \mathrm{mg}, 0.201 \mathrm{mmol})$, phenylacetylene $(24.5 \mu \mathrm{L}, 0.223 \mathrm{mmol}),{ }^{n} \mathrm{BuLi}(2.69 \mathrm{M}, 11.5$ $\mu \mathrm{L}, .30 .0 \mu \mathrm{mol}), 40{ }^{\circ} \mathrm{C}, 96 \mathrm{~h}$, trimethoxybenzene $(16.7 \mathrm{mg}, 0.0994 \mathrm{mmol})$ crude product $(77.5 \mathrm{mg})$; NMR yield: 2a, 34\%; 2b, 14\%; 2c, 23\%. See Figure S7 for NMR spectrum of the crude product.

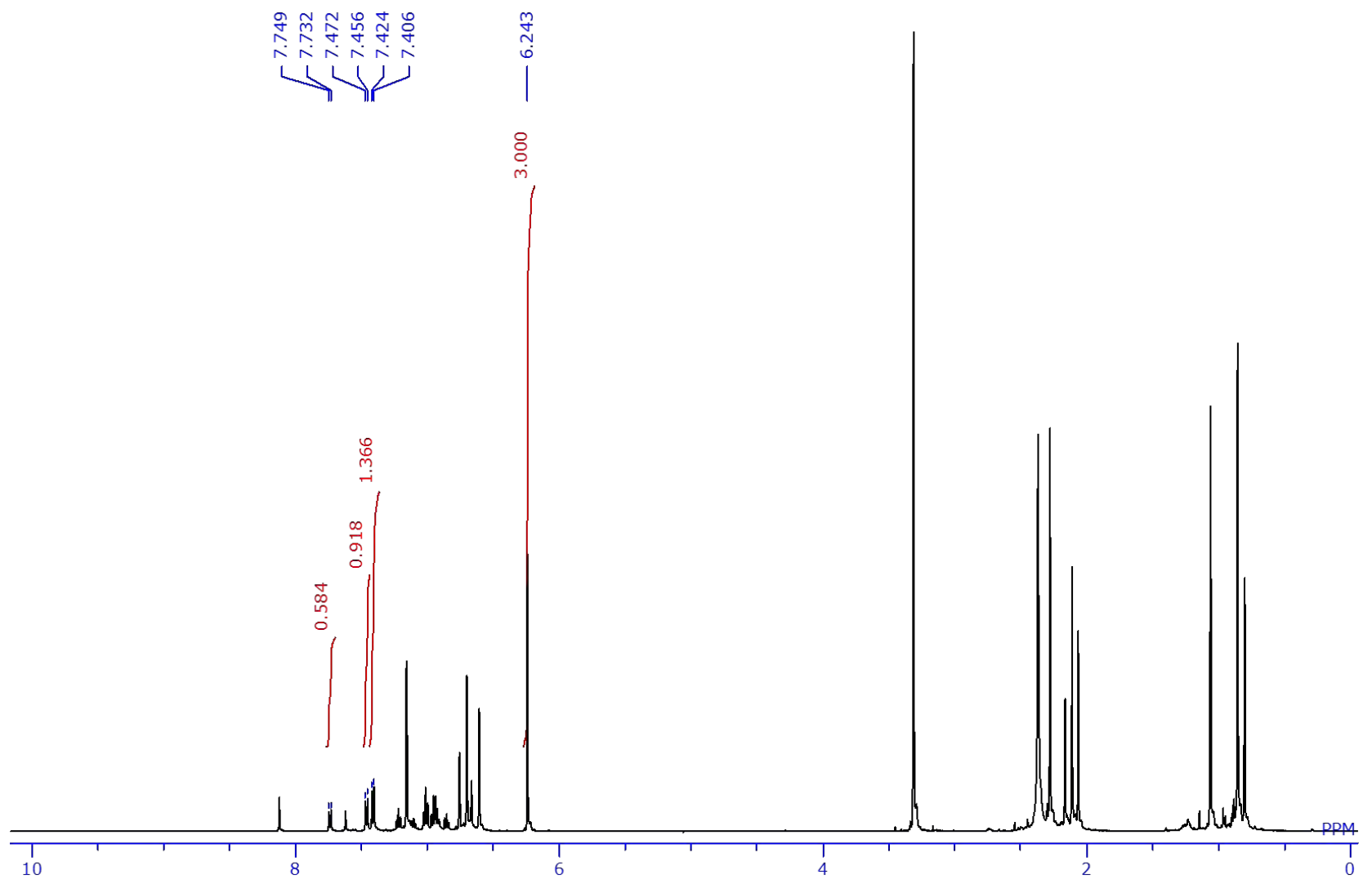

Figure S7. The ${ }^{1}$ H NMR spectrum of the reaction mixture in run 7, Table 1 (7.41 ppm: $2 \mathbf{c} ; 7.74$ ppm: $2 \mathbf{b} ; 7.46$ ppm: 2a; 6.24 ppm: internal standard, 1,3,5-trimethoxybenzene) 


\section{Procedure for the reaction in run 8 of Table 1}

In a glovebox, to a solution of phenylacetylene in toluene $\left(24.1 \mu \mathrm{L}, 0.220 \mathrm{mmol}, 400 \mu \mathrm{L}\right.$ toluene), ${ }^{n} \mathrm{BuLi}$ in hexane $(2.61 \mathrm{M}, 11.5 \mu \mathrm{L}, 30.0 \mu \mathrm{mol})$ was added dropwise at $-35^{\circ} \mathrm{C}$. After stirring the reaction mixture at room temperature for $5 \mathrm{~min}$, a toluene solution $(600 \mu \mathrm{L})$ of $\mathbf{1}(75.2 \mathrm{mg}, 0.200 \mathrm{mmol})$ and 1,3,5-trimethoxybenzene (33.6 $\mathrm{mg}, 0.200 \mathrm{mmol}$ ) was added to the mixture at room temperature. After the resulting mixture stirred at $100{ }^{\circ} \mathrm{C}$ for 1 $\mathrm{h}$, hexane was added to the mixture and then the volatiles were removed from the resulting solution in vacuo. After an addition of $\mathrm{C}_{6} \mathrm{D}_{6}(1.00 \mathrm{~mL})$ to the crude product, an aliquot $(0.600 \mathrm{~mL})$ was pipetted to an NMR tube. The ${ }^{1} \mathrm{H}$ NMR yields of the products were estimated by comparison of the integral ratio of each product with those of the isolated compounds. Procedure for isolation of $\mathbf{2 a - c}$ is described below. NMR yield: $\mathbf{2 a}, 2 \%$; $\mathbf{2 b}, 9 \%$; $\mathbf{2 c}$, $82 \%$. See Figure S8 for NMR spectrum of the crude product.

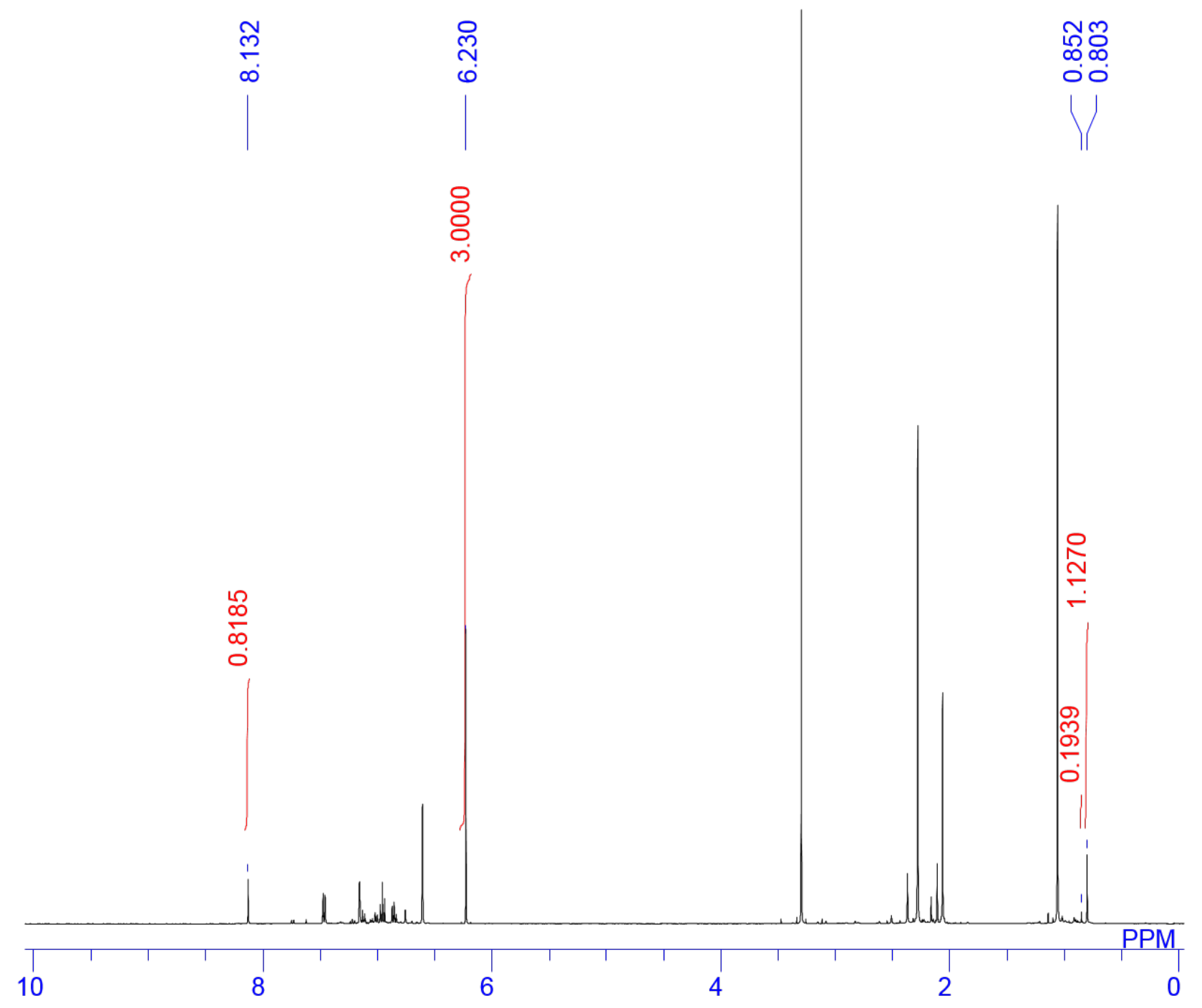

Figure S8. The ${ }^{1}$ H NMR spectrum of the reaction mixture in run 8 , Table 1 (8.13 ppm: $2 \mathbf{c} ; 0.85$ ppm: $\mathbf{2 a} ; 0.80$ ppm: 2b; 6.23 ppm: internal standard, 1,3,5-trimethoxybenzene) 


\section{Procedure for the reaction in run 9 of Table 1}

In a glovebox, to a solution of phenylacetylene in toluene $\left(24.1 \mu \mathrm{L}, 0.220 \mathrm{mmol}, 400 \mu \mathrm{L}\right.$ toluene), ${ }^{n} \mathrm{BuLi}$ in hexane $(2.61 \mathrm{M}, 11.5 \mu \mathrm{L}, 30.0 \mu \mathrm{mol})$ was added dropwise at $-35{ }^{\circ} \mathrm{C}$. After stirring the reaction mixture at room temperature for $5 \mathrm{~min}$, a toluene solution $(600 \mu \mathrm{L})$ of $1(75.2 \mathrm{mg}, 0.200 \mathrm{mmol})$ and anisole $(22.0 \mu \mathrm{L}, 0.200 \mathrm{mmol})$ was added to the mixture at room temperature. After the resulting mixture stirred at $100{ }^{\circ} \mathrm{C}$ for $1 \mathrm{~h}$, hexane was added to the mixture and then the volatiles were removed from the resulting solution in vacuo. After an addition of 1,3,5-trimethoxybenzene $(17.7 \mathrm{mg}, 0.105 \mathrm{mmol})$ and $\mathrm{C}_{6} \mathrm{D}_{6}(1.00 \mathrm{~mL})$ to the crude product, an aliquot $(0.600 \mathrm{~mL})$ was pipetted to an NMR tube. The ${ }^{1} \mathrm{H}$ NMR yields of the products were estimated by comparison of the integral ratio of each product with those of the isolated compounds. Procedure for isolation of 2a-c is described below. NMR yield: $\mathbf{2 a}, 3 \%$; $\mathbf{2 b}, 37 \%$; $\mathbf{2}$, 44\%. See Figure S9 for NMR spectrum of the crude product.

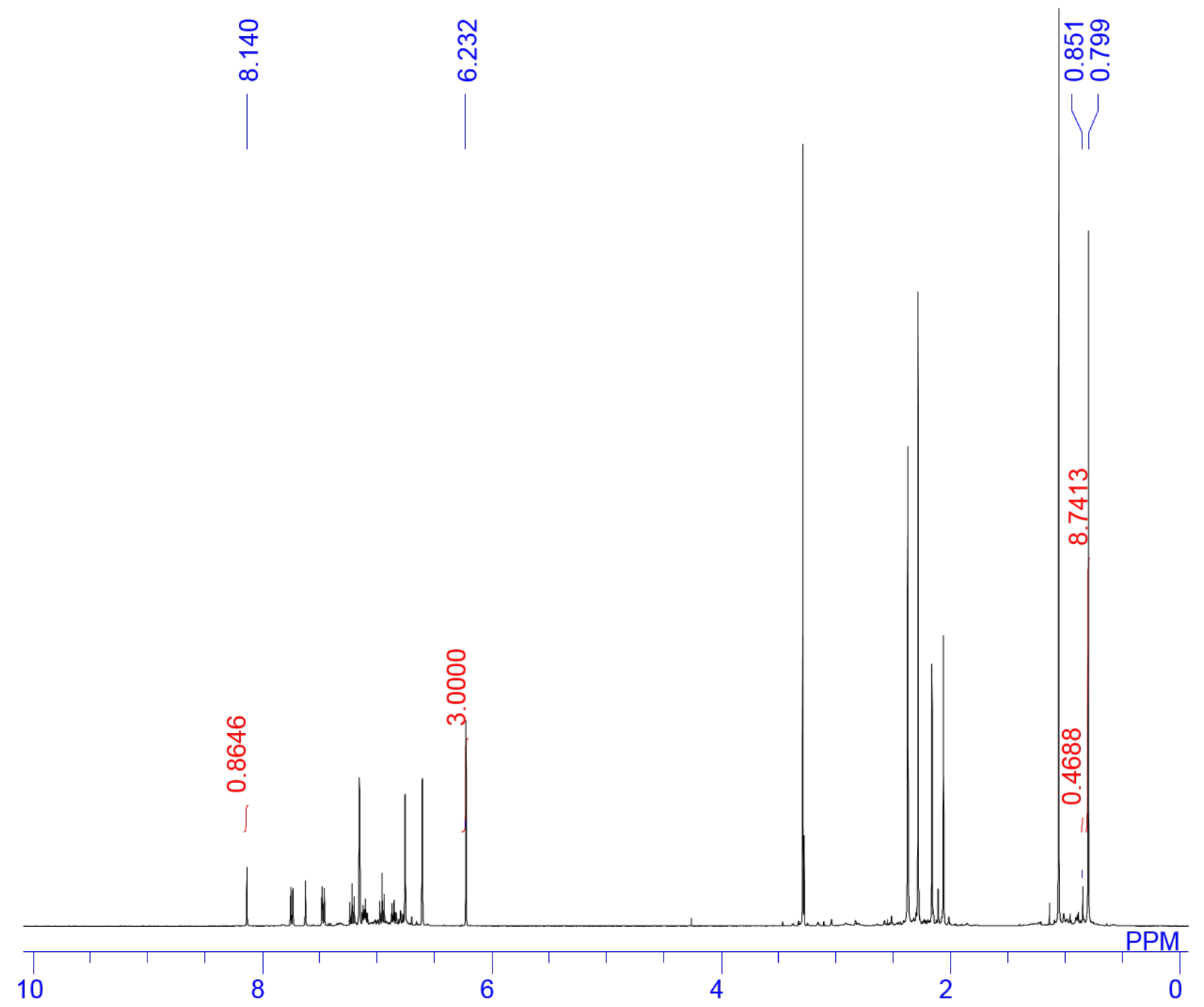

Figure S9. The ${ }^{1}$ H NMR spectrum of the reaction mixture in run 9, Table 1 (8.13 ppm: 2 c; 0.85 ppm: $2 \mathbf{2} ; 0.80$ ppm: 2b; 6.23 ppm: internal standard, 1,3,5-trimethoxybenzene) 


\section{Procedure for the reactions in runs 10-13 in Table 1}

In a glovebox, to a solution of phenylacetylene in toluene (DME in run 11), ${ }^{n} \mathrm{BuLi}$ in hexane was added dropwise at room temperature. After stirring the reaction mixture at room temperature for $3 \mathrm{~min}, \mathbf{1}$ and DME was added to a mixture at room temperature. After the resulting mixture stirred at the indicated temperature for an appropriate time, volatiles were removed from the resulting solution in vacuo. After an addition of trimethoxybenzene (internal standard) and $\mathrm{C}_{6} \mathrm{D}_{6}(1.00 \mathrm{~mL})$ to the crude product, an aliquot $(0.600 \mathrm{~mL})$ was pipetted to an NMR tube. The ${ }^{1} \mathrm{H}$ NMR yields of the products were estimated by comparison of the integral ratio of each product with those of the isolated compounds. Procedure for isolation of 2a-c is described below.

\section{Conditions and results for run 10}

Toluene (1.00 mL), 1 (75.2 mg, $0.200 \mathrm{mmol})$, phenylacetylene $(24.0 \mu \mathrm{L}, 0.220 \mathrm{mmol}),{ }^{n} \mathrm{BuLi}(2.69 \mathrm{M}, 11.5 \mu \mathrm{L}$, $30.0 \mu \mathrm{mol})$, DME $(13.0 \mu \mathrm{L}, 0.200 \mathrm{mmol}), 100{ }^{\circ} \mathrm{C}, 1 \mathrm{~h}$, trimethoxybenzene $(16.9 \mathrm{mg}, 0.101 \mathrm{mmol})$ crude (100.6 mg); NMR yield: 2a, 30\%; 2b, 14\%; 2c, 37\%. See Figure S10 for NMR spectrum of the crude product.

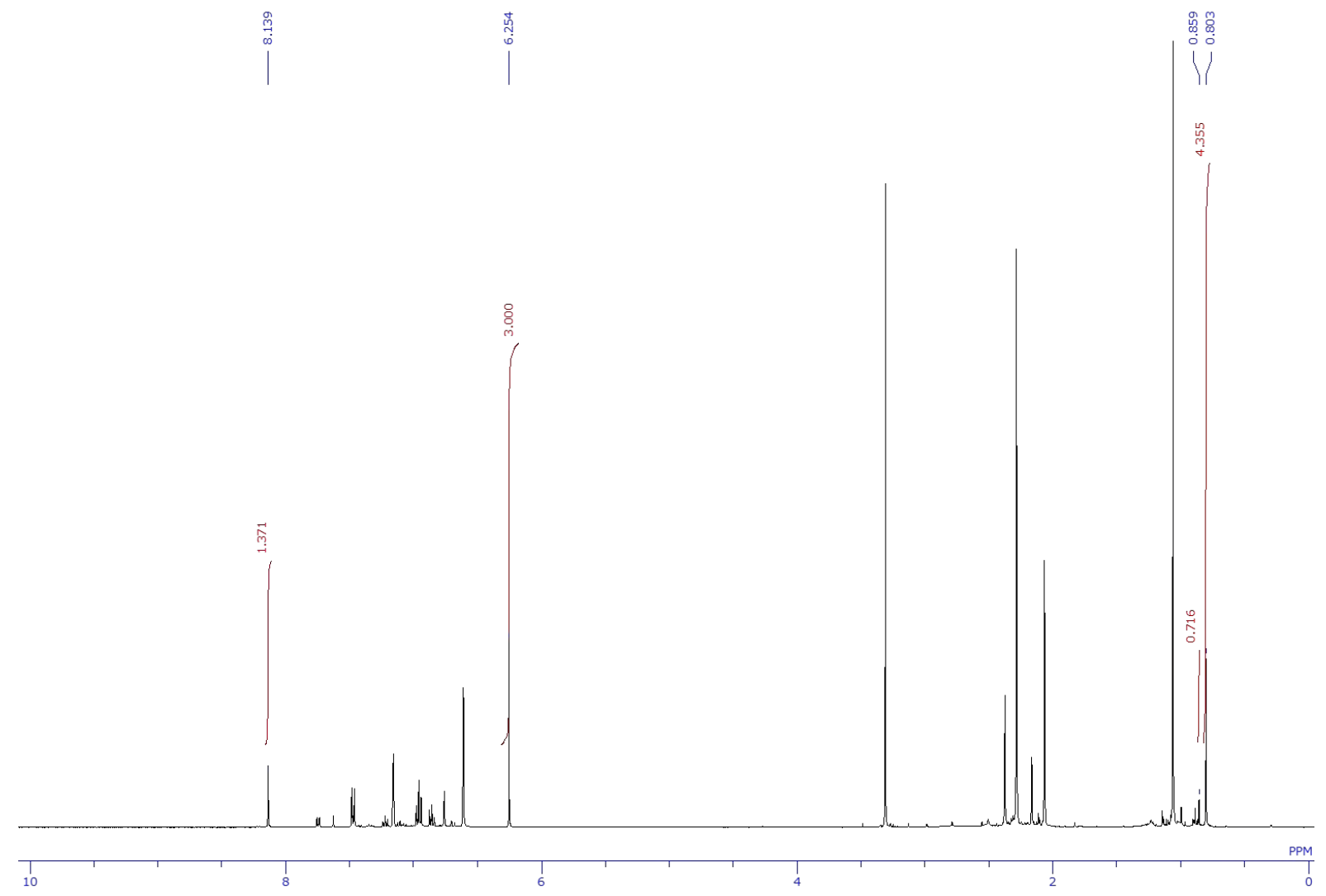

Figure S10. The ${ }^{1} \mathrm{H}$ NMR spectrum of the reaction mixture in run 10, Table 1 (8.14 ppm: 2c; 0.86 ppm: $2 \mathbf{2 a} ; 0.80$ ppm: 2b; 6.23 ppm: internal standard, 1,3,5-trimethoxybenzene) 


\section{Conditions and results for run 11}

DME (1.00 mL), 1 (75.2 mg, $0.200 \mathrm{mmol})$, phenylacetylene (24.0 $\mu \mathrm{L}, 0.220 \mathrm{mmol}),{ }^{n} \mathrm{BuLi}(2.69 \mathrm{M}, 11.5 \mu \mathrm{L}, 30.0$ $\mu \mathrm{mol}), 100{ }^{\circ} \mathrm{C}, 1 \mathrm{~h}$, trimethoxybenzene (17.2 mg, $\left.0.102 \mathrm{mmol}\right)$ crude (108.2 mg); NMR yield: $2 \mathbf{a}, 12 \%$; $2 \mathbf{b}, 13 \%$; 2c, $63 \%$. See Figure S11 for NMR spectrum of the crude product.

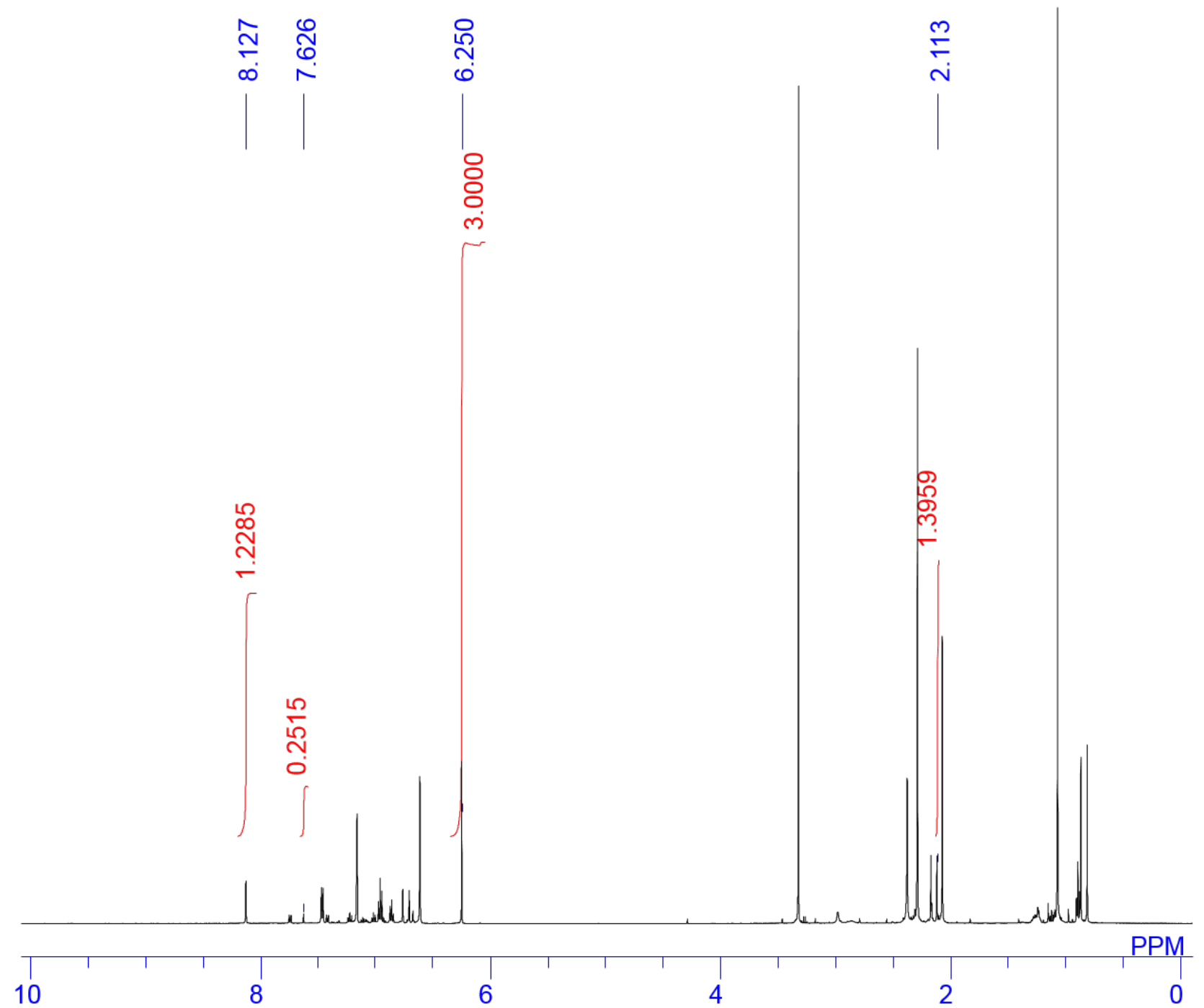

Figure S11. The ${ }^{1}$ H NMR spectrum of the reaction mixture in run 11, Table 1 (2.13 ppm: 1; 8.12 ppm: $\mathbf{2 c} ; 2.16$ ppm: 2b; 2.11 ppm: 2a; 6.23 ppm: internal standard, 1,3,5-trimethoxybenzene) 


\section{Conditions and results for run 12}

Toluene (1.00 mL), 1 (75.2 mg, $0.200 \mathrm{mmol})$, phenylacetylene $(24.0 \mu \mathrm{L}, 0.220 \mathrm{mmol}),{ }^{n} \mathrm{BuLi}(0.100 \mathrm{M}$ diluted in toluene, $60.0 \mu \mathrm{L}, 6.00 \mu \mathrm{mol})$, DME $(0.100 \mathrm{M}$ diluted in toluene, $60.0 \mu \mathrm{L}, 6.00 \mu \mathrm{mol}), 100{ }^{\circ} \mathrm{C}, 1 \mathrm{~h}$, trimethoxybenzene $(16.9 \mathrm{mg}, 0.101 \mathrm{mmol})$ crude $(100.5 \mathrm{mg})$; NMR yield: $\mathbf{2 a}, 16 \% ; \mathbf{2 b}, 9 \% ; \mathbf{2 c}, 67 \% ; \mathbf{1}, 8 \%$. See Figure S12 for NMR spectrum of the crude product.

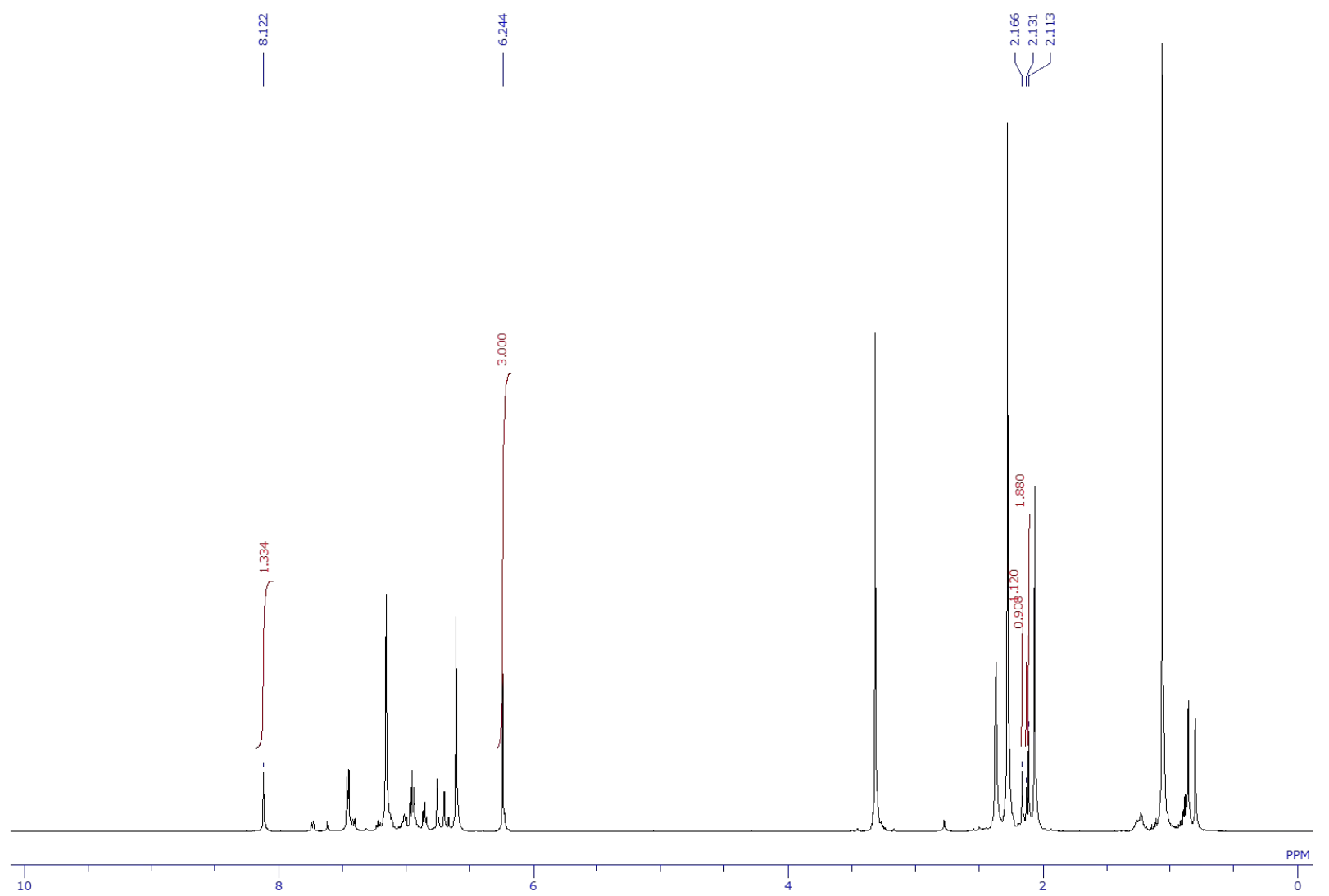

Figure S12. The ${ }^{1} \mathrm{H}$ NMR spectrum of the reaction mixture in run 11, Table 1 (2.13 ppm: 1; 8.12 ppm: 2 c; 2.16 ppm: 2b; 2.11 ppm: 2a; 6.23 ppm: internal standard, 1,3,5-trimethoxybenzene) 


\section{Conditions and results for run 13}

Toluene $(1.00 \mathrm{~mL}), 1(75.2 \mathrm{mg}, 0.200 \mathrm{mmol})$, phenylacetylene $(24.0 \mu \mathrm{L}, 0.220 \mathrm{mmol}),{ }^{n} \mathrm{BuLi}(0.100 \mathrm{M}$ diluted in toluene, $20.0 \mu \mathrm{L}, 2.00 \mu \mathrm{mol})$, DME $(0.100 \mathrm{M}$ diluted in toluene, $20.0 \mu \mathrm{L}, 2.00 \mu \mathrm{mol}), 100{ }^{\circ} \mathrm{C}, 1 \mathrm{~h}$, trimethoxybenzene $(18.2 \mathrm{mg}, 0.108 \mathrm{mmol})$ crude $(104.3 \mathrm{mg})$; NMR yield: $\mathbf{2 a}, 23 \%$; $2 \mathbf{b}, 13 \%$; $\mathbf{2 c}, 44 \%$; 1, $18 \%$. See Figure S13 for NMR spectrum of the crude product.

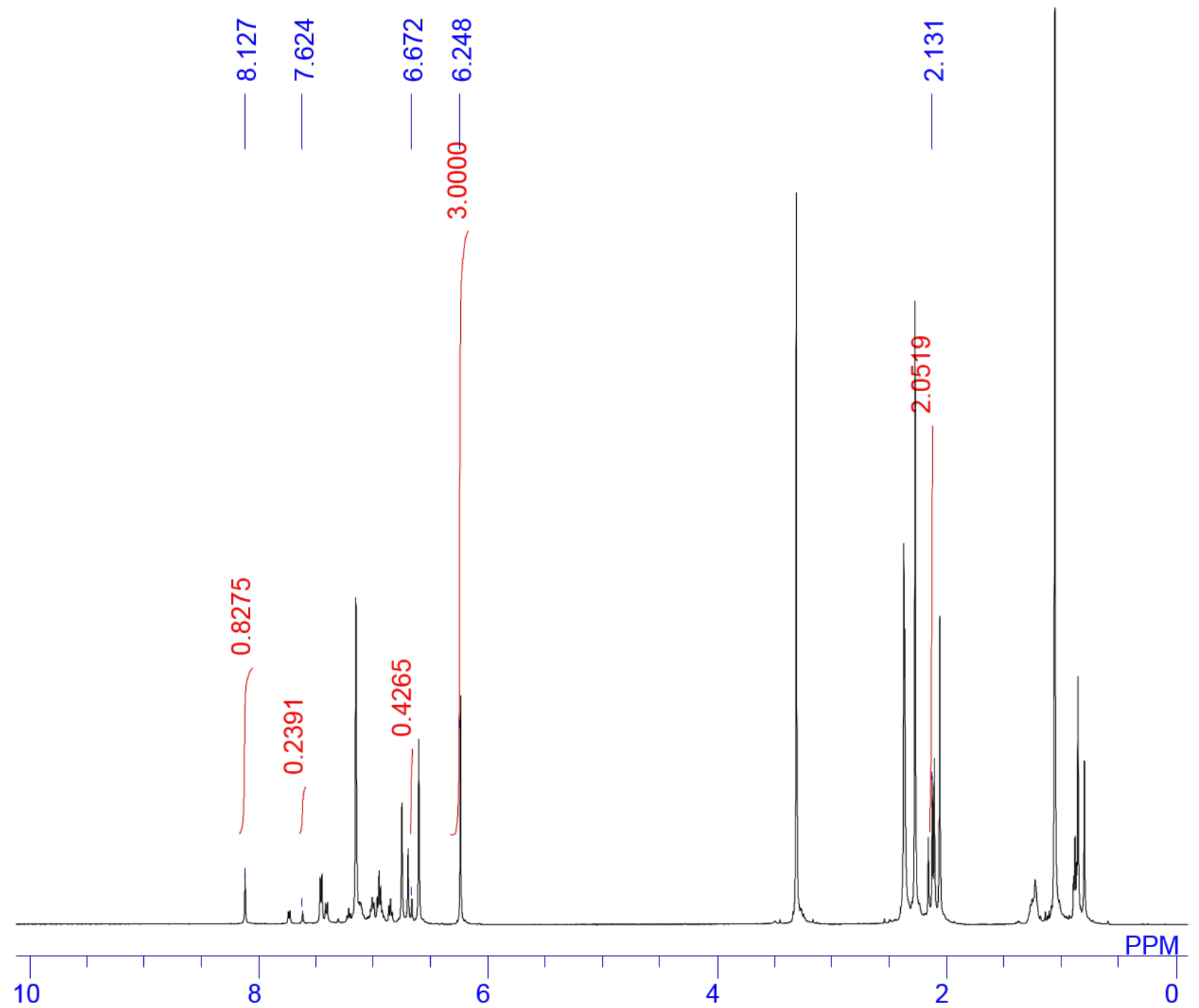

Figure S13. The ${ }^{1} \mathrm{H}$ NMR spectrum of the reaction mixture in run 12, Table 1 (2.13 ppm: 1; 8.13 ppm: 2 c; 7.62 ppm: $\mathbf{2 b}$; 6.67 ppm: $\mathbf{2 a} ; 6.23$ ppm: internal standard, 1,3,5-trimethoxybenzene)

\section{Isolation of 2a under the conditions of Table 1, run 1}

In a glovebox, to a toluene solution $(2.00 \mathrm{~mL})$ of $1(226 \mathrm{mg}, 0.600 \mathrm{mmol})$ in a $10 \mathrm{~mL}$ J-young tube, phenylacetylene $(30.0 \mu \mathrm{L}, 0.660 \mathrm{mmol})$ was added. After the reaction mixture stirred at $100{ }^{\circ} \mathrm{C}$ for $37 \mathrm{~h}$, volatiles were removed from the pale green solution in vacuo. Purification of the residue by recrystallization with hexane/toluene (10/1) afforded colorless crystals of $2 \mathrm{a}(121 \mathrm{mg}, 0.253 \mathrm{mmol}, 42 \%) .{ }^{1} \mathrm{H}$ NMR $\left(500 \mathrm{MHz}, \mathrm{C}_{6} \mathrm{D}_{6}\right) \delta$ $0.86\left(\mathrm{~s}, 12 \mathrm{H}\right.$, pin- $\left.\mathrm{CH}_{3}\right), 2.11$ (s, $\left.6 \mathrm{H}, p-\mathrm{CH}_{3}\right), 2.38\left(\mathrm{br} \mathrm{s}, 12 \mathrm{H}, o-\mathrm{CH}_{3}\right), 6.68(\mathrm{~s}, 1 \mathrm{H}, \mathrm{CH}), 6.71(\mathrm{~s}, 4 \mathrm{H}, \mathrm{ArH}$ of Mes), $6.93(\mathrm{t}, J=7 \mathrm{~Hz}, 1 \mathrm{H}, \mathrm{ArH}$ of $\mathrm{Ph}), 7.02\left(\mathrm{t}, J=7 \mathrm{~Hz}, 2 \mathrm{H}, \mathrm{ArH}\right.$ of Ph), $7.42\left(\mathrm{~d}, J=7 \mathrm{~Hz}, 2 \mathrm{H}, \mathrm{ArH}\right.$ of Ph); ${ }^{11} \mathrm{~B}$ NMR $\left(161 \mathrm{MHz}, \mathrm{C}_{6} \mathrm{D}_{6}\right) \delta 29$ (br s), 76 (br s); ${ }^{13} \mathrm{C}$ NMR $\left(126 \mathrm{MHz}, \mathrm{C}_{6} \mathrm{D}_{6}\right) \delta 21.3\left(\mathrm{CH}_{3}\right), 24.0\left(\mathrm{CH}_{3}\right), 24.6\left(\mathrm{CH}_{3}\right), 83.2\left(4^{\circ}\right)$, 
127.3 (CH), $127.8(\mathrm{CH}), 128.4(\mathrm{CH}), 129.0(\mathrm{CH}), 133.3\left(\mathrm{br}, \mathrm{CH}\right.$, bonding to the B nucleus), $139.4\left(4^{\circ}\right), 141.9$ (br, $4^{\circ}$, bonding to the B nucleus), $144.0\left(4^{\circ}\right), 145.6\left(4^{\circ}\right), 170.9$ (br, $4^{\circ}$, bonding to the B nucleus); mp $136-138^{\circ} \mathrm{C}$; Anal. Calcd for $\mathrm{C}_{32} \mathrm{H}_{40} \mathrm{~B}_{2} \mathrm{O}_{2}$ : C, 80.36; $\mathrm{H}, 8.43$. Found: $\mathrm{C}, 80.36$ (coincidentally matched to the calculated value); $\mathrm{H}, 8.53$.

\section{Isolation of $2 \mathrm{~b}$ under the conditions of Table 1 , run 2}

In a glovebox, to a solution of phenylacetylene $(60.5 \mu \mathrm{L}, 0.550 \mathrm{mmol})$ in toluene $(2.5 \mathrm{~mL}),{ }^{n} \mathrm{BuLi}$ in hexane $(2.69$ $\mathrm{M}, 27.9 \mu \mathrm{L}, 0.075 \mathrm{mmol}$ ) was added dropwise at room temperature. After stirring the reaction mixture at room temperature for $3 \mathrm{~min}, \mathbf{1}$ (188 $\mathrm{mg}, 0.500 \mathrm{mmol})$ was added to the reaction mixture at room temperature. After the reaction mixture stirred at $100{ }^{\circ} \mathrm{C}$ for $17 \mathrm{~h}$, volatiles were removed from the pale orange solution in vacuo. The residue was triturated with hexane and the resulting suspension was filtered through a pad of Celite. After the removal of volatiles from the filtrate, the resulting oil was purified by recycling GPC ( 25 cycles) to give pure $\mathbf{2 b}$ as a pale yellow oil (114 $\mathrm{mg}, 0.237 \mathrm{mmol}, 47 \%)$. Single crystals of $\mathbf{2 b}$ suitable for X-ray diffraction analysis were obtained by recrystallization from its hexane solution. ${ }^{1} \mathrm{H}$ NMR $\left(500 \mathrm{MHz}, \mathrm{C}_{6} \mathrm{D}_{6}\right) \delta 0.81\left(\mathrm{~s}, 12 \mathrm{H}\right.$, pin- $\left.\mathrm{CH}_{3}\right), 2.17$ (s, $\left.6 \mathrm{H}, p-\mathrm{CH}_{3}\right), 2.38\left(\mathrm{~s}, 12 \mathrm{H}, o-\mathrm{CH}_{3}\right), 6.76(\mathrm{~s}, 4 \mathrm{H}, \mathrm{ArH}$ of Mes), $7.11(\mathrm{t}, J=7 \mathrm{~Hz}, 1 \mathrm{H}, \mathrm{ArH}$ of Ph), $7.22(\mathrm{t}, J=7$ $\mathrm{Hz}, 2 \mathrm{H}, \mathrm{ArH}$ of Ph), $7.62(\mathrm{~s}, 1 \mathrm{H}, \mathrm{CH}), 7.75$ (d, $J=8 \mathrm{~Hz}, 2 \mathrm{H}, \mathrm{ArH}$ of Ph); ${ }^{11} \mathrm{~B}$ NMR (161 MHz, $\left.\mathrm{C}_{6} \mathrm{D}_{6}\right) \delta 31$ (br s), 76 (br s); ${ }^{13} \mathrm{C}$ NMR (126 MHz, $\left.\mathrm{C}_{6} \mathrm{D}_{6}\right) \delta 21.4\left(\mathrm{CH}_{3}\right), 24.0\left(\mathrm{CH}_{3}\right), 24.7\left(\mathrm{CH}_{3}\right), 83.7\left(4^{\circ}\right), 127.5(\mathrm{CH}), 127.7(\mathrm{CH})$, $128.7(\mathrm{CH}), 128.9(\mathrm{CH}), 139.0\left(4^{\circ}\right), 141.3\left(4^{\circ}\right), 143.3\left(\mathrm{br}, 4^{\circ}\right.$, bonding to the B nucleus), $144.9\left(4^{\circ}\right), 149.3\left(\mathrm{br}, 4^{\circ}\right.$, bonding to the $\mathrm{B}$ nucleus), 154.2 (br, $4^{\circ}$, bonding to the $\mathrm{B}$ nucleus); mp $108-110{ }^{\circ} \mathrm{C}$; Anal. Calcd for $\mathrm{C}_{32} \mathrm{H}_{40} \mathrm{~B}_{2} \mathrm{O}_{2}$ : C, 80.36; H, 8.43. Found: C, 80.24; H, 8.54.

\section{Isolation of $2 \mathrm{c}$ under the conditions of Table 1, run 10}

In a glovebox, to a solution of phenylacetylene $(121 \mu \mathrm{L}, 1.10 \mathrm{mmol})$ in toluene $(5.00 \mathrm{~mL}),{ }^{n} \mathrm{BuLi}$ in hexane $(2.69$ $\mathrm{M}, 58.0 \mu \mathrm{L}, 0.156 \mathrm{mmol}$ ) was added dropwise at room temperature. After stirring the reaction mixture at room temperature for $3 \mathrm{~min}, 1$ (376 $\mathrm{mg}, 1.00 \mathrm{mmol})$ and DME (65.5 $\mu \mathrm{L}, 1.0 \mathrm{mmol})$ were added to the reaction mixture at room temperature. After the reaction mixture stirred at $100{ }^{\circ} \mathrm{C}$ for $1 \mathrm{~h}$, volatiles were removed from the pale yellow solution in vacuo. The residue was triturated with hexane and the resulting suspension was filtered through a pad of Celite. After volatiles were removed from the filtrate in vacuo, the residue was recrystallized by slow evaporation of its hexane solution to the coexistent silica-gel in a capped vial at room temperature afforded yellow crystals of $2 \mathrm{c}(221 \mathrm{mg}, 0.463 \mathrm{mmol}, 46 \%) .{ }^{1} \mathrm{H}$ NMR $\left(500 \mathrm{MHz}, \mathrm{C}_{6} \mathrm{D}_{6}\right) \delta 1.06\left(\mathrm{~s}, 12 \mathrm{H}\right.$, pin- $\left.\mathrm{CH}_{3}\right), 2.07(\mathrm{~s}, 6 \mathrm{H}$, $\left.p-\mathrm{CH}_{3}\right), 2.29\left(\mathrm{~s}, 12 \mathrm{H}, o-\mathrm{CH}_{3}\right), 6.61(\mathrm{~s}, 4 \mathrm{H}, \mathrm{ArH}$ of Mes), $6.86(\mathrm{t}, J=7 \mathrm{~Hz}, 1 \mathrm{H}, \mathrm{ArH}$ of Ph), $6.96(\mathrm{t}, J=7 \mathrm{~Hz}, 2 \mathrm{H}$, ArH of Ph), 7.47 (d, $J=8 \mathrm{~Hz}, 2 \mathrm{H}, \mathrm{ArH}$ of $\mathrm{Ph}$ ), 8.14 (s, 1H, CH); ${ }^{11} \mathrm{~B}$ NMR (161 MHz, $\left.\mathrm{C}_{6} \mathrm{D}_{6}\right) \delta 30$ (br s), 77 (br s); ${ }^{13} \mathrm{C}$ NMR (126 MHz, $\left.\mathrm{C}_{6} \mathrm{D}_{6}\right)$ \& $21.2\left(\mathrm{CH}_{3}\right), 23.8\left(\mathrm{CH}_{3}\right), 24.9\left(\mathrm{CH}_{3}\right), 83.9\left(4^{\circ}\right), 126.8(\mathrm{CH}), 127.2(\mathrm{CH}), 128.6(\mathrm{CH})$, $128.8(\mathrm{CH}), 138.7\left(4^{\circ}\right), 140.3\left(4^{\circ}\right), 142.8\left(4^{\circ}\right), 143.1\left(\mathrm{br}, 4^{\circ}\right.$, bonding to the B nucleus), 151.0 (br, $4^{\circ}$, bonding to the B nucleus), 156.7 (br, $\mathrm{CH}$, bonding to the B nucleus); mp 140-142 ${ }^{\circ} \mathrm{C}$ (decomp.); Anal. Calcd for $\mathrm{C}_{32} \mathrm{H}_{40} \mathrm{~B}_{2} \mathrm{O}_{2}$ : C, 80.36; H, 8.43. Found: C, 80.34; H, 8.55. 


\section{Substrate scope of diboration reaction (Table 2)}

\section{Direct reaction of 1 with 4-bromophenylacetylene (Table 2, run 1)}

In a glovebox, to a toluene solution $(1.25 \mathrm{~mL})$ of $\mathbf{1}(188 \mathrm{mg}, 0.500 \mathrm{mmol})$ in a $10 \mathrm{~mL} \mathrm{~J}$-young tube, 4-bromophenyl-acetylene $(99.8 \mathrm{mg}, 0.550 \mathrm{mmol})$ was added. After stirring reaction mixture at $100{ }^{\circ} \mathrm{C}$ for $23 \mathrm{~h}$, volatiles were removed from the reaction mixture in vacuo. Purification of the residue by recycling GPC (21 cycles) afforded clear oils of 3Aa (164 mg, $0.295 \mathrm{mmol}, 59 \%)$ and 3Ab (67.4 mg, $0.121 \mathrm{mmol}$, 24\%). Single crystals of 3Aa suitable for X-ray diffraction analysis were obtained by recrystallization from its hexane solution. 3Aa: ${ }^{1} \mathrm{H}$ NMR $\left(400 \mathrm{MHz}, \mathrm{CDCl}_{3}\right) \delta$ 0.93(s, 12H, pin- $\left.\mathrm{CH}_{3}\right), 2.11$ (brs, $\left.12 \mathrm{H}, o-\mathrm{CH}_{3}\right), 2.23\left(\mathrm{~s}, 6 \mathrm{H}, o-\mathrm{CH}_{3}\right), 6.28(\mathrm{~s}$, 1H, CH), 6.70 (s, 4H, ArH of Mes), 7.06 (d, $J=9 \mathrm{~Hz}, 2 \mathrm{H}, \mathrm{ArH}), 7.28(\mathrm{~d}, J=9 \mathrm{~Hz}, 2 \mathrm{H}, \mathrm{ArH}) ;{ }^{11} \mathrm{~B} \mathrm{NMR}(128 \mathrm{MHz}$, $\left.\mathrm{CDCl}_{3}\right) \delta 31$ (br s), 79 (br s); ${ }^{13} \mathrm{C} \mathrm{NMR}\left(101 \mathrm{MHz}, \mathrm{C}_{6} \mathrm{D}_{6}\right) \delta 21.3\left(\mathrm{CH}_{3}\right), 23.7\left(\mathrm{CH}_{3}\right), 24.4\left(\mathrm{CH}_{3}\right), 83.4\left(4^{\circ}\right)$, 121.2(4 $\left.4^{\circ}\right), 128.5(\mathrm{CH}), 129.1(\mathrm{CH}), 131.2(\mathrm{CH}), 132.7\left(\mathrm{br}, \mathrm{CH}\right.$, bonding to the $\mathrm{B}$ nucleus), $139.4\left(4^{\circ}\right), 141.6(\mathrm{br}$, $\left.4^{\circ}\right), 143.1$ (br, $4^{\circ}$, bonding to the B nucleus), $144.1\left(4^{\circ}\right), 169.4$ (br, $4^{\circ}$, bonding to the B nucleus); HRMS (ESI+) Calcd for $\mathrm{C}_{32} \mathrm{H}_{39} \mathrm{~B}_{2}{ }^{79} \mathrm{BrO}_{2}$ and $\mathrm{C}_{32} \mathrm{H}_{39} \mathrm{~B}_{2}{ }^{81} \mathrm{BrO}_{2}\left[\mathrm{M}^{+}\right]$: 556.2320, 558.2299, found: 556.2333, 558.2293; 3Ab: ${ }^{1} \mathrm{H}$ NMR (400 MHz, $\left.\mathrm{C}_{6} \mathrm{D}_{6}\right) \delta 0.78\left(\mathrm{~s}, 12 \mathrm{H}, \mathrm{pin}-\mathrm{CH}_{3}\right), 2.17\left(\mathrm{~s}, 12 \mathrm{H}, o-\mathrm{CH}_{3}\right), 2.35\left(\mathrm{~s}, 6 \mathrm{H}, o-\mathrm{CH}_{3}\right), 6.76(\mathrm{~s}, 4 \mathrm{H}, \mathrm{ArH}$ of Mes), $7.33(\mathrm{~d}, J=9 \mathrm{~Hz}, 2 \mathrm{H}, \mathrm{ArH}), 7.41$ (d, $J=9 \mathrm{~Hz}, 2 \mathrm{H}, \mathrm{ArH}), 7.49$ (s, 1H, CH); HRMS (ESI+) Calcd for $\mathrm{C}_{32} \mathrm{H}_{39} \mathrm{~B}_{2}{ }^{79} \mathrm{BrO}_{2}$ and $\mathrm{C}_{32} \mathrm{H}_{39} \mathrm{~B}_{2}{ }^{81} \mathrm{BrO}_{2}\left[\mathrm{M}^{+}\right]$: 556.2320, 558.2299, found: 556.2317, 558.2316.

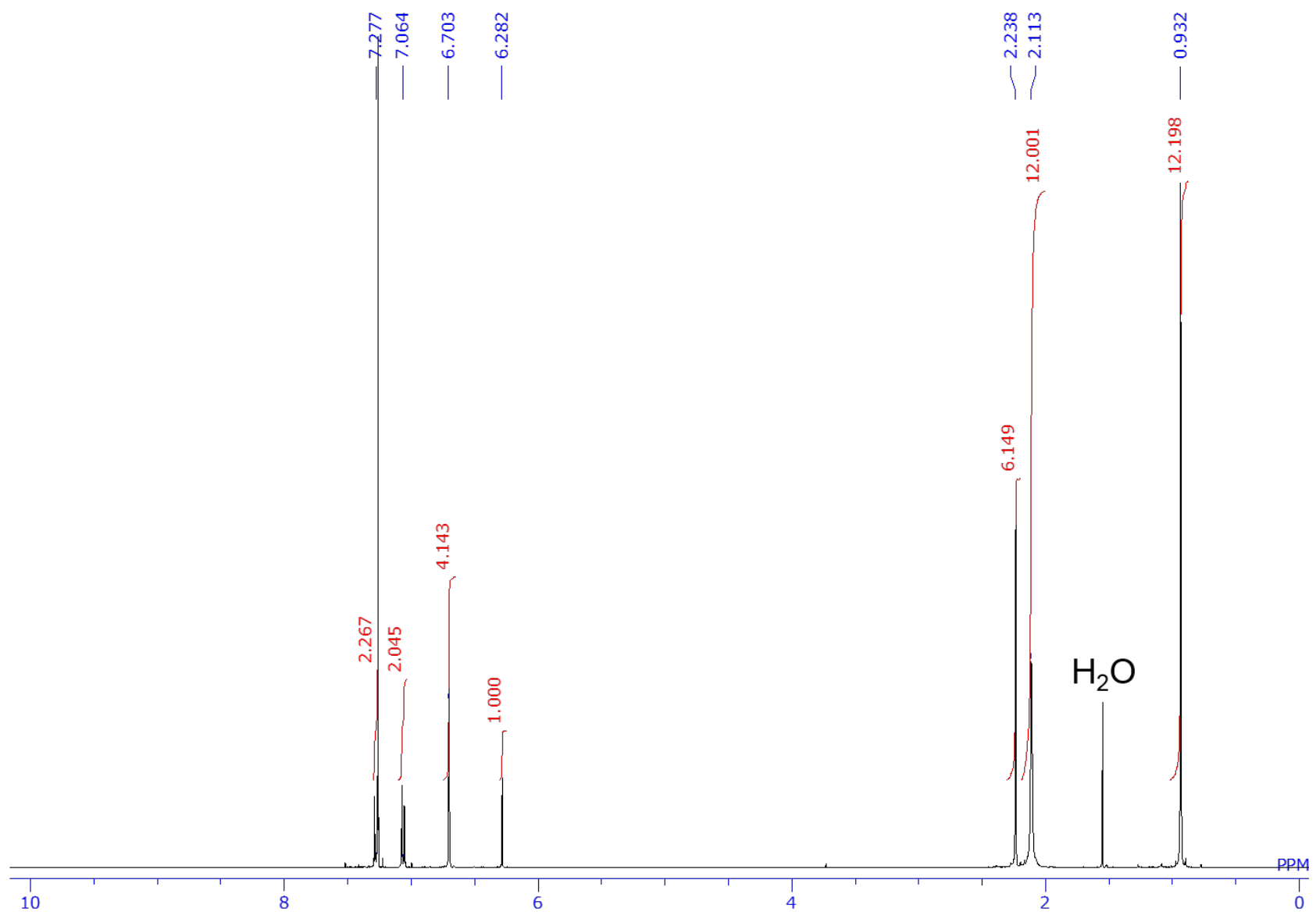

Figure S14. The ${ }^{1} \mathrm{H}$ NMR spectrum $\left(\mathrm{CDCl}_{3}\right)$ of $\mathbf{3 A a}$ 


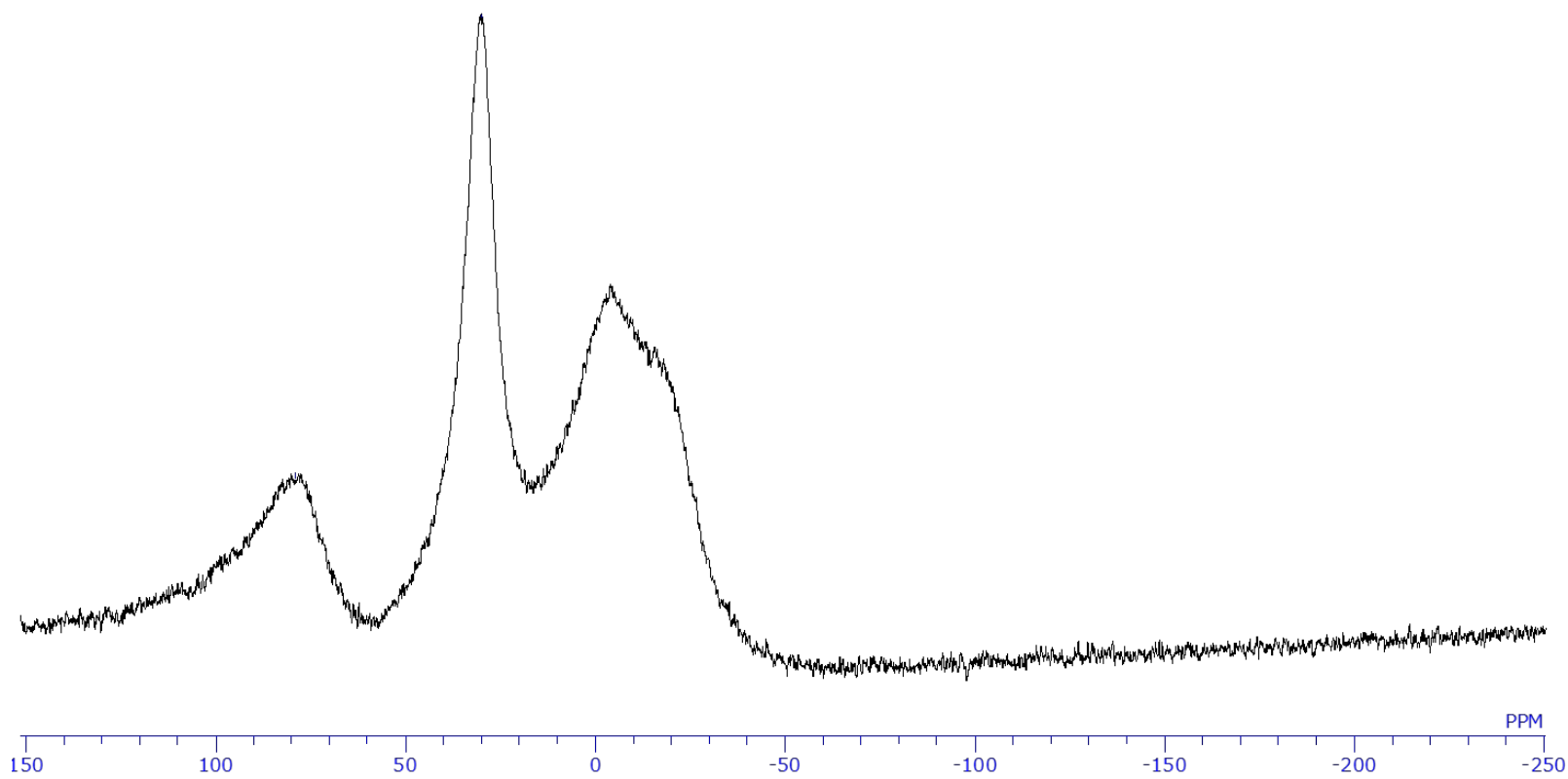

Figure S15. The ${ }^{11} \mathrm{~B}$ NMR spectrum (borosilicate NMR tube, $\mathrm{CDCl}_{3}$ ) of $\mathbf{3 A a}$

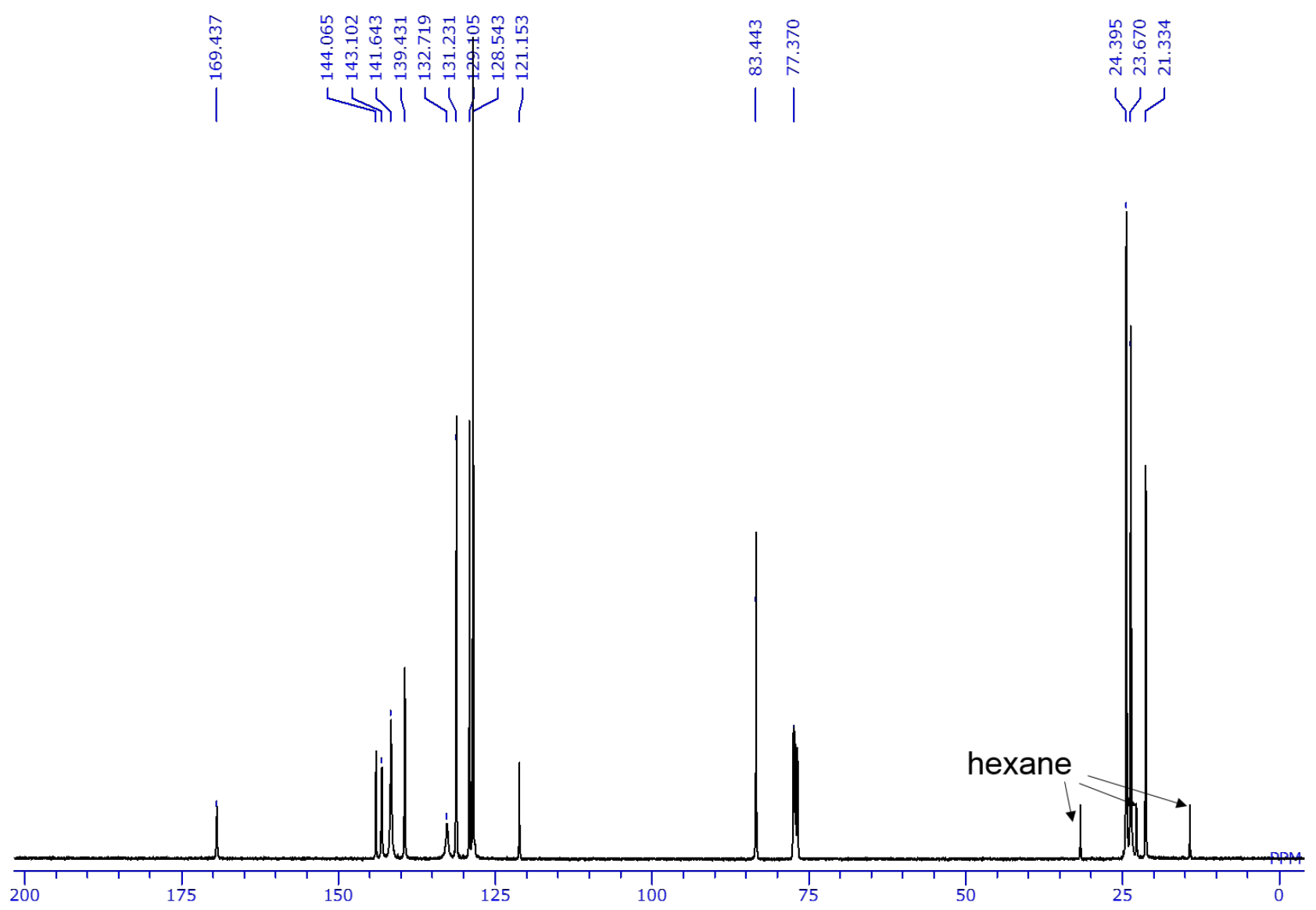

Figure S16. The ${ }^{13} \mathrm{C}$ NMR spectrum $\left(\mathrm{CDCl}_{3}\right)$ of $\mathbf{3 A a}$ 


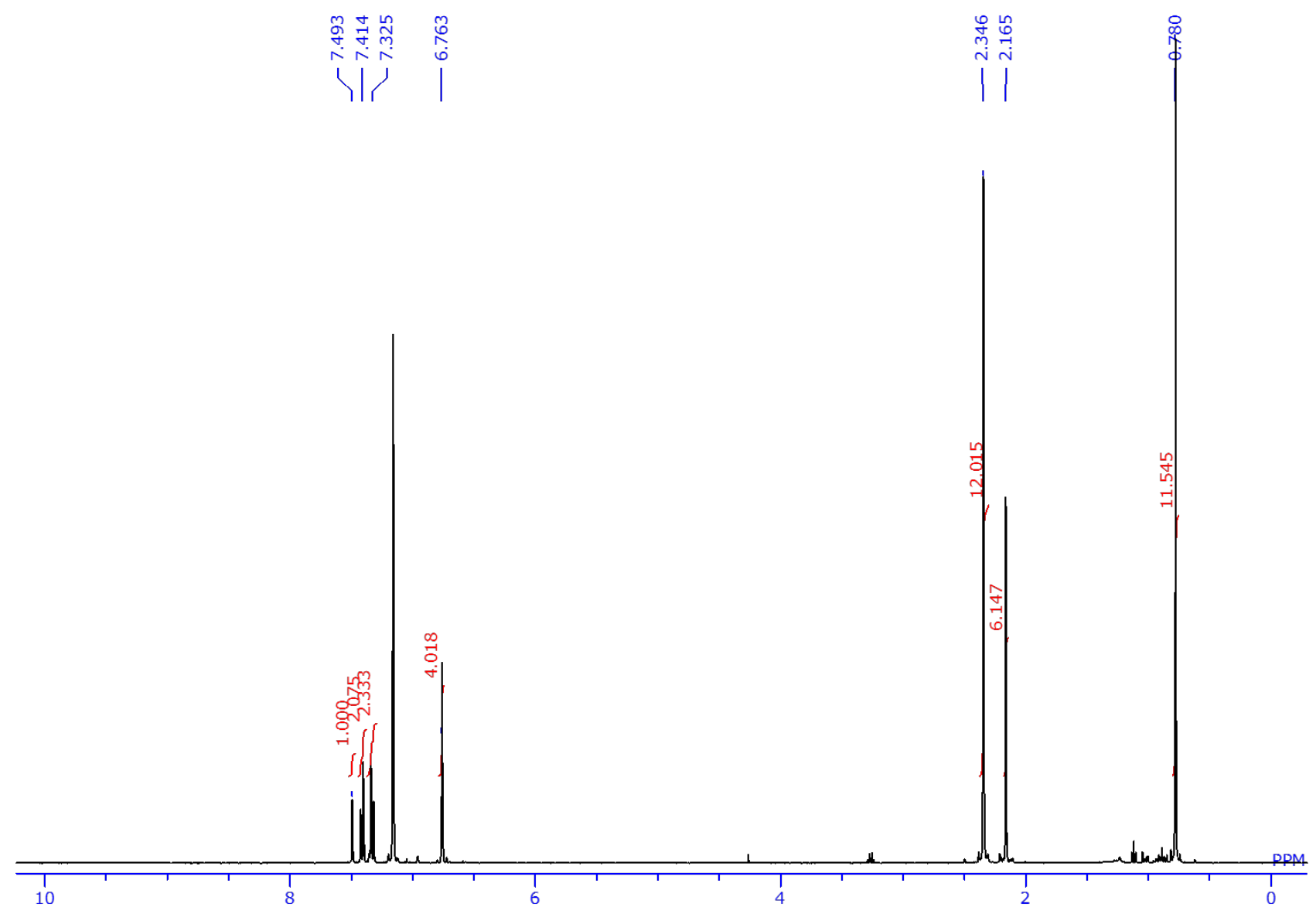

Figure S17. The ${ }^{1} \mathrm{H}$ NMR spectrum $\left(\mathrm{CDCl}_{3}\right)$ of $\mathbf{3} \mathbf{A b}$

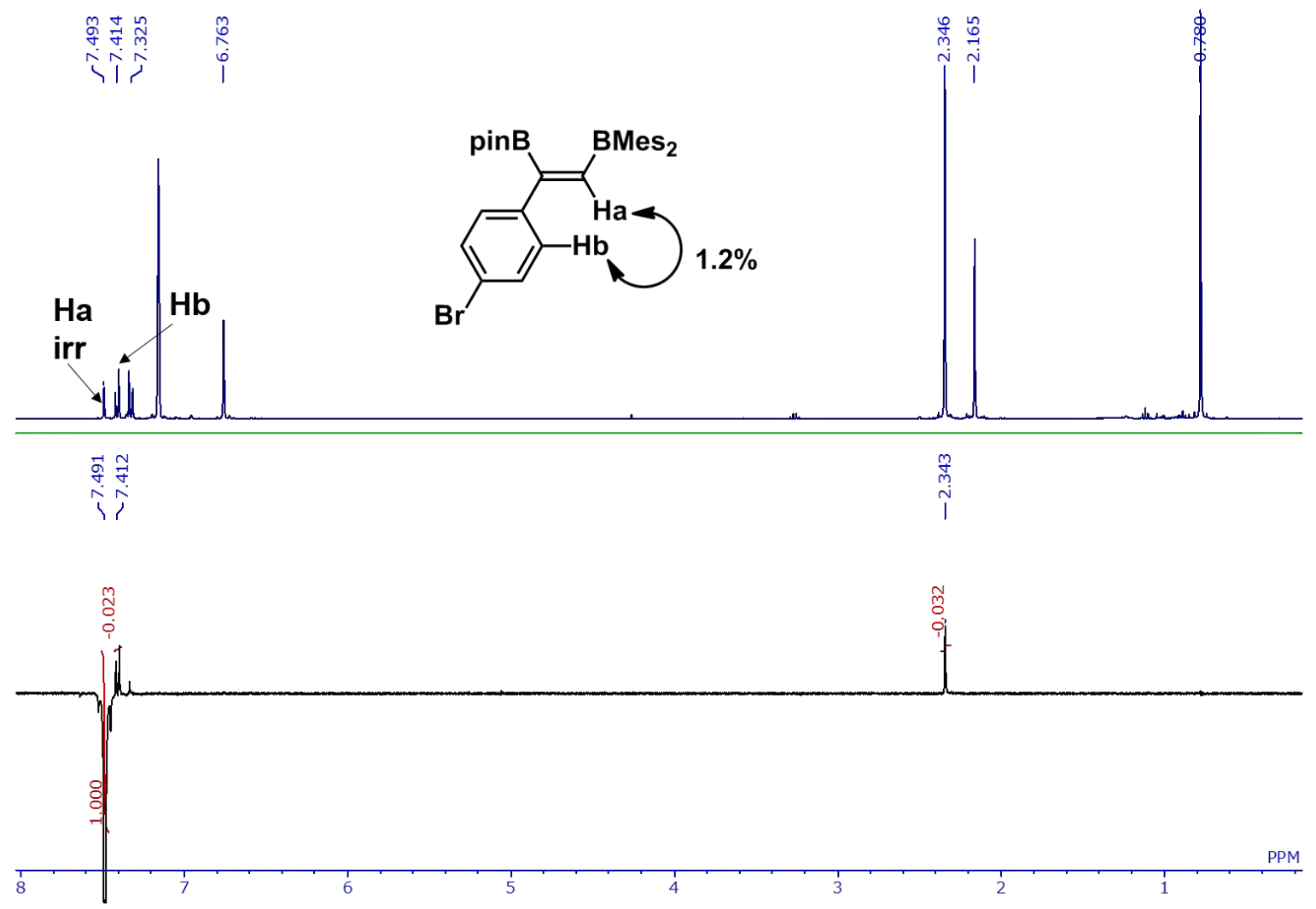

Figure S18. The differential ${ }^{1} \mathrm{H}$ NOE spectrum $\left(\mathrm{CDCl}_{3}\right)$ of $\mathbf{3 A b}$ with irradiation to the signal of vinylic $\mathrm{H}_{\mathrm{a}}$ 


\section{NMR yield of $3 \mathrm{Aa}$ and $3 \mathrm{Ab}$ in run 1 , Table 2}

The procedure described in run 1, Table 1 was used. Reaction condition: Toluene (500 $\mu \mathrm{L}), 1$ (75.2 mg, 0.200 mmol), 4-bromophenyl-acetylene $(39.8 \mathrm{mg}, 0.220 \mathrm{mmol}), 100{ }^{\circ} \mathrm{C}, 23 \mathrm{~h}$, trimethoxybenzene $(17.9 \mathrm{mg}, 0.107$ mmol), crude (119 mg); NMR yield: 3Aa, 64\%; 3Ab, 26\%. See Figure S19 for NMR spectrum of the crude product.

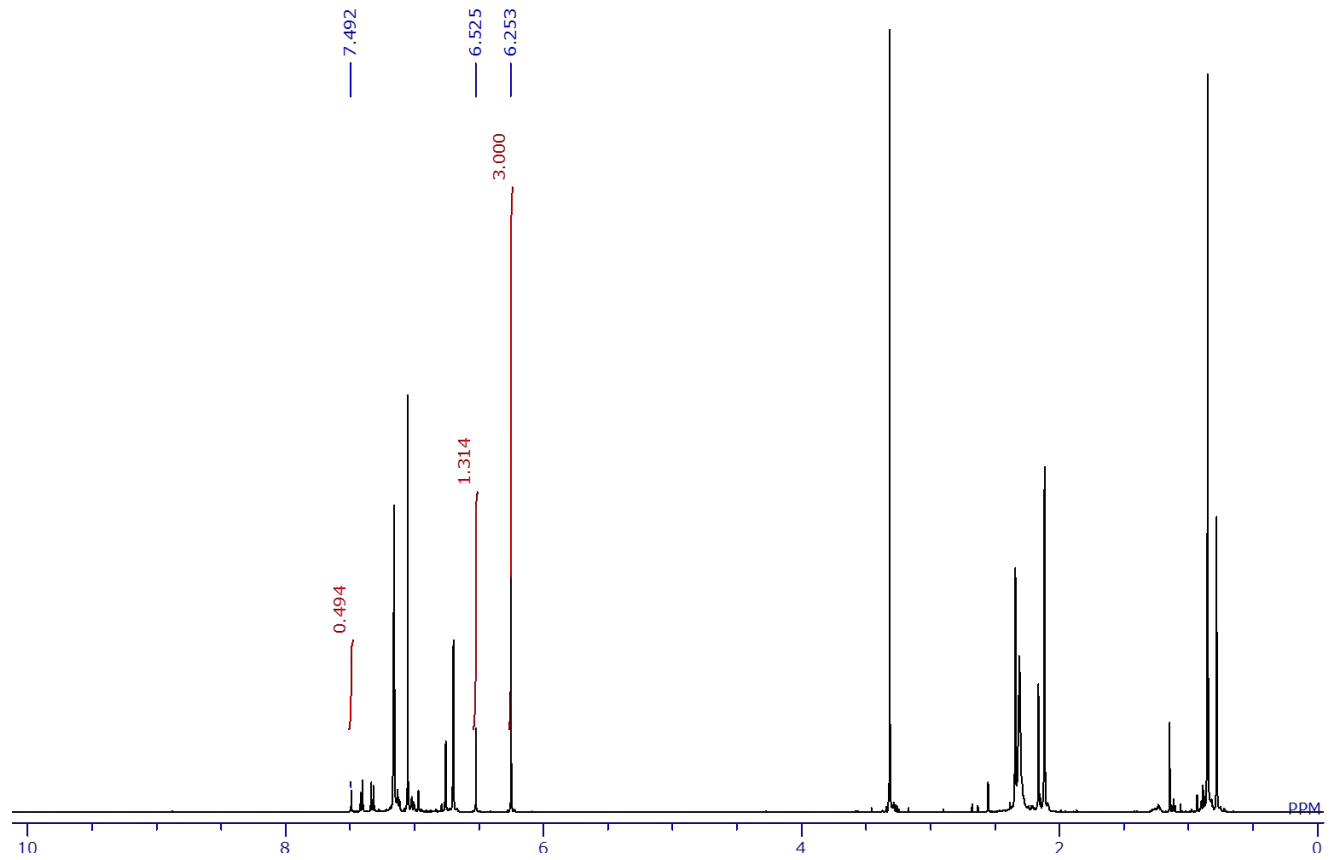

Figure S19. The ${ }^{1} \mathrm{H}$ NMR spectrum of the reaction mixture in run 1, Table 2 (6.53 ppm: 3Aa; 7.49 ppm: 3Ab; 6.25 ppm: internal standard, 1,3,5-trimethoxybenzene) 


\section{Base-catalyzed reaction of 1 with 4-bromophenylacetylene (Table 2, run 2)}

In a glovebox, to a solution of 4-bromophenyl-acetylene $(100 \mathrm{mg}, 0.552 \mathrm{mmol})$ in toluene $(1.25 \mathrm{~mL}),{ }^{n} \mathrm{BuLi}$ $(0.100 \mathrm{M}$ diluted in toluene, $150 \mu \mathrm{L}, 150 \mu \mathrm{mol})$ was added dropwise at room temperature. After stirring the reaction mixture at room temperature for $3 \mathrm{~min}, 1(188.9 \mathrm{mg}, 0.502 \mathrm{mmol})$ and DME $(0.100 \mathrm{M}$ diluted in toluene, $150 \mu \mathrm{L}, 150 \mu \mathrm{mol})$ were added to the reaction mixture at room temperature. After the reaction mixture stirred at $100{ }^{\circ} \mathrm{C}$ for $3 \mathrm{~h}$, volatiles were removed from the pale yellow solution in vacuo. The residue was triturated with hexane and the resulting suspension was filtered through a pad of Celite. After volatiles were removed from the filtrate in vacuo, the residue were purified by recycling GPC ( 8 cycles) afforded yellow oil of 3Ac (100 mg, 0.179 mmol, 35\%). Single crystals of 3Ac suitable for X-ray diffraction analysis were obtained by slow evaporation of its hexane solution to the coexistent silica-gel in a capped vial at room temperature. ${ }^{1} \mathrm{H}$ NMR $\left(400 \mathrm{MHz}, \mathrm{C}_{6} \mathrm{D}_{6}\right) \delta$ 1.05(s, $12 \mathrm{H}$, pin- $\left.\mathrm{CH}_{3}\right), 2.10\left(\mathrm{~s}, 6 \mathrm{H}, o-\mathrm{CH}_{3}\right), 2.21\left(\mathrm{brs}, 12 \mathrm{H}, o-\mathrm{CH}_{3}\right), 6.59$ (s, 4H, ArH of Mes), 7.05 (d, $J=9 \mathrm{~Hz}$, $2 \mathrm{H}, \mathrm{ArH}), 7.13(\mathrm{~d}, J=9 \mathrm{~Hz}, 2 \mathrm{H}, \mathrm{ArH}), 8.10(\mathrm{~s}, 1 \mathrm{H}, \mathrm{CH}) ;{ }^{11} \mathrm{~B} \mathrm{NMR}\left(128 \mathrm{MHz}, \mathrm{CD}_{2} \mathrm{Cl}_{2}\right) \delta 30$ (br s), 73 (br s); ${ }^{13} \mathrm{C}$ NMR (101 MHz, $\left.\mathrm{CD}_{2} \mathrm{Cl}_{2}\right) \delta 21.3\left(\mathrm{CH}_{3}\right), 23.5\left(\mathrm{CH}_{3}\right), 25.0\left(\mathrm{CH}_{3}\right), 84.5\left(4^{\circ}\right), 120.8\left(4^{\circ}\right), 128.6(\mathrm{CH}), 129.9(\mathrm{CH})$, $130.1(\mathrm{CH}), 139.4\left(4^{\circ}\right), 140.3\left(4^{\circ}\right), 141.6\left(4^{\circ}\right), 142.7\left(\mathrm{br}, 4^{\circ}\right.$, bonding to the B nucleus), $149.7\left(\mathrm{br}, 4^{\circ}\right.$, bonding to the B nucleus), 156.7 (br, $4^{\circ}$, bonding to the B nucleus); mp 168-170 ${ }^{\circ} \mathrm{C}$; HRMS (ESI+) Calcd for $\mathrm{C}_{32} \mathrm{H}_{39} \mathrm{~B}_{2}{ }^{79} \mathrm{BrO}_{2}$ and $\mathrm{C}_{32} \mathrm{H}_{39} \mathrm{~B}_{2}{ }^{81} \mathrm{BrO}_{2}\left[\mathrm{M}^{+}\right]$: 556.2320, 558.2299, found: 556.2320, 558.2299.
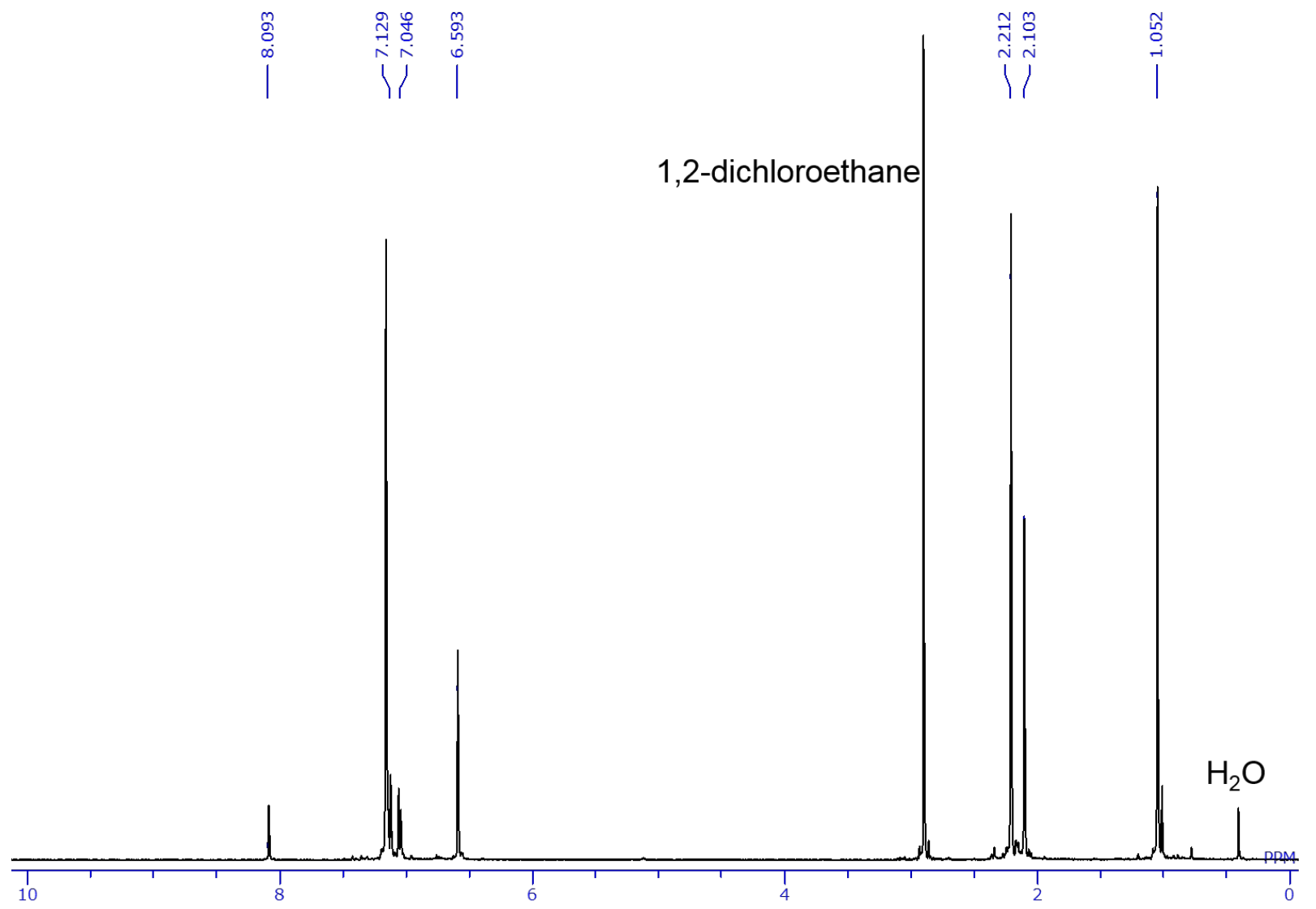

Figure S20. The ${ }^{1} \mathrm{H}$ NMR spectrum $\left(\mathrm{C}_{6} \mathrm{D}_{6}\right)$ of $\mathbf{3 A c}$ 


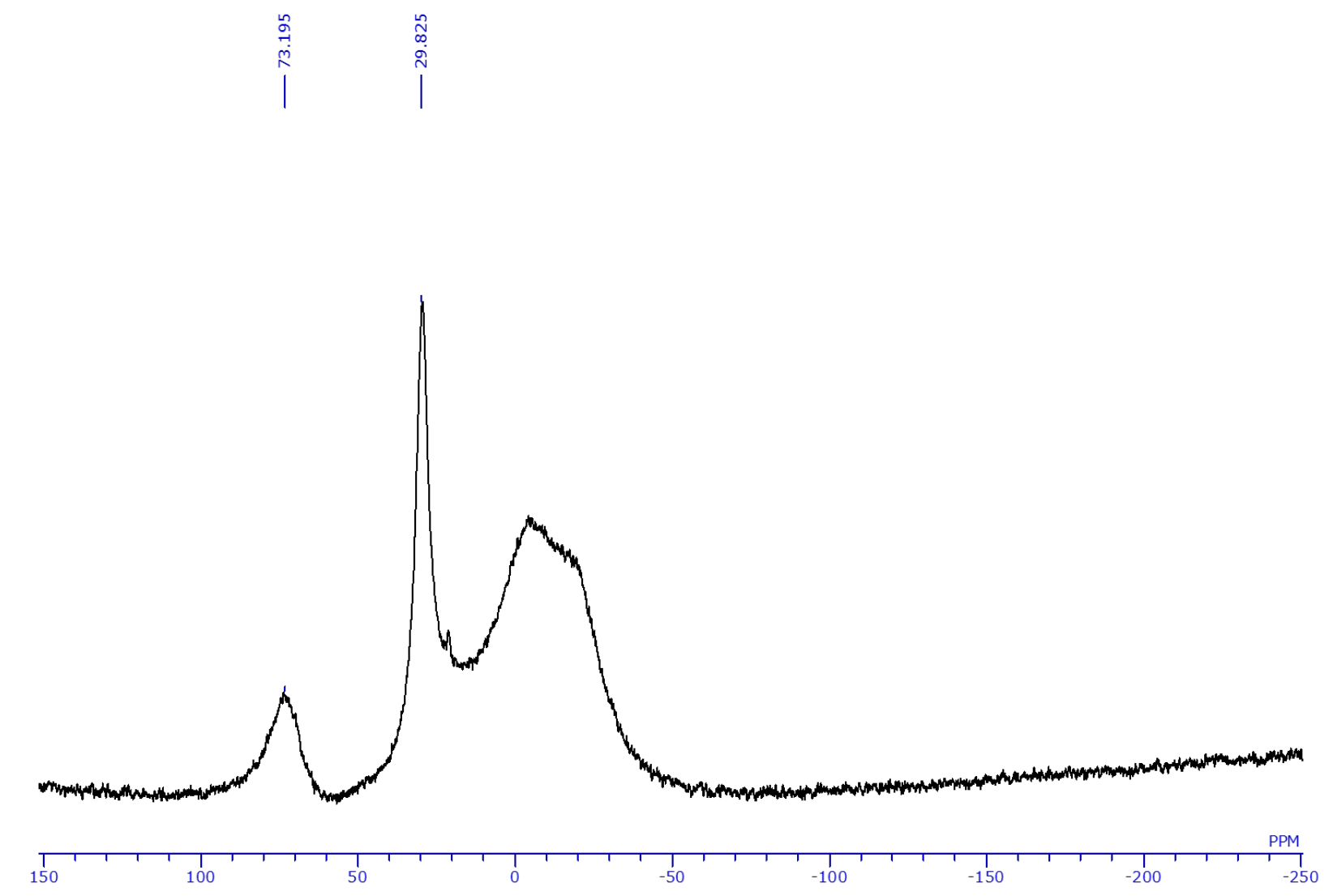

Figure S21. The ${ }^{11} \mathrm{~B}$ NMR spectrum (borosilicate NMR tube, $\mathrm{CD}_{2} \mathrm{Cl}_{2}$ ) of $\mathbf{3 A c}$

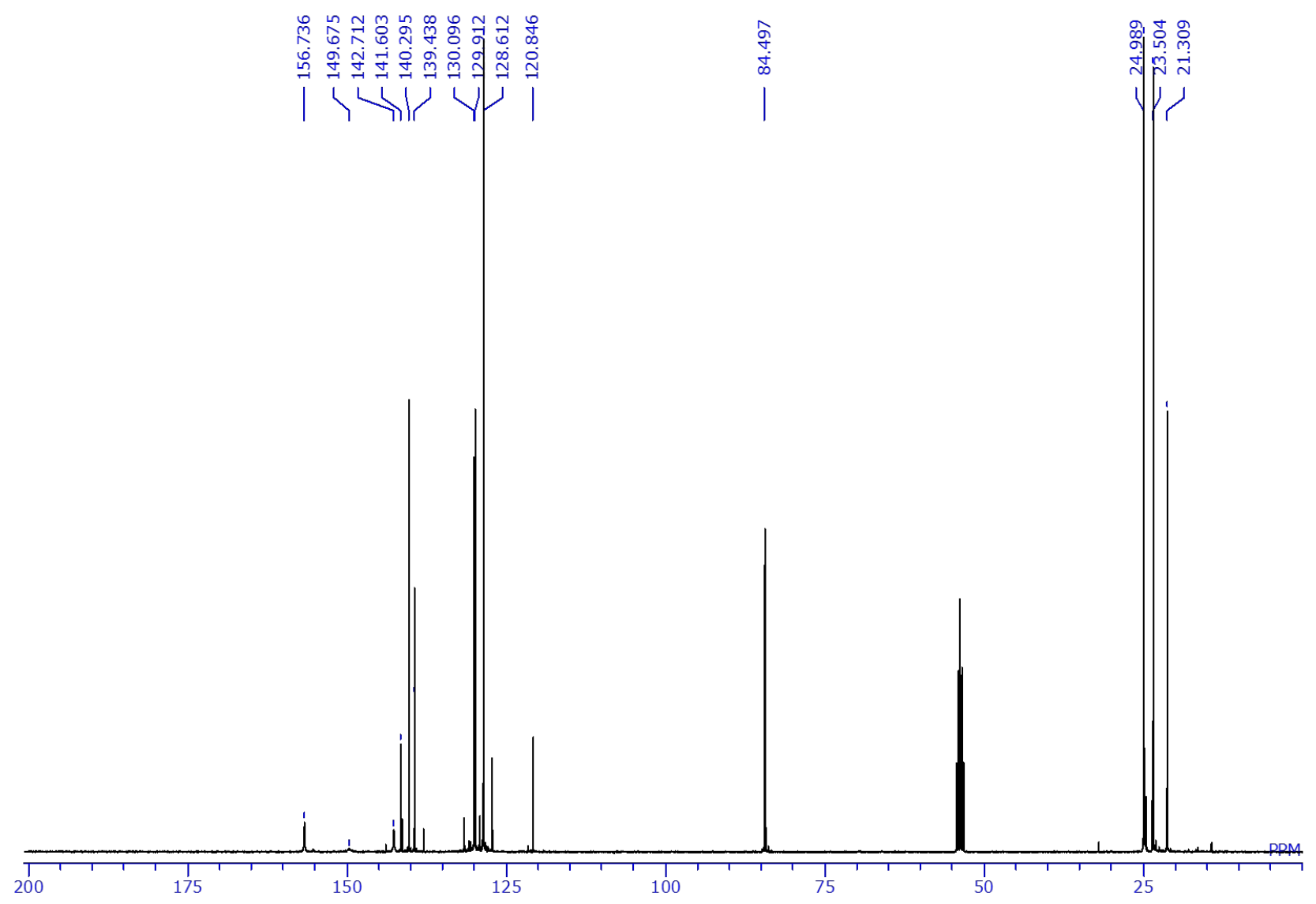

Figure S22. The ${ }^{13} \mathrm{C}$ NMR spectrum $\left(\mathrm{CD}_{2} \mathrm{Cl}_{2}\right)$ of $\mathbf{3 A c}$ 
NMR yield of 3Aa, $3 \mathrm{Ab}$ and $3 \mathrm{Ac}$ in run 2, Table 2

The procedure described in run 9, Table 1 was used. Reaction condition: Toluene (500 $\mu \mathrm{L}), 1$ (75.9 mg, 0.202 mmol), 4-bromophenyl-acetylene (39.0 mg, $0.220 \mathrm{mmol}),{ }^{n} \mathrm{BuLi}(0.100 \mathrm{M}$ diluted in toluene, $60.0 \mu \mathrm{L}, 6.00 \mu \mathrm{mol})$, $\operatorname{DME}(0.100 \mathrm{M}$ diluted in toluene, $60.0 \mu \mathrm{L}, 6.00 \mu \mathrm{mol}), 100{ }^{\circ} \mathrm{C}, 3 \mathrm{~h}$, trimethoxybenzene $(22.0 \mathrm{mg}, 0.131 \mathrm{mmol})$, crude (123 mg); NMR yield: 3Aa, 20\%; 3Ab, 5\%; 3Ac, 69\%. See Figure S23 for NMR spectrum of the crude product.

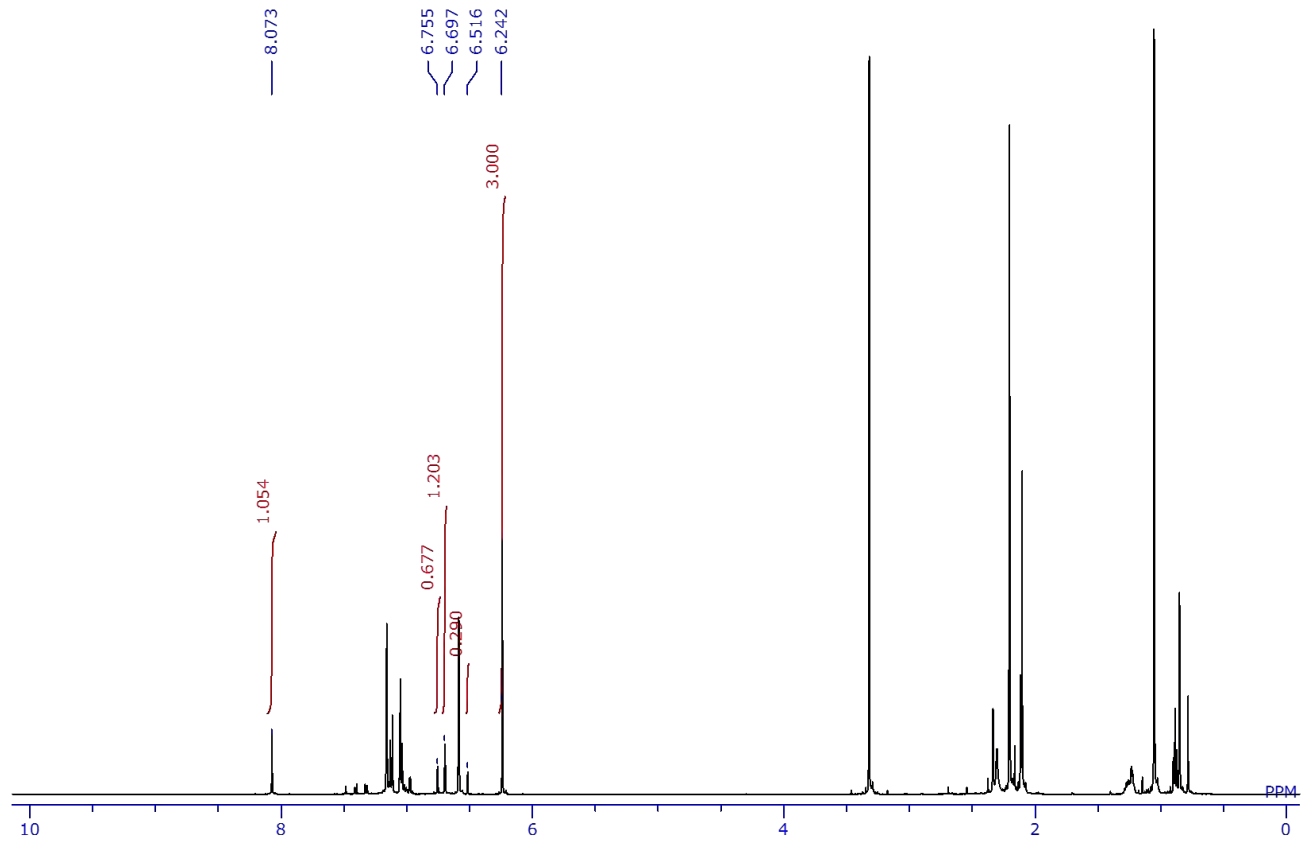

Figure S23. The ${ }^{1} \mathrm{H}$ NMR spectrum of the reaction mixture in run 2, Table 2 (6.70 ppm: 3Aa; 6.76 ppm: 3Ab; 8.07 ppm: 3Ac; 6.24 ppm: internal standard, 1,3,5-trimethoxybenzene) 


\section{Direct reaction of 1 with 3-bromophenylacetylene (Table 2, run 3)}

In a glovebox, to a toluene solution $(1.25 \mathrm{~mL})$ of $\mathbf{1}(188 \mathrm{mg}, 0.500 \mathrm{mmol})$ in a $10 \mathrm{~mL} \mathrm{~J}$-young tube, 3-bromophenyl-acetylene $(99.0 \mathrm{mg}, 0.547 \mathrm{mmol})$ was added. After stirring the reaction mixture at $100{ }^{\circ} \mathrm{C}$ for $14 \mathrm{~h}$, volatiles were removed from the clear solution in vacuo. Purification of the residue by GPC (24 cycles) afforded clear oils of $\mathbf{3 B a}(121 \mathrm{mg}, 0.218 \mathrm{mmol}, 44 \%)$ and $\mathbf{3 B b}(25.0 \mathrm{mg}, 0.045 \mathrm{mmol}$, 9\%). Single crystals of 3Ba suitable for X-ray diffraction analysis were obtained by recrystallization from its hexane solution. 3 Ba: ${ }^{1} \mathrm{H}$ NMR $\left(400 \mathrm{MHz}, \mathrm{CD}_{2} \mathrm{Cl}_{2}\right) \delta 0.93\left(\mathrm{~s}, 12 \mathrm{H}\right.$, pin- $\left.\mathrm{CH}_{3}\right), 2.13$ (br s, 12H,o-CH$), 2.24\left(\mathrm{~s}, 6 \mathrm{H}, p-\mathrm{CH}_{3}\right), 6.33(\mathrm{~s}, 1 \mathrm{H}, \mathrm{CH}), 6.73$ (s, 4H, ArH of Mes), 7.03 (t, $J=8 \mathrm{~Hz}, 1 \mathrm{H}, \mathrm{ArH}), 7.12(\mathrm{dq}, J=8,1 \mathrm{~Hz}, 1 \mathrm{H}, \mathrm{ArH}), 7.28(\mathrm{dq}, J=8,1 \mathrm{~Hz}, 1 \mathrm{H}, \mathrm{ArH})$, $7.41(\mathrm{t}, J=2 \mathrm{~Hz}, 1 \mathrm{H}, \mathrm{ArH}) ;{ }^{11} \mathrm{~B} \mathrm{NMR}\left(128 \mathrm{MHz}, \mathrm{CDCl}_{3}\right) \delta 31$ (br s), 81 (br s); ${ }^{13} \mathrm{C} \mathrm{NMR}\left(101 \mathrm{MHz}^{\mathrm{CDCl}} \mathrm{CD}_{3} \delta\right.$ $21.3\left(\mathrm{CH}_{3}\right), 23.7\left(\mathrm{CH}_{3}\right), 24.4\left(\mathrm{CH}_{3}\right), 24.4\left(\mathrm{CH}_{3}\right), 83.5\left(4^{\circ}\right), 122.4\left(4^{\circ}\right), 126.0(\mathrm{CH}), 128.6(\mathrm{CH}), 129.5(\mathrm{CH}), 129.7$ $(\mathrm{CH}), 130.5(\mathrm{CH}), 133.4$ (br, $\mathrm{CH}$, bonding to the B nucleus), $139.5\left(4^{\circ}\right), 141.6\left(4^{\circ}\right), 143.0\left(\mathrm{br}, 4^{\circ}\right.$, bonding to the B nucleus), $147.2\left(4^{\circ}\right), 169.0$ (br, $4^{\circ}$, bonding to the $\mathrm{B}$ nucleus); mp 107-108 ${ }^{\circ} \mathrm{C}$; HRMS (ESI+) Calcd for $\mathrm{C}_{32} \mathrm{H}_{39} \mathrm{~B}_{2}{ }^{79} \mathrm{BrO}_{2}$ and $\mathrm{C}_{32} \mathrm{H}_{39} \mathrm{~B}_{2}{ }^{81} \mathrm{BrO}_{2}\left[\mathrm{M}^{+}\right]$: 556.2320, 558.2299, found: 556.2311, 558.2302; 3Bb: ${ }^{1} \mathrm{H}$ NMR (400 $\left.\mathrm{MHz}, \mathrm{C}_{6} \mathrm{D}_{6}\right) \delta 0.78\left(\mathrm{~s}, 12 \mathrm{H}\right.$, pin- $\left.\mathrm{CH}_{3}\right), 2.16\left(\mathrm{~s}, 6 \mathrm{H}, p-\mathrm{CH}_{3}\right), 2.31\left(\mathrm{~s}, 12 \mathrm{H}, o-\mathrm{CH}_{3}\right), 6.74(\mathrm{~s}, 4 \mathrm{H}, \mathrm{ArH}$ of Mes), $6.84(\mathrm{t}$, $J=8 \mathrm{~Hz}, 1 \mathrm{H}, \mathrm{ArH}), 7.23(\mathrm{~d}, J=8 \mathrm{~Hz}, 1 \mathrm{H}, \mathrm{ArH}), 7.49(\mathrm{~d}, J=8,1 \mathrm{~Hz}, 1 \mathrm{H}, \operatorname{ArH}), 7.50(\mathrm{~s}, 1 \mathrm{H}, \mathrm{CH}), 8.05(\mathrm{t}, J=2$ $\mathrm{Hz}, 1 \mathrm{H}, \mathrm{ArH}$ ); HRMS (ESI+) Calcd for $\mathrm{C}_{32} \mathrm{H}_{39} \mathrm{~B}_{2}{ }^{79} \mathrm{BrO}_{2}$ and $\mathrm{C}_{32} \mathrm{H}_{39} \mathrm{~B}_{2}{ }^{81} \mathrm{BrO}_{2}\left[\mathrm{M}^{+}\right]$: 556.2313, 558.2288, found: $556.2317,558.2316$.

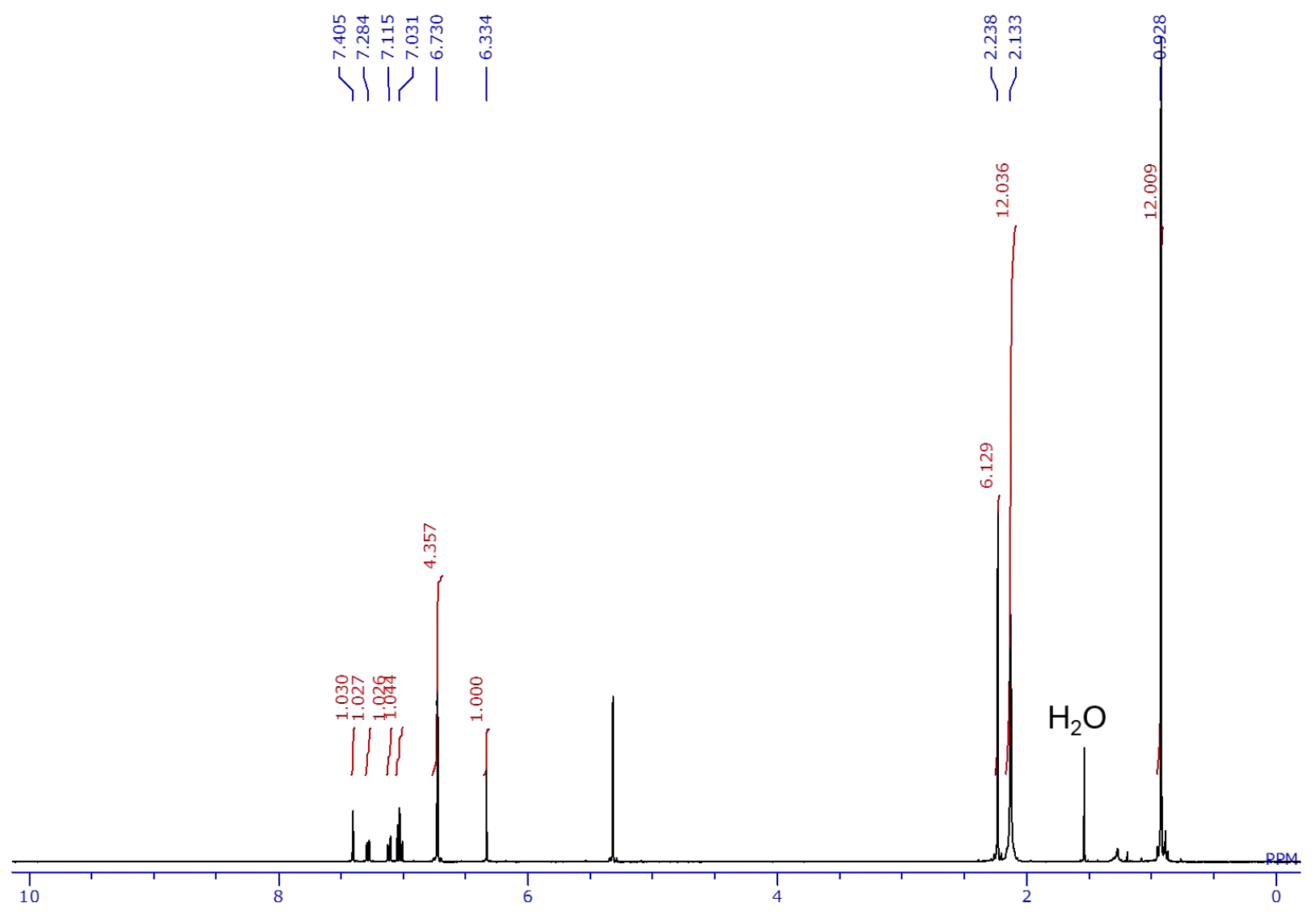

Figure S24. The ${ }^{1} \mathrm{H}$ NMR spectrum $\left(\mathrm{CD}_{2} \mathrm{Cl}_{2}\right)$ of $\mathbf{3 B a}$ 


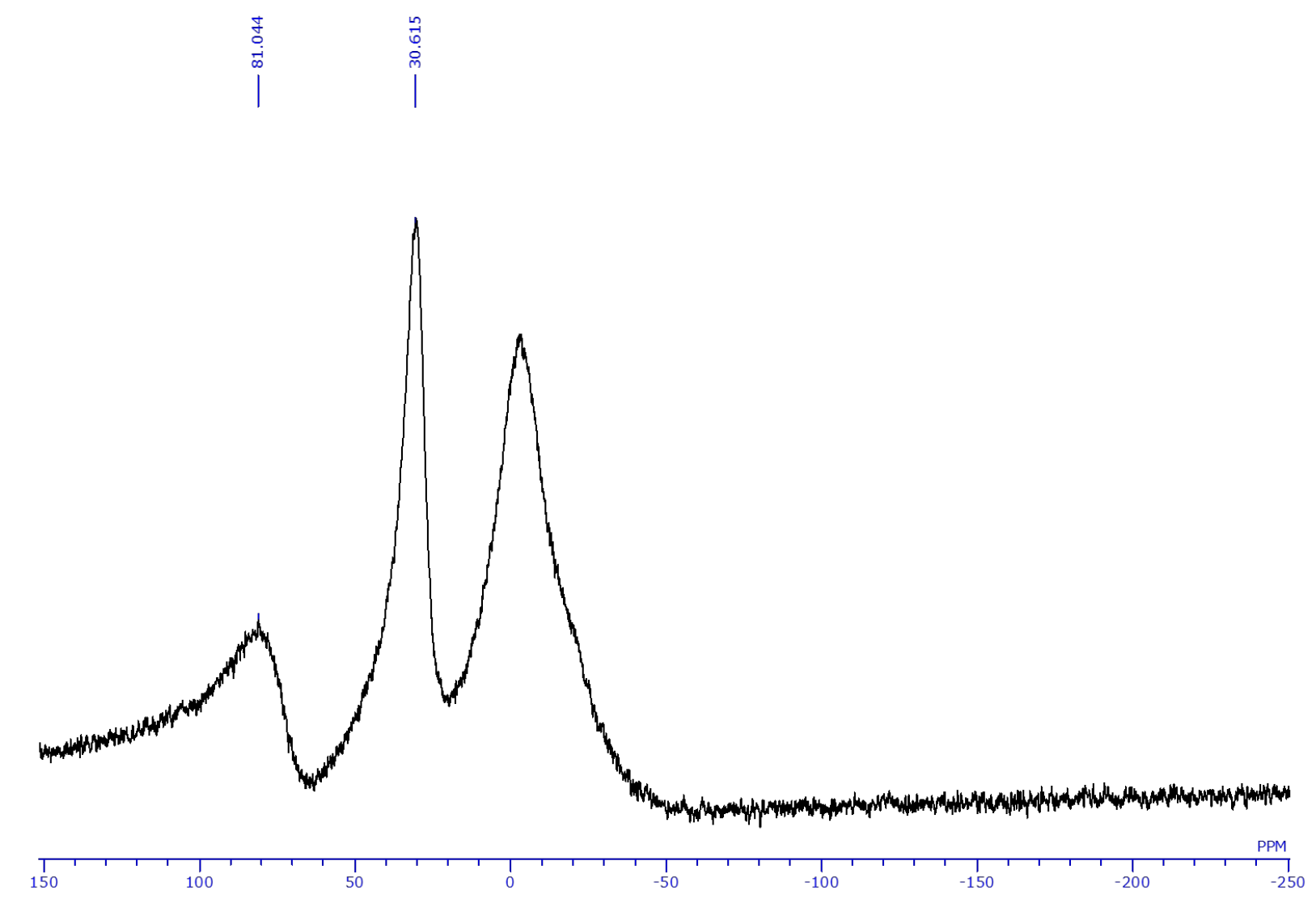

Figure S25. The ${ }^{11} \mathrm{~B}$ NMR spectrum (borosilicate NMR tube, $\mathrm{CDCl}_{3}$ ) of $\mathbf{3 B a}$

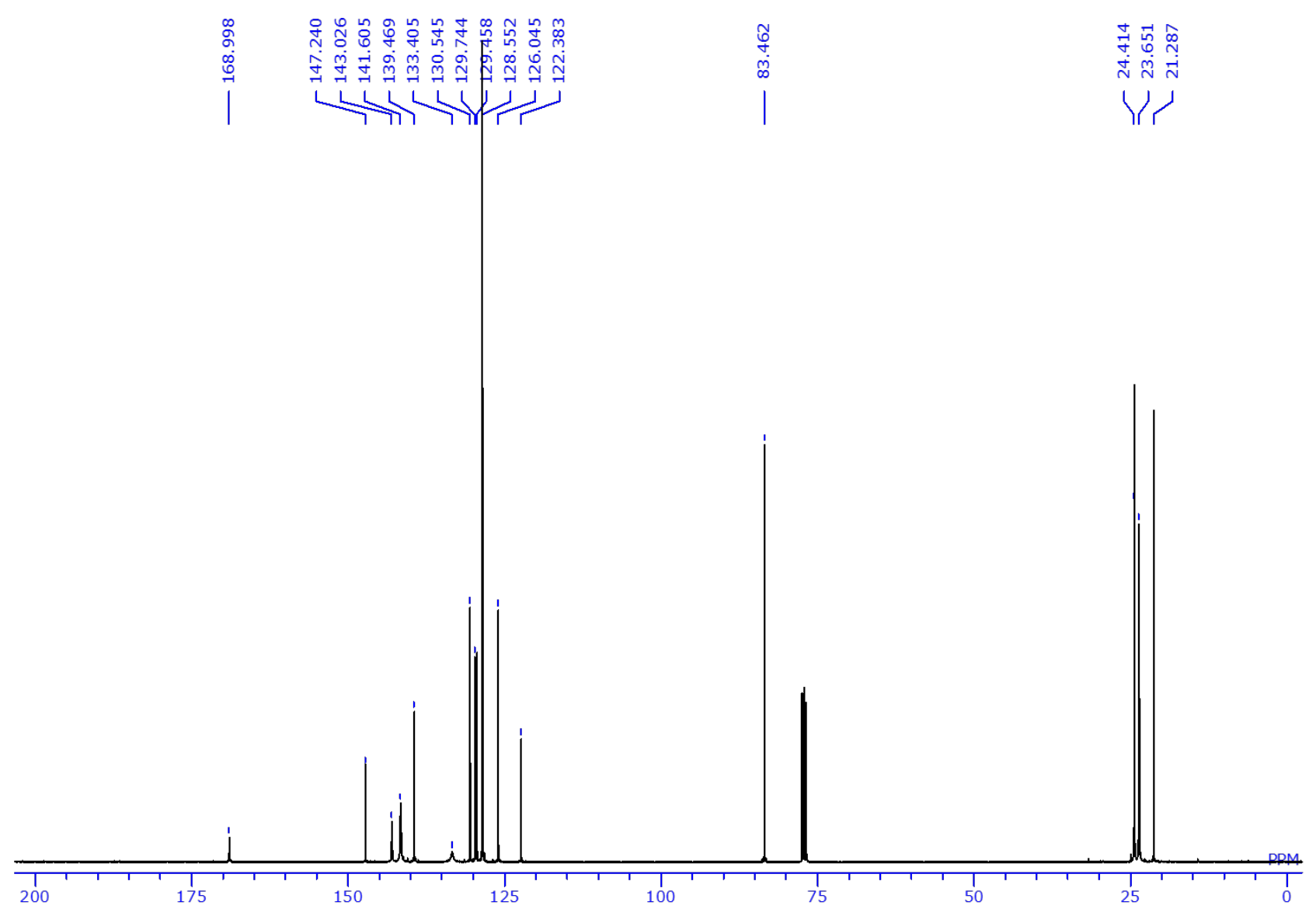

Figure S26. The ${ }^{13} \mathrm{C}$ NMR spectrum $\left(\mathrm{CDCl}_{3}\right)$ of $\mathbf{3 B a}$ 


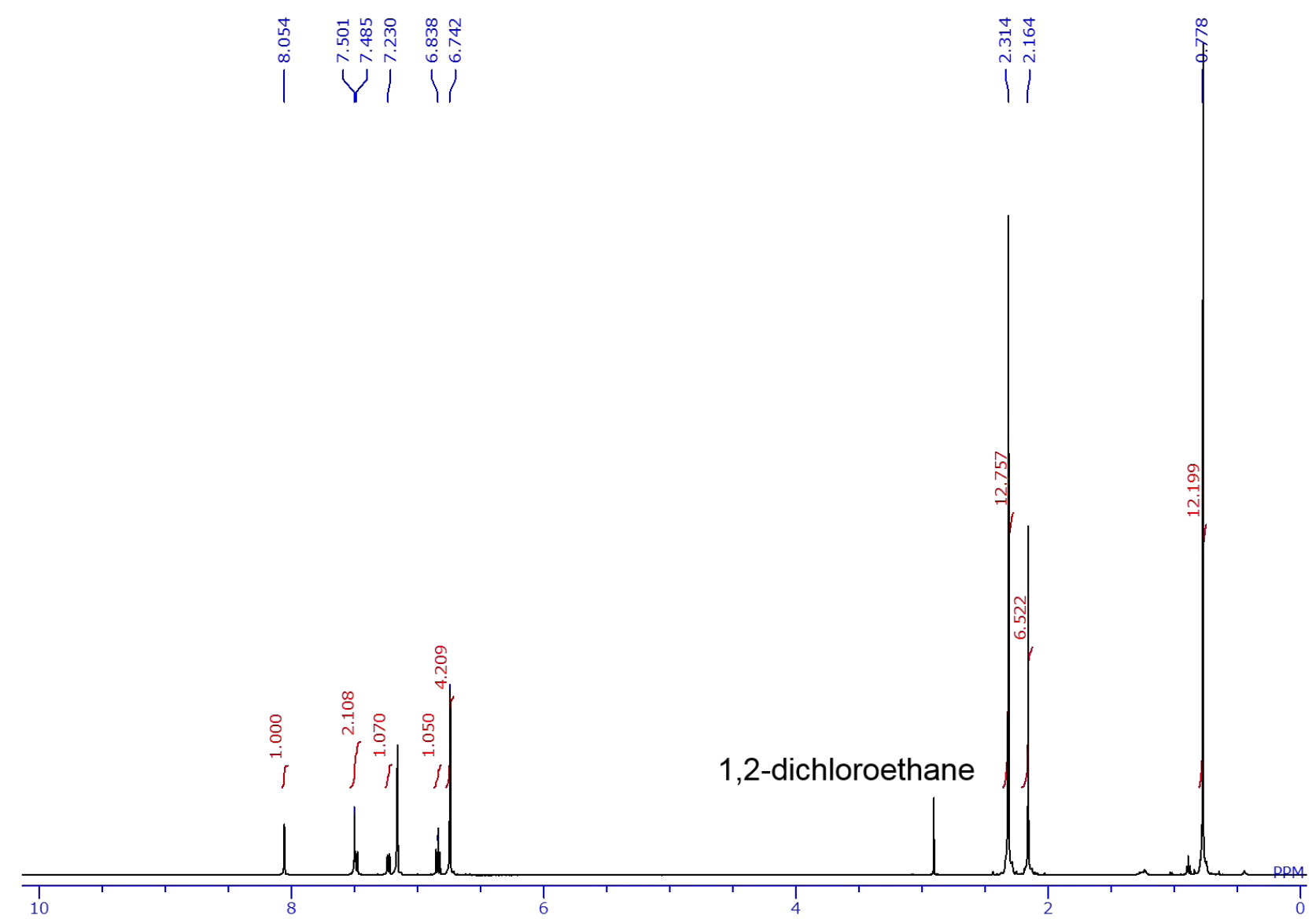

Figure S27. The ${ }^{1} \mathrm{H}$ NMR spectrum $\left(\mathrm{C}_{6} \mathrm{D}_{6}\right)$ of $\mathbf{3 B a}$
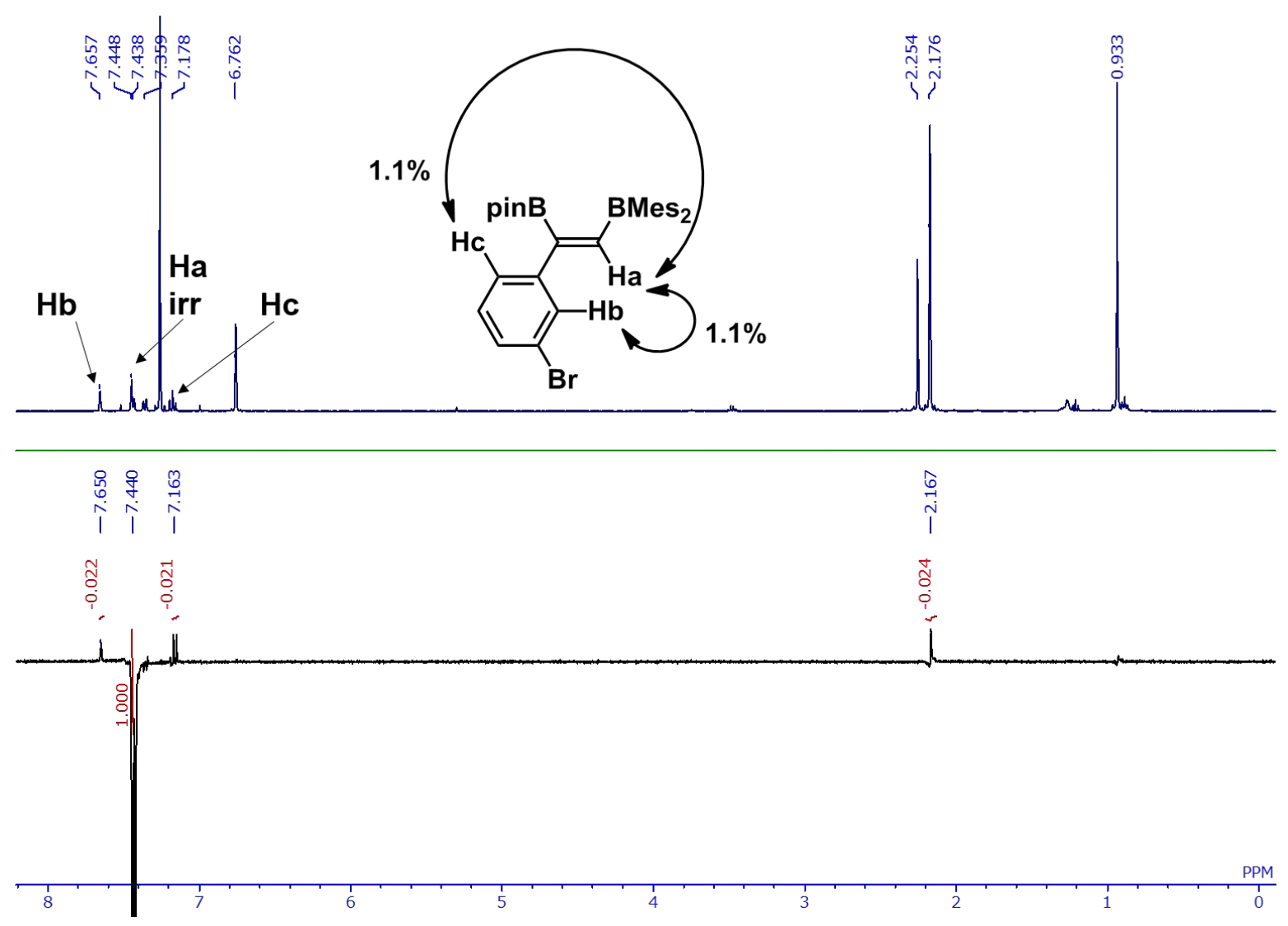

Figure S28. The differential ${ }^{1} \mathrm{H}$ NOE spectrum $\left(\mathrm{C}_{6} \mathrm{D}_{6}\right)$ of $\mathbf{3 B a}$ with irradiation to the signal of vinylic $\mathrm{H}_{\mathrm{a}}$ 


\section{NMR yield of $3 B \mathrm{Ba}$ and $3 \mathrm{Bb}$ in run 3 , Table 2}

The procedure described in run 1, Table 1 was used. Reaction condition: Toluene $(500 \mu L), 1$ (75.3 mg, 0.200 mmol), 3-bromophenyl-acetylene $(42.1 \mathrm{mg}, 0.233 \mathrm{mmol}), 100{ }^{\circ} \mathrm{C}, 14 \mathrm{~h}$, trimethoxybenzene $(16.6 \mathrm{mg}, 0.0988$ mmol), crude (118 mg); NMR yield: 3Ba, 64\%; 3Bb, 20\%. See Figure S29 for NMR spectrum of the crude product.

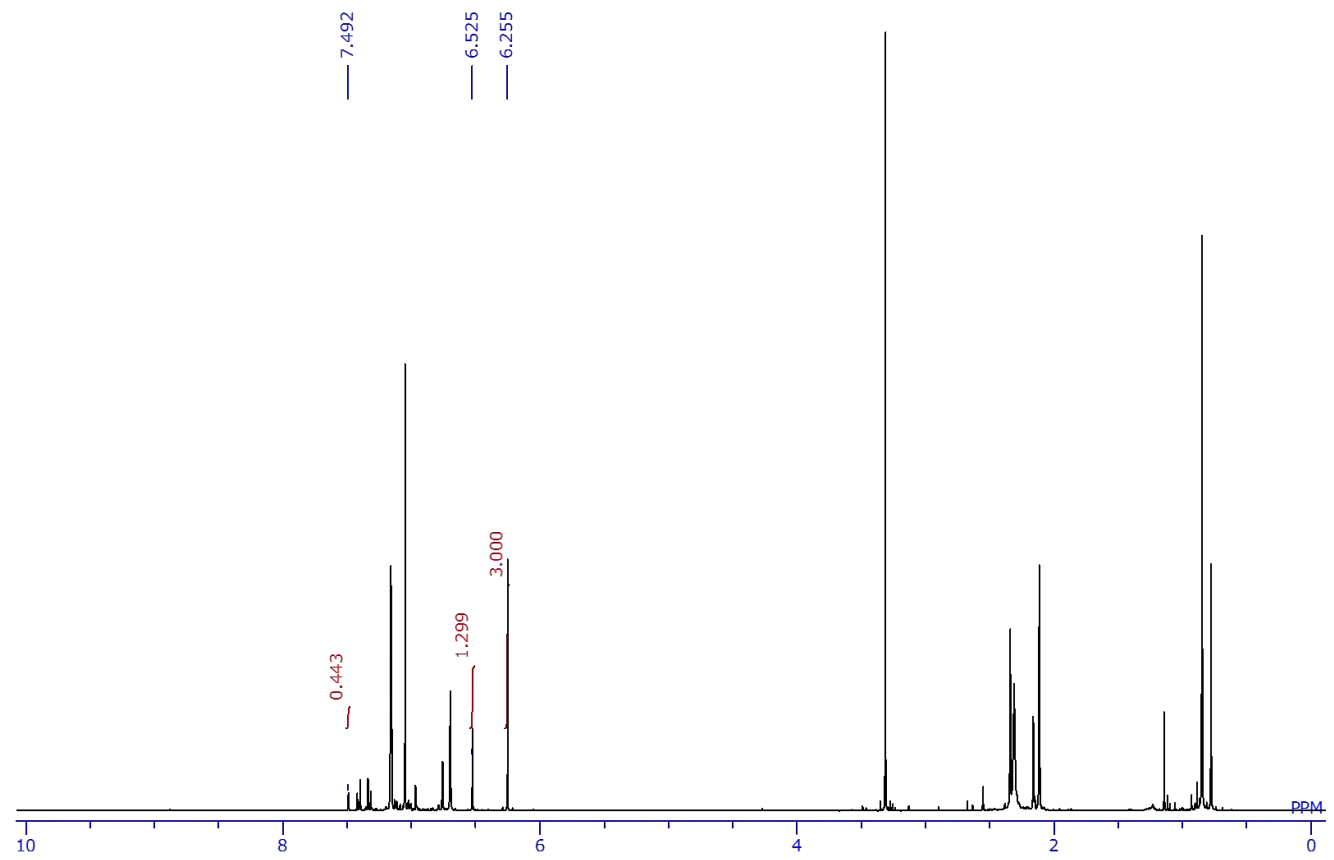

Figure S29. The ${ }^{1} \mathrm{H}$ NMR spectrum of the reaction mixture in run 3, Table 2 (6.53 ppm: 3Ba; 7.49 ppm: 3Bb; 6.25 ppm: internal standard, 1,3,5-trimethoxybenzene) 


\section{Base-catalyzed reaction of 1 with 3-bromophenylacetylene (Table 2, run 4)}

In a glovebox, to a solution of 3-bromophenyl-acetylene $(100 \mathrm{mg}, 0.552 \mathrm{mmol})$ in toluene $(1.25 \mathrm{~mL}),{ }^{n} \mathrm{BuLi}$ $(0.100 \mathrm{M}$ diluted in toluene, $150 \mu \mathrm{L}, 15.0 \mu \mathrm{mol})$ was added dropwise at room temperature. After stirring the reaction mixture at room temperature for $3 \mathrm{~min}, 1(188.2 \mathrm{mg}, 0.500 \mathrm{mmol})$ and DME $(0.100 \mathrm{M}$ diluted in toluene, $150 \mu \mathrm{L}, 15.0 \mu \mathrm{mol})$ were added to the reaction mixture at room temperature. After the reaction mixture stirred at $100{ }^{\circ} \mathrm{C}$ for $3 \mathrm{~h}$, volatiles were removed from the pale yellow solution in vacuo. The residue was triturated with hexane and the resulting suspension was filtered through a pad of Celite. After volatiles were removed from the filtrate in vacuo, the residue were purified by recycling GPC (7 cycles) afforded yellow oil of 3Bc (169 mg, 0.304 mmol, 61\%). Single crystals of $\mathbf{3 B c}$ suitable for X-ray diffraction analysis were obtained by slow evaporation of its hexane solution to the coexistent silica-gel in a capped vial at room temperature. $3 \mathbf{B c}$ : ${ }^{1} \mathrm{H}$ NMR (400 MHz, $\left.\mathrm{C}_{6} \mathrm{D}_{6}\right) \delta 1.04\left(\mathrm{~s}, 12 \mathrm{H}\right.$, pin- $\left.\mathrm{CH}_{3}\right), 2.08\left(\mathrm{~s}, 6 \mathrm{H}, p-\mathrm{CH}_{3}\right), 2.26\left(\mathrm{~s}, 12 \mathrm{H}, o-\mathrm{CH}_{3}\right), 6.62(\mathrm{t}, 5 \mathrm{H}, \mathrm{ArH}$ of $\mathrm{Mes}(4 \mathrm{H})$ and $\operatorname{ArH}(1 \mathrm{H})), 6.97$ (dq, $J=8,1 \mathrm{~Hz}, 1 \mathrm{H}, \mathrm{ArH}), 7.26$ (dq, $J=8,1 \mathrm{~Hz}, 1 \mathrm{H}, \mathrm{ArH}), 7.52$ (brs, 1H, ArH), 8.12 (s, 1H, CH);

${ }^{11} \mathrm{~B}$ NMR (128 MHz, $\left.\mathrm{CD}_{2} \mathrm{Cl}_{2}\right) \delta 30$ (br s), 77 (br s); $\left.{ }^{13} \mathrm{C} \mathrm{NMR} \mathrm{(101} \mathrm{MHz,} \mathrm{CD}_{2} \mathrm{Cl}_{2}\right) \delta 21.4\left(\mathrm{CH}_{3}\right), 23.7\left(\mathrm{CH}_{3}\right), 25.0$ $\left(\mathrm{CH}_{3}\right), 24.4\left(\mathrm{CH}_{3}\right), 84.5\left(4^{\circ}\right), 121.5\left(4^{\circ}\right), 126.9(\mathrm{CH}), 127.3(\mathrm{CH}), 128.7(\mathrm{CH}), 129.3(\mathrm{CH}), 131.1(\mathrm{CH}), 139.3\left(4^{\circ}\right)$, $140.3\left(4^{\circ}\right), 142.7\left(\mathrm{br}, 4^{\circ}\right.$, bonding to the B nucleus), $145.0\left(4^{\circ}\right), 149.2\left(\mathrm{br}, 4^{\circ}\right.$, bonding to the B nucleus), 157.5(br, $\mathrm{CH}$, bonding to the $\mathrm{B}$ nucleus); mp $135-137{ }^{\circ} \mathrm{C}$ (decomp.); HRMS (ESI+) Calcd for $\mathrm{C}_{32} \mathrm{H}_{39} \mathrm{~B}_{2}{ }^{79} \mathrm{BrO}_{2}$ and $\mathrm{C}_{32} \mathrm{H}_{39} \mathrm{~B}_{2}{ }^{81} \mathrm{BrO}_{2}\left[\mathrm{M}^{+}\right]$: 556.2320, 558.2299, found: 556.2299, 558.2303.

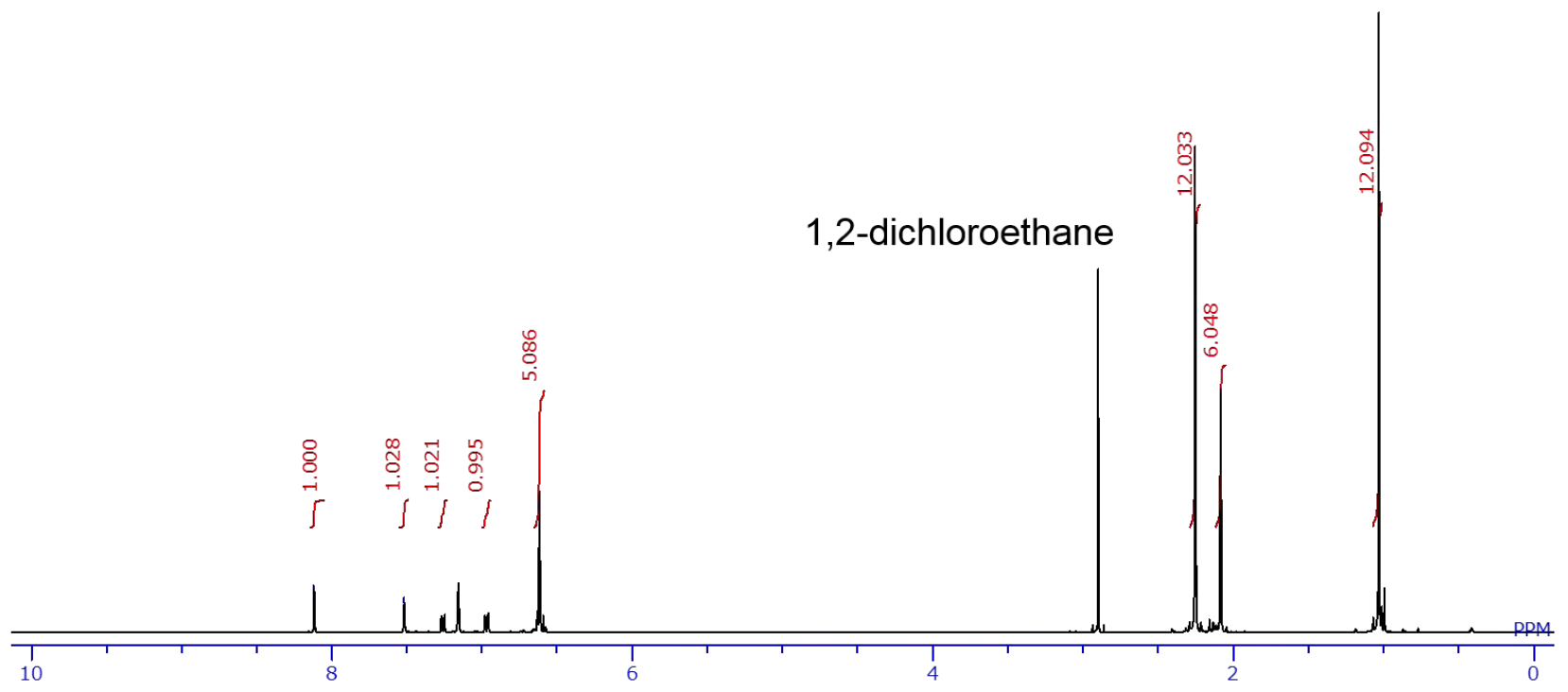

Figure S30. The ${ }^{1} \mathrm{H}$ NMR spectrum $\left(\mathrm{C}_{6} \mathrm{D}_{6}\right)$ of $\mathbf{3 B c}$ 


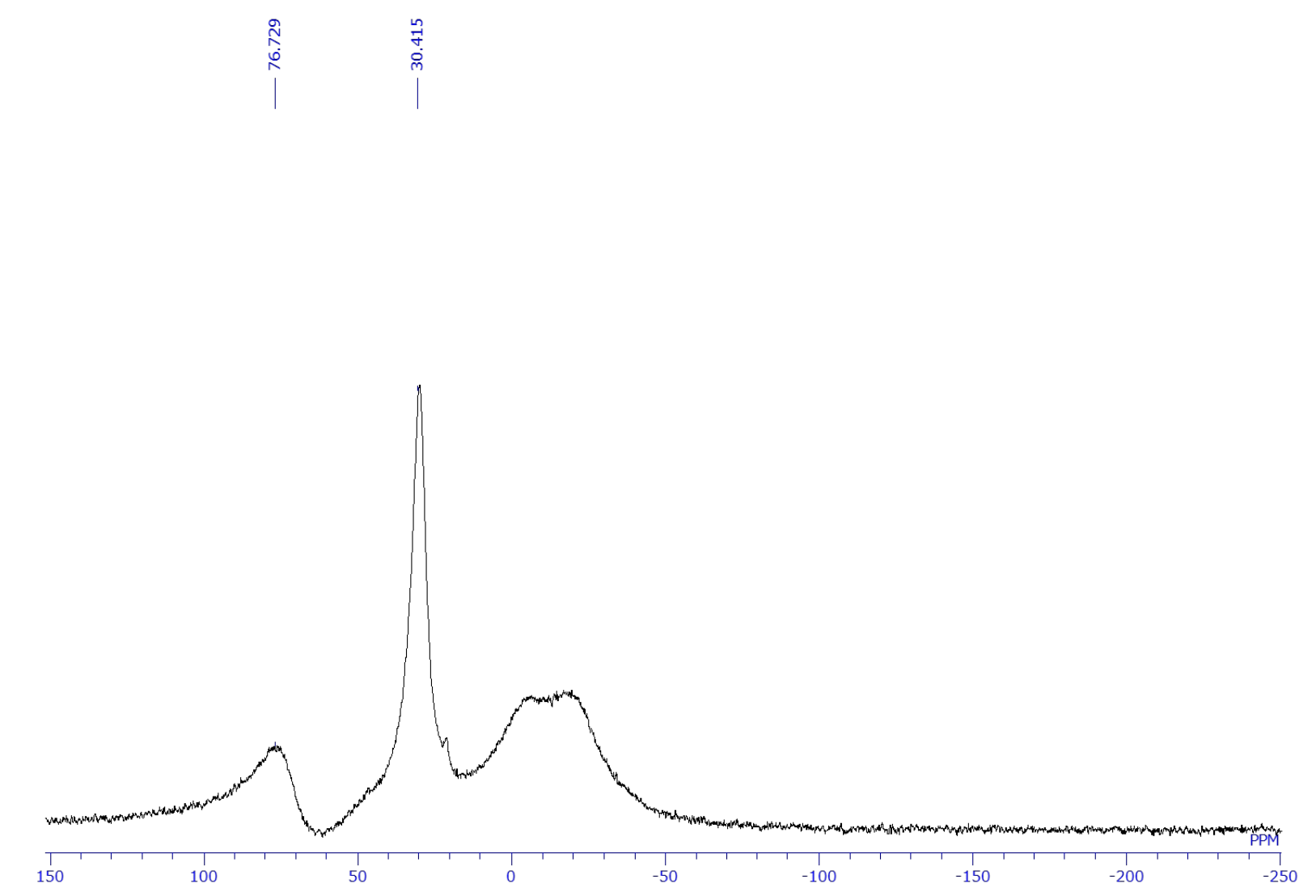

Figure S31. The ${ }^{11} \mathrm{~B}$ NMR spectrum (borosilicate NMR tube, $\mathrm{CD}_{2} \mathrm{Cl}_{2}$ ) of $\mathbf{3 B c}$
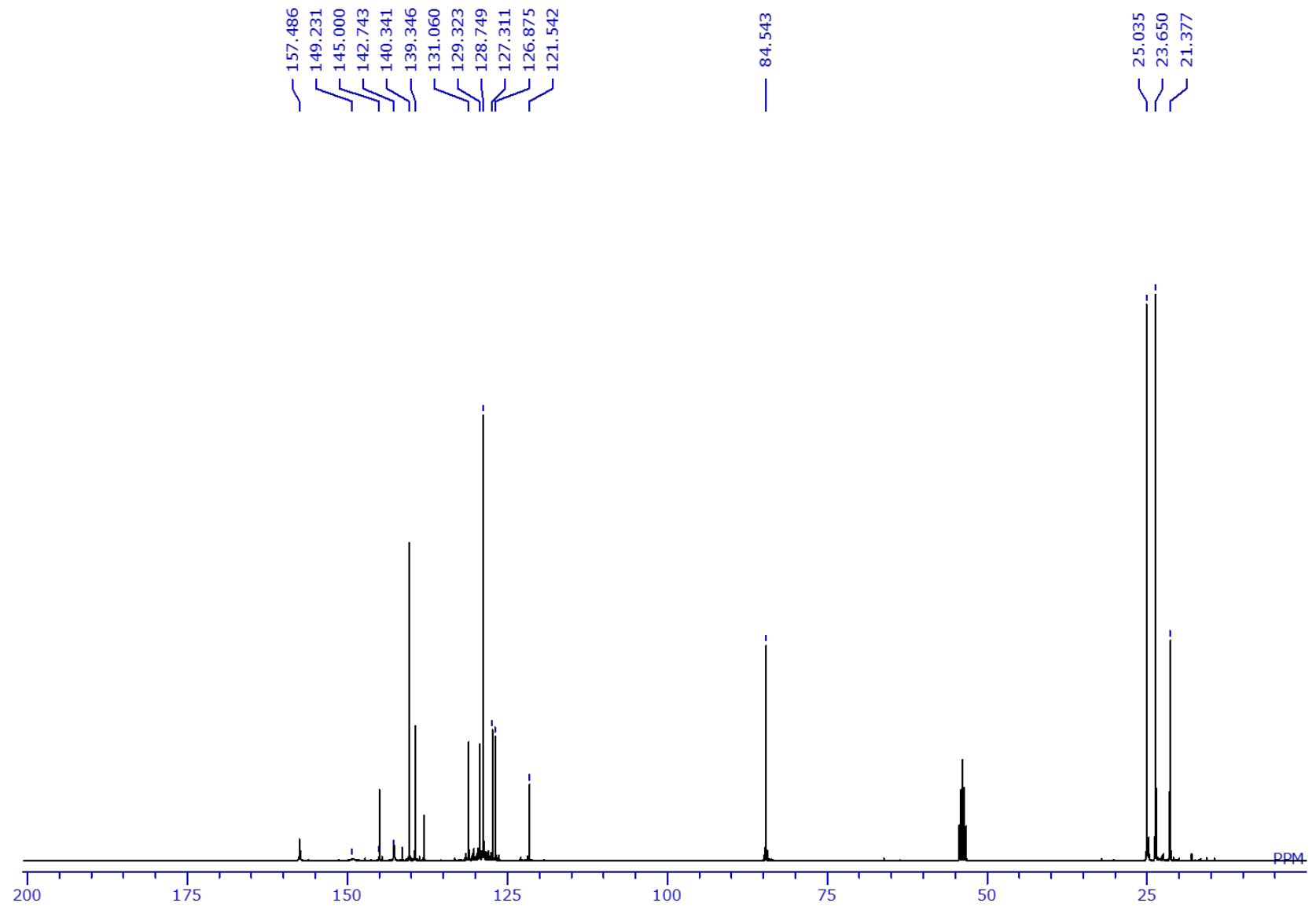

Figure S32. The ${ }^{13} \mathrm{C}$ NMR spectrum $\left(\mathrm{CD}_{2} \mathrm{Cl}_{2}\right)$ of $\mathbf{3 B c}$ 
NMR yield of $3 B a, 3 B b$ and $3 B c$, in run 4 , Table 2

The procedure described in run 9, Table 1 was used. Reaction condition: Toluene (500 $\mu \mathrm{L}), 1$ (75.0 mg, 0.200 mmol), 3-bromophenyl-acetylene $(40.8 \mathrm{mg}, 0.226 \mathrm{mmol}),{ }^{n} \mathrm{BuLi}(0.100 \mathrm{M}$ diluted in toluene, $60.0 \mu \mathrm{L}, 6.00 \mu \mathrm{mol})$, $\operatorname{DME}(0.100 \mathrm{M}$ diluted in toluene, $60.0 \mu \mathrm{L}, 6.00 \mu \mathrm{mol}), 100{ }^{\circ} \mathrm{C}, 3 \mathrm{~h}$, trimethoxybenzene $(16.1 \mathrm{mg}, 0.0958 \mathrm{mmol})$, crude (121.7 mg); NMR yield: 3Ba, 10\%; 3Bb, 5\%; 3Bc, 68\%. See Figure S33 for NMR spectrum of the crude product.

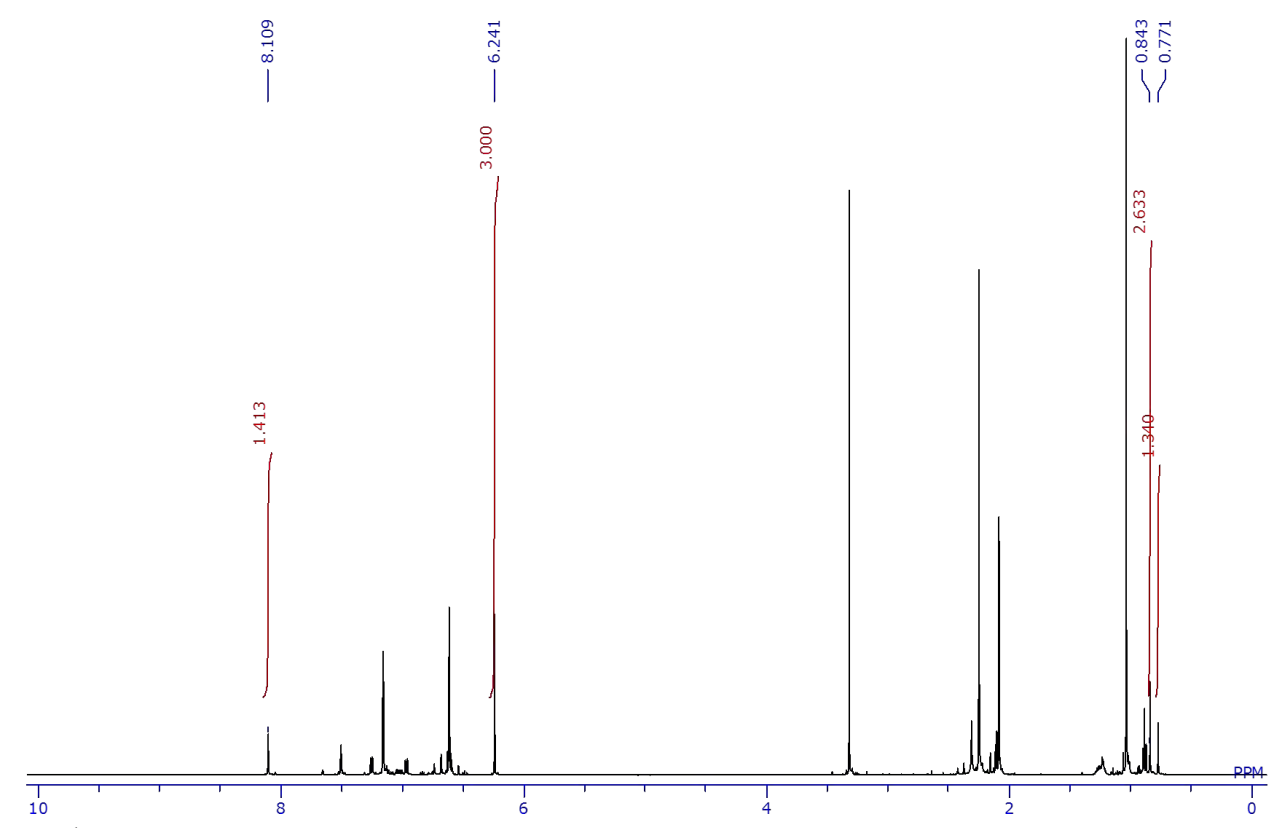

Figure S33. The ${ }^{1} \mathrm{H}$ NMR spectrum of the reaction mixture in run 4, Table 2 (0.843 ppm: 3Ba; 0.771 ppm: 3Bb; 8.11 ppm: 3Bc; 6.24 ppm: internal standard, 1,3,5-trimethoxybenzene) 


\section{Direct reaction of 1 with 4-dimethylaminophenylacetylene (Table 2, run 5)}

In a glovebox, to a toluene solution $(1.25 \mathrm{~mL})$ of $1(188 \mathrm{mg}, 0.500 \mathrm{mmol})$ in a $10 \mathrm{~mL}$ J-young tube, 4-dimethylamino-phenylacetylene $(79.8 \mathrm{mg}, 0.550 \mathrm{mmol})$ was added. After stirring the reaction mixture at $100{ }^{\circ} \mathrm{C}$ for $6 \mathrm{~h}$, volatiles were removed from the reaction mixture in vacuo. Purification of the residue by recycling GPC (25 cycles) afforded yellow oils of 3Ca (49.2 mg, $0.094 \mathrm{mmol}, 19 \%)$ and 3Cb (131 mg, $0.250 \mathrm{mmol}, 50 \%)$. Single crystals of $\mathbf{3 C b}$ suitable for X-ray diffraction analysis were obtained by recrystallization from its hexane/benzene (5:1, v/v) solution. 3Ca: ${ }^{1} \mathrm{H}$ NMR $\left(400 \mathrm{MHz}, \mathrm{C}_{6} \mathrm{D}_{6}\right) \delta 0.89\left(\mathrm{~s}, 12 \mathrm{H}\right.$, pin- $\left.\mathrm{CH}_{3}\right), 2.14\left(\mathrm{~s}, 6 \mathrm{H}, \mathrm{CH}_{3}\right.$ of $\mathrm{NMe}_{2}$ ), 2.35 (s, 6H, $p-\mathrm{CH}_{3}$ ), 2.46 (brs, 12H, $p-\mathrm{CH}_{3}$ ), 6.40 (d, $\left.J=9 \mathrm{~Hz}, 2 \mathrm{H}, \mathrm{ArH}\right), 6.75$ (s, 4H, ArH of Mes), 6.76 (s, $1 \mathrm{H}, \mathrm{CH}$ ), $7.48(\mathrm{~d}, J=9 \mathrm{~Hz}, 2 \mathrm{H}, \mathrm{ArH})$; mp 154-156 ${ }^{\circ} \mathrm{C}$; HRMS (ESI+) Calcd for $\mathrm{C}_{34} \mathrm{H}_{45} \mathrm{~B}_{2} \mathrm{NO}_{2}: 521.3636$, found: 521.3641. 3Cb: ${ }^{1} \mathrm{H}$ NMR (400 MHz, $\left.\mathrm{C}_{6} \mathrm{D}_{6}\right) \delta 0.88\left(\mathrm{~s}, 12 \mathrm{H}\right.$, pin- $\left.\mathrm{CH}_{3}\right), 2.18\left(\mathrm{~s}, 6 \mathrm{H}, \mathrm{CH}_{3}\right.$ of $\left.\mathrm{NMe}_{2}\right), 2.43$ (s, $\left.12 \mathrm{H}, o-\mathrm{CH}_{3}\right), 2.49$ (s, 6H, o- $\left.\mathrm{CH}_{3}\right), 6.61(\mathrm{~d}, J=9 \mathrm{~Hz}, 2 \mathrm{H}, \mathrm{ArH}), 6.78$ (s, 4H, ArH of Mes), $7.74(\mathrm{~s}, 1 \mathrm{H}, \mathrm{CH}), 7.83$ $(\mathrm{d}, J=9 \mathrm{~Hz}, 2 \mathrm{H}, \mathrm{ArH}) ;{ }^{11} \mathrm{~B}$ NMR $\left(128 \mathrm{MHz}, \mathrm{C}_{6} \mathrm{D}_{6}\right) \delta 29$ (br s), 71 (br s); ${ }^{13} \mathrm{C}$ NMR $\left(101 \mathrm{MHz}, \mathrm{CDCl}_{3}\right) \delta 21.3$ $\left(\mathrm{CH}_{3}\right), 23.6\left(\mathrm{CH}_{3}\right), 24.8\left(\mathrm{CH}_{3}\right), 40.5\left(\mathrm{CH}_{3}\right), 83.5\left(4^{\circ}\right), 112.4(\mathrm{CH}), 128.2(\mathrm{CH}), 128.3(\mathrm{CH}), 132.0\left(4^{\circ}\right), 138.5\left(4^{\circ}\right)$, $141.2\left(4^{\circ}\right), 143.3\left(\mathrm{br}, 4^{\circ}\right.$, bonding to the B nucleus), 147.8 (br, $\mathrm{CH}$, bonding to the $\mathrm{B}$ nucleus), $150.4\left(4^{\circ}\right), 150.7$ (br, $4^{\circ}$, bonding to the $\mathrm{B}$ nucleus); HRMS (ESI+) Calcd for $\mathrm{C}_{34} \mathrm{H}_{45} \mathrm{~B}_{2} \mathrm{NO}_{2}: 521.3636$, found: 521.3644.

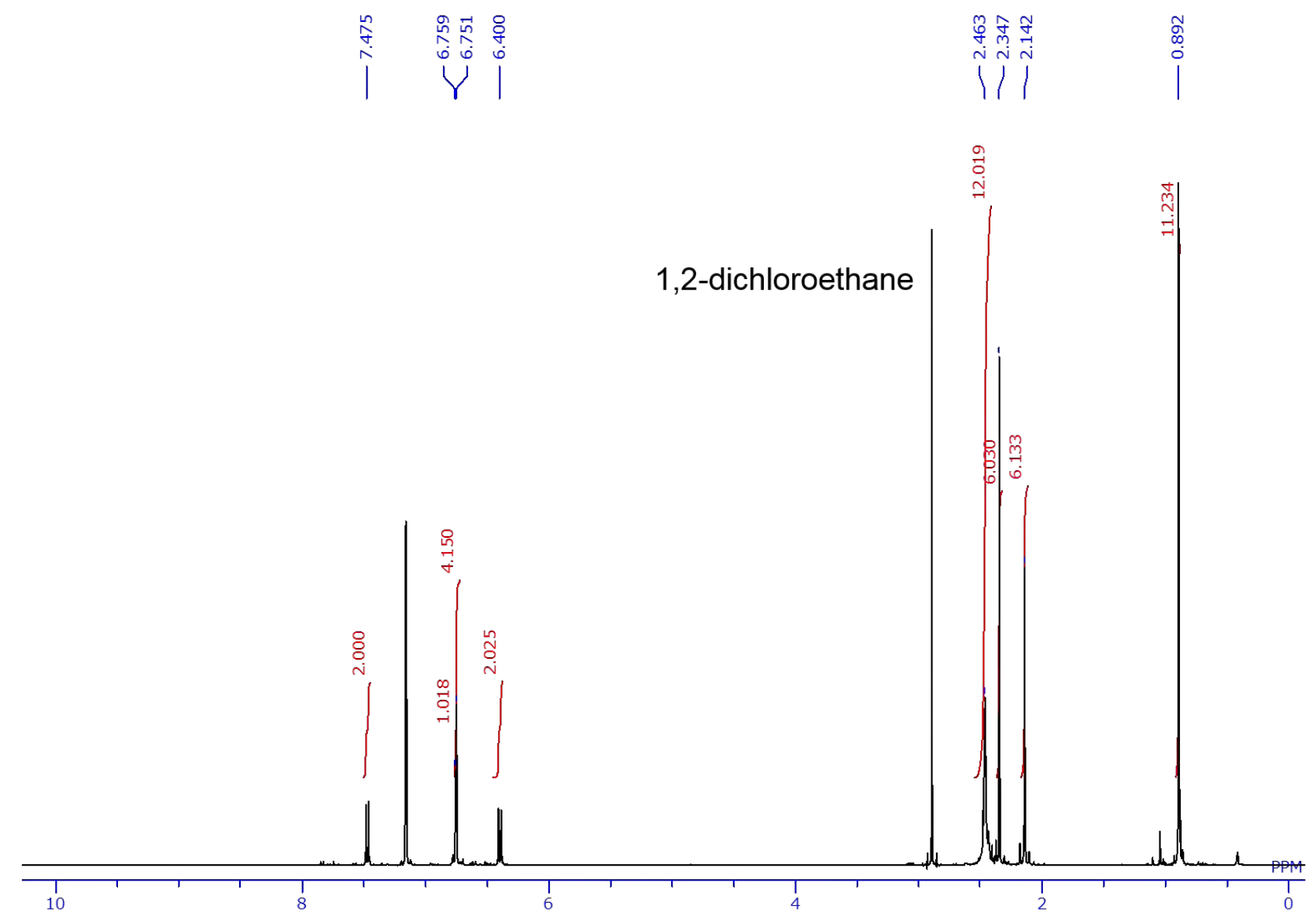

Figure S34. The ${ }^{1} \mathrm{H}$ NMR spectrum $\left(\mathrm{C}_{6} \mathrm{D}_{6}\right)$ of $\mathbf{3 C a}$ 


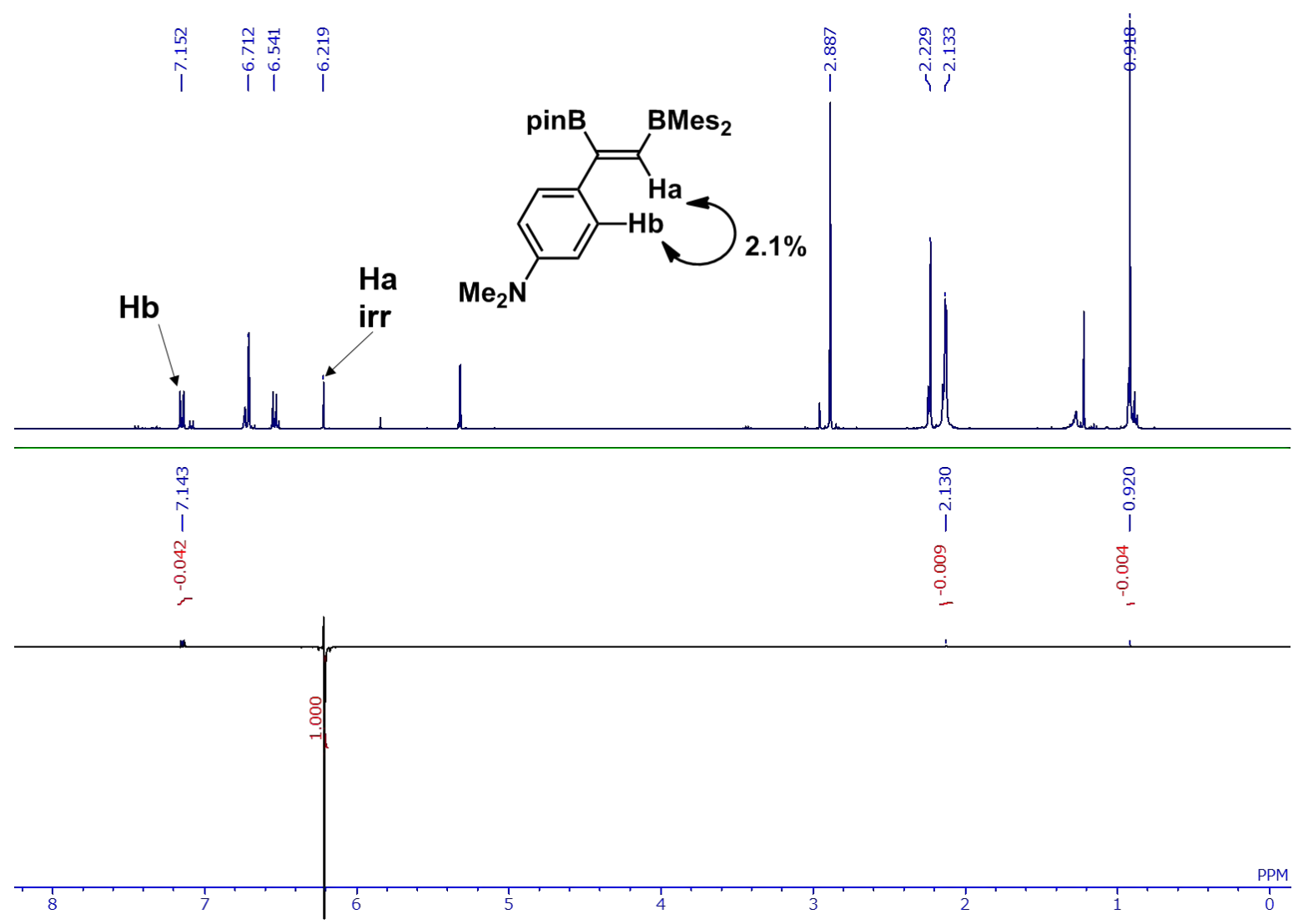

Figure S35. The differential ${ }^{1} \mathrm{H}$ NOE spectrum $\left(\mathrm{CDCl}_{3}\right)$ of $\mathbf{3 C a}$ with irradiation to the signal of vinylic $\mathrm{H}_{\mathrm{a}}$

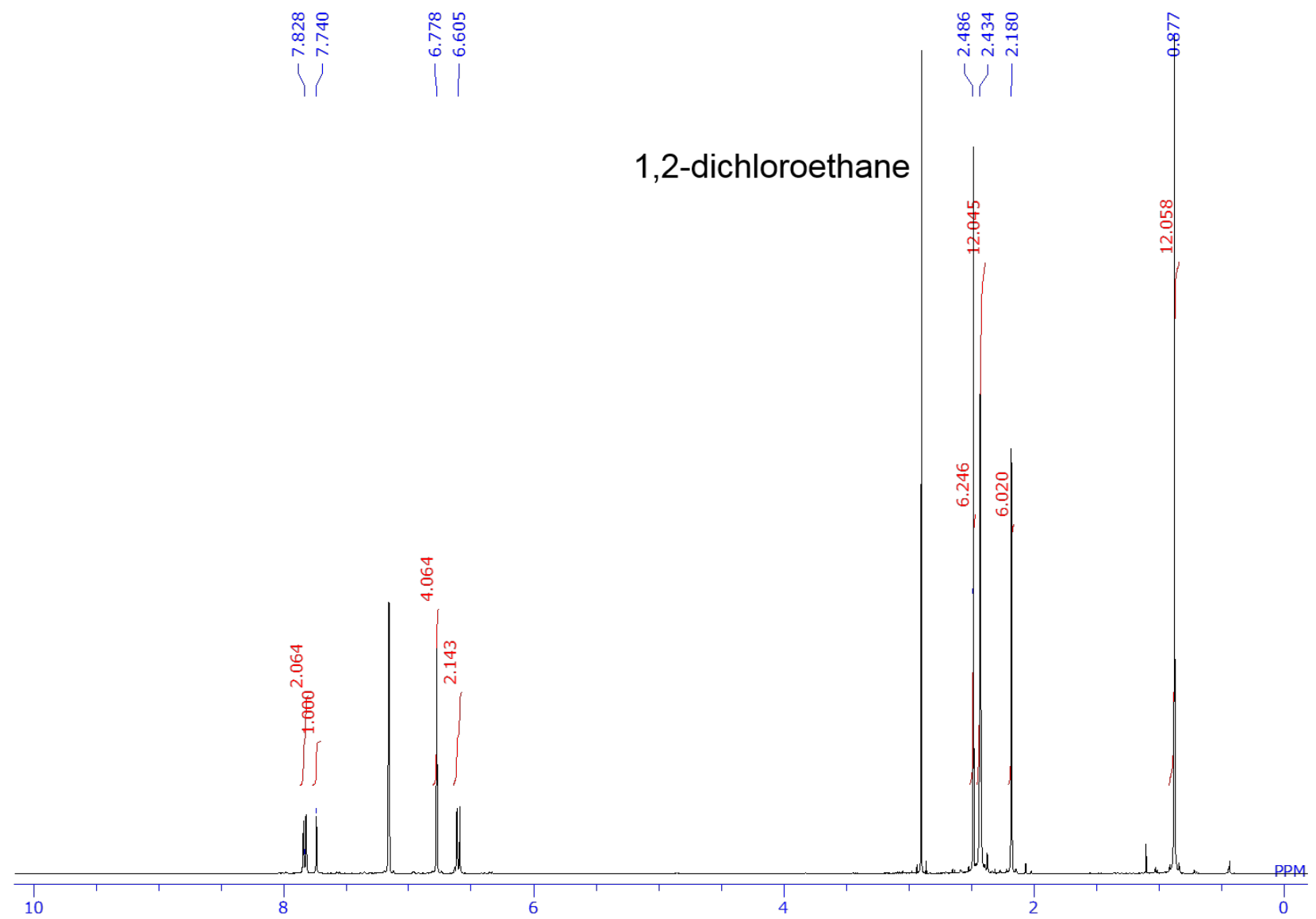

Figure S36. The ${ }^{1} \mathrm{H}$ NMR spectrum $\left(\mathrm{C}_{6} \mathrm{D}_{6}\right)$ of $\mathbf{3 C b}$ 


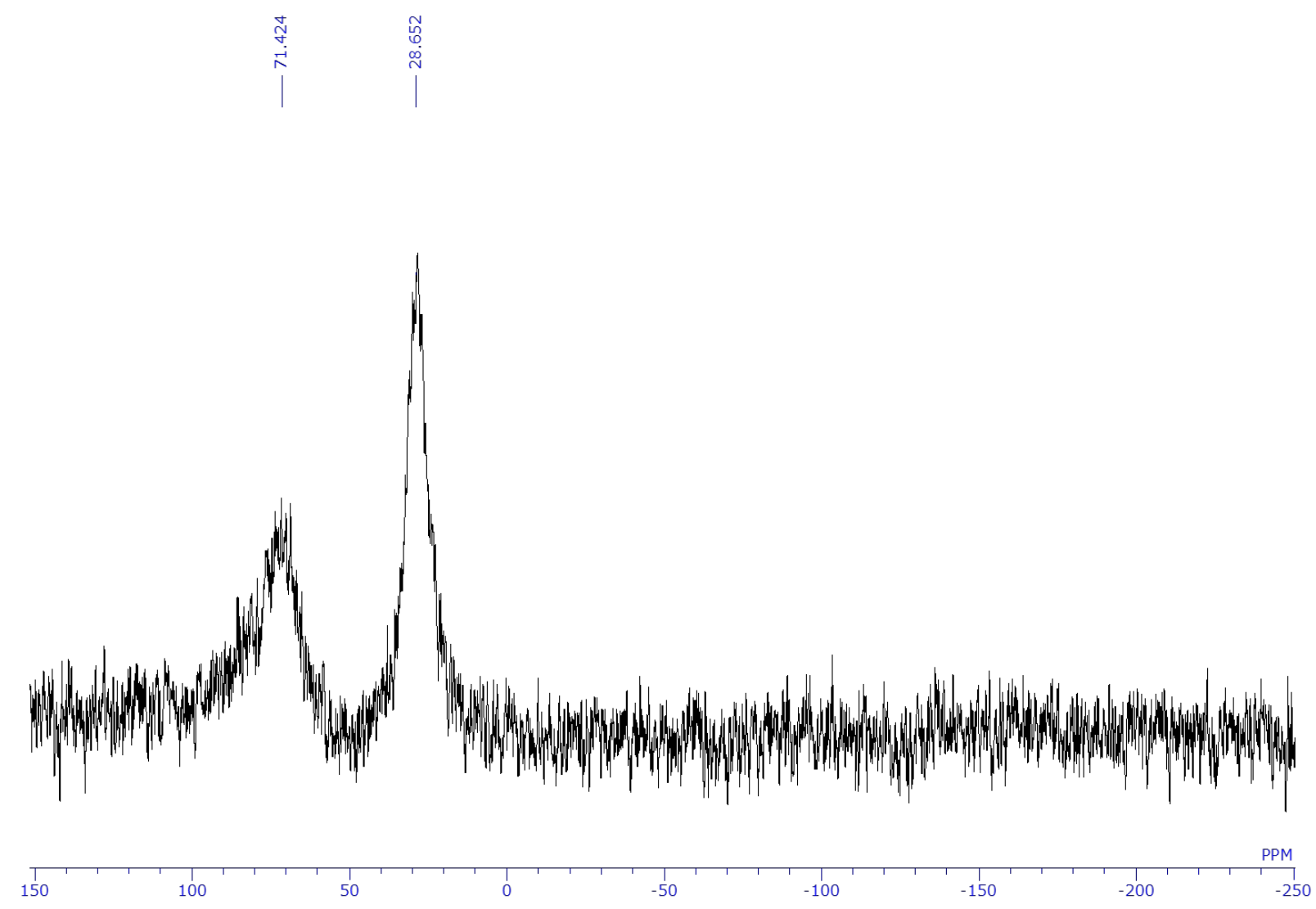

Figure S37. The ${ }^{11} \mathrm{~B}$ NMR spectrum $\left(\mathrm{C}_{6} \mathrm{D}_{6}\right)$ of $\mathbf{3 C b}$

\begin{tabular}{|c|c|c|c|}
\hline 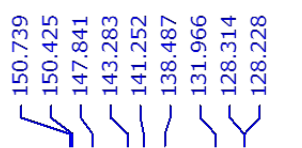 & 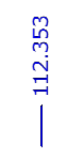 & 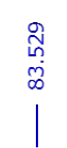 & $\begin{array}{l}\mathfrak{f} \\
\stackrel{H}{g} \\
g\end{array}$ \\
\hline
\end{tabular}

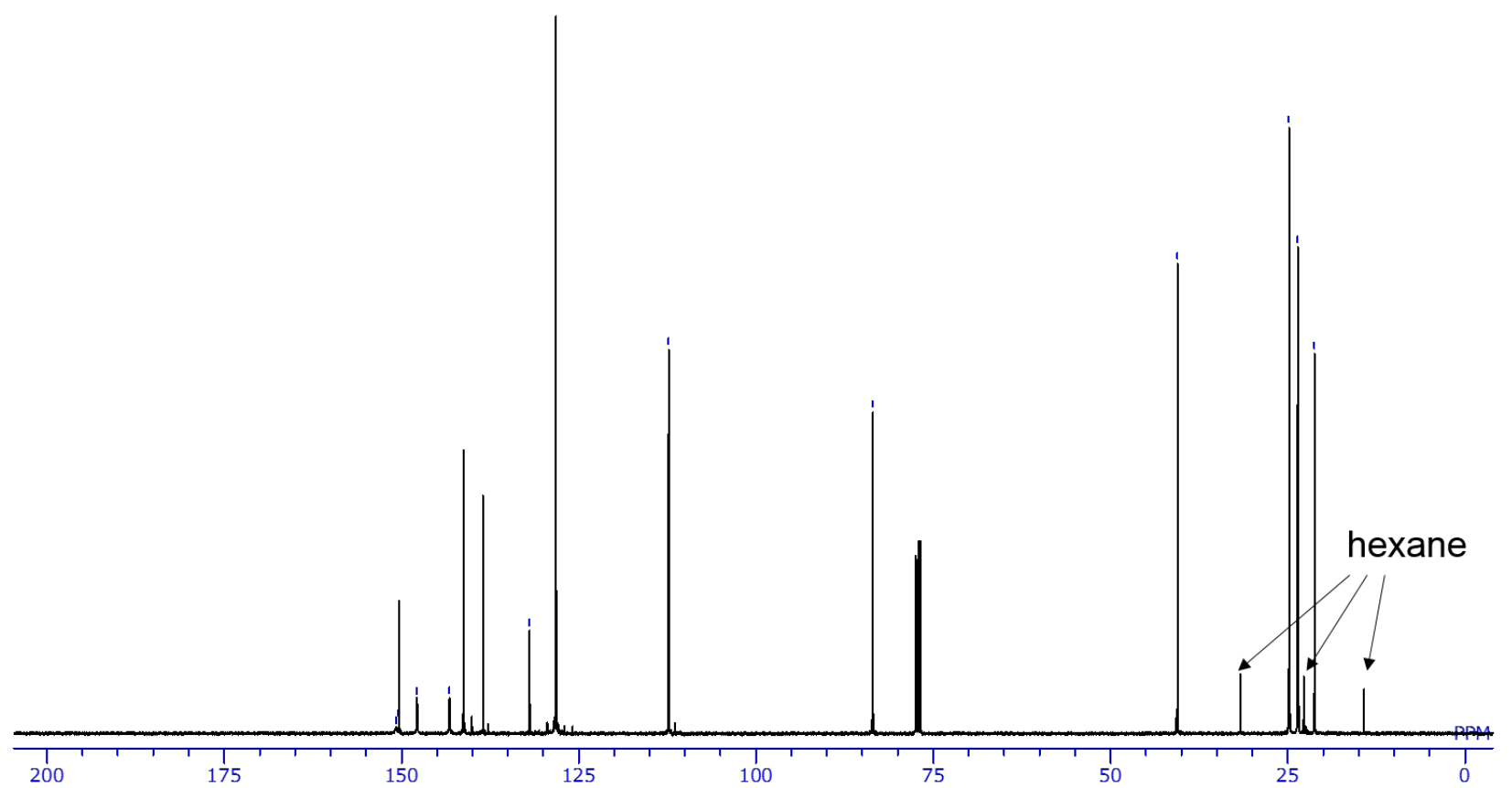

Figure S38. The ${ }^{13} \mathrm{C}$ NMR spectrum $\left(\mathrm{CDCl}_{3}\right)$ of $\mathbf{3 C b}$ 


\section{NMR yield of $3 \mathrm{Ca}$ and $3 \mathrm{Cb}$ in run 5 , Table 2}

The procedure described in run 1, Table 1 was used. Reaction condition: Toluene (500 $\mu \mathrm{L}), 1$ (75.5 mg, 0.201 mmol), 4-dimethylamino-phenylacetylene $(31.5 \mathrm{mg}, 0.217 \mathrm{mmol}), 100{ }^{\circ} \mathrm{C}, 6 \mathrm{~h}$, trimethoxybenzene $(18.4 \mathrm{mg}$, $0.1095 \mathrm{mmol}$ ), crude (108 mg); NMR yield: 3Ca, 24\%; 3Cb, 76\%. See Figure S39 for NMR spectrum of the crude product.

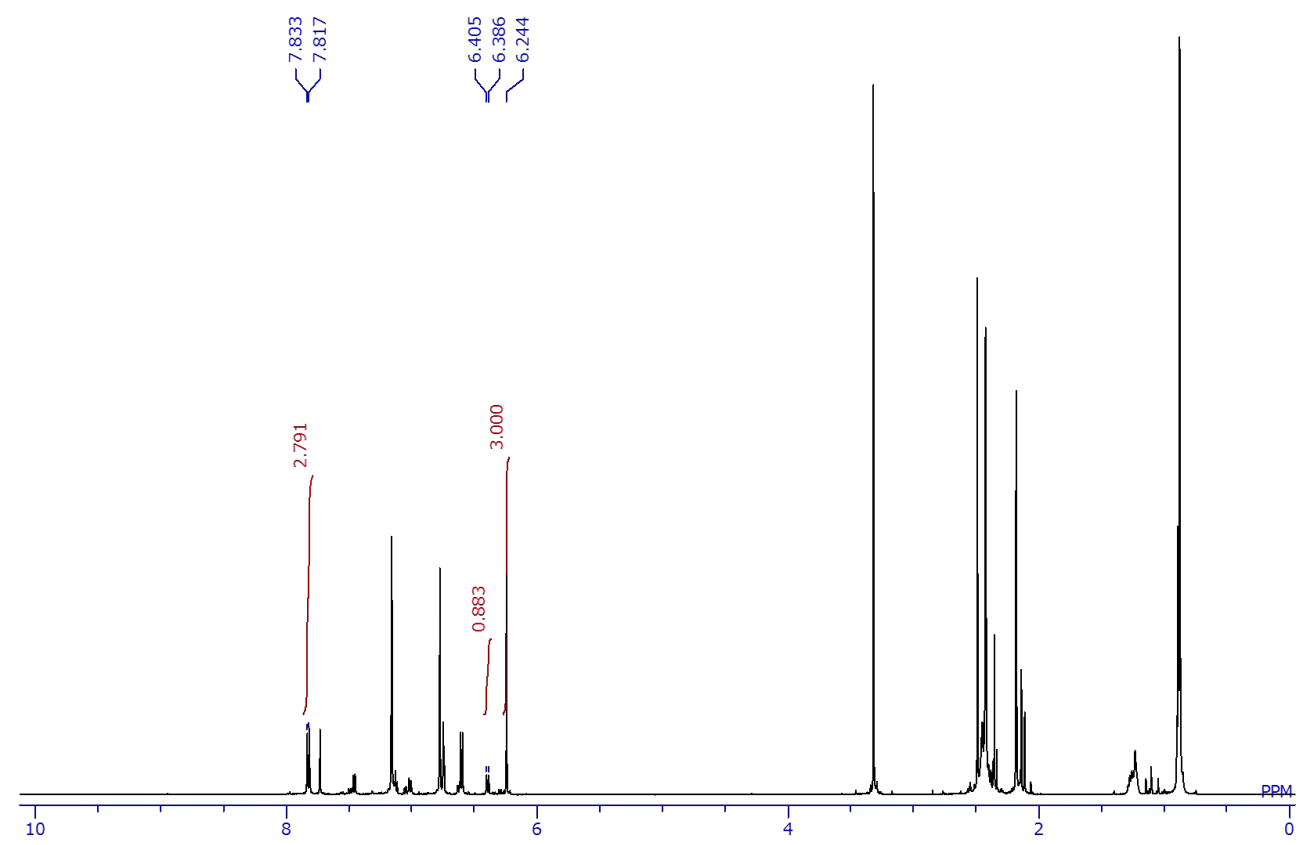

Figure S39. The ${ }^{1} \mathrm{H}$ NMR spectrum of the reaction mixture in run 5, Table $2(6.40 \mathrm{ppm}$ : 3Ca; 7.83 ppm: $\mathbf{3 C b}$; 6.24 ppm: internal standard, 1,3,5-trimethoxybenzene) 


\section{Base-catalyzed reaction of 1 with 4-dimethylaminophenylacetylene (Table 2, run 6)}

Because 3Cc was not isolated, the following NMR experiment was examined to afford a tentative assignment of 3Ce.

NMR yield of $3 \mathrm{Ca}, 3 \mathrm{Cb}$ and $3 \mathrm{Cc}$, in run 6 , Table 2

The procedure described in run 9, Table 1 was used. Reaction condition: Toluene $(500 \mu \mathrm{L}), \mathbf{1}(75.6 \mathrm{mg}, 0.201$ mmol), 4-dimethylaminophenylacetylene (32.0 mg, $0.220 \mathrm{mmol}){ }^{n} \mathrm{BuLi}(0.100 \mathrm{M}$ diluted in toluene, $60.0 \mu \mathrm{L}, 6.00$ $\mu \mathrm{mol})$, DME (0.100 M diluted in toluene, $60.0 \mu \mathrm{L}, 6.00 \mu \mathrm{mol}), 100{ }^{\circ} \mathrm{C}, 3 \mathrm{~h}$, trimethoxybenzene $(16.2 \mathrm{mg}, 96.4$ umol), crude (108.2 mg); NMR yield: 3Ca, 13\%; 3Cb, 41\%; 3Cc, 27\%. See Figure S40 for NMR spectrum of the crude product. In this reaction, $3 \mathrm{Cc}$ could not be completely isolated but was tentatively assigned.

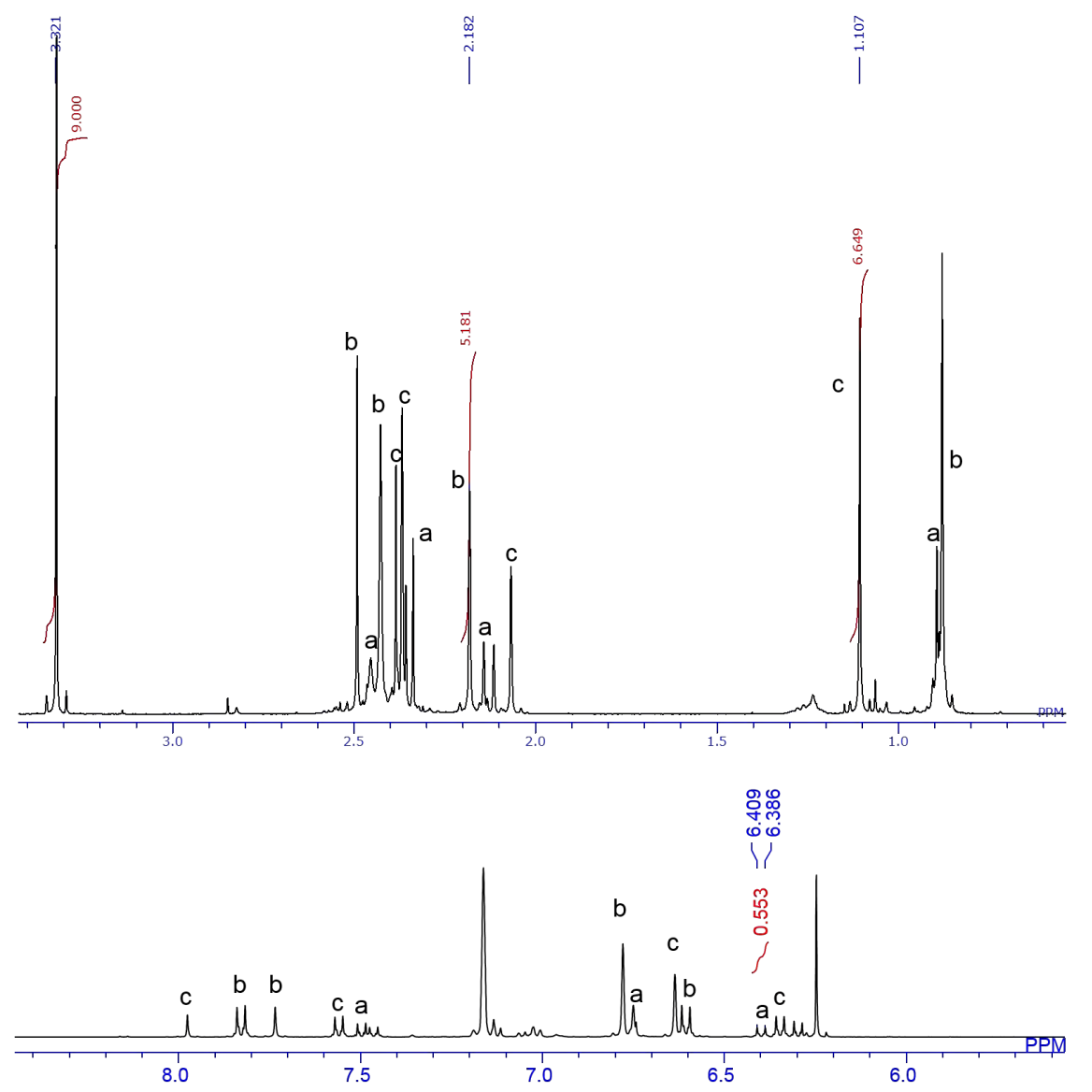

Figure S40. The ${ }^{1} \mathrm{H}$ NMR spectra (top: lower field, bottom: higher field) of the reaction mixture in run 6 , Table 2 (a, b, and c correspond to the signals of $\mathbf{3 C a}, \mathbf{3 C b}$, and $\mathbf{3 C c}$, which is tentatively assigned. $3.32 \mathrm{ppm}$ : internal standard, 1,3,5-trimethoxybenzene) 


\section{Direct reaction of 1 with 4-fluorophenylacetylene (Table 2, run 7)}

In a glovebox, to a toluene solution $(1.25 \mathrm{~mL})$ of $1(188 \mathrm{mg}, 0.500 \mathrm{mmol})$ in a $10 \mathrm{~mL} \mathrm{~J}$-young tube, 4-fluorophenyl-acetylene $(66.4 \mathrm{mg}, 0.552 \mathrm{mmol})$ was added. After stirring the reaction mixture at $100{ }^{\circ} \mathrm{C}$ for 3 days, volatiles were removed from the clear solution in vacuo. Purification of the residue by GPC (23 cycles) afforded pale yellow oils of 3Da (150.8 mg, $0.303 \mathrm{mmol}, 61 \%)$ and 3Db (68.0 mg, $0.137 \mathrm{mmol}, 27 \%)$. Single crystals of 3Da suitable for X-ray diffraction analysis were obtained by recrystallization from its hexane/THF (1:1, v/v) solution. 3Da: ${ }^{1} \mathrm{H}$ NMR $\left(400 \mathrm{MHz}, \mathrm{C}_{6} \mathrm{D}_{6}\right) \delta 0.86\left(\mathrm{~s}, 12 \mathrm{H}\right.$, pin- $\left.\mathrm{CH}_{3}\right), 2.12\left(\mathrm{~s}, 6 \mathrm{H}, p-\mathrm{CH}_{3}\right), 2.33\left(\mathrm{~s}, 12 \mathrm{H}, o-\mathrm{CH}_{3}\right)$, $6.52(\mathrm{~s}, 1 \mathrm{H}, \mathrm{CH}), 6.62$ (t, $J=9 \mathrm{~Hz}, 2 \mathrm{H}, \mathrm{ArH}), 6.71$ (s, 4H, ArH of Mes), 7.19 (q, $J=6 \mathrm{~Hz}, 2 \mathrm{H}, \mathrm{ArH}) ;{ }^{11} \mathrm{~B} \mathrm{NMR}$ (128 MHz, $\left.\mathrm{CD}_{2} \mathrm{Cl}_{2}\right) \delta 29$ (br s), 74 (br s); $\left.{ }^{13} \mathrm{C} \mathrm{NMR} \mathrm{(101} \mathrm{MHz,} \mathrm{CD}_{2} \mathrm{Cl}_{2}\right) \delta 21.4\left(\mathrm{CH}_{3}\right), 23.8\left(\mathrm{CH}_{3}\right), 24.6\left(\mathrm{CH}_{3}\right)$, $83.8\left(4^{\circ}\right), 115.1(\mathrm{~d}, \mathrm{CH}), 129.0(\mathrm{CH}), 129.6(\mathrm{~d}, \mathrm{CH}), 133.4\left(\mathrm{br}, \mathrm{CH}\right.$, bonding to the B nucleus), $139.9\left(4^{\circ}\right), 142.0$ $\left(4^{\circ}\right), 143.6\left(4^{\circ}\right.$, bonding to the B nucleus), $161.3\left(4^{\circ}\right), 163.7\left(4^{\circ}\right), 169.2\left(\mathrm{br}, 4^{\circ}\right.$, bonding to the B nucleus); mp 149-150 ${ }^{\circ} \mathrm{C}$; HRMS (ESI+) Calcd for $\mathrm{C}_{32} \mathrm{H}_{39} \mathrm{~B}_{2} \mathrm{FO}_{2}$ : 496.3120, found: 496.3139; 3Db: ${ }^{1} \mathrm{H}$ NMR $\left(400 \mathrm{MHz}, \mathrm{C}_{6} \mathrm{D}_{6}\right)$ $\delta 0.80\left(\mathrm{~s}, 12 \mathrm{H}\right.$, pin- $\left.\mathrm{CH}_{3}\right), 2.17\left(\mathrm{~s}, 6 \mathrm{H}, p-\mathrm{CH}_{3}\right), 2.36\left(\mathrm{~s}, 12 \mathrm{H}, o-\mathrm{CH}_{3}\right), 6.77(\mathrm{~s}, 4 \mathrm{H}, \mathrm{ArH}$ of Mes $), 6.87(\mathrm{t}, J=9 \mathrm{~Hz}$, $2 \mathrm{H}, \mathrm{ArH}), 7.49$ (s, 1H, CH), 7.55 (q, $J=6,2 \mathrm{H}, \mathrm{ArH})$; HRMS (ESI+) Calcd for $\mathrm{C}_{32} \mathrm{H}_{39} \mathrm{~B}_{2} \mathrm{FO}_{2}$ : 496.3120, found: 496.3113 .
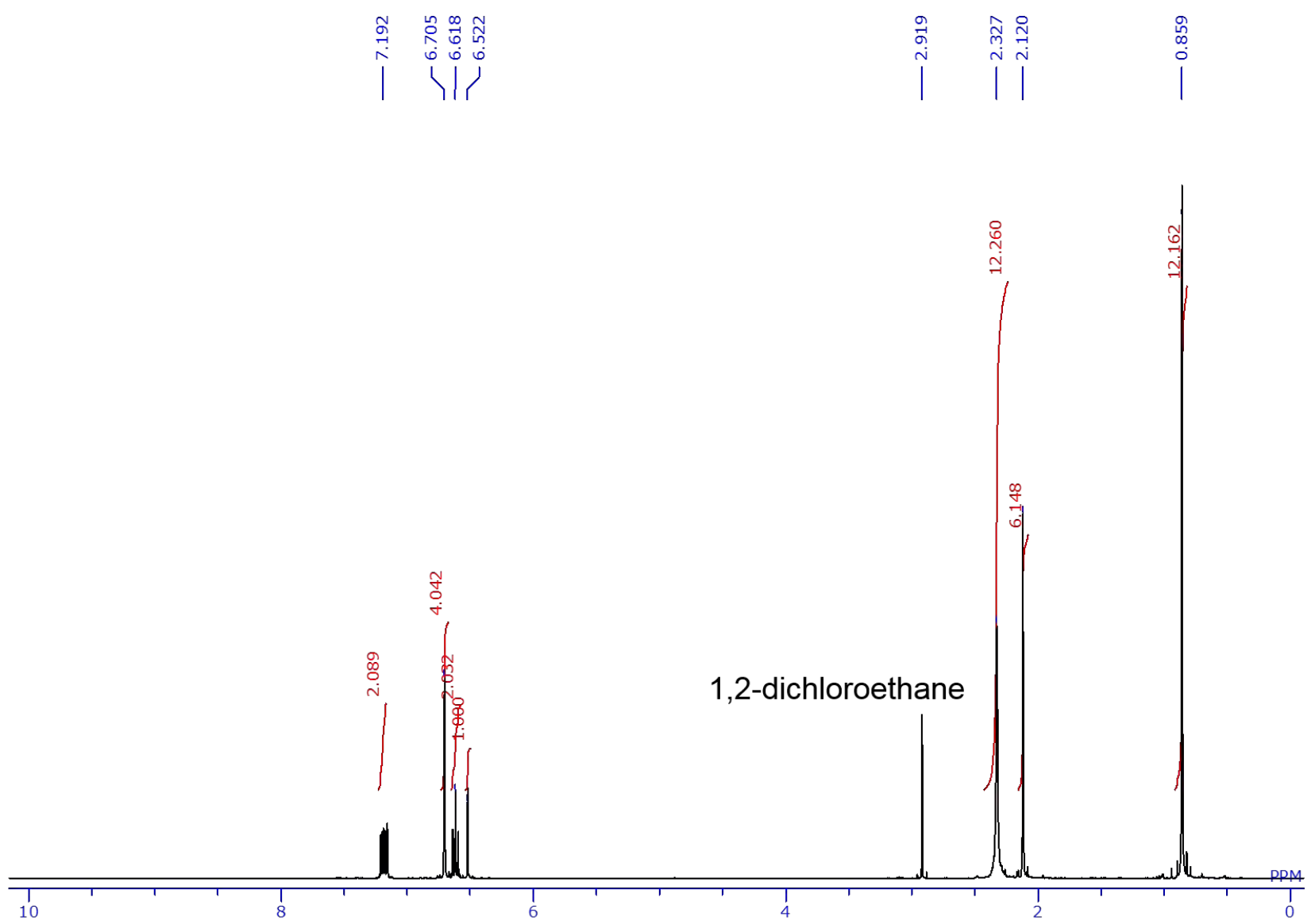

Figure S41. The ${ }^{1} \mathrm{H}$ NMR spectrum $\left(\mathrm{C}_{6} \mathrm{D}_{6}\right)$ of $\mathbf{3 D a}$ 


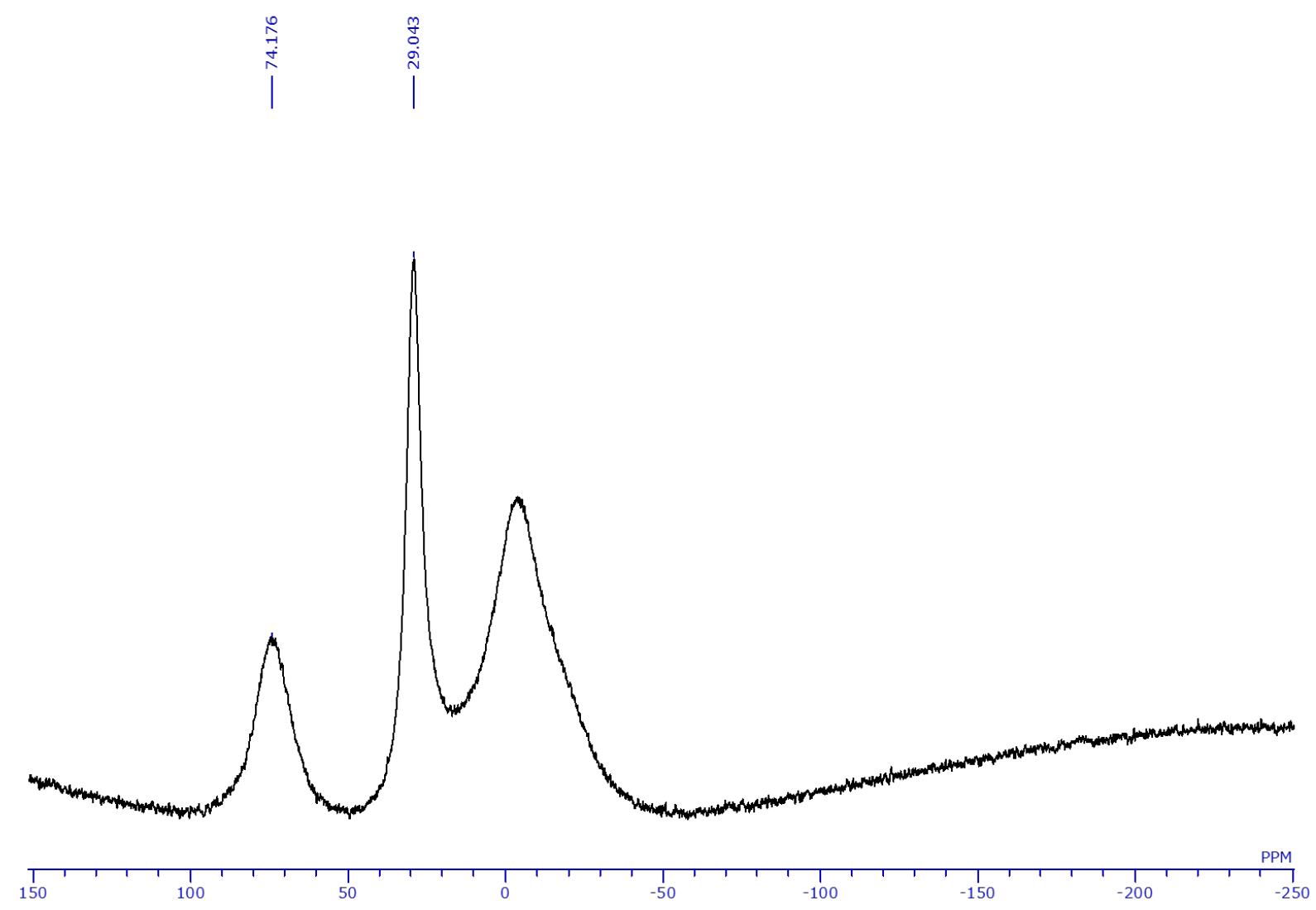

Figure S42. The ${ }^{11} \mathrm{~B}$ NMR spectrum (borosilicate NMR tube, $\mathrm{CD}_{2} \mathrm{Cl}_{2}$ ) of $3 \mathrm{Da}$

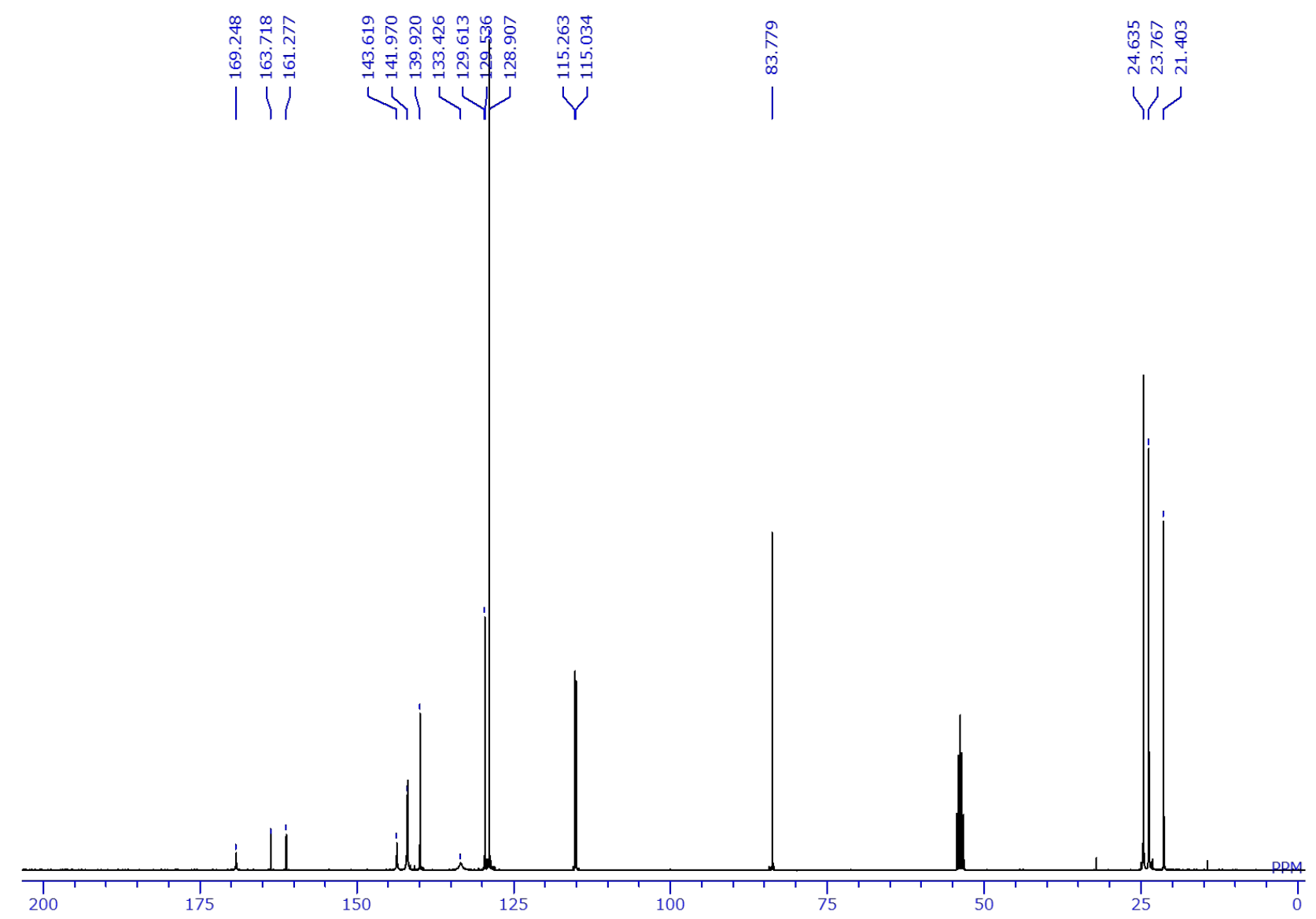

Figure S43. The ${ }^{13} \mathrm{C}$ NMR spectrum $\left(\mathrm{CD}_{2} \mathrm{Cl}_{2}\right)$ of 3Da 


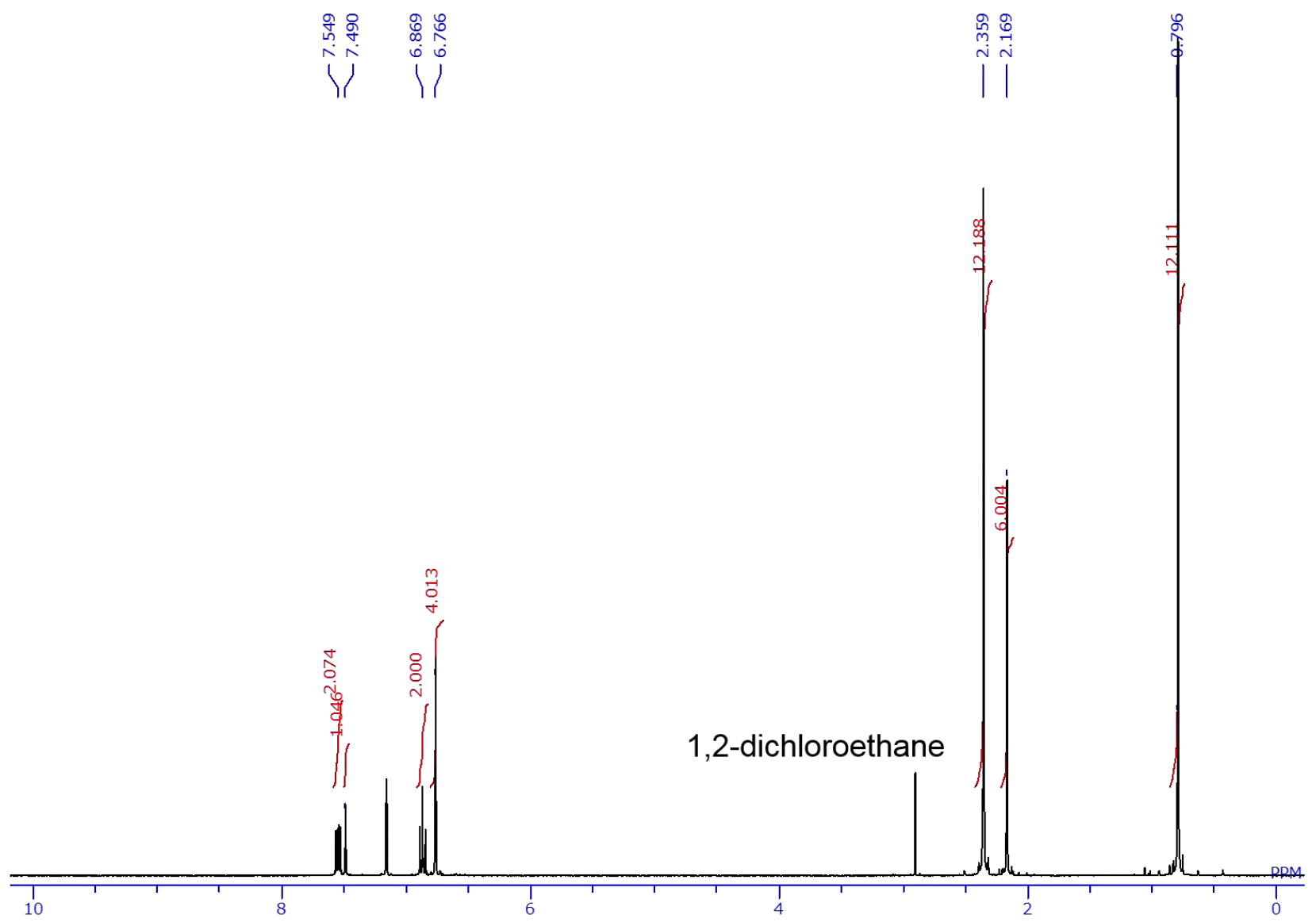

Figure S44. The ${ }^{1} \mathrm{H}$ NMR spectrum $\left(\mathrm{C}_{6} \mathrm{D}_{6}\right)$ of $\mathbf{3 D b}$

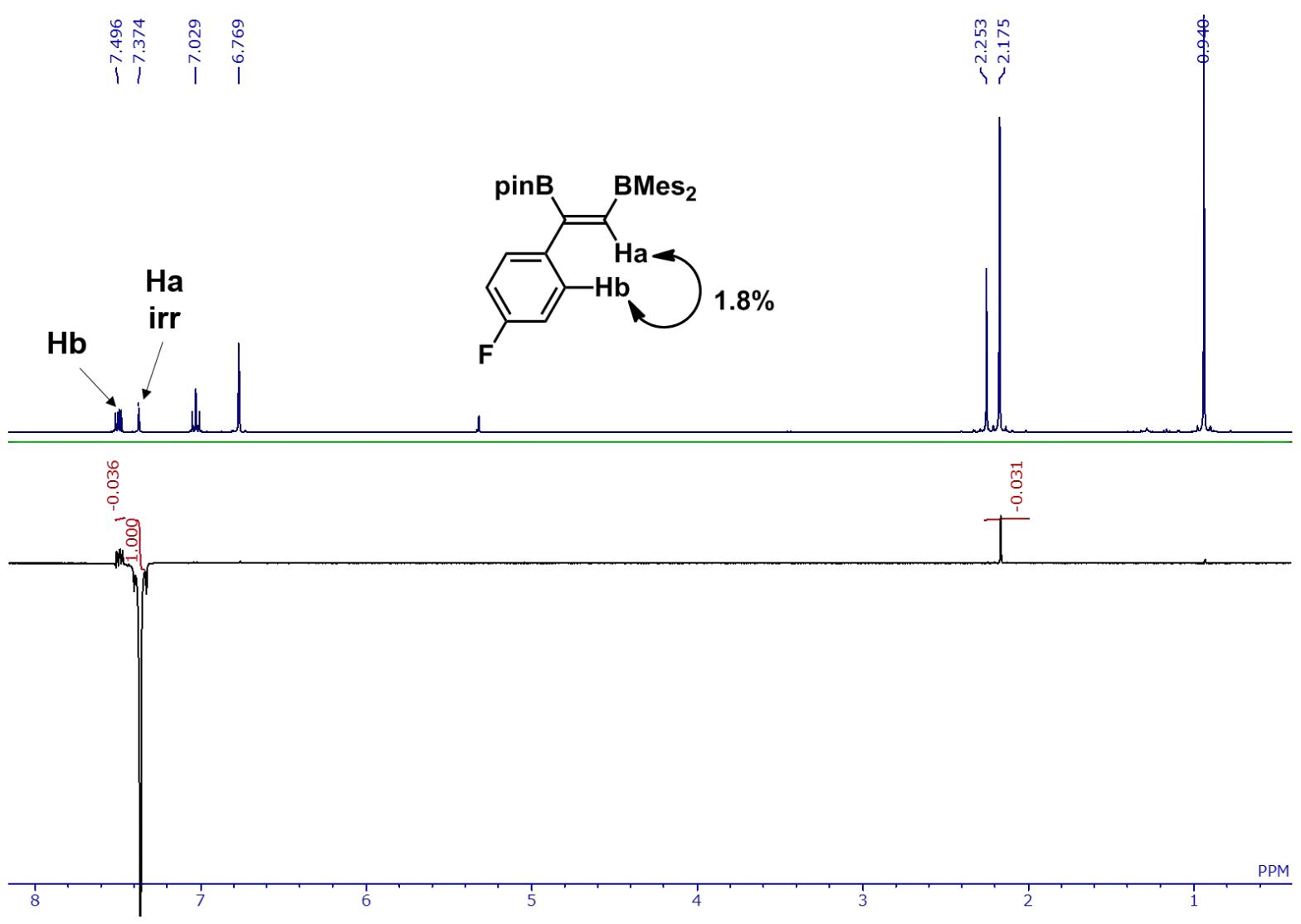

Figure S45. The differential ${ }^{1} \mathrm{H}$ NOE spectrum $\left(\mathrm{C}_{6} \mathrm{D}_{6}\right)$ of $\mathbf{3 D b}$ with irradiation to the signal of vinylic $\mathrm{H}_{\mathrm{a}}$ 


\section{NMR yield of 3Da and 3Db in run 7, Table 2}

The procedure described in run 1, Table 1 was used. Reaction condition: Toluene (500 $\mu \mathrm{L}), 1$ (75.2 mg, 0.200 mmol), 4-fluorophenyl-acetylene $(27.0 \mathrm{mg}, 0.225 \mathrm{mmol}), 100{ }^{\circ} \mathrm{C}, 67 \mathrm{~h}$, trimethoxybenzene $(20.6 \mathrm{mg}, 0.123$ mmol), crude (102 mg); NMR yield: 3Da, 66\%; 3Db, 30\%. See Figure S46 for NMR spectrum of the crude product.

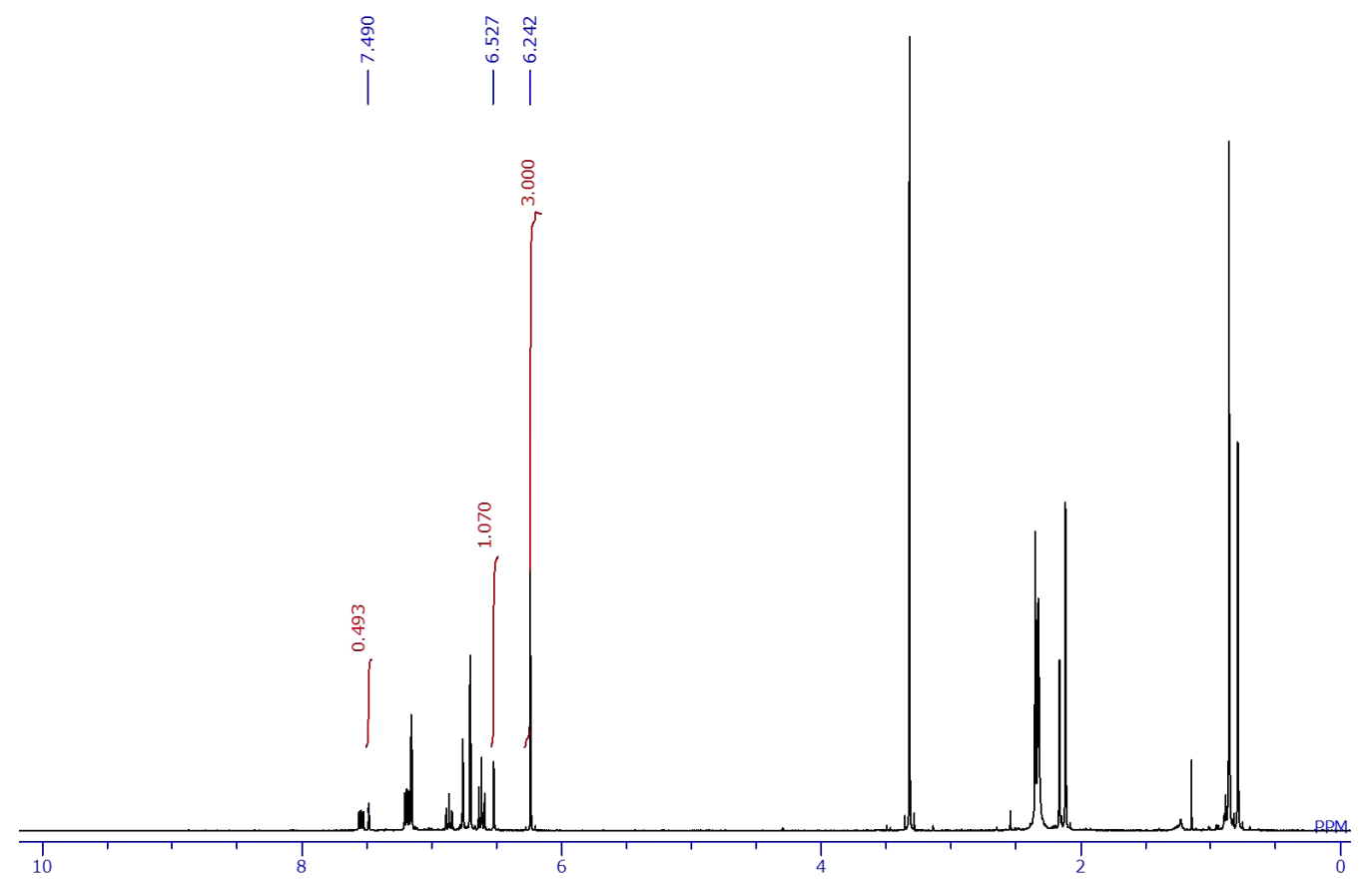

Figure S46. The ${ }^{1} \mathrm{H}$ NMR spectrum of the reaction mixture in run 7, Table 2 (6.53 ppm: 3Da; 7.49 ppm: 3Db; 6.24 ppm: internal standard, 1,3,5-trimethoxybenzene) 


\section{Base-catalyzed reaction of 1 with 4-fluorophenylacetylene (Table 2, run 8)}

In a glovebox, to a solution of 4-fluorophenyl-acetylene $(67.2 \mathrm{mg}, 0.559 \mathrm{mmol})$ in toluene $(1.25 \mathrm{~mL}),{ }^{n} \mathrm{BuLi}$ $(0.100 \mathrm{M}$ diluted in toluene, $150 \mu \mathrm{L}, 15.0 \mu \mathrm{mol})$ was added dropwise at room temperature. After stirring the reaction mixture at room temperature for $3 \mathrm{~min}, 1(188.2 \mathrm{mg}, 0.500 \mathrm{mmol})$ and DME $(0.100 \mathrm{M}$ diluted in toluene, $150 \mu \mathrm{L}, 15.0 \mu \mathrm{mol})$ were added to the reaction mixture at room temperature. After the reaction mixture stirred at $100{ }^{\circ} \mathrm{C}$ for $5 \mathrm{~h}$, volatiles were removed from the pale yellow solution in vacuo. The residue was triturated with hexane and the resulting suspension was filtered through a pad of Celite. After volatiles were removed from the filtrate in vacuo, the residue was purified by recycling GPC (7 cycles) afforded yellow oil of 3Dc (101 mg, 0.204 mmol, 41\%). Single crystals of 3Dc suitable for X-ray diffraction analysis were obtained by slow evaporation of its hexane solution to the coexistent silica-gel in a capped vial at room temperature. 3Dc: ${ }^{1} \mathrm{H}$ NMR (400 MHz, $\left.\mathrm{C}_{6} \mathrm{D}_{6}\right) \delta 1.06\left(\mathrm{~s}, 12 \mathrm{H}\right.$, pin- $\left.\mathrm{CH}_{3}\right), 2.08\left(\mathrm{~s}, 6 \mathrm{H}, p-\mathrm{CH}_{3}\right), 2.24\left(\mathrm{~s}, 12 \mathrm{H}, o-\mathrm{CH}_{3}\right), 6.56$ (s, 4H, ArH of Mes), 6.62 (t, $J=9$ $\mathrm{Hz}, 2 \mathrm{H}, \mathrm{ArH}), 7.29$ (q, $J=6 \mathrm{~Hz}, 2 \mathrm{H}, \mathrm{ArH}), 8.09$ (s, $1 \mathrm{H}, \mathrm{CH}) ;{ }^{11} \mathrm{~B} \mathrm{NMR}\left(128 \mathrm{MHz}, \mathrm{CD}_{2} \mathrm{Cl}_{2}\right.$ ) $\delta 30$ (br s), 74 (br s); ${ }^{13} \mathrm{C}$ NMR $\left(101 \mathrm{MHz}, \mathrm{CD}_{2} \mathrm{Cl}_{2}\right)$ \& $21.3\left(\mathrm{CH}_{3}\right), 23.6\left(\mathrm{CH}_{3}\right), 25.0\left(\mathrm{CH}_{3}\right), 24.4\left(\mathrm{CH}_{3}\right), 84.5\left(4^{\circ}\right), 113.8(\mathrm{~d}, \mathrm{CH})$, 128.7(CH), $130.0(\mathrm{~d}, \mathrm{CH}), 139.2\left(4^{\circ}\right), 140.3\left(4^{\circ}\right), 142.8\left(4^{\circ}\right.$, bonding to the B nucleus), $149.7\left(\mathrm{br}, 4^{\circ}\right.$, bonding to the $\mathrm{B}$ nucleus), 156.5 (br, $\mathrm{CH}$, bonding to the $\mathrm{B}$ nucleus), $161.0\left(4^{\circ}\right), 163.5\left(4^{\circ}\right)$; mp $138-140{ }^{\circ} \mathrm{C}$ (decomp.); HRMS (ESI+) Calcd for $\mathrm{C}_{32} \mathrm{H}_{39} \mathrm{~B}_{2} \mathrm{FO}_{2}: 496.3120$, found: 496.3101 .

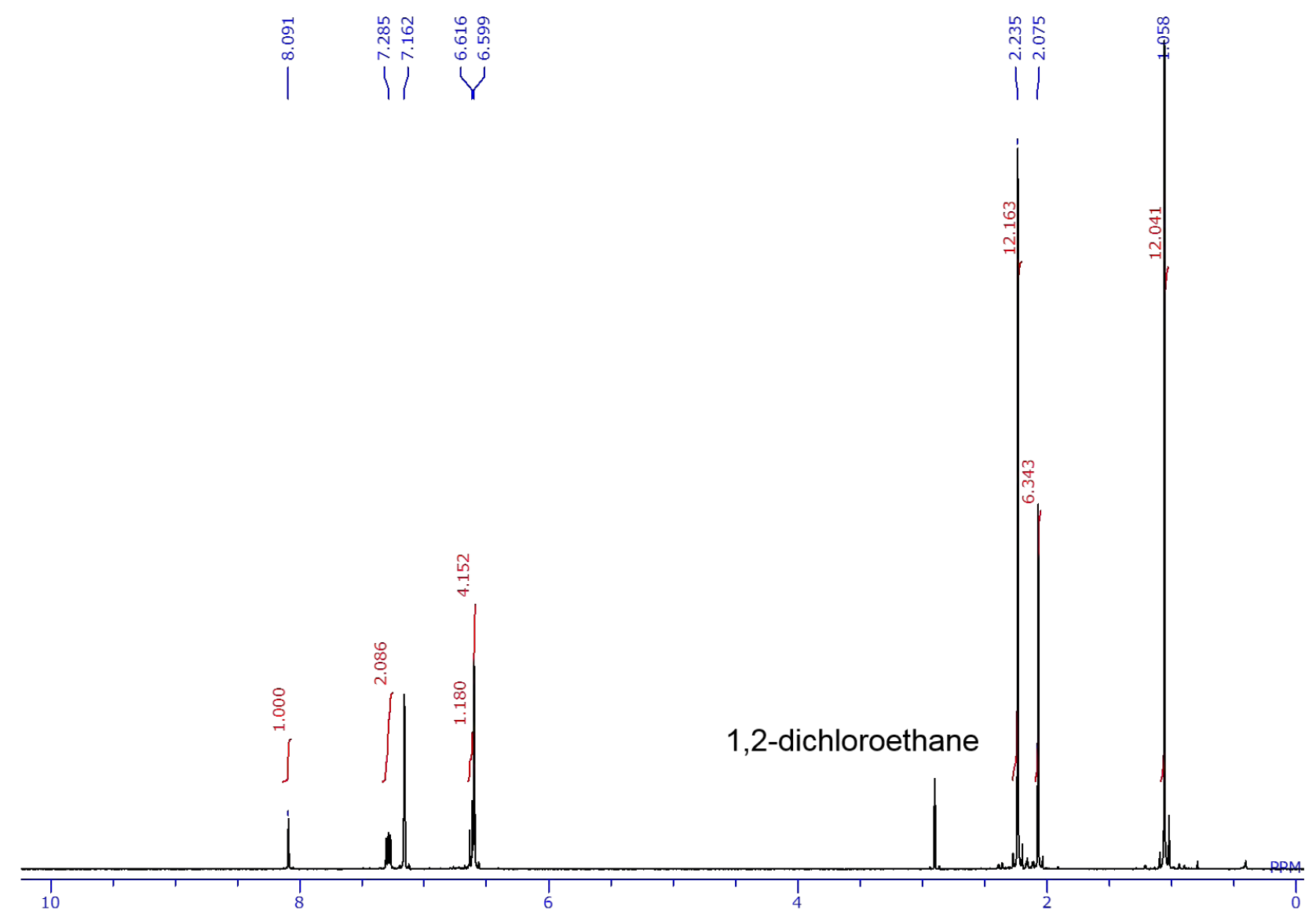

Figure S47. The ${ }^{1} \mathrm{H}$ NMR spectrum $\left(\mathrm{C}_{6} \mathrm{D}_{6}\right)$ of 3 Dc 


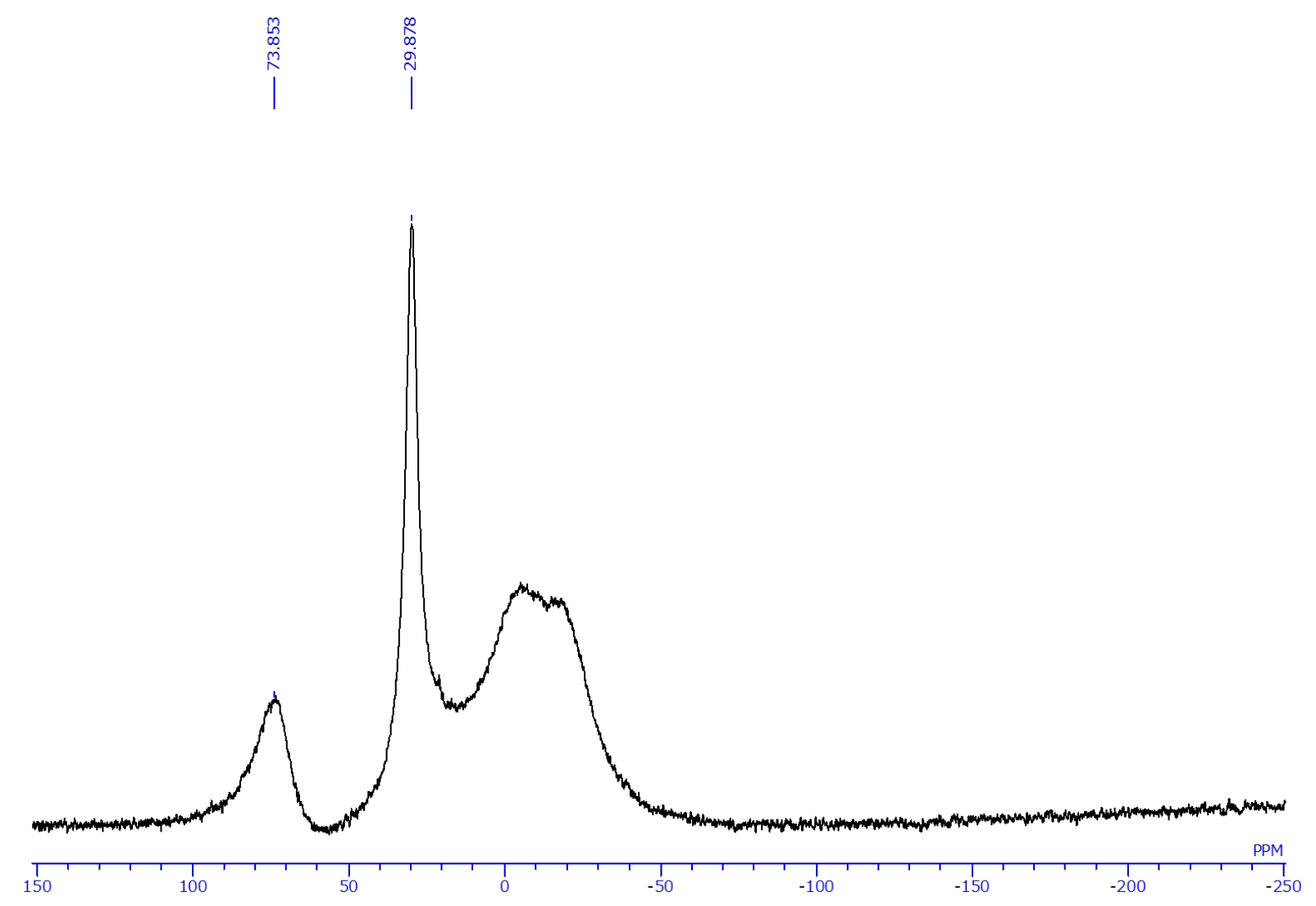

Figure S48. The ${ }^{11} \mathrm{~B}$ NMR spectrum (borosilicate NMR tube, $\mathrm{CD}_{2} \mathrm{Cl}_{2}$ ) of $\mathbf{3 D c}$

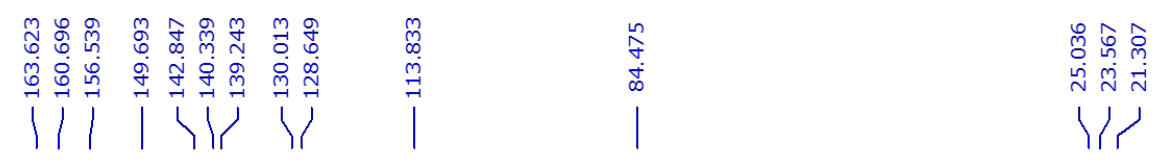

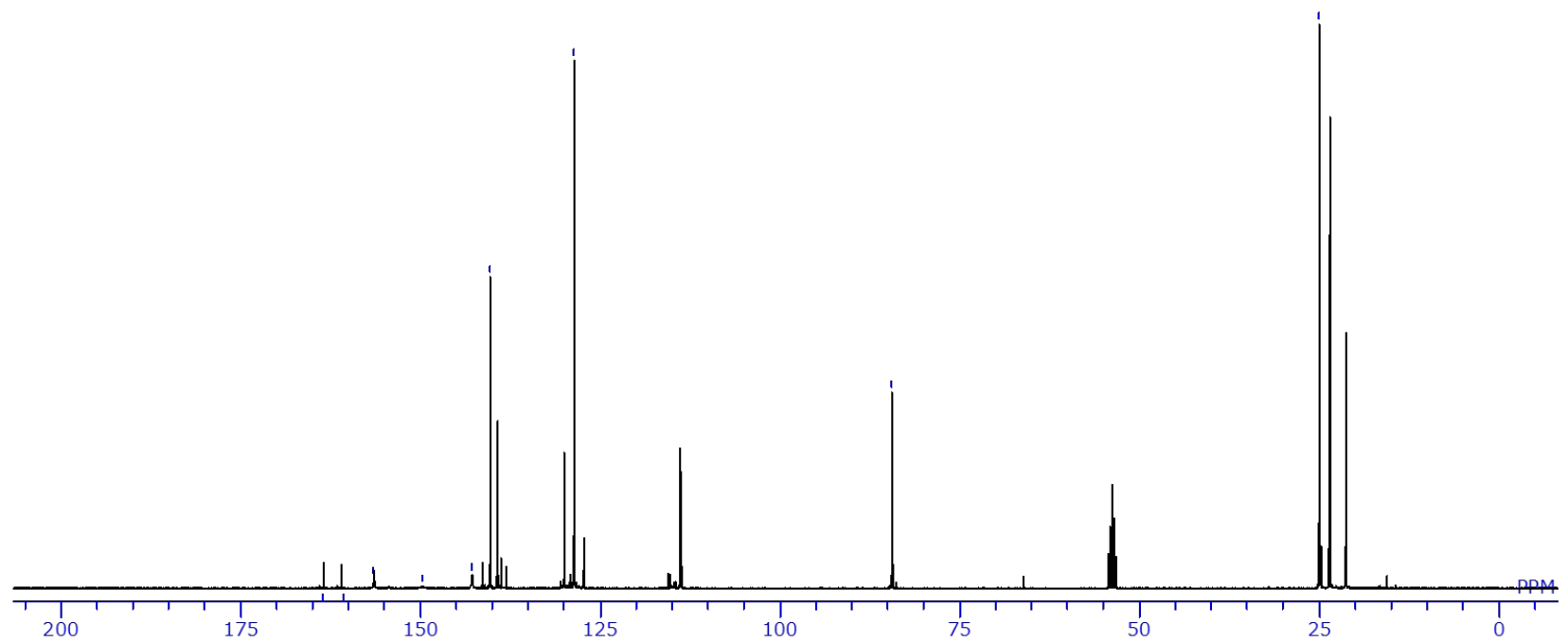

Figure S49. The ${ }^{13} \mathrm{C}$ NMR spectrum $\left(\mathrm{CD}_{2} \mathrm{Cl}_{2}\right)$ of $3 \mathrm{Dc}$ 
NMR yield of 3Da, 3Db and 3Dc, in run 8, Table 2

The procedure described in run 9, Table 1 was used. Reaction condition: Toluene $(500 \mu L), 1$ (75.6 mg, 0.201 $\mathrm{mmol})$, 4-fluorophenyl-acetylene $(26.4 \mathrm{mg}, 0.220 \mathrm{mmol}),{ }^{n} \mathrm{BuLi}(0.100 \mathrm{M}$ diluted in toluene, $60.0 \mu \mathrm{L}, 6.00 \mu \mathrm{mol})$, $\operatorname{DME}(0.100 \mathrm{M}$ diluted in toluene, $60.0 \mu \mathrm{L}, 6.00 \mu \mathrm{mol}), 100{ }^{\circ} \mathrm{C}, 5 \mathrm{~h}$, trimethoxybenzene $(10.1 \mathrm{mg}, 0.0601 \mathrm{mmol})$, crude $(96.8 \mathrm{mg})$; NMR yield: 3Da, 16\%; 3Db, 12\%; 3Dc, 53\%. See Figure S50 for NMR spectrum of the crude product.

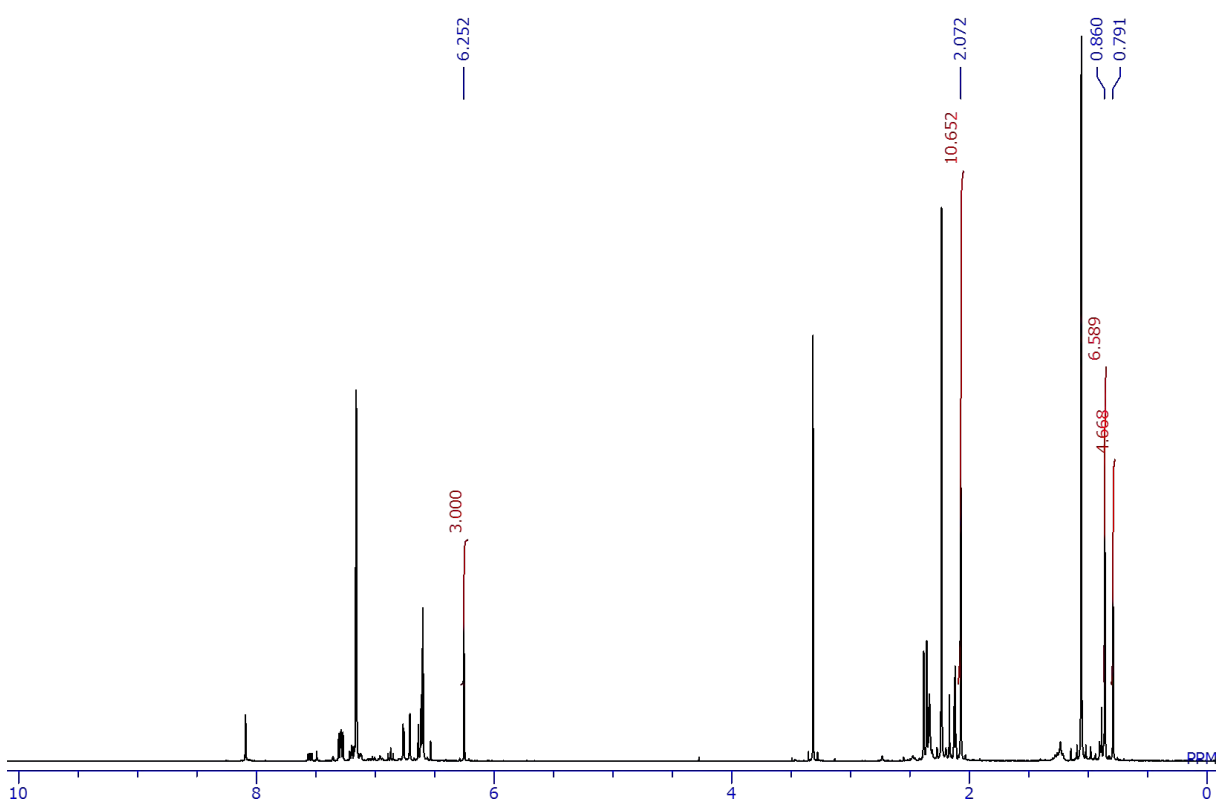

Figure S50. The ${ }^{1} \mathrm{H}$ NMR spectrum of the reaction mixture in run 8 , Table 2 (0.86 ppm: 3Da; 0.79 ppm: 3Db; 2.07 ppm: 3Dc; 6.25 ppm: internal standard, 1,3,5-trimethoxybenzene) 


\section{Direct reaction of 1 with 4-trifluoromethylphenylacetylene (Table 2, run 9)}

In a glovebox, to a toluene solution $(500 \mu \mathrm{L})$ of $1(188 \mathrm{mg}, 0.500 \mathrm{mmol})$ in a $10 \mathrm{~mL}$ J-young tube, 4-trifluoromethylphenylacetylene $(79.1 \mu \mathrm{L}, 0.550 \mathrm{mmol})$ was added. After stirring the reaction mixture at $100{ }^{\circ} \mathrm{C}$ for $59 \mathrm{~h}$, volatiles were removed from the clear solution in vacuo. Purification of the residue by GPC (19 cycles) afforded pale yellow oils of 3Ea (108.9 mg, $0.199 \mathrm{mmol}, 40 \%)$ and 3Eb (30.5 mg, $0.0558 \mathrm{mmol}, 11 \%)$. Single crystals of 3Ea suitable for X-ray diffraction analysis were obtained by recrystallization from its hexane solution. 3Ea: ${ }^{1} \mathrm{H}$ NMR (400 MHz, $\left.\mathrm{C}_{6} \mathrm{D}_{6}\right) \delta 0.85\left(\mathrm{~s}, 12 \mathrm{H}, \mathrm{pin}-\mathrm{CH}_{3}\right), 2.11\left(\mathrm{~s}, 6 \mathrm{H}, p-\mathrm{CH}_{3}\right), 2.27\left(\mathrm{~s}, 12 \mathrm{H}, o-\mathrm{CH}_{3}\right), 6.50(\mathrm{~s}, 1 \mathrm{H}$, $\mathrm{CH}), 6.69$ (s, 4H, ArH of Mes), 7.15 (d, $J=9 \mathrm{~Hz}, 2 \mathrm{H}, \mathrm{ArH}), 7.23$ (d, $J=9 \mathrm{~Hz}, 2 \mathrm{H}, \mathrm{ArH}) ;{ }^{11} \mathrm{~B} \mathrm{NMR}(128 \mathrm{MHz}$, $\left.\mathrm{CD}_{2} \mathrm{Cl}_{2}\right) \delta 30$ (br s), 76 (br s); ${ }^{13} \mathrm{C}$ NMR (101 MHz, $\left.\mathrm{CD}_{2} \mathrm{Cl}_{2}\right) \delta 21.4\left(\mathrm{CH}_{3}\right), 23.8\left(\mathrm{CH}_{3}\right), 24.7\left(\mathrm{CH}_{3}\right), 83.9\left(4^{\circ}\right)$, $123.6\left(4^{\circ}\right), 125.4(\mathrm{q}, \mathrm{CF} 3), 126.3\left(4^{\circ}\right), 128.2(\mathrm{CH}), 129.0(\mathrm{CH}), 135.8(\mathrm{br}, \mathrm{CH}$, bonding to the $\mathrm{B}$ nucleus), 140.0 $\left(4^{\circ}\right), 142.0$ (br, $4^{\circ}$, bonding to the B nucleus), $143.4\left(4^{\circ}\right), 149.6\left(4^{\circ}\right), 169.0\left(4^{\circ}\right.$, bonding to the B nucleus); mp 148-150 ${ }^{\circ} \mathrm{C}$; HRMS (ESI+) Calcd for $\mathrm{C}_{33} \mathrm{H}_{39} \mathrm{~B}_{2} \mathrm{~F}_{3} \mathrm{O}_{2}$ : 546.3088, found: 546.3113; 3Eb: ${ }^{1} \mathrm{H}$ NMR (400 MHz, $\left.\mathrm{C}_{6} \mathrm{D}_{6}\right) \delta 0.79\left(\mathrm{~s}, 12 \mathrm{H}\right.$, pin- $\left.\mathrm{CH}_{3}\right), 2.17$ (s, 6H, $\left.p-\mathrm{CH}_{3}\right), 2.35$ (s, 12H, o- $\left.\mathrm{CH}_{3}\right), 6.77$ (s, 4H, ArH of Mes), 7.41 (d, $J=9$ $\mathrm{Hz}, 2 \mathrm{H}, \mathrm{ArH}), 7.51(\mathrm{~s}, 1 \mathrm{H}, \mathrm{CH}), 7.56(\mathrm{~d}, J=9,2 \mathrm{H}, \mathrm{ArH})$; HRMS (ESI+) Calcd for $\mathrm{C}_{33} \mathrm{H}_{39} \mathrm{~B}_{2} \mathrm{~F}_{3} \mathrm{O}_{2}: 546.3088$, found: 546.3063 .
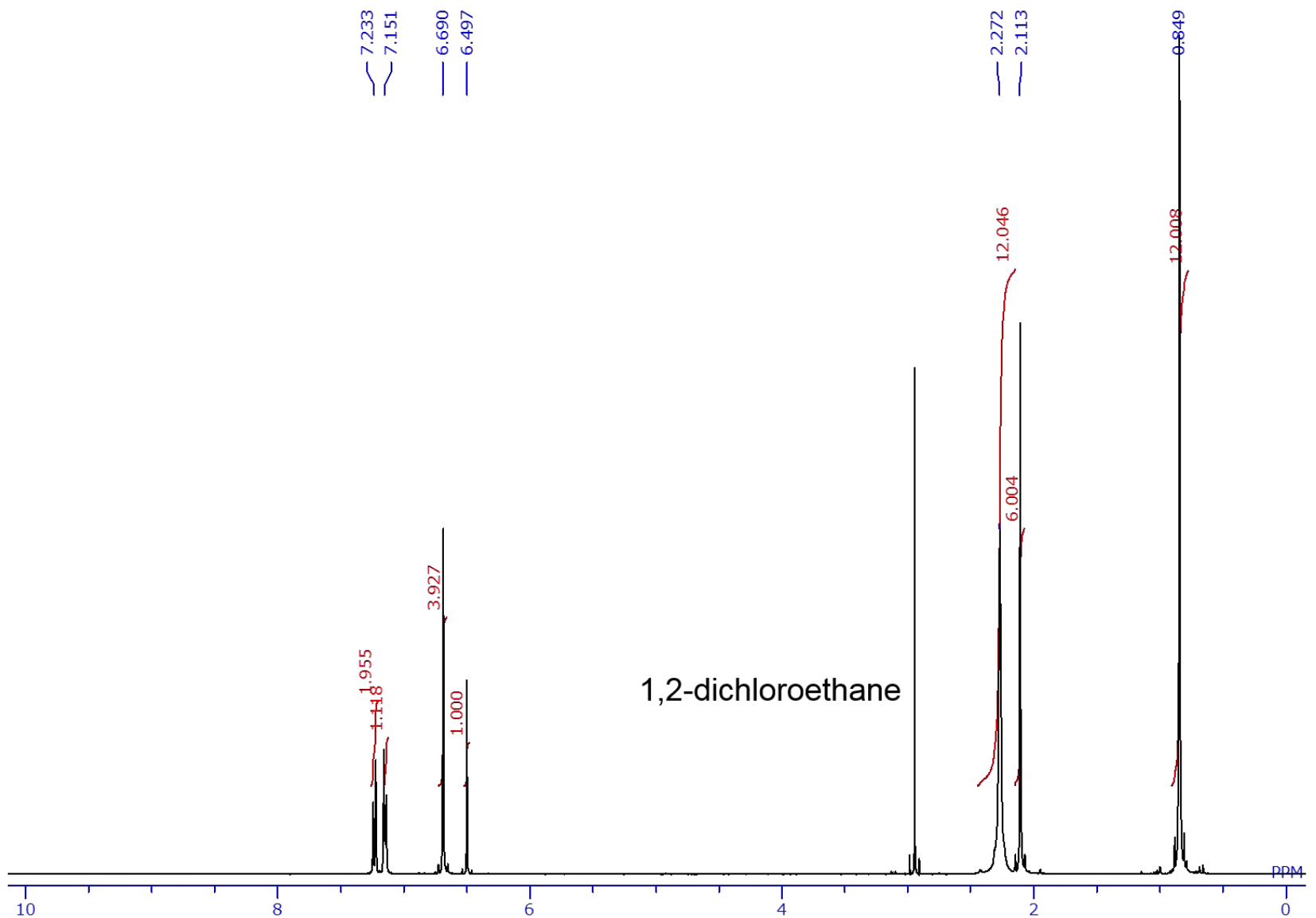

Figure S51. The ${ }^{1} \mathrm{H}$ NMR spectrum $\left(\mathrm{C}_{6} \mathrm{D}_{6}\right)$ of $\mathbf{3 E a}$ 


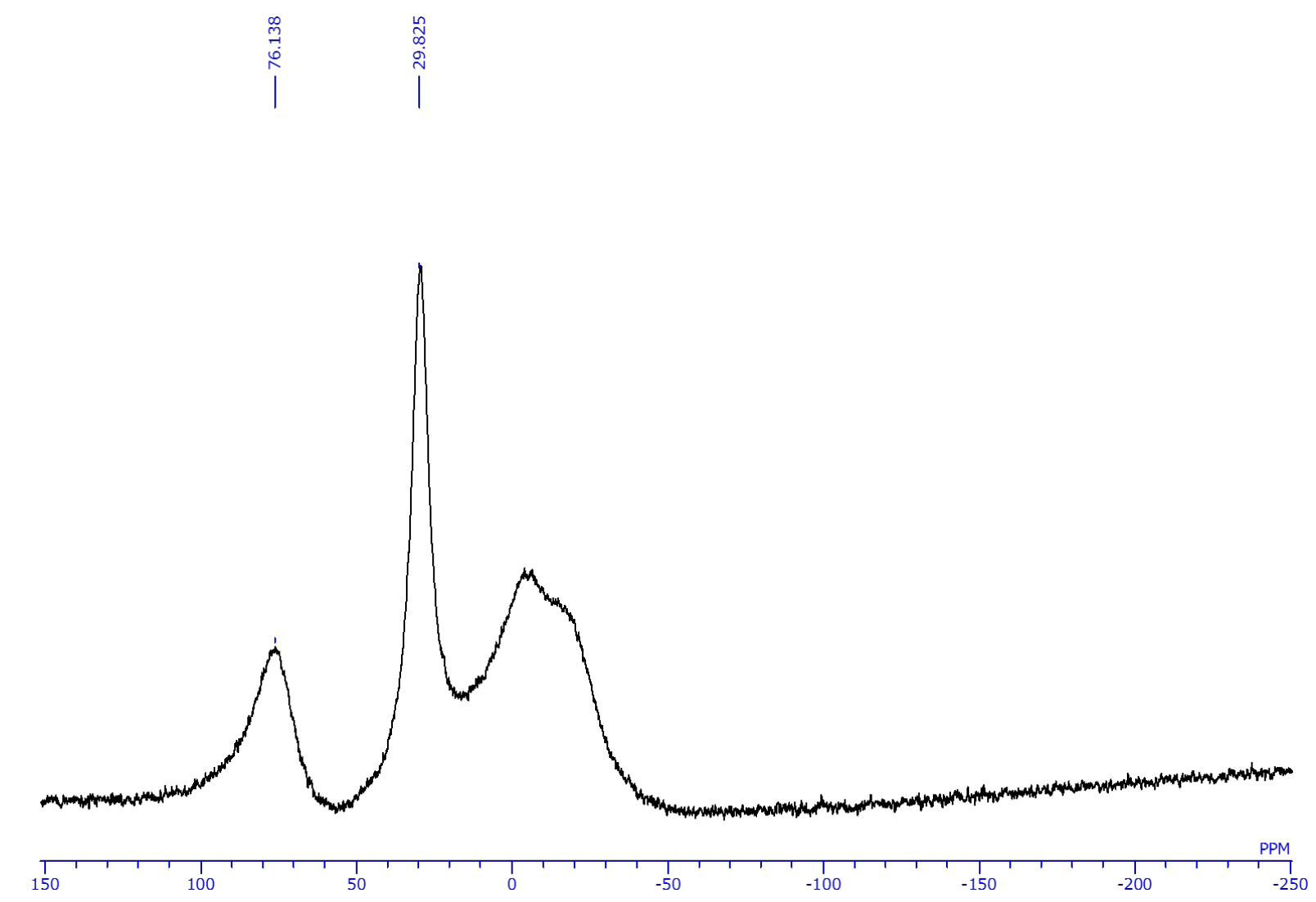

Figure S52. The ${ }^{11} \mathrm{~B}$ NMR spectrum (borosilicate NMR tube, $\mathrm{CD}_{2} \mathrm{Cl}_{2}$ ) of $\mathbf{3 E a}$

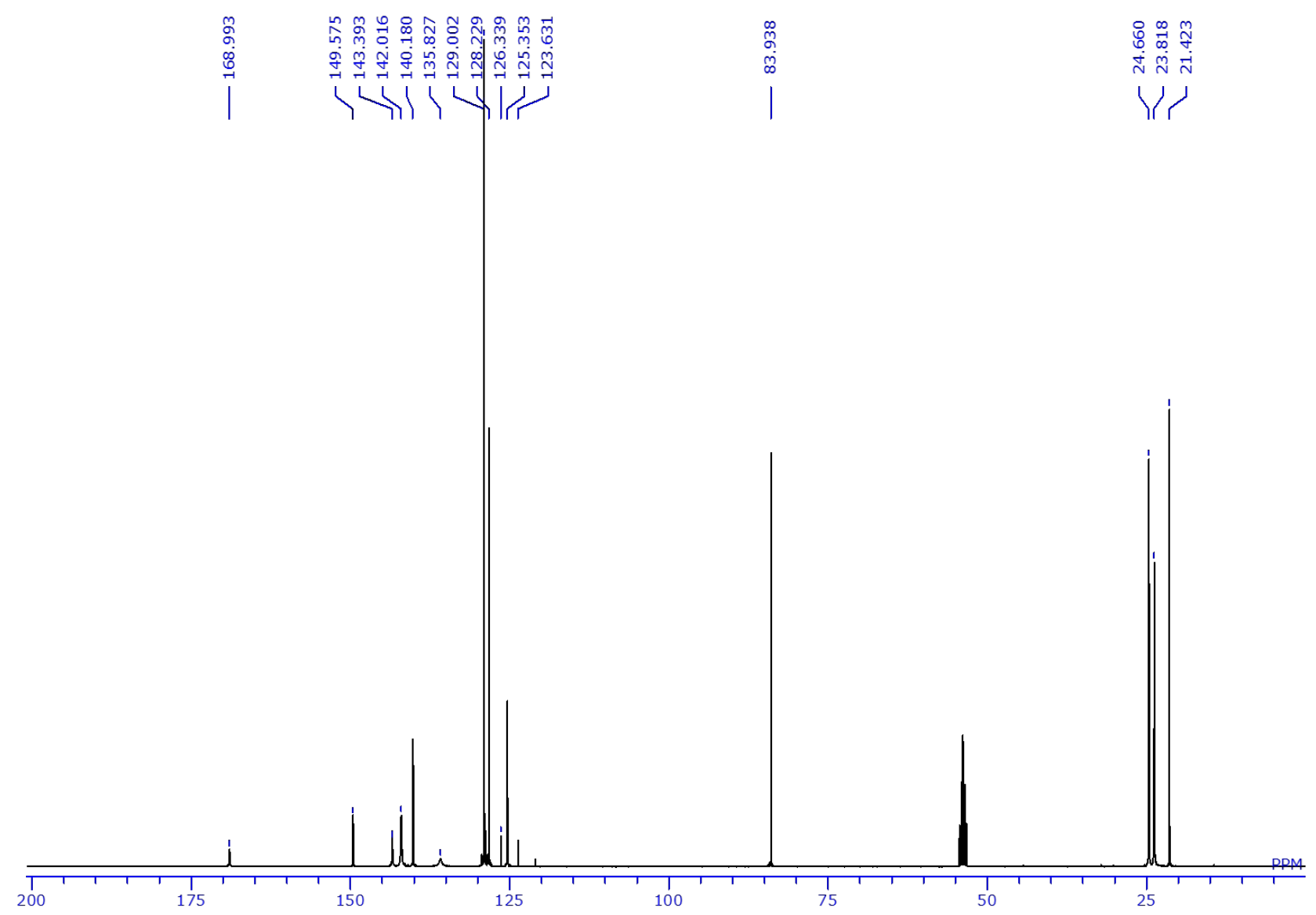

Figure S53. The ${ }^{13} \mathrm{C}$ NMR spectrum $\left(\mathrm{CD}_{2} \mathrm{Cl}_{2}\right)$ of $\mathbf{3 E a}$ 


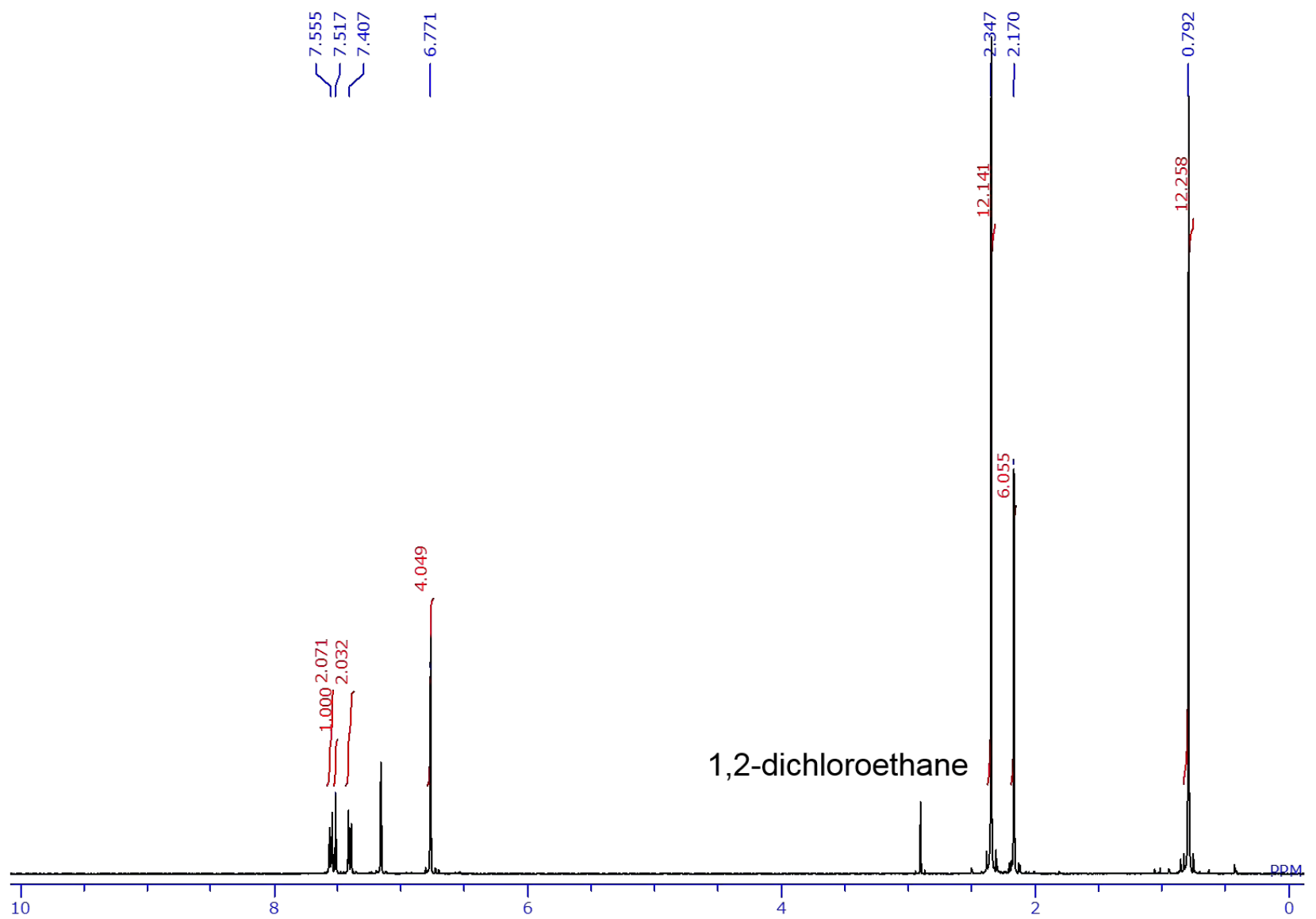

Figure S54. The ${ }^{1} \mathrm{H}$ NMR spectrum $\left(\mathrm{C}_{6} \mathrm{D}_{6}\right)$ of $\mathbf{3 E b}$

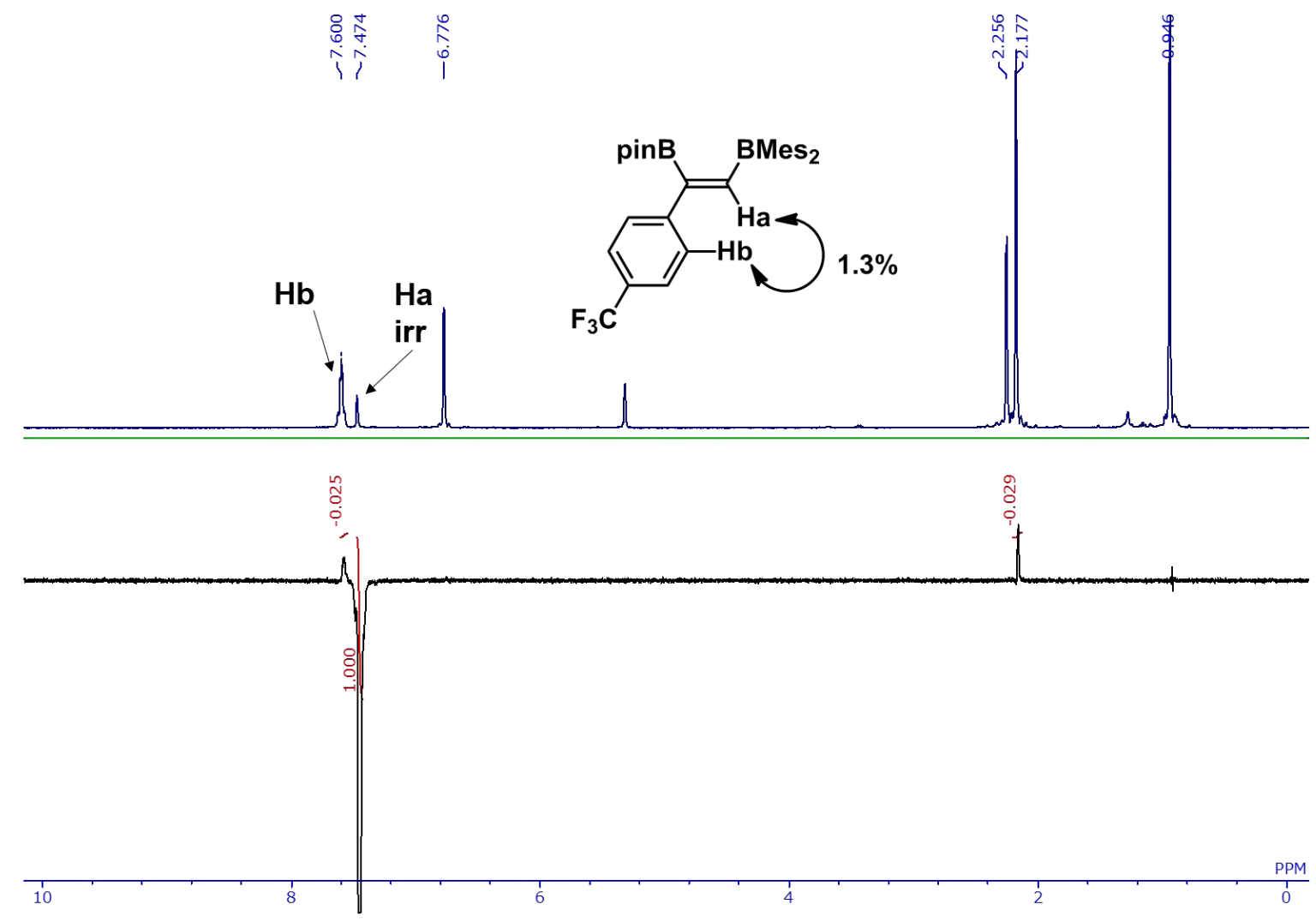

Figure S55. The differential ${ }^{1} \mathrm{H}$ NOE spectrum $\left(\mathrm{CD}_{2} \mathrm{Cl}_{2}\right)$ of $\mathbf{3 E b}$ with irradiation to the signal of vinylic $\mathrm{H}_{\mathrm{a}}$ 


\section{NMR yield of 3Ea and 3Eb in run 9, Table 2}

The procedure described in run 1, Table 1 was used. Reaction condition: Toluene $(500 \mu L), 1$ (75.3 mg, 0.200 mmol), 4-trifluoromethylphenylacetylene $(31.6 \mu \mathrm{L}, 0.220 \mathrm{mmol}), 100{ }^{\circ} \mathrm{C}, 59 \mathrm{~h}$, trimethoxybenzene $(14.5 \mathrm{mg}$, $0.0863 \mathrm{mmol})$, crude $(117.7 \mathrm{mg}$ ); NMR yield: 3Ea, 69\%; 3Eb, 16\%. See Figure S56 for NMR spectrum of the crude product.
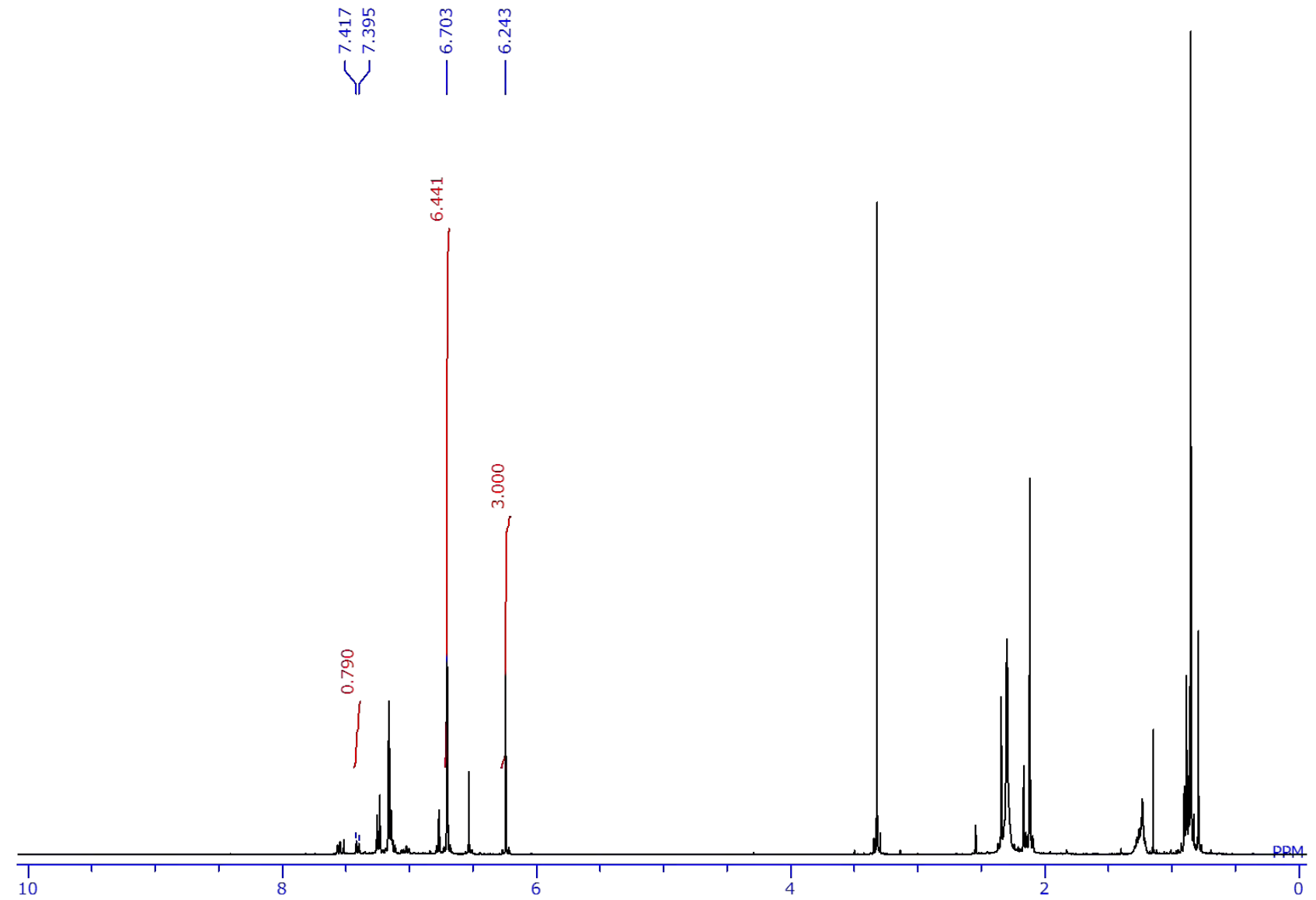

Figure S56. The ${ }^{1} \mathrm{H}$ NMR spectrum of the reaction mixture in run 9, Table 1 (6.70 ppm: 3Ea; 7.41 ppm: 3Eb; 6.23 ppm: internal standard, 1,3,5-trimethoxybenzene) 


\section{Base-catalyzed reaction of 1 with 4-trifluoromethylphenylacetylene (Table 2, run 10)}

In a glovebox, to a solution of 4-trifluoromethylphenylacetylene $(79.1 \mu \mathrm{L}, 0.550 \mathrm{mmol})$ in toluene $(1.25 \mathrm{~mL})$, ${ }^{n} \mathrm{BuLi}(0.100 \mathrm{M}$ diluted in toluene, $150 \mu \mathrm{L}, 15.0 \mu \mathrm{mol})$ was added dropwise at room temperature. After stirring the reaction mixture at room temperature for $3 \mathrm{~min}, 1(188.1 \mathrm{mg}, 0.500 \mathrm{mmol})$ and DME $(0.100 \mathrm{M}$ diluted in toluene, $150 \mu \mathrm{L}, 15.0 \mu \mathrm{mol})$ were added to the reaction mixture at room temperature. After the reaction mixture stirred at $100{ }^{\circ} \mathrm{C}$ for $8 \mathrm{~h}$, volatiles were removed from the pale yellow solution in vacuo. The residue was triturated with hexane and the resulting suspension was filtered through a pad of Celite. After volatiles were removed from the filtrate in vacuo, the residue was purified by recycling GPC (15 cycles) afforded yellow oil of 3Ec (117.4 mg, $0.215 \mathrm{mmol}, 43 \%$ ). Single crystals of 3Ec suitable for X-ray diffraction analysis were obtained by slow evaporation of its hexane/benzene $(1: 1, \mathrm{v} / \mathrm{v})$ solution to the coexistent silica-gel in a capped vial at room temperature. 3Ec: ${ }^{1} \mathrm{H}$ NMR $\left(400 \mathrm{MHz}, \mathrm{C}_{6} \mathrm{D}_{6}\right) \delta 1.06\left(\mathrm{~s}, 12 \mathrm{H}\right.$, pin- $\left.\mathrm{CH}_{3}\right), 2.07\left(\mathrm{~s}, 6 \mathrm{H}, p-\mathrm{CH}_{3}\right), 2.19\left(\mathrm{~s}, 12 \mathrm{H}, o-\mathrm{CH}_{3}\right)$, 6.55 (s, 4H, ArH of Mes), 7.10 (d, J=9 Hz, 2H, ArH), 7.25 (d, $J=9 \mathrm{~Hz}, 2 \mathrm{H}, \mathrm{ArH}), 8.15(\mathrm{~s}, 1 \mathrm{H}, \mathrm{CH}) ;{ }^{11} \mathrm{~B} \mathrm{NMR}$

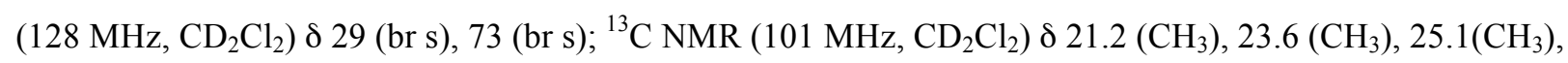
$84.7\left(4^{\circ}\right), 123.9\left(\mathrm{q}, \mathrm{CF}_{3}\right), 127.3(\mathrm{CH}), 128.3(\mathrm{CH}), 128.7(\mathrm{CH}), 138.1\left(4^{\circ}\right), 139.5\left(4^{\circ}\right), 140.4\left(4^{\circ}\right), 1^{4} 2.7\left(4^{\circ}\right.$, bonding to the B nucleus), $146.7\left(4^{\circ}\right), 150.3$ (br, $4^{\circ}$, bonding to the $\mathrm{B}$ nucleus), 157.8 (br, $\mathrm{CH}$, bonding to the $\mathrm{B}$ nucleus); mp 106-108 ${ }^{\circ} \mathrm{C}$ (decomp.); HRMS (ESI+) Calcd for $\mathrm{C}_{33} \mathrm{H}_{39} \mathrm{~B}_{2} \mathrm{~F}_{3} \mathrm{O}_{2}$ : 546.3089, found: 546.3099.

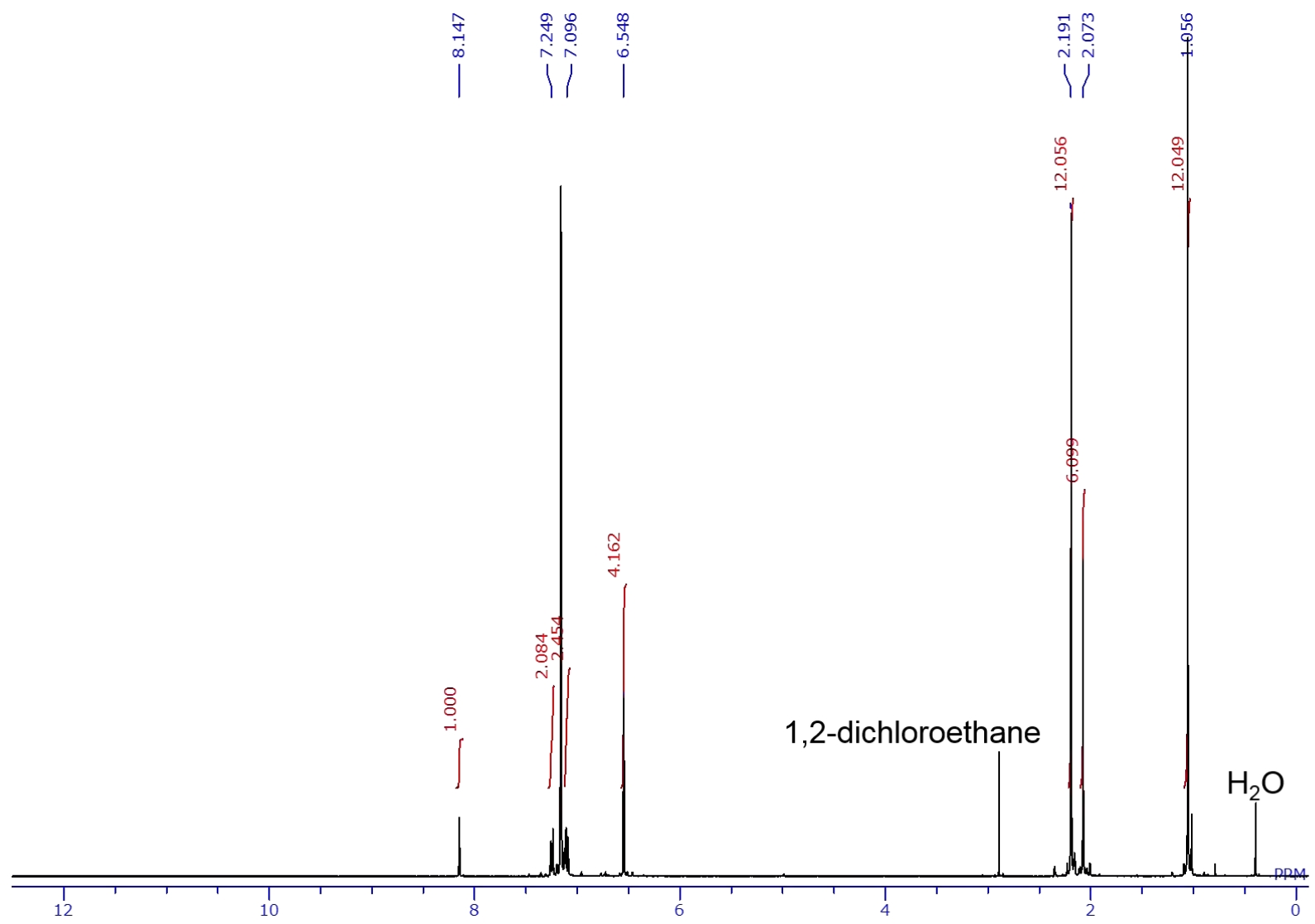

Figure S57. The ${ }^{1} \mathrm{H}$ NMR spectrum $\left(\mathrm{C}_{6} \mathrm{D}_{6}\right)$ of $\mathbf{3 E c}$ 


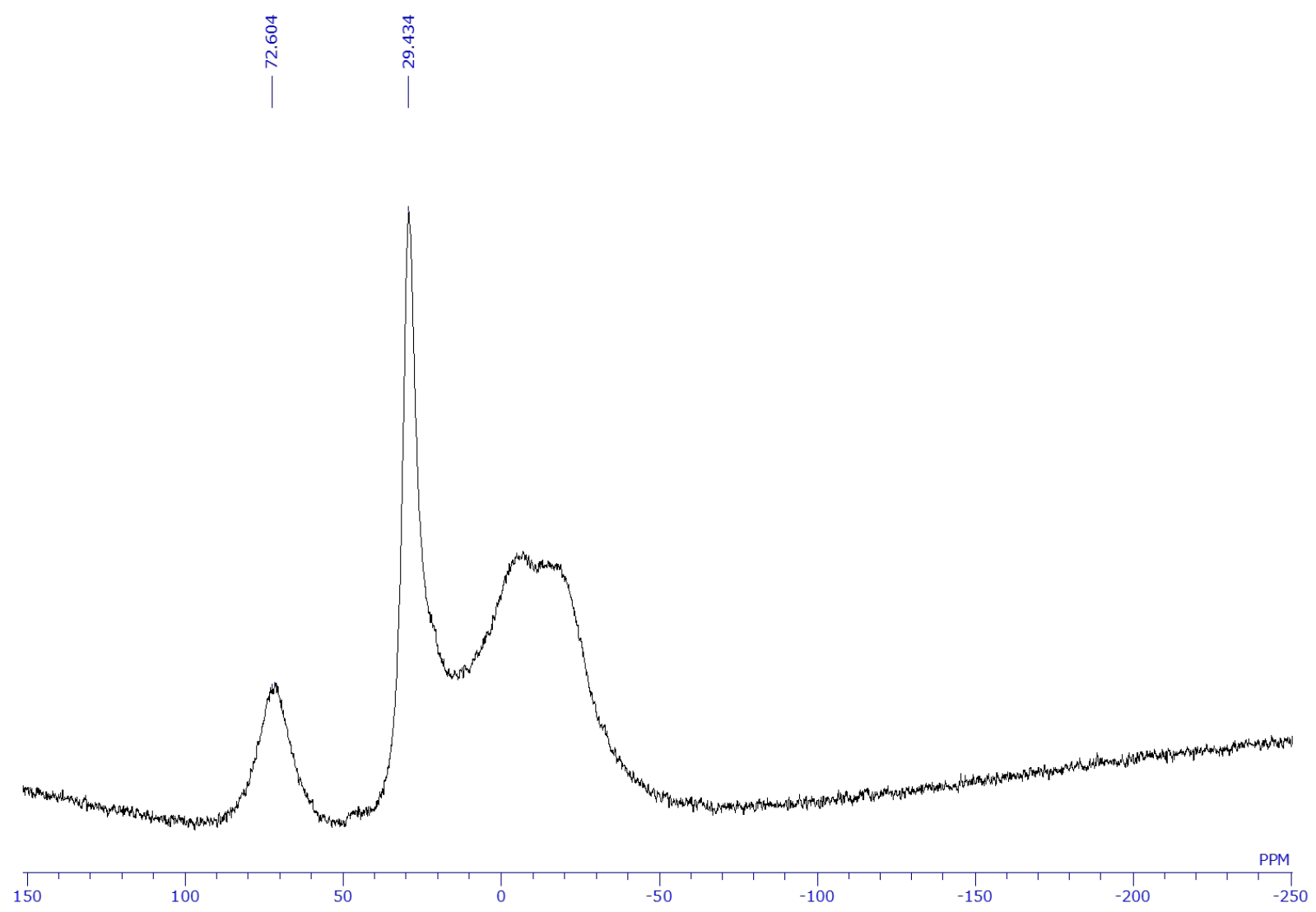

Figure S58. The ${ }^{11} \mathrm{~B}$ NMR spectrum (borosilicate NMR tube, $\mathrm{CD}_{2} \mathrm{Cl}_{2}$ ) of $\mathbf{3 E c}$
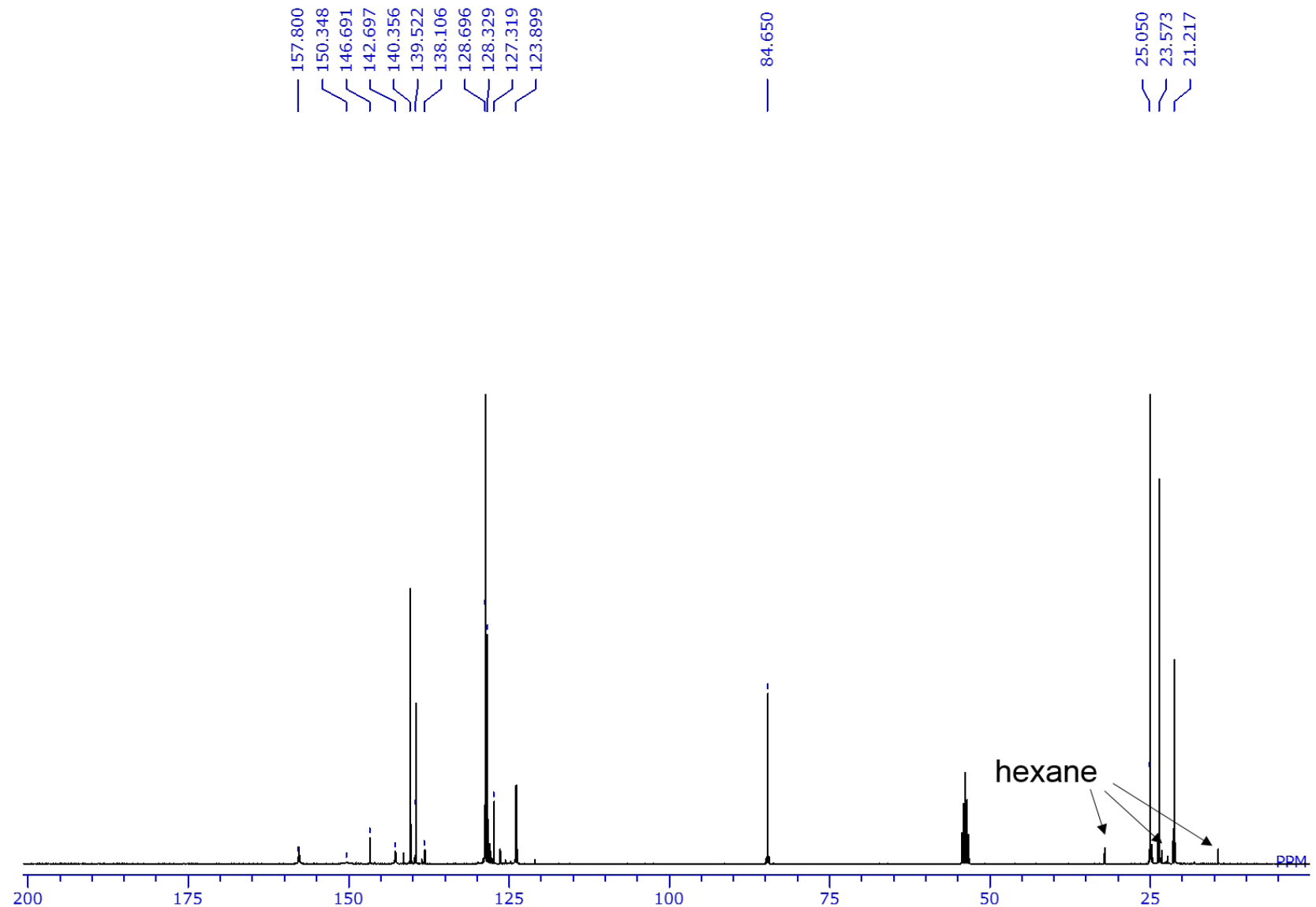

Figure S59. The ${ }^{13} \mathrm{C}$ NMR spectrum $\left(\mathrm{CD}_{2} \mathrm{Cl}_{2}\right)$ of $\mathbf{3 E c}$ 
NMR yield of 3Ea, 3Eb and 3Ec, in run 10, Table 2

The procedure described in run 9, Table 1 was used. Reaction condition: Toluene (500 $\mu \mathrm{L}), 1$ (75.2 mg, 0.200 mmol), 4-trifluoromethylphenylacetylene $(31.6 \mu \mathrm{L}, 0.220 \mathrm{mmol}),{ }^{n} \mathrm{BuLi}(0.100 \mathrm{M}$ diluted in toluene, $60.0 \mu \mathrm{L}$, $6.00 \mu \mathrm{mol})$, DME $(0.100 \mathrm{M}$ diluted in toluene, $60.0 \mu \mathrm{L}, 6.00 \mu \mathrm{mol}), 100{ }^{\circ} \mathrm{C}, 8 \mathrm{~h}$, trimethoxybenzene $(10.8 \mathrm{mg}$, $0.0643 \mathrm{mmol}$ ), crude (118.9 mg); NMR yield: 3Ea, 18\%; 3Eb, 6\%; 3Ec, 59\%. See Figure S60 for NMR spectrum of the crude product.
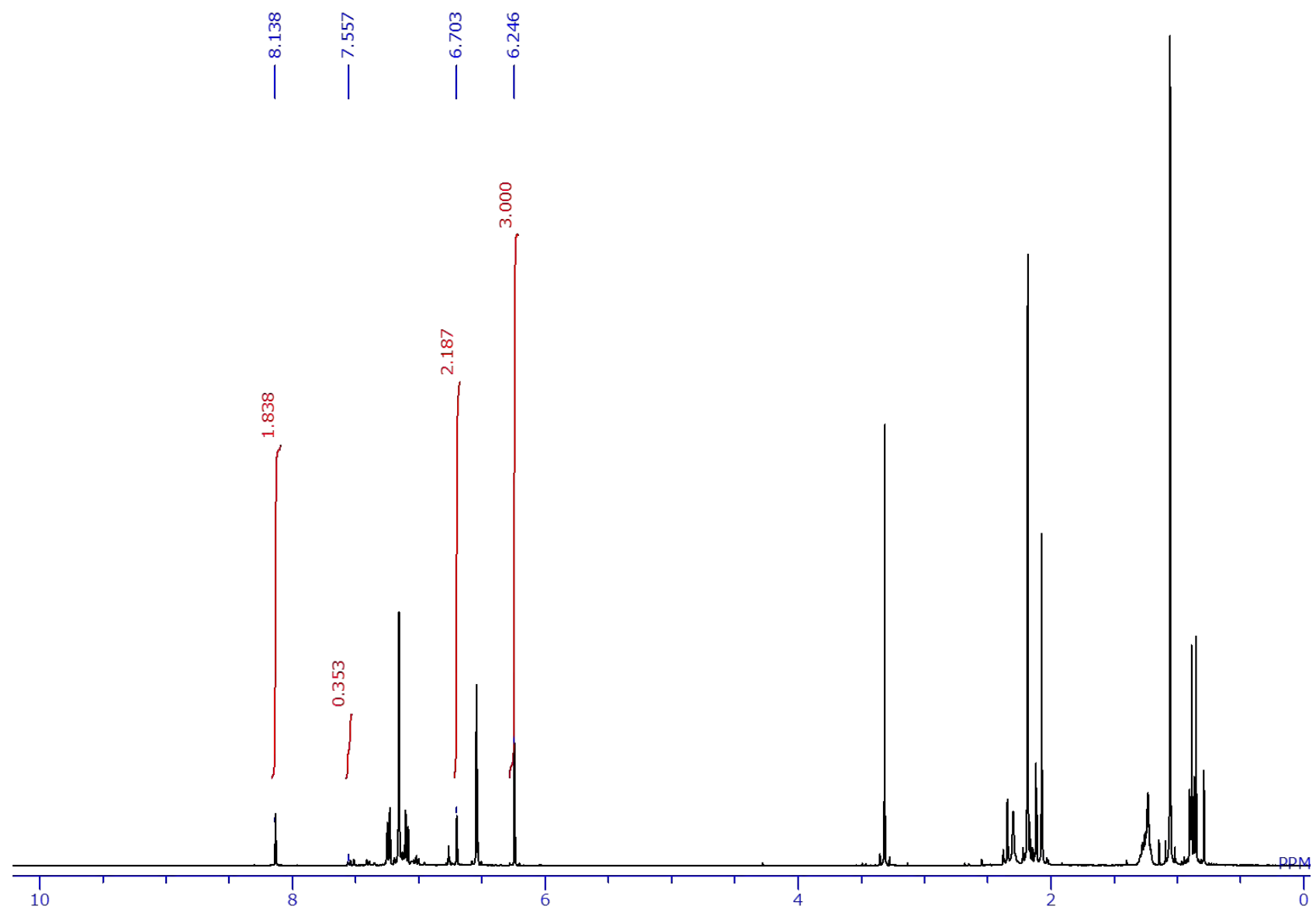

Figure S60. The ${ }^{1} \mathrm{H}$ NMR spectrum of the reaction mixture in run 10, Table 2 (6.70 ppm: 3Ea; 7.557 ppm: 3Eb; 8.14 ppm: 3Ec; 6.25 ppm: internal standard, 1,3,5-trimethoxybenzene) 


\section{Direct reaction of 1 with 4-methoxycarbonylphenylacetylene (Table 2, run 11)}

In a glovebox, to a toluene solution $(1.25 \mathrm{~mL})$ of $\mathbf{1}(188 \mathrm{mg}, 0.500 \mathrm{mmol})$ in a $10 \mathrm{~mL} \mathrm{~J}$-young tube, 4-methoxycarbonylphenylacetylene $(88.3 \mathrm{mg}, 0.550 \mathrm{mmol})$ was added. After stirring the reaction mixture at $100{ }^{\circ} \mathrm{C}$ for $28 \mathrm{~h}$, volatiles were removed from the clear solution in vacuo. Purification of the residue by GPC (30 cycles) afforded pale yellow oils of 3Fa (96.9 mg, $0.181 \mathrm{mmol}, 36 \%)$ and 3Fb (3.5 mg, 6.52 $\mu \mathrm{mol}, 1 \%)$. Single crystals of 3Fa suitable for X-ray diffraction analysis were obtained by recrystallization from its hexane solution. 3Fa: ${ }^{1} \mathrm{H}$ NMR $\left(400 \mathrm{MHz}, \mathrm{C}_{6} \mathrm{D}_{6}\right) \delta 0.86\left(\mathrm{~s}, 12 \mathrm{H}, \mathrm{pin}-\mathrm{CH}_{3}\right), 2.11\left(\mathrm{~s}, 6 \mathrm{H}, p-\mathrm{CH}_{3}\right), 2.33\left(\mathrm{~s}, 12 \mathrm{H}, o-\mathrm{CH}_{3}\right), 3.41(\mathrm{~s}, 3 \mathrm{H}$, $\left.\mathrm{CH}_{3} \mathrm{O}\right), 6.62(\mathrm{~s}, 1 \mathrm{H}, \mathrm{CH}), 6.70\left(\mathrm{~s}, 4 \mathrm{H}, \mathrm{ArH}\right.$ of Mes), $7.33(\mathrm{~d}, J=9 \mathrm{~Hz}, 2 \mathrm{H}, \mathrm{ArH}), 7.93(\mathrm{~d}, J=9 \mathrm{~Hz}, 2 \mathrm{H}, \mathrm{ArH}) ;{ }^{11} \mathrm{~B}$ NMR (128 MHz, $\left.\mathrm{CD}_{2} \mathrm{Cl}_{2}\right) \delta 30$ (br s), 76 (br s); ${ }^{13} \mathrm{C} \mathrm{NMR}\left(101 \mathrm{MHz}, \mathrm{CD}_{2} \mathrm{Cl}_{2}\right) \delta 21.4\left(\mathrm{CH}_{3}\right), 23.7\left(\mathrm{CH}_{3}\right), 24.6$ $\left(\mathrm{CH}_{3}\right), 52.2\left(\mathrm{CH}_{3}\right), 83.9\left(4^{\circ}\right), 127.9(\mathrm{CH}), 128.9(\mathrm{CH}), 128.9\left(4^{\circ}\right), 129.6\left(4^{\circ}\right), 135.6(\mathrm{br}, \mathrm{CH}$, bonding to the B nucleus), $140.0\left(4^{\circ}\right), 141.9\left(\mathrm{br}, 4^{\circ}\right.$, bonding to the B nucleus), $143.4\left(4^{\circ}\right), 150.4\left(4^{\circ}\right), 169.0\left(4^{\circ}\right.$, bonding to the $\mathrm{B}$ nucleus); mp 168-169 ${ }^{\circ} \mathrm{C}$; HRMS (ESI+) Calcd for $\mathrm{C}_{34} \mathrm{H}_{42} \mathrm{~B}_{2} \mathrm{O}_{4}$ : 536.3248, found: 536.3259; 3Fb: ${ }^{1} \mathrm{H}$ NMR (400 $\left.\mathrm{MHz}, \mathrm{C}_{6} \mathrm{D}_{6}\right) \delta 0.78\left(\mathrm{~s}, 12 \mathrm{H}, \mathrm{pin}-\mathrm{CH}_{3}\right), 2.16\left(\mathrm{~s}, 6 \mathrm{H}, p-\mathrm{CH}_{3}\right), 2.35\left(\mathrm{~s}, 12 \mathrm{H}, o-\mathrm{CH}_{3}\right), 3.49\left(\mathrm{~s}, 3 \mathrm{H}, \mathrm{CH}_{3} \mathrm{O}\right) 6.76(\mathrm{~s}, 4 \mathrm{H}$, ArH of Mes), 7.60 (s, 1H, CH), 7.72 (d, $J=9 \mathrm{~Hz}, 2 \mathrm{H}, \mathrm{ArH}), 8.21$ (d, $J=9,2 \mathrm{H}, \mathrm{ArH})$; HRMS (ESI+) Calcd for $\mathrm{C}_{34} \mathrm{H}_{42} \mathrm{~B}_{2} \mathrm{O}_{4}: 536.3270$, found: 536.3267 .

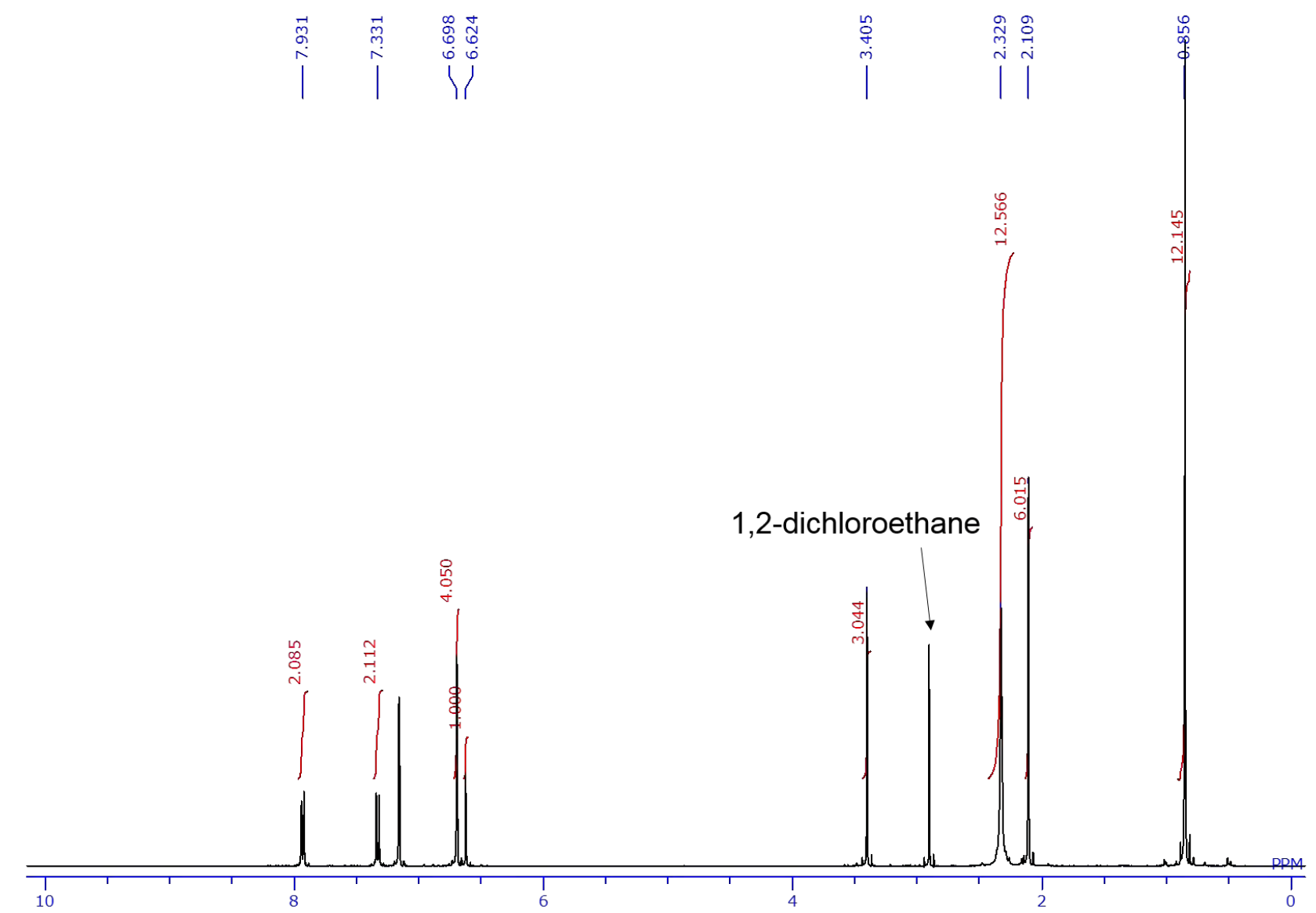

Figure S61. The ${ }^{1} \mathrm{H}$ NMR spectrum $\left(\mathrm{C}_{6} \mathrm{D}_{6}\right)$ of $\mathbf{3 F a}$ 


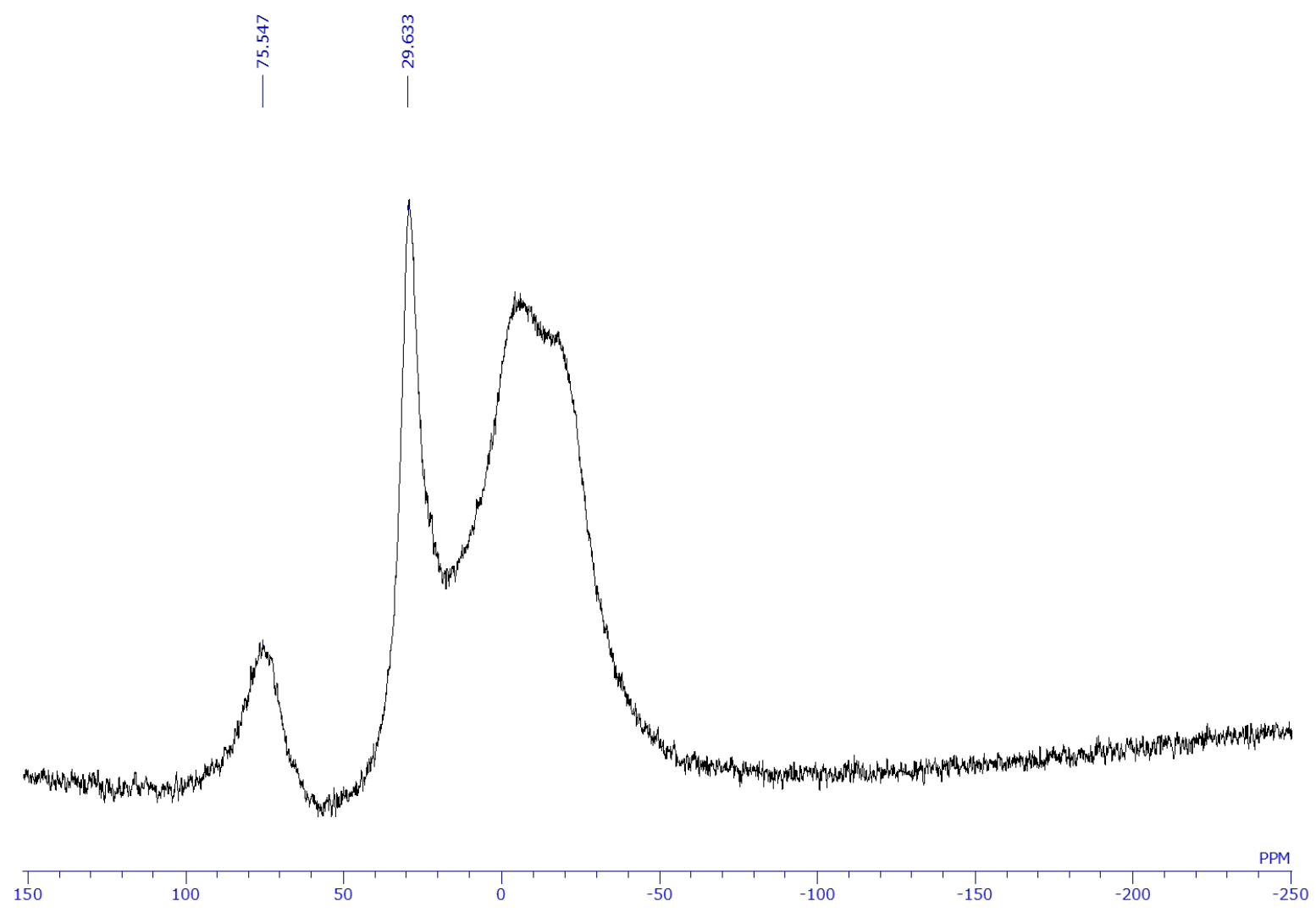

Figure S62. The ${ }^{11} \mathrm{~B}$ NMR spectrum (borosilicate NMR tube, $\mathrm{CD}_{2} \mathrm{Cl}_{2}$ ) of $\mathbf{3 F a}$

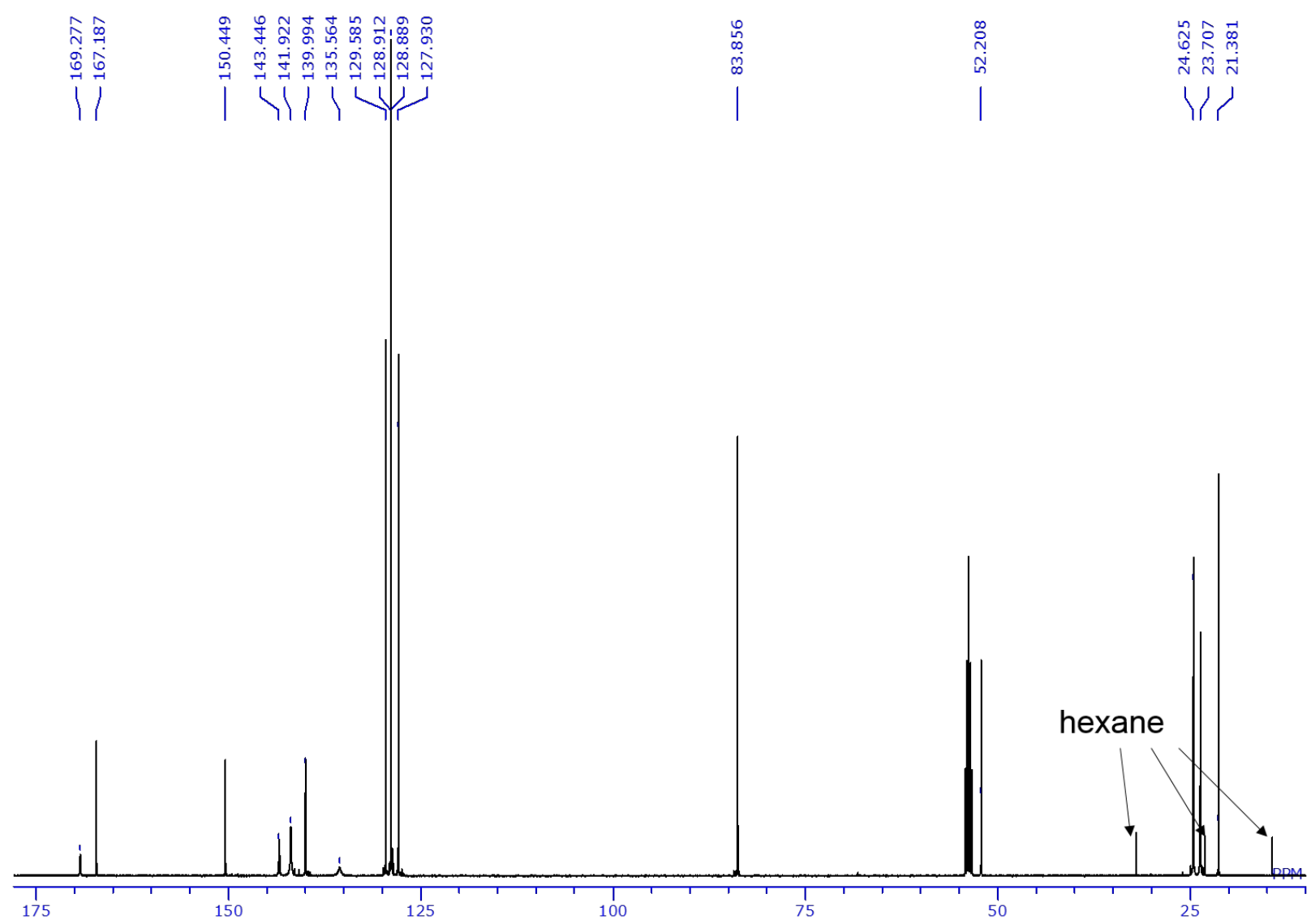

Figure S63. The ${ }^{13} \mathrm{C}$ NMR spectrum $\left(\mathrm{CD}_{2} \mathrm{Cl}_{2}\right)$ of $\mathbf{3 F a}$ 


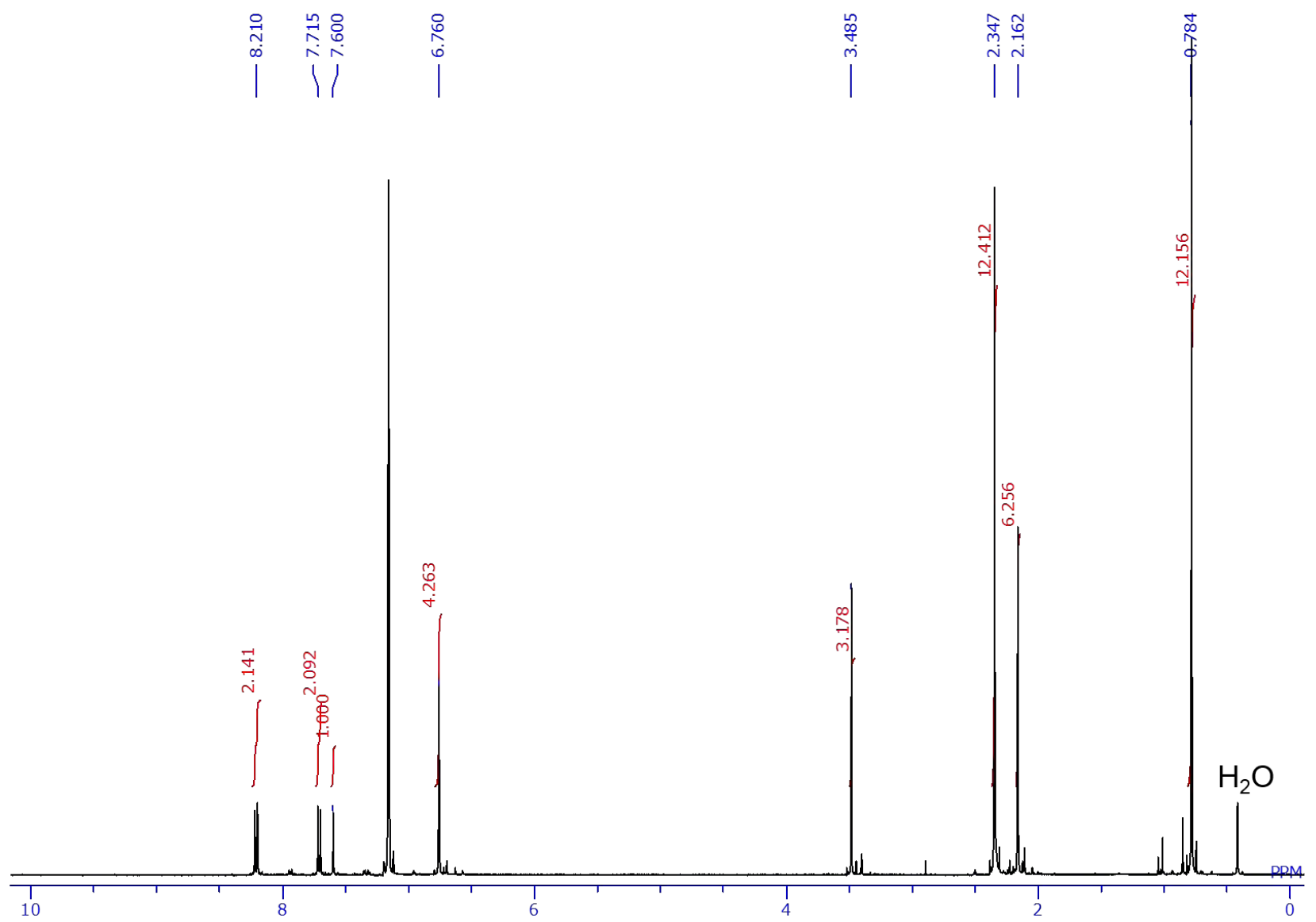

Figure S64. The ${ }^{1} \mathrm{H}$ NMR spectrum $\left(\mathrm{C}_{6} \mathrm{D}_{6}\right)$ of $\mathbf{3 F b}$

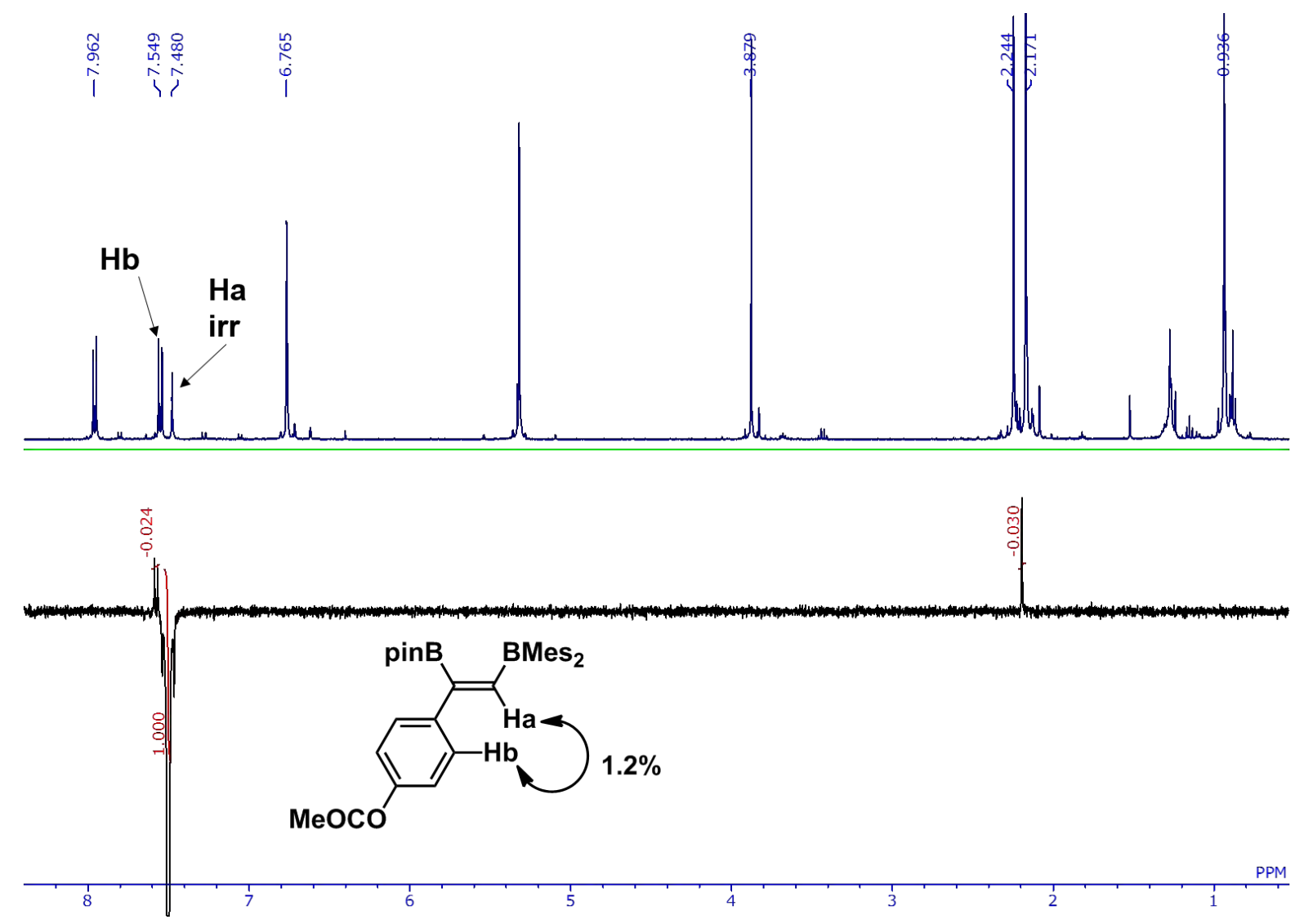

Figure S65. The differential ${ }^{1} \mathrm{H}$ NOE spectrum $\left(\mathrm{C}_{6} \mathrm{D}_{6}\right)$ of $\mathbf{3 F b}$ with irradiation to the signal of vinylic $\mathrm{H}_{\mathrm{a}}$ 
NMR yield of $3 F$ and $3 F b$ in run 11 , Table 2

The procedure described in run 1, Table 1 was used. Reaction condition: Toluene (500 $\mu \mathrm{L}), 1$ (75.4 mg, 0.201 mmol), 4-methoxycarbonylphenylacetylene $(35.0 \mathrm{mg}, 0.220 \mathrm{mmol}), 100{ }^{\circ} \mathrm{C}, 28 \mathrm{~h}$, trimethoxybenzene $(10.4 \mathrm{mg}$, $0.0619 \mathrm{mmol}$ ), crude (124.6 mg); NMR yield: 3Fa, 64\%; 3Fb, 17\%. See Figure S66 for the ${ }^{1} \mathrm{H}$ NMR spectrum of the crude product.
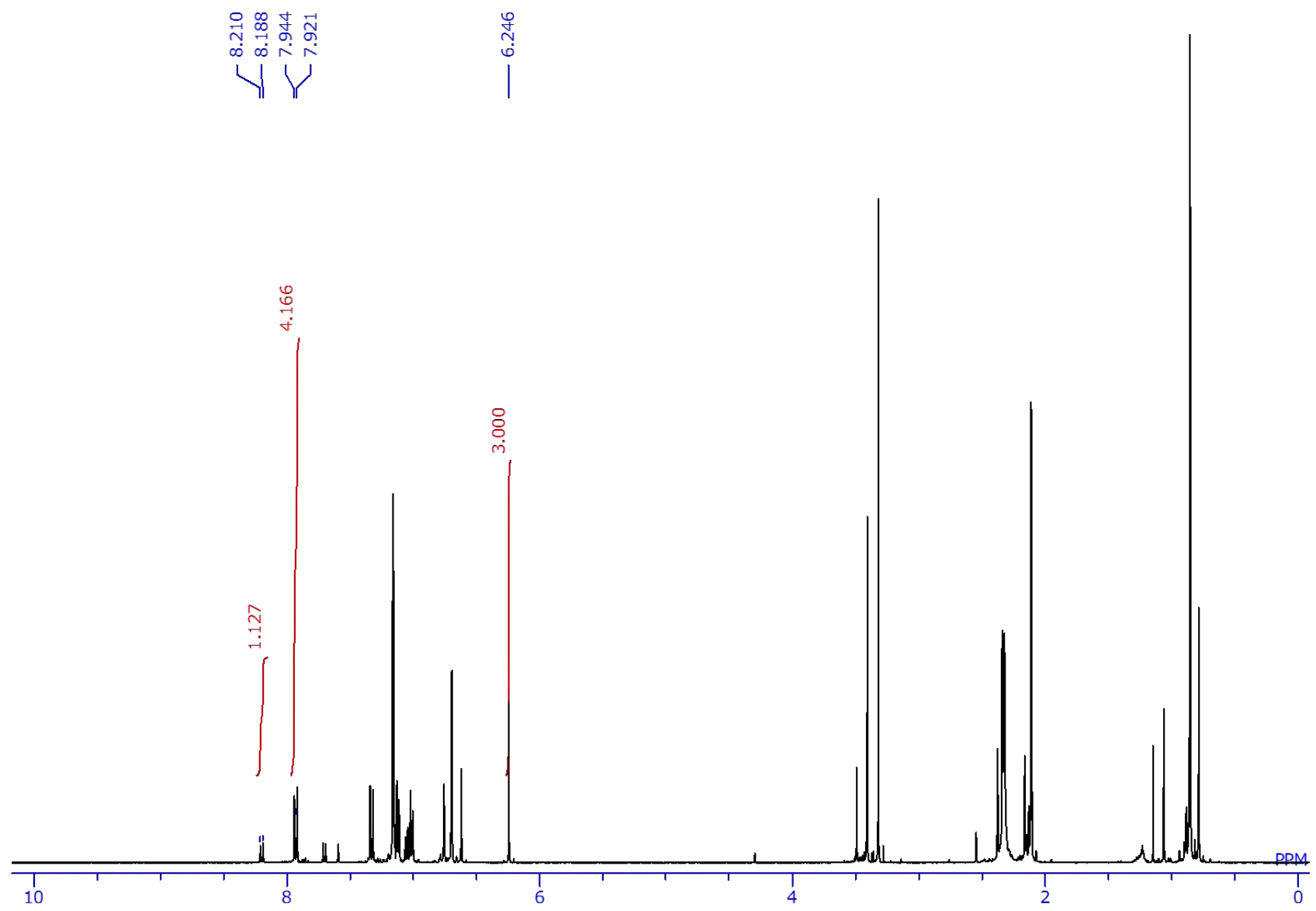

Figure S66. The ${ }^{1} \mathrm{H}$ NMR spectrum of the reaction mixture in run 11, Table 2 (7.93 ppm: 3Fa; 8.20 ppm: 3Fb; 6.23 ppm: internal standard, 1,3,5-trimethoxybenzene) 
Base-catalyzed reaction of 1 with 4-methoxycarbonylphenylacetylene (Table 2, run 12)

Because 3Fc was not isolated, the following NMR experiment was examined to afford a tentative assignment of 3Fc.

NMR yield of $3 \mathrm{Fa}, 3 \mathrm{Fb}$ and $3 \mathrm{Fc}$, in run 12 , Table 2

The procedure described in run 9, Table 1 was used. Reaction condition: Toluene (500 $\mu \mathrm{L}), 1$ (75.2 mg, 0.200 mmol), 4-methoxycarbonylphenylacetylene $(35.2 \mathrm{mg}, 0.220 \mathrm{mmol}){ }^{n} \mathrm{BuLi}(0.100 \mathrm{M}$ diluted in toluene, $60.0 \mu \mathrm{L}$, $6.00 \mu \mathrm{mol}), \operatorname{DME}(0.100 \mathrm{M}$ diluted in toluene, $60.0 \mu \mathrm{L}, 6.00 \mu \mathrm{mol}), 100{ }^{\circ} \mathrm{C}, 42 \mathrm{~h}$, trimethoxybenzene $(11.0 \mathrm{mg}$, $65.5 \mu \mathrm{mol}$ ), crude (122.3 mg); NMR yield: 3Fa, 38\%; 3Fb, 10\%; 3Fc, 26\%. See Figures $\mathrm{S} 67$ and $\mathrm{S} 68$ for the ${ }^{1} \mathrm{H}$ NMR spectrum of the crude product. In this reaction, 3Fc could not be completely isolated but was tentatively assigned as follows. ${ }^{1} \mathrm{H}$ NMR $\left(400 \mathrm{MHz}, \mathrm{C}_{6} \mathrm{D}_{6}\right) \delta 1.05\left(\mathrm{~s}, 12 \mathrm{H}\right.$, pin- $\left.\mathrm{CH}_{3}\right), 2.05\left(\mathrm{~s}, 6 \mathrm{H}, p-\mathrm{CH}_{3}\right), 2.22(\mathrm{~s}, 12 \mathrm{H}$, $\left.o-\mathrm{CH}_{3}\right), 3.41\left(\mathrm{~s}, 3 \mathrm{H}, \mathrm{CH}_{3} \mathrm{O}\right) 6.57(\mathrm{~s}, 4 \mathrm{H}, \mathrm{ArH}$ of Mes), 7.41 (d, $J=9 \mathrm{~Hz}, 2 \mathrm{H}, \mathrm{ArH}), 8.91(\mathrm{~d}, J=9,2 \mathrm{H}, \mathrm{ArH}), 8.16$ (s, $1 \mathrm{H}, \mathrm{CH})$.

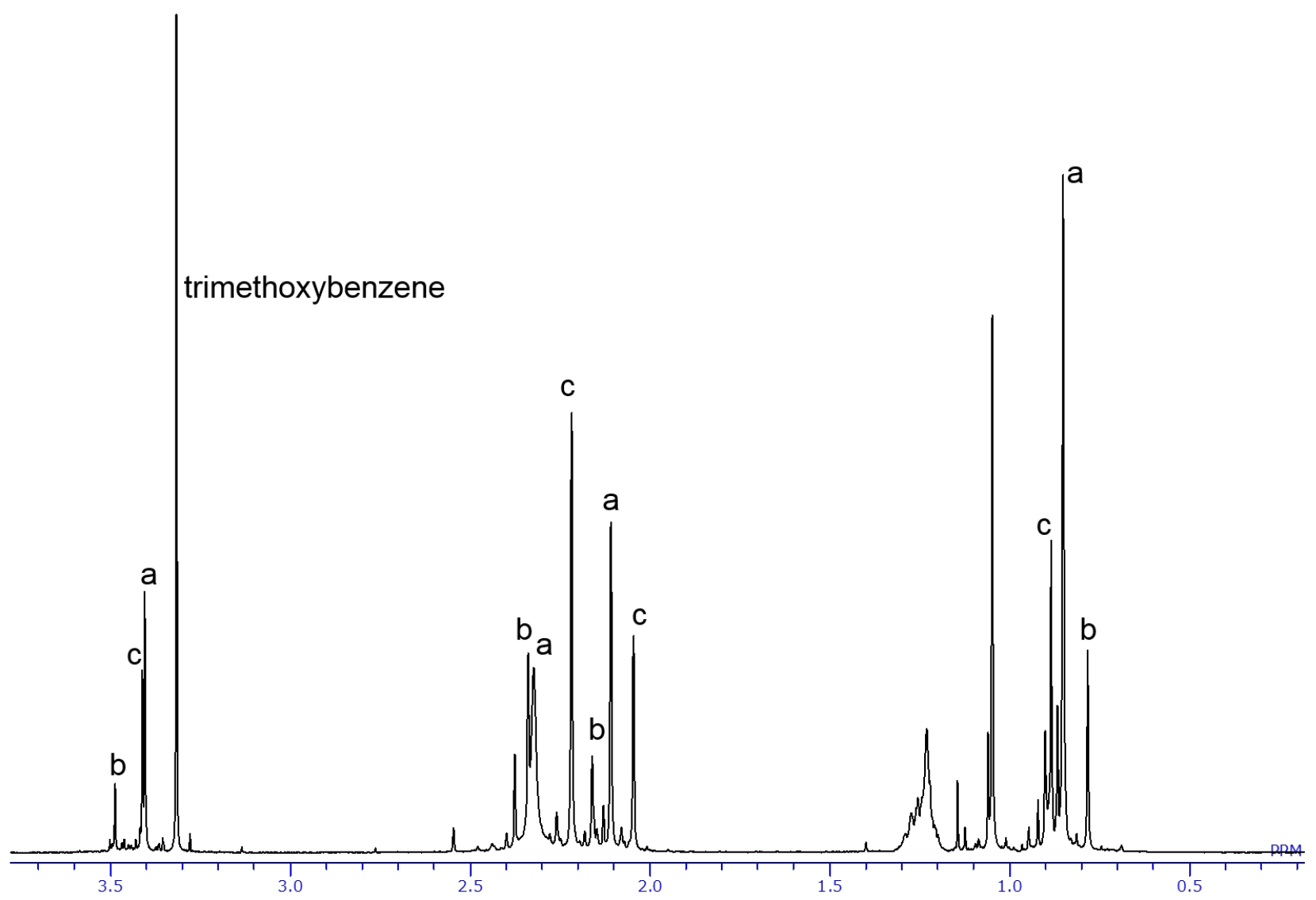

Figure S67. The high-field region of the ${ }^{1} \mathrm{H}$ NMR spectrum $\left(\mathrm{C}_{6} \mathrm{D}_{6}\right)$ for the reaction mixture of run 12 


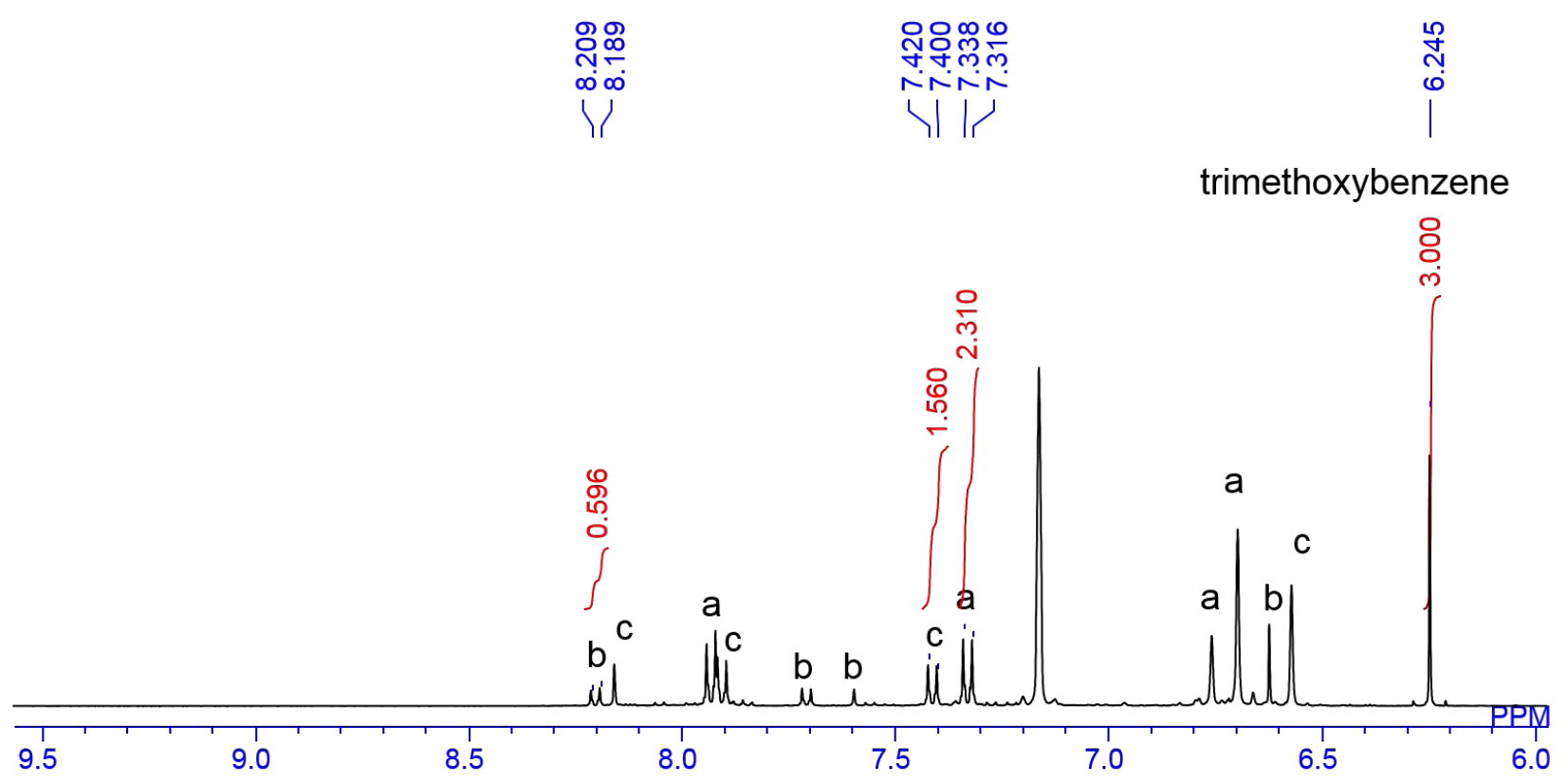

Figure S68. The low-field region of the ${ }^{1} \mathrm{H}$ NMR spectrum $\left(\mathrm{C}_{6} \mathrm{D}_{6}\right)$ for the reaction mixture of run 12 (7.32 ppm: 3Fa; 8.20 ppm: 3Fb; 7.41 ppm: 3Fc; 6.24 ppm: internal standard, 1,3,5-trimethoxybenzene) 


\section{Direct reaction of 1 with 1-octyne (Table 2, run 13)}

In a glovebox, to a toluene solution $(1.50 \mathrm{~mL})$ of $1(226 \mathrm{mg}, 0.600 \mathrm{mmol})$ in a $10 \mathrm{~mL}$ J-young tube, 1-octyne $(97.0 \mu \mathrm{L}, 0.660 \mathrm{mmol})$ was added. After stirring the reaction mixture at $100{ }^{\circ} \mathrm{C}$ for $4 \mathrm{~h}$, volatiles were removed from the reaction mixture in vacuo. Purification of the residue by recycling GPC (26 cycles) afforded clear oil of 3Ga (91.0 mg, $0.187 \mathrm{mmol}, 37 \%)$ and 3Gb $(71.0 \mathrm{mg}, 0.146 \mathrm{mmol}, 29 \%)$. 3Ga: ${ }^{1} \mathrm{H}$ NMR $\left(400 \mathrm{MHz}, \mathrm{C}_{6} \mathrm{D}_{6}\right) \delta 0.80$ (t, $\left.J=7 \mathrm{~Hz}, 3 \mathrm{H}, \mathrm{CH}_{3}\right), 0.85\left(\mathrm{~s}, 12 \mathrm{H}\right.$, pin- $\left.\mathrm{CH}_{3}\right), 1.13\left(\mathrm{~m}, 6 \mathrm{H},\left(\mathrm{CH}_{2}\right)_{3}\right), 1.53\left(\mathrm{~m}, 2 \mathrm{H}, \mathrm{CH}_{2}\right), 2.15\left(\mathrm{~s}, 6 \mathrm{H}, p-\mathrm{CH}_{3}\right), 2.40$, (t, J $=9 \mathrm{~Hz}, 2 \mathrm{H}, \mathrm{CH}_{2}$ ), 2.40 (brs, $\left.12 \mathrm{H}, o-\mathrm{CH}_{3}\right), 6.33$ (s, $\left.1 \mathrm{H}, \mathrm{CH}\right), 6.75$ (s, 4H, ArH of Mes); ${ }^{11} \mathrm{~B}$ NMR (129 MHz, $\left.\mathrm{C}_{6} \mathrm{D}_{6}\right) \delta 29$ (br s), 77 (br s); ${ }^{13} \mathrm{C}$ NMR (126 MHz, $\left.\mathrm{C}_{6} \mathrm{D}_{6}\right) \delta 14.3\left(\mathrm{CH}_{3}\right), 21.6\left(\mathrm{CH}_{3}\right), 22.8\left(\mathrm{CH}_{2}\right), 22.9\left(\mathrm{CH}_{2}\right), 23.5$ (br, $\left.4^{\circ}\right), 24.5\left(\mathrm{CH}_{3}\right), 28.9\left(\mathrm{CH}_{2}\right), 29.8\left(\mathrm{CH}_{2}\right), 30.1\left(\mathrm{CH}_{2}\right), 38.8\left(\mathrm{CH}_{2}\right), 83.0\left(4^{\circ}\right), 128.3(\mathrm{br}, \mathrm{CH}$, bonding to the B nucleus), $128.8(\mathrm{CH}), 138.8$ ( $4^{\circ}$, bonding to the $\mathrm{B}$ nucleus), 143.2 (br, $4^{\circ}$, bonding to the $\mathrm{B}$ nucleus); HRMS (ESI+) Calcd for $\mathrm{C}_{32} \mathrm{H}_{48} \mathrm{~B}_{2} \mathrm{O}_{2}: 485.3762$, found: 485.3782; 3Gb: ${ }^{1} \mathrm{H}$ NMR (400 MHz, $\left.\mathrm{C}_{6} \mathrm{D}_{6}\right) \delta 0.83$ (s, 12H, pin- $\left.\mathrm{CH}_{3}\right), 0.91\left(\mathrm{t}, J=7 \mathrm{~Hz}, 3 \mathrm{H}, \mathrm{CH}_{3}\right), 1.31\left(\mathrm{~m}, 4 \mathrm{H},\left(\mathrm{CH}_{2}\right)_{2}\right), 1.38\left(\mathrm{~m}, 2 \mathrm{H}, \mathrm{CH}_{2}\right), 1.67\left(\mathrm{~m}, 2 \mathrm{H}, \mathrm{CH}_{2}\right), 2.17(\mathrm{~s}, 6 \mathrm{H}$, $\left.p-\mathrm{CH}_{3}\right), 2.40$ (s, 12H, o- $\mathrm{CH}_{3}$ ), 2.52 (t, $J=9 \mathrm{~Hz}, 2 \mathrm{H}, \mathrm{CH}_{2}$ ), 6.76 (s, 4H, ArH of Mes), 7.19 (s, 1H, CH); HRMS (ESI+) Calcd for $\mathrm{C}_{32} \mathrm{H}_{48} \mathrm{~B}_{2} \mathrm{O}_{2}: 485.3762$, found: 485.3774 .

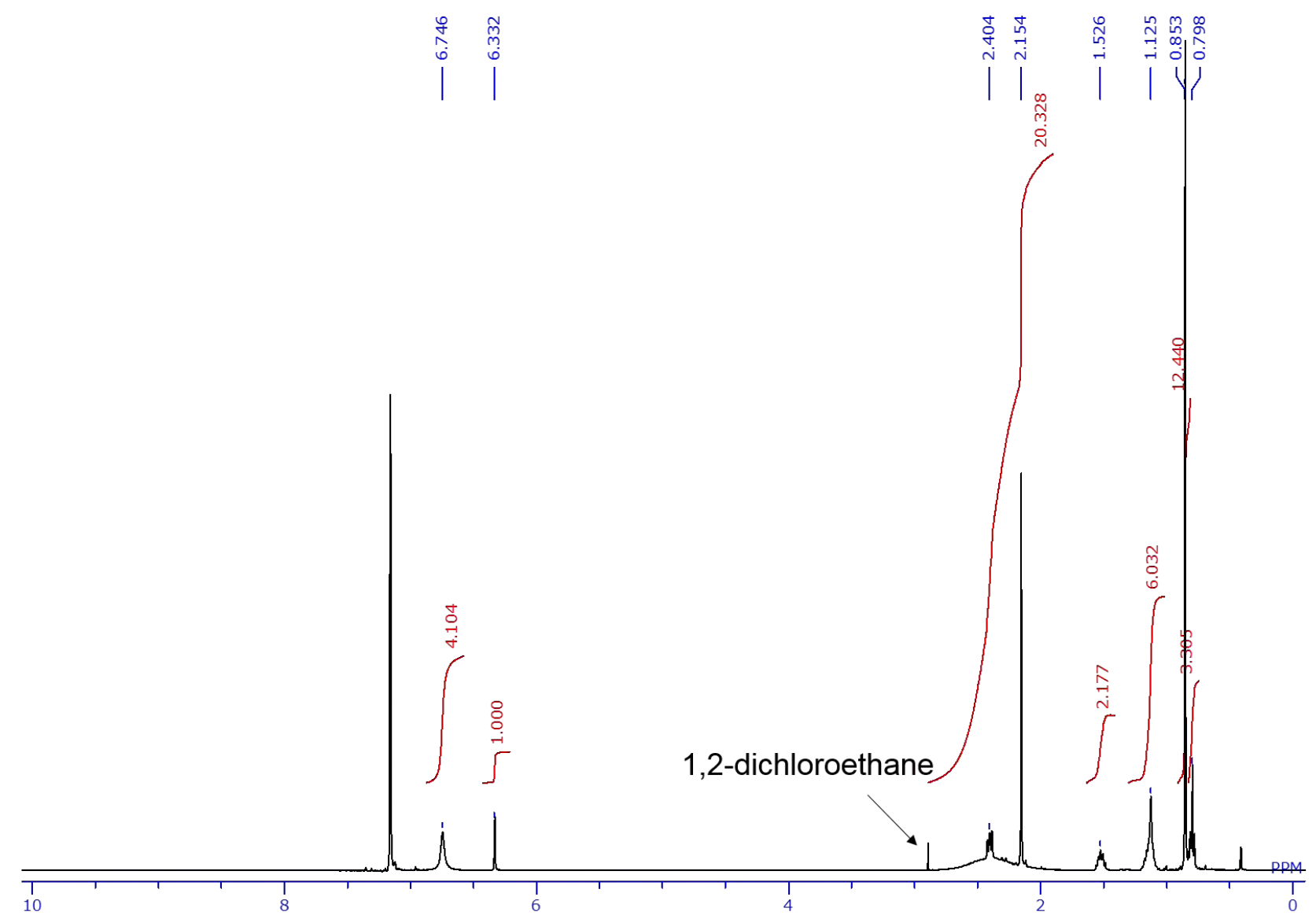

Figure S69. The ${ }^{1} \mathrm{H}$ NMR spectrum $\left(\mathrm{C}_{6} \mathrm{D}_{6}\right)$ of $\mathbf{3 G a}$ 


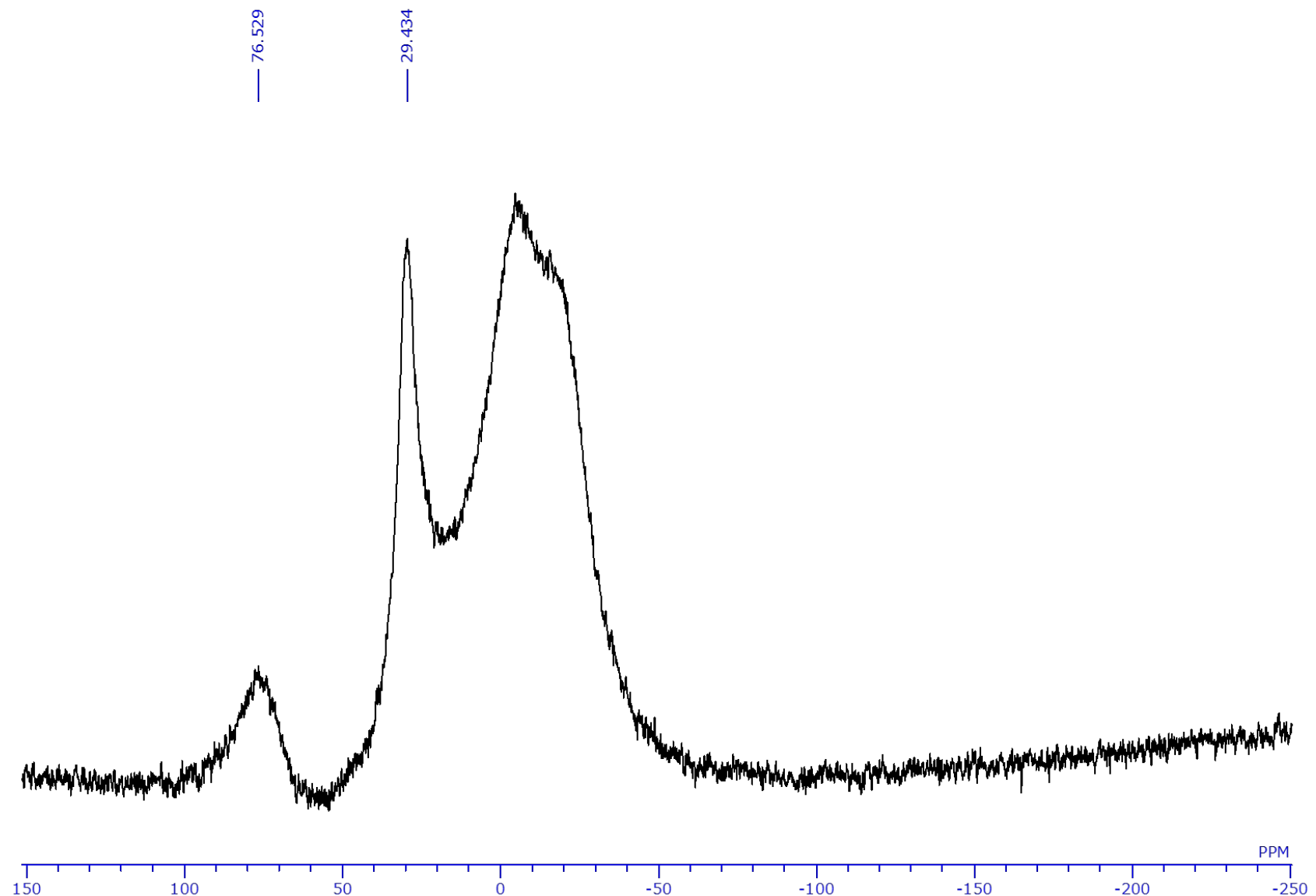

Figure S70. The ${ }^{11}$ B NMR spectrum (borosilicate NMR tube, $\mathrm{C}_{6} \mathrm{D}_{6}$ ) of $\mathbf{3 G a}$

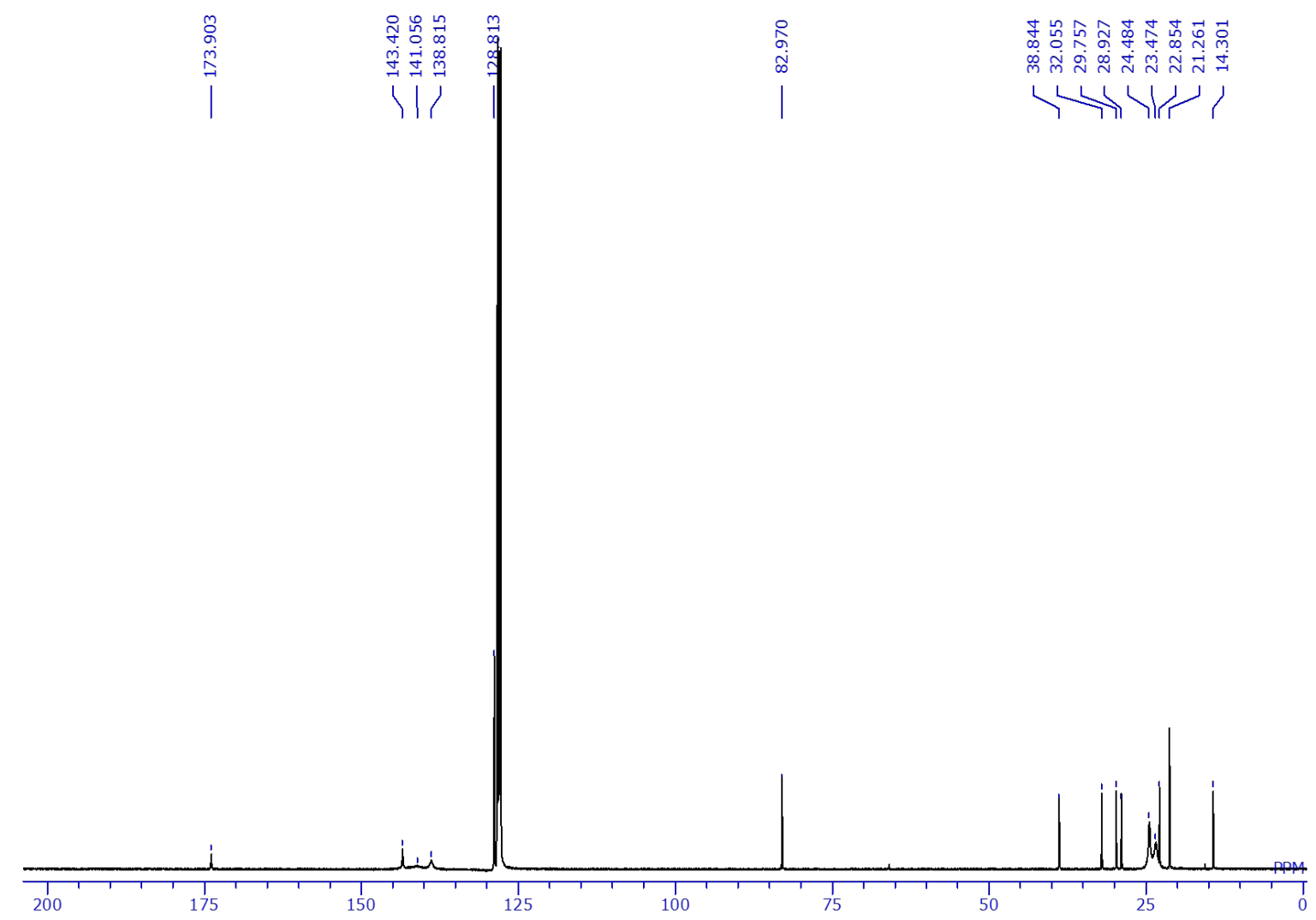

Figure S71. The ${ }^{13} \mathrm{C}$ NMR spectrum $\left(\mathrm{C}_{6} \mathrm{D}_{6}\right)$ of $\mathbf{3 G a}$ 


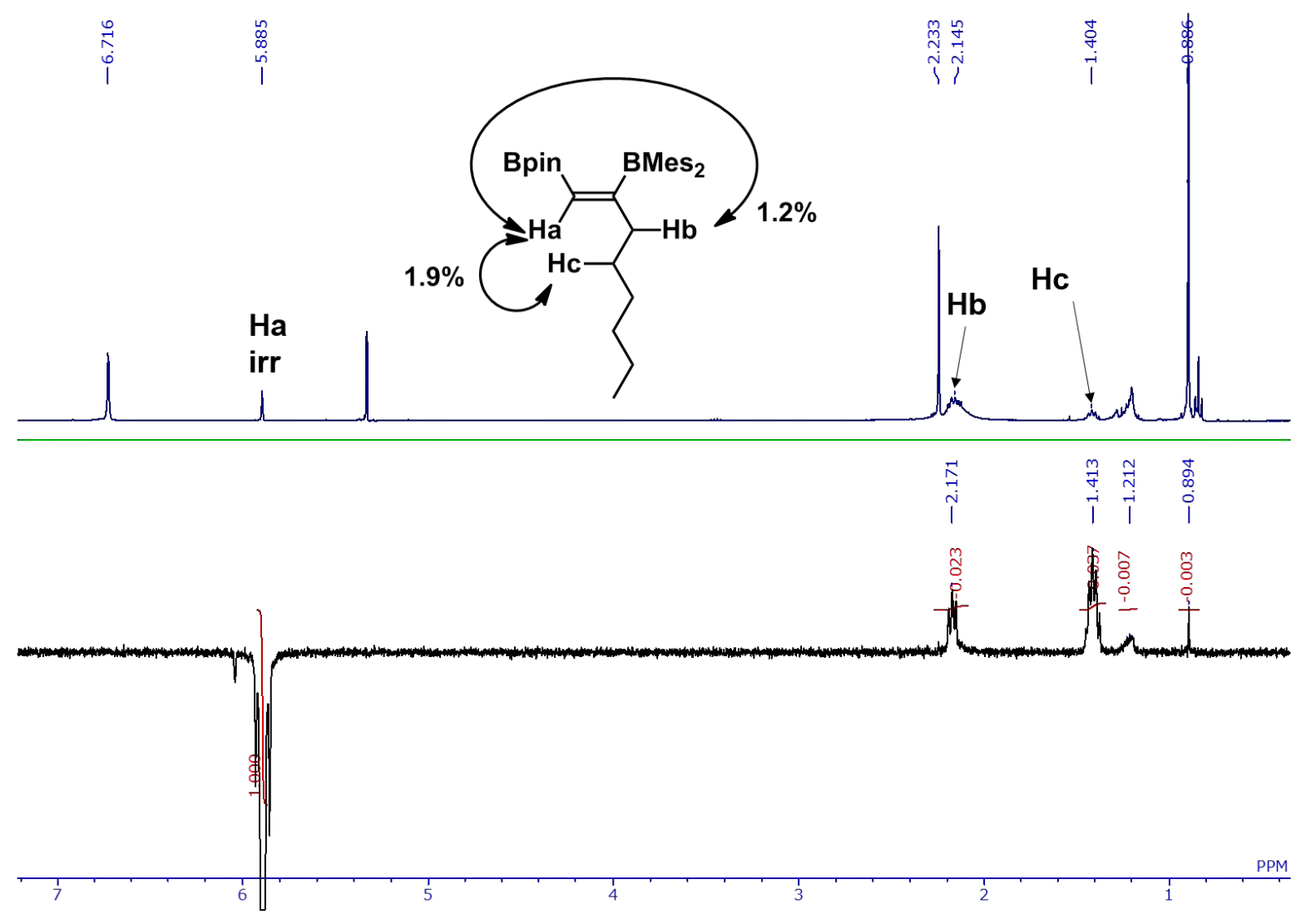

Figure S72. The differential ${ }^{1} \mathrm{H}$ NOE spectrum $\left(\mathrm{C}_{6} \mathrm{D}_{6}\right)$ of $\mathbf{3 G a}$ with irradiation to the signal of vinylic $\mathrm{H}_{\mathrm{a}}$

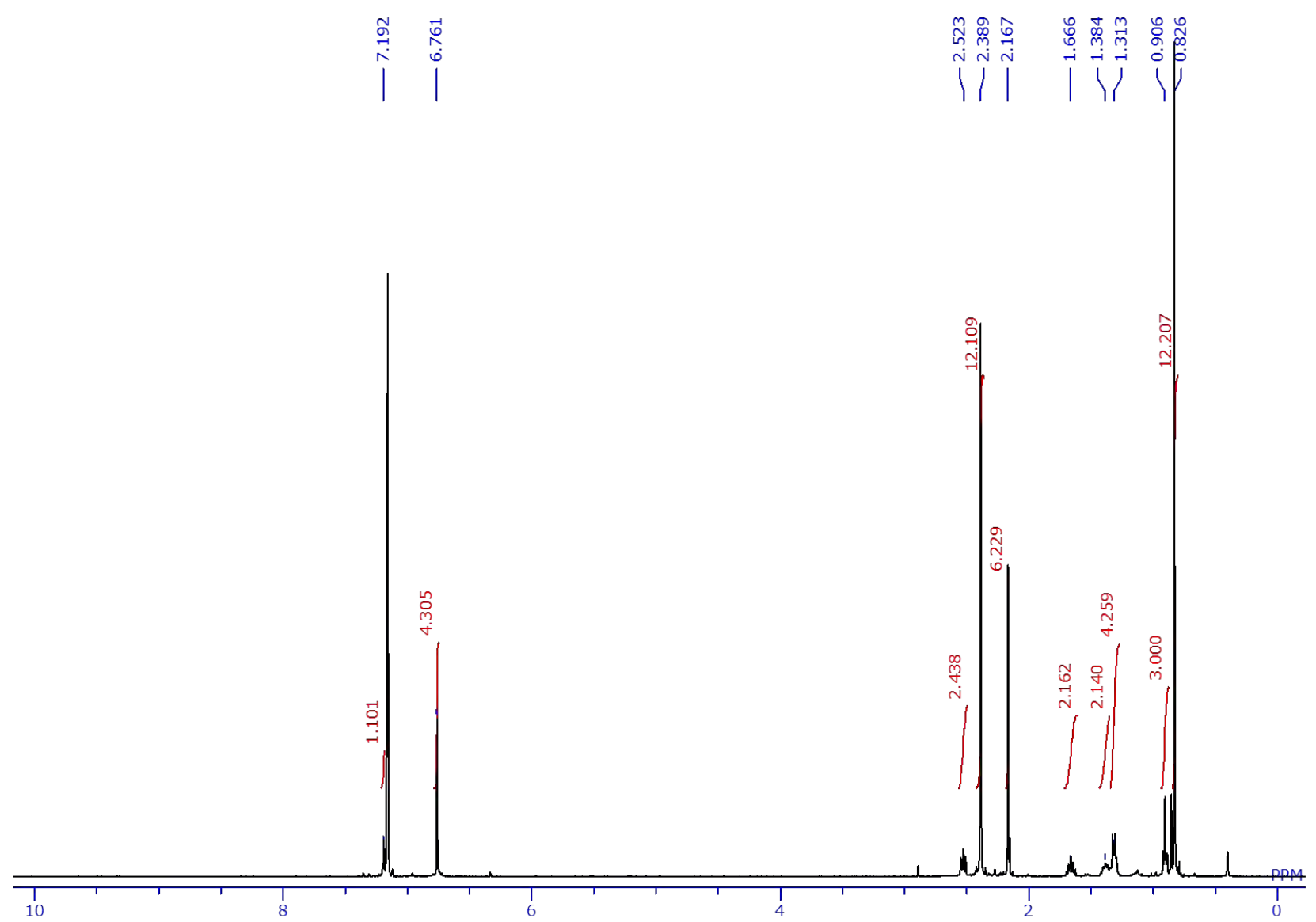

Figure S73. The ${ }^{1} \mathrm{H}$ NMR spectrum $\left(\mathrm{C}_{6} \mathrm{D}_{6}\right)$ of $\mathbf{3 G b}$ 


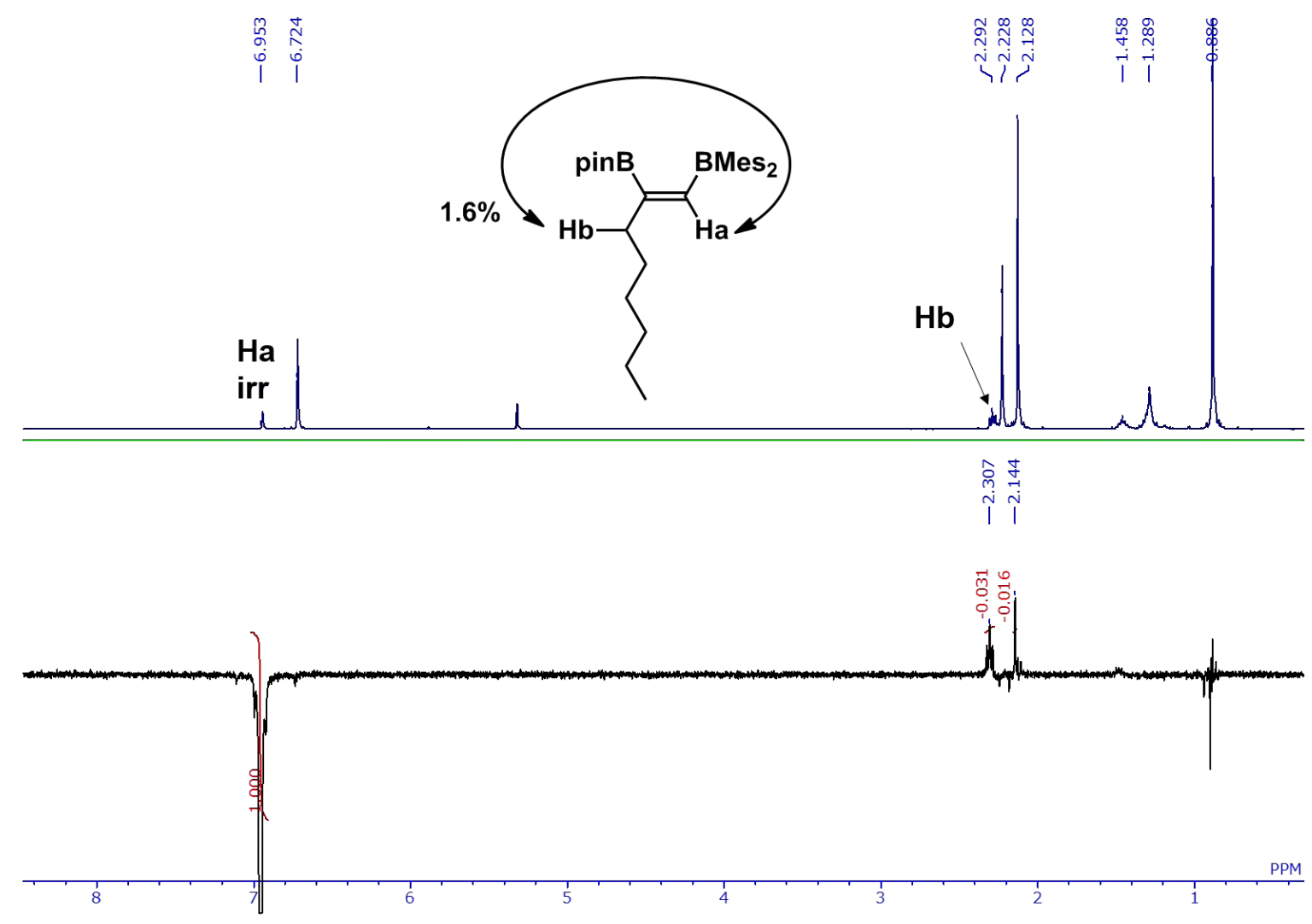

Figure S74. The differential ${ }^{1} \mathrm{H}$ NOE spectrum $\left(\mathrm{C}_{6} \mathrm{D}_{6}\right)$ of $\mathbf{3 G b}$ with irradiation to the signal of vinylic $\mathrm{H}_{\mathrm{a}}$ 


\section{NMR yield of $3 \mathrm{Ga}$ and $3 \mathrm{~Gb}$ in run 13 , Table 2}

The procedure described in run 1, Table 1 was used. Reaction condition: Toluene (500 $\mu \mathrm{L}), 1$ (75.2 mg, 0.200 mmol), 1-octyne $(38.8 \mu \mathrm{L}, 0.220 \mathrm{mmol}), 100{ }^{\circ} \mathrm{C}, 4 \mathrm{~h}$, trimethoxybenzene $(16.8 \mathrm{mg}, 0.100 \mathrm{mmol})$, crude $(95.7$ mg); NMR yield: 3Ga, 64\%; 3Gb, 33\%. See Figure S75 for the ${ }^{1} \mathrm{H}$ NMR spectrum of the crude product.

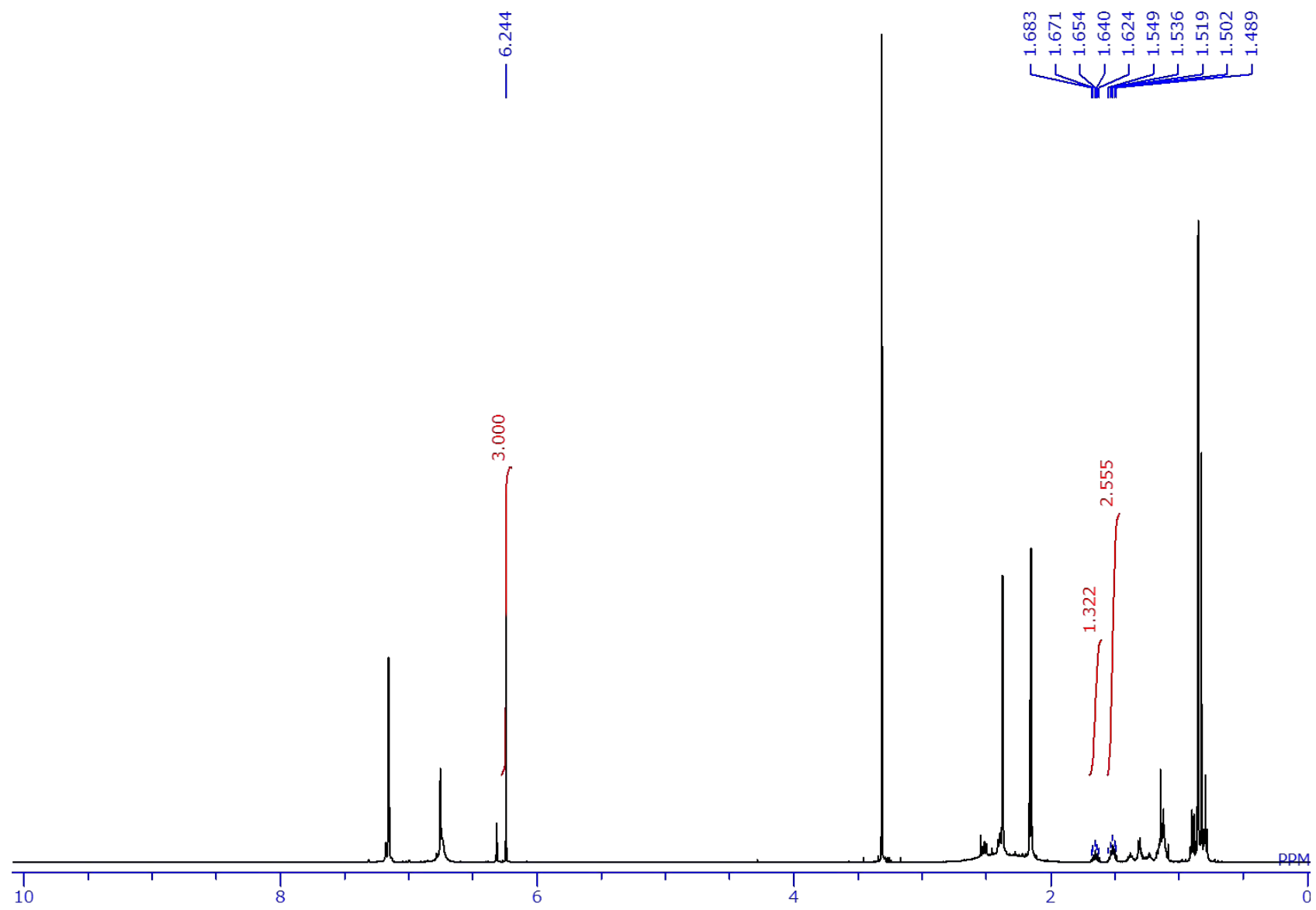

Figure S75. The ${ }^{1} \mathrm{H}$ NMR spectrum of the reaction mixture in run 13, Table 2 (1.52 ppm: 3Ga; 1.66 ppm: 3Gb; 6.24 ppm: internal standard, 1,3,5-trimethoxybenzene) 


\section{Base-catalyzed reaction of 1 with 1-octyne (Table 2, run 14)}

Because 3Gc was not isolated, the following NMR experiment was examined to afford a tentative assignment of 3Gc.

NMR yield of $3 \mathrm{Ga}, 3 \mathrm{~Gb}$ and $3 \mathrm{Gc}$, in run 14 , Table 2

The procedure described in run 9, Table 1 was used. Reaction condition: Toluene (500 $\mu \mathrm{L}), 1$ (75.0 mg, 0.200 mmol ), 1-octyne (32.3 $\mu \mathrm{L}, 0.220 \mathrm{mmol}){ }^{n} \mathrm{BuLi}(0.100 \mathrm{M}$ diluted in toluene, $60.0 \mu \mathrm{L}, 6.00 \mu \mathrm{mol})$, DME (0.100 M diluted in toluene, $60.0 \mu \mathrm{L}, 6.00 \mu \mathrm{mol}), 100{ }^{\circ} \mathrm{C}, 2 \mathrm{~h}$, trimethoxybenzene (10.3 mg, $\left.61.3 \mu \mathrm{mol}\right)$, crude (94.3 mg); NMR yield: 3Ga, 57\%; 3Gb, 29\%; 3Gc, 5\%. See Figures S76 and S77 for NMR spectrum of the crude product. In this reaction, $\mathbf{3 G c}$ could not be completely isolated but was tentatively assigned.

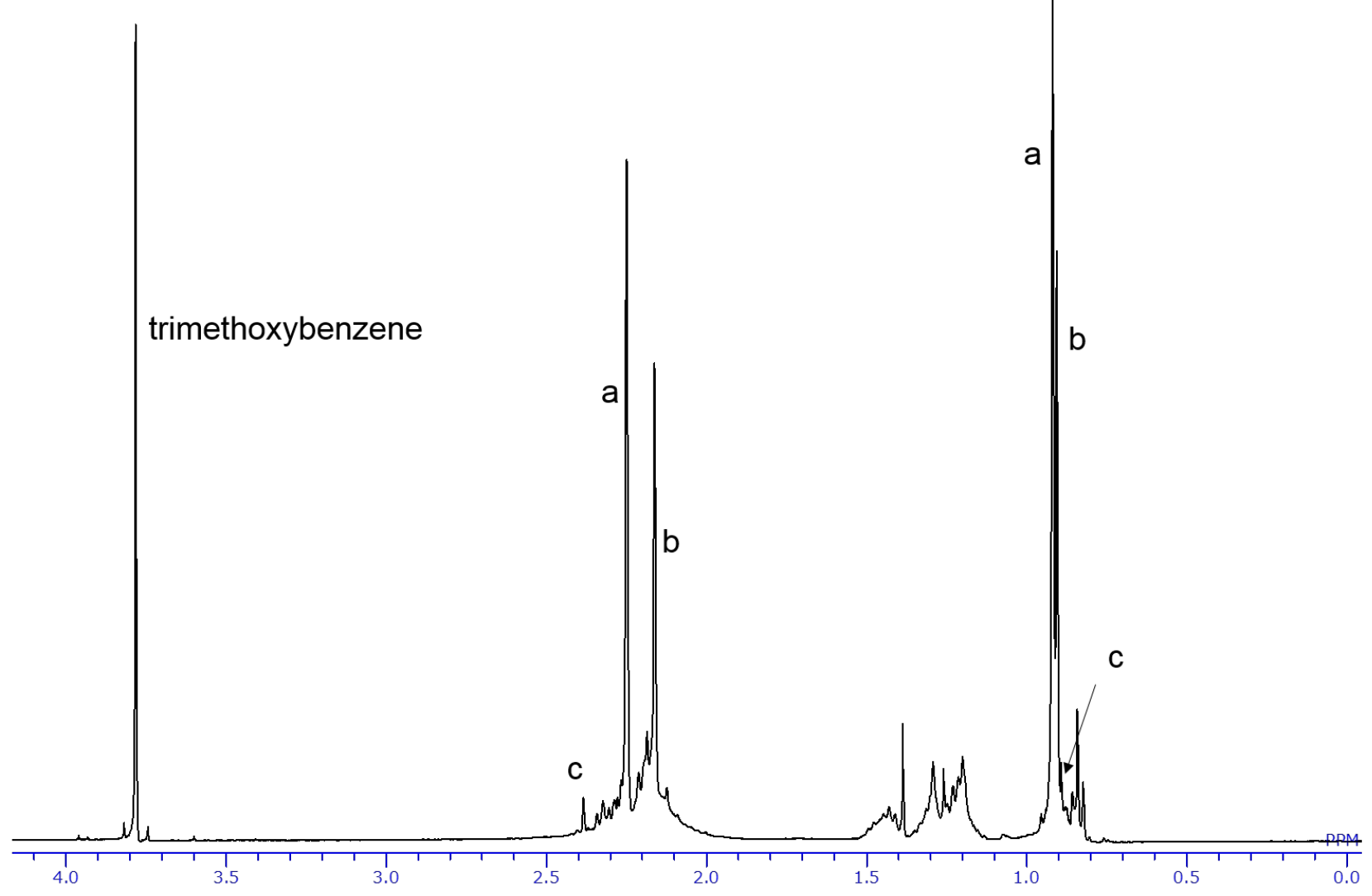

Figure S76. The low-field region of the ${ }^{1} \mathrm{H}$ NMR spectrum $\left(\mathrm{C}_{6} \mathrm{D}_{6}\right)$ for the reaction mixture of run 14 


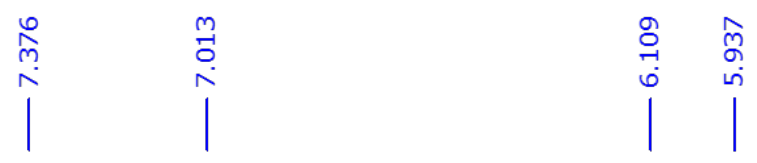

\section{trimethoxybenzene}

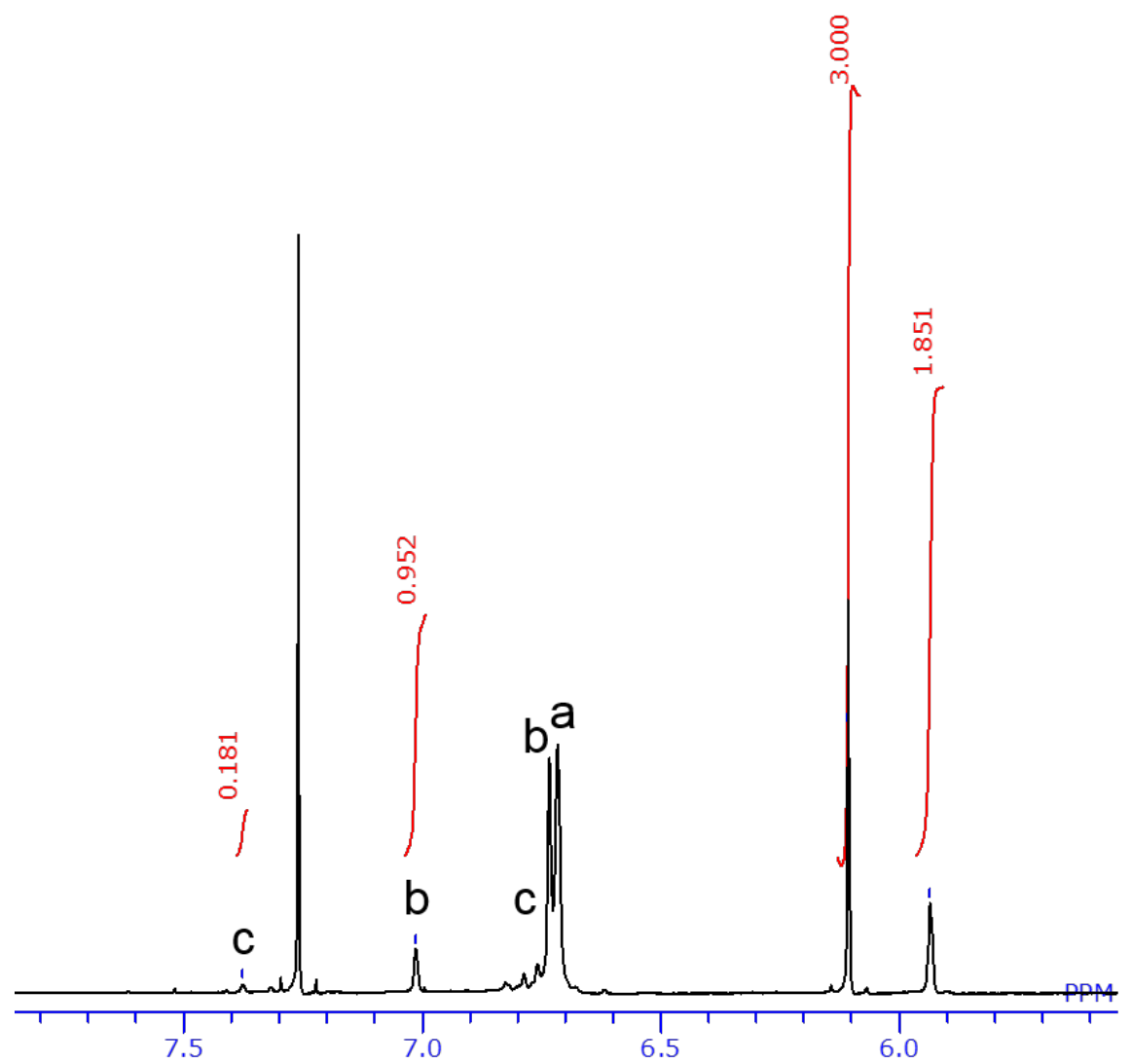

Figure S77. The high-field region of the ${ }^{1} \mathrm{H}$ NMR spectrum $\left(\mathrm{C}_{6} \mathrm{D}_{6}\right)$ for the reaction mixture of run 14 


\section{Direct reaction of 1 with cyclohexylacetylene (Table 2, run 15)}

In a glovebox, to a toluene solution $(1.25 \mathrm{~mL})$ of $1(188 \mathrm{mg}, 0.500 \mathrm{mmol})$ in a $10 \mathrm{~mL} \mathrm{~J}$-young tube, cyclohexylacetylene $(71.8 \mu \mathrm{L}, 0.550 \mathrm{mmol})$ was added. After stirring the reaction mixture at $100{ }^{\circ} \mathrm{C}$ for $9 \mathrm{~h}$, volatiles were removed from the clear solution in vacuo. Single crystals of $\mathbf{3 H a}$ and $\mathbf{3 H b}$ suitable for X-ray diffraction analysis were obtained by slow evaporation of its hexane solution to the coexistent silica-gel in a capped vial at room temperature. Both $\mathbf{3 H a}$ and $\mathbf{3 H b}$ were structurally characterized by X-ray diffraction analysis. Dissolution of single crystals of $\mathbf{3 H b}$, which was confirmed to have the same lattice parameters of the crystallographically characterized $3 \mathbf{H b}$, into $\mathrm{CD}_{2} \mathrm{Cl}_{2}$ enabled us to assign a singlet signal at $6.91 \mathrm{ppm}$ in ${ }^{1} \mathrm{H} \mathrm{NMR}$ spectrum as a vinylic proton of $\mathbf{3 H b}$, although the aliphatic region of the resulting spectrum was not clean due to the existence of mineral oil for treatment of crystals to be mounted on the diffractometer. The crude mixture was also characterized by high-resolution mass spectrum. HRMS (ESI+) Calcd for $\mathrm{C}_{32} \mathrm{H}_{46} \mathrm{~B}_{2} \mathrm{O}_{2}$ : 484.3684, found: 484.3698 .

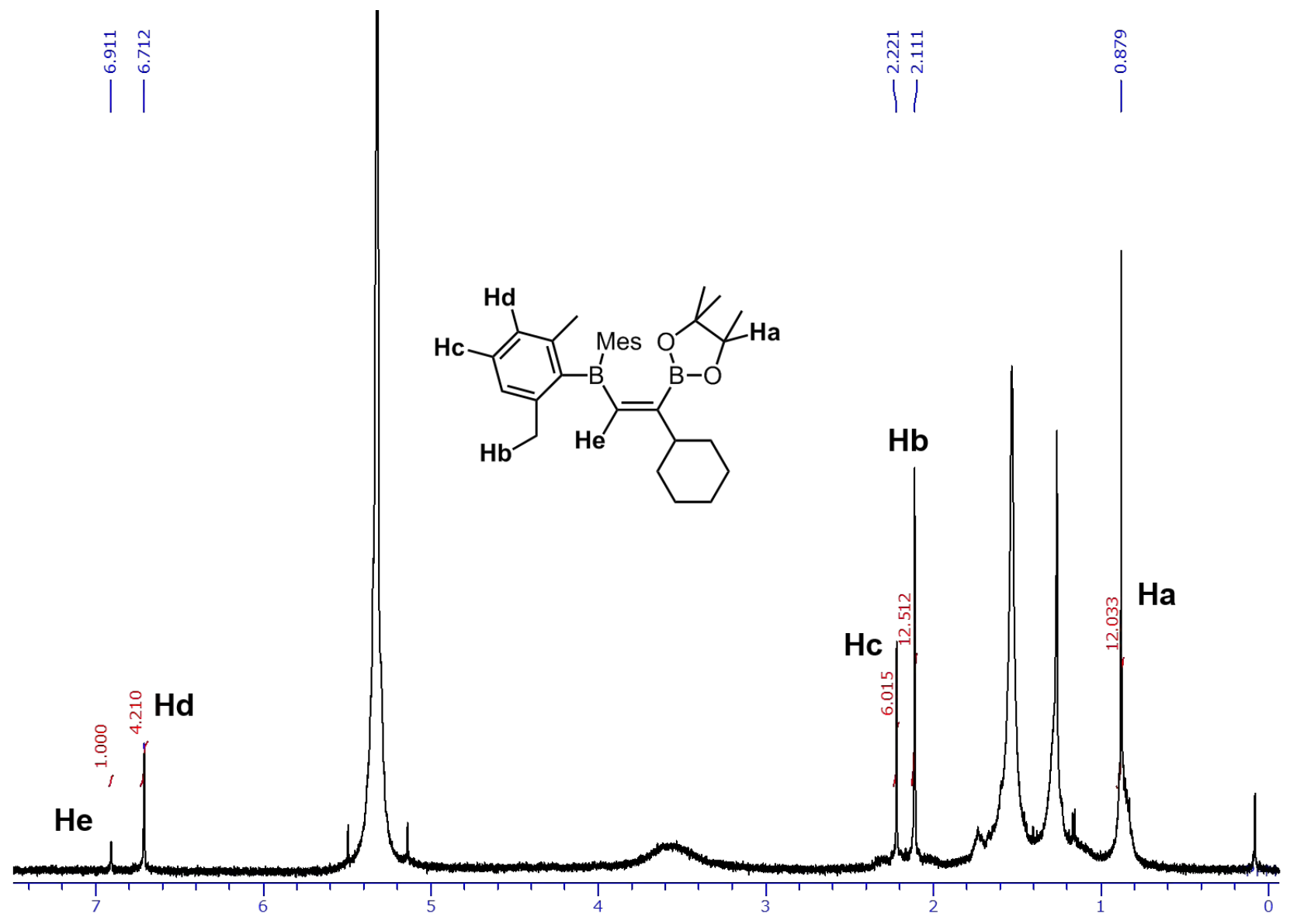

Figure S78. The ${ }^{1} \mathrm{H}$ NMR spectrum $\left(\mathrm{CD}_{2} \mathrm{Cl}_{2}\right)$ of $\mathbf{3 H b}$ including mineral oils 


\section{NMR yield of $3 \mathrm{Ha}$ and $3 \mathrm{Hb}$ in run 15 , Table 2}

The procedure described in run 1, Table 1 was used. Reaction condition: Toluene (500 $\mu \mathrm{L}), 1$ (75.2 mg, 0.200 $\mathrm{mmol})$, cyclohexylacetylene $(28.7 \mu \mathrm{L}, 0.220 \mathrm{mmol}), 100{ }^{\circ} \mathrm{C}, 9 \mathrm{~h}$, trimethoxybenzene $(16.4 \mathrm{mg}, 0.0976 \mathrm{mmol})$, crude (100.9 mg); NMR yield: 3Ha, 40\%; 3Hb, 50\%. See Figure S79 for the ${ }^{1} \mathrm{H}$ NMR spectrum of the crude product.

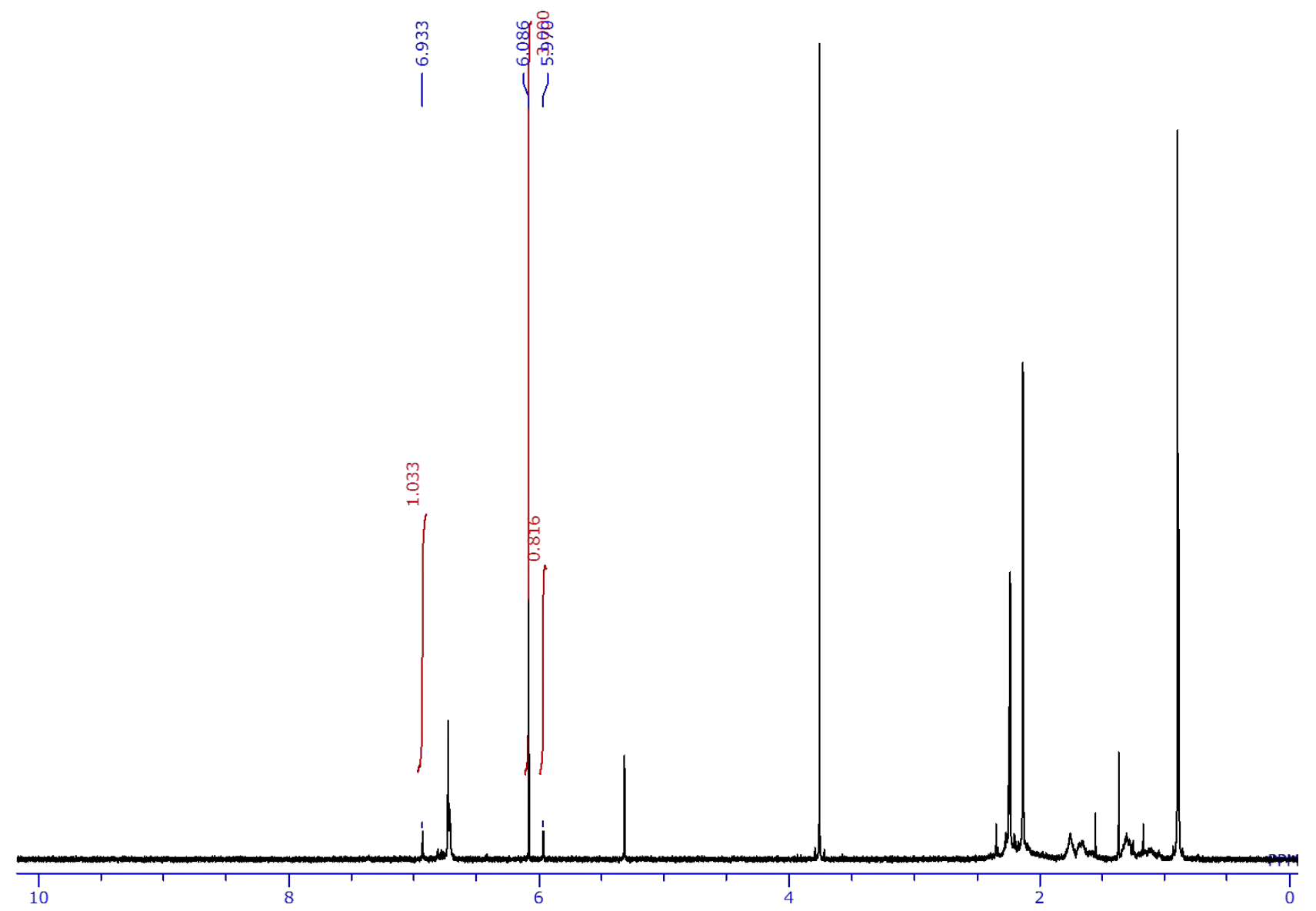

Figure S79. The ${ }^{1} \mathrm{H}$ NMR spectrum of the reaction mixture in run 15, Table 2 (5.97 ppm: 3Ha; 6.93 ppm: 3Hb; 6.07 ppm: internal standard, 1,3,5-trimethoxybenzene) 


\section{Base-catalyzed reaction of 1 with cyclohexylacetylene (Table 2, run 16)}

In a glovebox, to a solution of cyclohexylacetylene $(28.7 \mu \mathrm{L}, 0.220 \mathrm{mmol})$ in toluene $(500 \mu \mathrm{L}),{ }^{n} \mathrm{BuLi}(0.100 \mathrm{M}$ diluted in toluene, $60 \mu \mathrm{L}, 6.00 \mu \mathrm{mol}$ ) was added dropwise at room temperature. After stirring the reaction mixture at room temperature for $3 \mathrm{~min}, \mathbf{1}(75.2 \mathrm{mg}, 0.200 \mathrm{mmol})$ and DME $(0.100 \mathrm{M}$ diluted in toluene, $60 \mu \mathrm{L}, 6.00 \mu \mathrm{mol})$ were added to the reaction mixture at room temperature. After the reaction mixture stirred at $100{ }^{\circ} \mathrm{C}$ for $4 \mathrm{~h}$, volatiles were removed from the pale yellow solution in vacuo.

\section{NMR yield of $3 \mathrm{Ha}, 3 \mathrm{Hb}$ and $3 \mathrm{Hc}$, in run 16 , Table 2}

The procedure described in run 9, Table 1 was used. Reaction condition: Toluene (500 $\mu \mathrm{L}), 1$ (75.0 mg, 0.200 $\mathrm{mmol}$ ), cyclohexylacetylene $(28.7 \mu \mathrm{L}, 0.220 \mathrm{mmol}),{ }^{n} \mathrm{BuLi}(0.100 \mathrm{M}$ diluted in toluene, $60.0 \mu \mathrm{L}, 6.00 \mu \mathrm{mol})$, DME $(0.100 \mathrm{M}$ diluted in toluene, $60.0 \mu \mathrm{L}, 6.00 \mu \mathrm{mol}), 100{ }^{\circ} \mathrm{C}, 4 \mathrm{~h}$, trimethoxybenzene $(12.4 \mathrm{mg}, 73.8 \mu \mathrm{mol})$, crude (83.6 mg); NMR yield: 3Ha, 50\%; 3Hb, 37\%; See Figure S80 for NMR spectrum of the crude product. In this reaction,

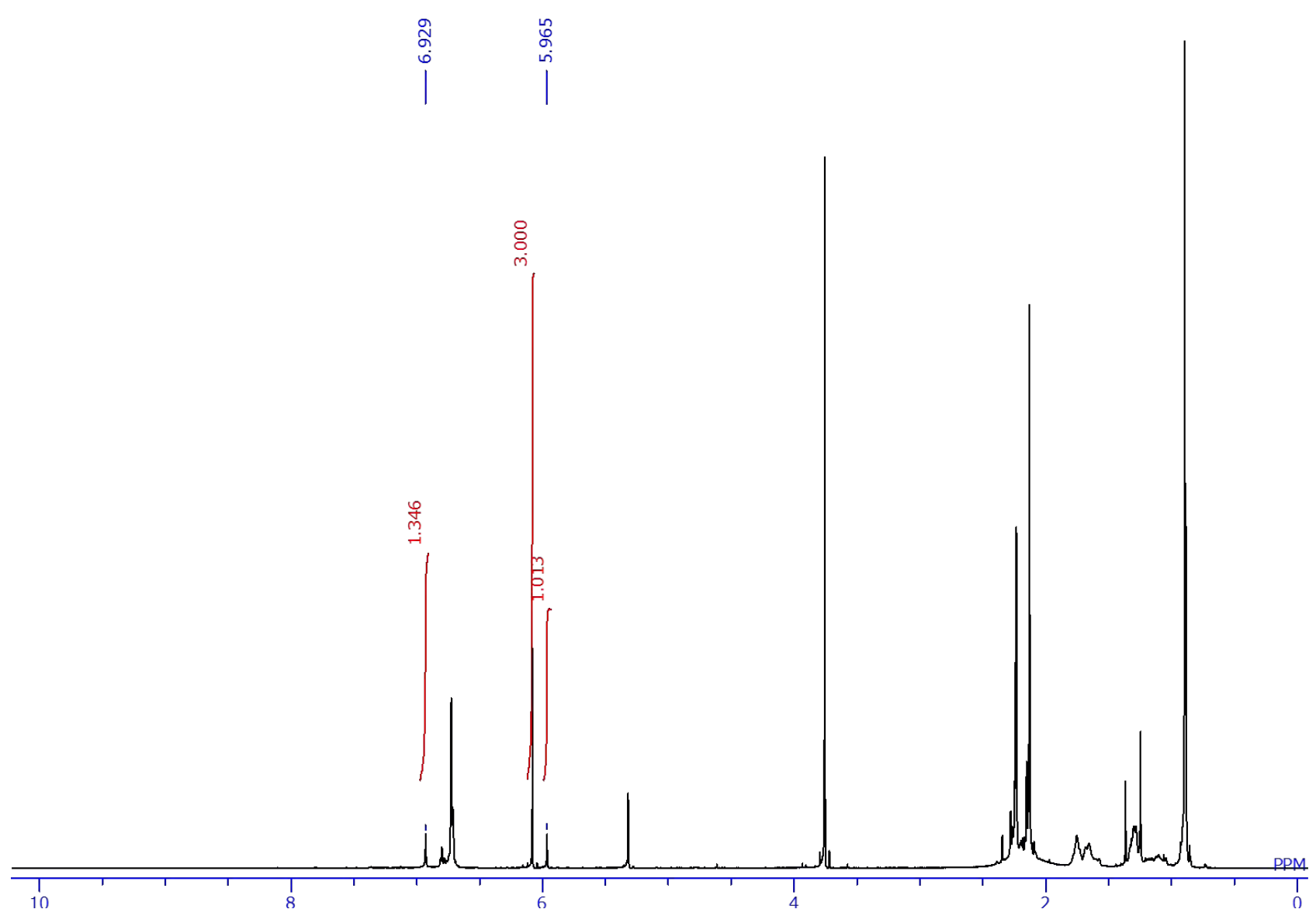

Figure S80. The ${ }^{1} \mathrm{H}$ NMR spectrum of the reaction mixture in run 14, Table 2 (5.97 ppm: 3Ha; 6.93 ppm: 3Hb; 6.07 ppm: internal standard, 1,3,5-trimethoxybenzene) 


\section{Reaction of 1 with internal alkynes (Scheme 5)}

\section{Reaction of 1 with 4-octyne}

In a glovebox, to a toluene solution $(3.00 \mathrm{~mL})$ of $1(226 \mathrm{mg}, 0.600 \mathrm{mmol})$ in a $10 \mathrm{~mL}$ J-young tube, 4-octyne $(96.5 \mu \mathrm{L}, 0.660 \mathrm{mmol})$ was added. After stirring the reaction mixture at $100{ }^{\circ} \mathrm{C}$ for $132 \mathrm{~h}$, volatiles were removed from the reaction mixture in vacuo. Purification of the residue by recrystallization with toluene afforded colorless crystals of 4 (126 mg, $0.259 \mathrm{mmol}, 43 \%) .{ }^{1} \mathrm{H}$ NMR $\left(500 \mathrm{MHz}, \mathrm{C}_{6} \mathrm{D}_{6}, 70{ }^{\circ} \mathrm{C}\right) \delta 0.76\left(\mathrm{t}, J=7 \mathrm{~Hz}, 3 \mathrm{H}, \mathrm{CH}_{3}\right), 0.83$ (br s, $12 \mathrm{H}$, pin- $\mathrm{CH}_{3}$ ), 1.04 (t, $J=7 \mathrm{~Hz}, 3 \mathrm{H}, \mathrm{CH}_{3}$ ), 1.43 (br s, 2H, $\mathrm{CH}_{2}$ ), 1.69 (m, 2H, $\mathrm{CH}_{2}$ ), 1.83-2.87 (br s, 12H, $o-\mathrm{CH}_{3}$ ), 2.15 (br s, $6 \mathrm{H}, p-\mathrm{CH}_{3}$ ), 2.39 (br t, $J=9 \mathrm{~Hz}, 2 \mathrm{H}, \mathrm{CH}_{2}$ ), 2.50 (br t, $J=9 \mathrm{~Hz}, 2 \mathrm{H}, \mathrm{CH}_{2}$ ), 6.71 (br s, $4 \mathrm{H}, \mathrm{ArH}$ of Mes); ${ }^{11} \mathrm{~B}$ NMR (161 MHz, $\left.\mathrm{C}_{6} \mathrm{D}_{6}\right) \delta 30$ (br s), 75 (br s); ${ }^{13} \mathrm{C}$ NMR $\left(126 \mathrm{MHz}, \mathrm{C}_{6} \mathrm{D}_{6}, 70{ }^{\circ} \mathrm{C}\right) \delta 15.0\left(\mathrm{CH}_{3}\right), 15.4$ $\left(\mathrm{CH}_{3}\right), 21.2\left(\mathrm{CH}_{3}\right), 22.9$ (br s, $\left.\mathrm{CH}_{3}\right), 23.0\left(\mathrm{CH}_{2}\right), 24.3\left(\mathrm{CH}_{2}\right), 24.6$ (br s, $\left.\mathrm{CH}_{3}\right), 35.4\left(\mathrm{CH}_{2}\right), 35.9\left(\mathrm{CH}_{2}\right), 83.1\left(4^{\circ}\right)$, 128.6 (CH), $129.2(\mathrm{CH}), 137.7\left(\right.$ br s, $\left.4^{\circ}\right), 139.7\left(\right.$ br s, $\left.4^{\circ}\right), 143.7\left(\right.$ br s, $\left.4^{\circ}\right), 144.1\left(\right.$ br s, $\left.4^{\circ}\right), 145.0\left(\right.$ br s, $\left.4^{\circ}\right), 162.4$ (br s, $4^{\circ}$ ); mp 84-86 ${ }^{\circ} \mathrm{C}$; Anal. Calcd for $\mathrm{C}_{32} \mathrm{H}_{48} \mathrm{~B}_{2} \mathrm{O}_{2}$ : C, 79.03; H, 9.95; Found: C, 79.11; H, 9.57.

\section{NMR yield of 4}

The procedure described in run 1, Table 1 was used. Reaction condition: Toluene $(1.00 \mathrm{~mL}), \mathbf{1}(75.2 \mathrm{mg}, 0.200$ mmol ), 4-octyne (32.5 $\mu \mathrm{L}, 0.220 \mathrm{mmol}), 100{ }^{\circ} \mathrm{C}, 5.5 \mathrm{~d}$, trimethoxybenzene (16.4 mg, $\left.97.6 \mu \mathrm{mol}\right)$, crude (99.1 $\mathrm{mg}$ ); NMR yield of 4, 82\%; See Figure S81 for NMR spectrum of the crude product.

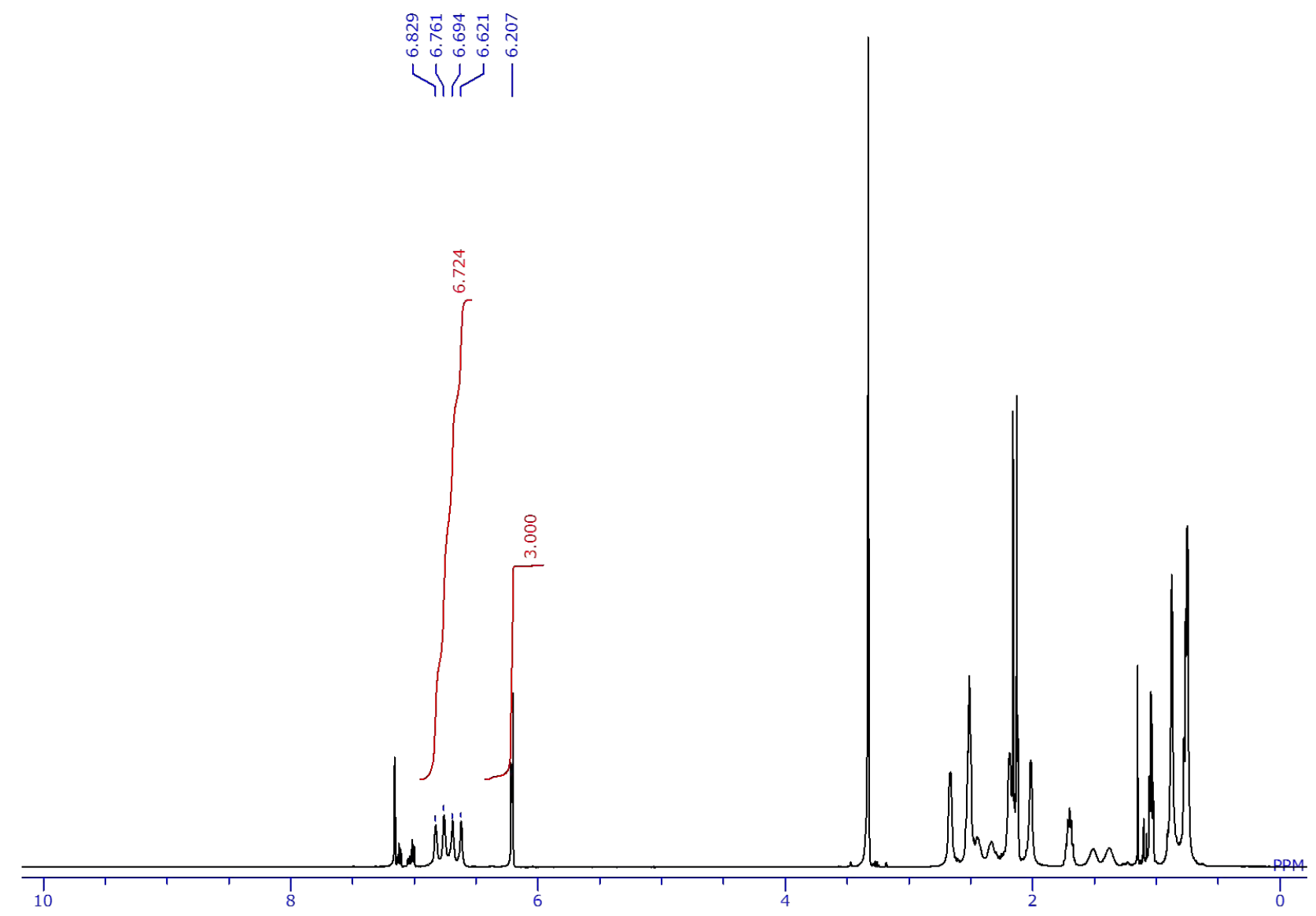

Figure S81. The ${ }^{1} \mathrm{H}$ NMR spectrum of the reaction mixture in Scheme (6.62-6.83 ppm: 4; $6.21 \mathrm{ppm}$ : internal standard, 1,3,5-trimethoxybenzene) 


\section{Reaction of 1 with 1-phenylpropyne}

In a glovebox, to a toluene solution $(1.0 \mathrm{~mL})$ of $1(564 \mathrm{mg}, 1.50 \mathrm{mmol})$ in a $10 \mathrm{~mL}$ J-young tube, 1-Phenyl-1-propyne $(210 \mu \mathrm{L}, 1.65 \mathrm{mmol})$ was added. After stirring the reaction mixture at $100{ }^{\circ} \mathrm{C}$ for 7 days, volatiles were removed from the reaction mixture in vacuo. Purification of the residue by recrystallization with hexane/toluene $(10: 1, \mathrm{v} / \mathrm{v})$ afforded clear crystals of $\mathbf{5 a}(417 \mathrm{mg}, 0.847 \mathrm{mmol}, 56 \%)$ and purification of the residue by recycling GPC (16 cycles) afforded clear oil of $\mathbf{5 b}(45.6 \mathrm{mg}, 92.6 \mu \mathrm{mol}, 6 \%) . \mathbf{5 a}:{ }^{1} \mathrm{H}$ NMR $\left(500 \mathrm{MHz}, \mathrm{C}_{6} \mathrm{D}_{6}\right) \delta$ 0.83 (brs, 12H, pin- $\mathrm{CH}_{3}$ ), 2.09 (s, 3H, Me), 2.11 (s, 6H, $p-\mathrm{CH}_{3}$ ), 2.64 (br, 12H, o- $\mathrm{CH}_{3}$ ), 6.69 (brs, $4 \mathrm{H}, \mathrm{ArH}$ of Mes), 6.91 (t, $J=7 \mathrm{~Hz}, 1 \mathrm{H}, \mathrm{ArH}$ of Ph), 7.06 (t, $J=8 \mathrm{~Hz}, 2 \mathrm{H}, \mathrm{ArH}$ of Ph), 7.24 (d, $J=8 \mathrm{~Hz}, 2 \mathrm{H}, \mathrm{ArH}$ of Ph); ${ }^{11} \mathrm{~B}$ NMR (161 MHz, $\left.\mathrm{C}_{6} \mathrm{D}_{6}\right) \delta 30$ (br s), 77 (br s); ${ }^{13} \mathrm{C}$ NMR (126 MHz, $\left.\mathrm{CD}_{2} \mathrm{Cl}_{2}\right) \delta 20.9\left(\mathrm{CH}_{3}\right), 21.3\left(\mathrm{CH}_{3}\right), 23.5\left(\mathrm{CH}_{3}\right)$, $24.7\left(\mathrm{CH}_{3}\right), 83.7\left(4^{\circ}\right), 125.8\left(\mathrm{CH}_{3}\right), 127.7(\mathrm{CH}), 128.5(\mathrm{CH}), 129.2(\mathrm{CH}), 139.3\left(\mathrm{br}, 4^{\circ}\right), 143.5\left(\mathrm{br}, 4^{\circ}\right.$, bonding to the B nucleus), 143.7 (br, $\left.4^{\circ}\right), 143.9\left(4^{\circ}\right), 145.0\left(\mathrm{br}, 4^{\circ}\right), 162.0$ (br, $4^{\circ}$, bonding to the B nucleus); $\mathrm{mp} 144-147^{\circ} \mathrm{C}$; Anal. Calcd for $\mathrm{C}_{33} \mathrm{H}_{42} \mathrm{~B}_{2} \mathrm{O}_{2}$ : C, 80.51; H, 8.60; Found: C, 80.17; H, 8.97; 5b: ${ }^{1} \mathrm{H}$ NMR $\left(500 \mathrm{MHz}, \mathrm{C}_{6} \mathrm{D}_{6}\right) \delta 0.83$ (brs, 12H, pin- $\mathrm{CH}_{3}$ ), 2.09 (s, 3H, Me), $2.11\left(\mathrm{~s}, 6 \mathrm{H}, p-\mathrm{CH}_{3}\right), 2.64$ (br, 12H, o- $\mathrm{CH}_{3}$ ), 6.69 (brs, $4 \mathrm{H}, \mathrm{ArH}$ of Mes), $6.91(\mathrm{t}, J=7 \mathrm{~Hz}, 1 \mathrm{H}, \mathrm{ArH}$ of Ph), 7.06 (t, $J=8 \mathrm{~Hz}, 2 \mathrm{H}, \mathrm{ArH}$ of Ph), 7.24 (d, $J=8 \mathrm{~Hz}, 2 \mathrm{H}, \mathrm{ArH}$ of Ph); HRMS (ESI+) Calcd for $\mathrm{C}_{33} \mathrm{H}_{42} \mathrm{~B}_{2} \mathrm{O}_{2}: 492.3371$, found: 492.3377 .

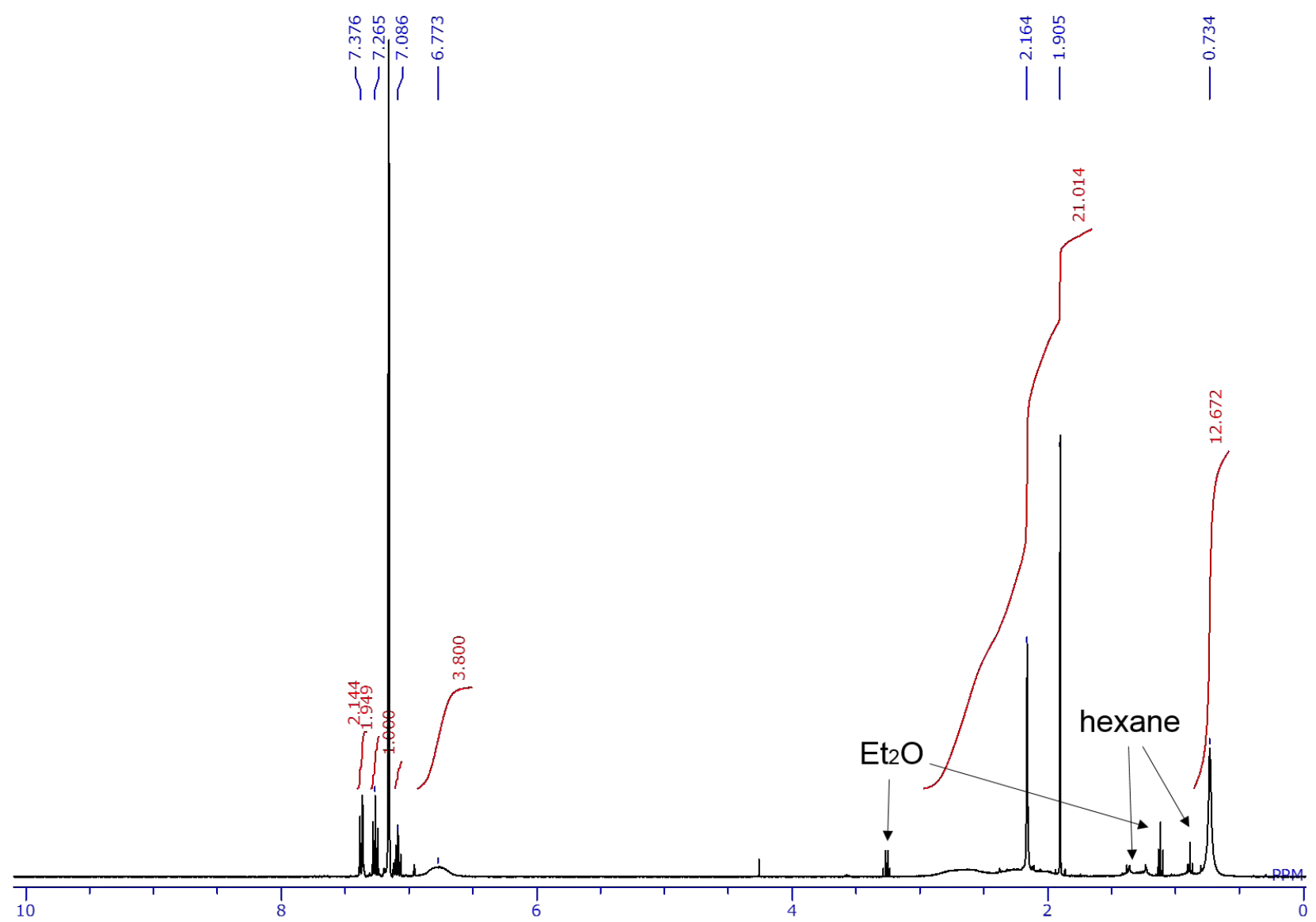

Figure S82. The ${ }^{1} \mathrm{H}$ NMR spectrum $\left(\mathrm{C}_{6} \mathrm{D}_{6}\right)$ of $\mathbf{5 b}$ 


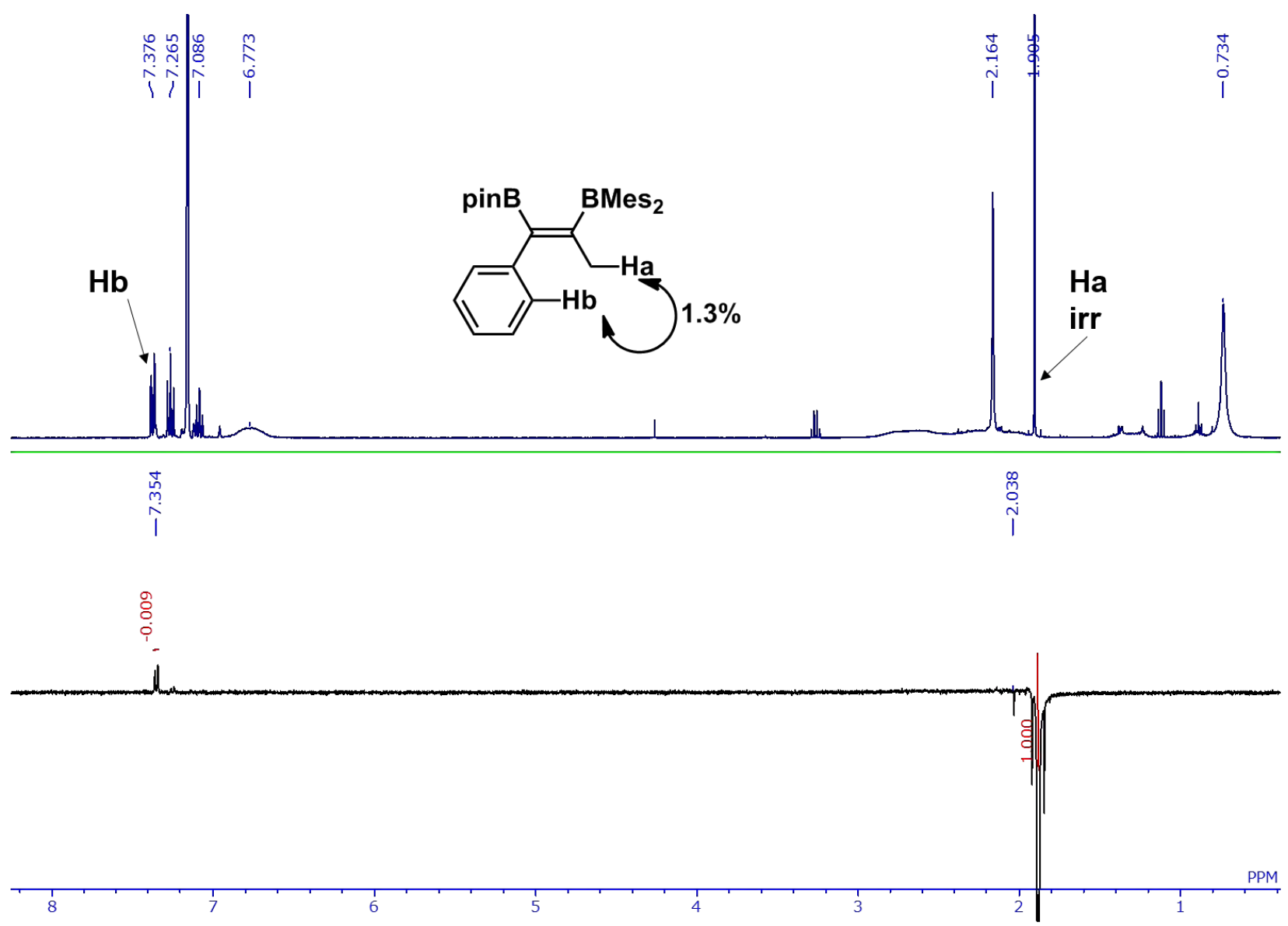

Figure S83. The differential ${ }^{1} \mathrm{H}$ NOE spectrum $\left(\mathrm{C}_{6} \mathrm{D}_{6}\right)$ of $\mathbf{5 b}$ with irradiation to the signal of vinylic $\mathrm{H}_{\mathrm{a}}$ 


\section{NMR yield of 5a and $5 b$}

The procedure described in run 1, Table 1 was used. Reaction condition: Toluene $(250 \mu \mathrm{L}), 1$ (75.2 mg, 0.200 mmol), 1-Phenyl-1-propyne $(27.2 \mu \mathrm{L}, 0.220 \mathrm{mmol}), 100{ }^{\circ} \mathrm{C}, 5.5 \mathrm{~d}$, trimethoxybenzene $(18.5 \mathrm{mg}, 0.110 \mathrm{mmol})$, crude $(99.3 \mathrm{mg}$ ); NMR yield: 5a, 61\%; 5b, 23\%. See Figure S84 for NMR spectrum of the crude product.

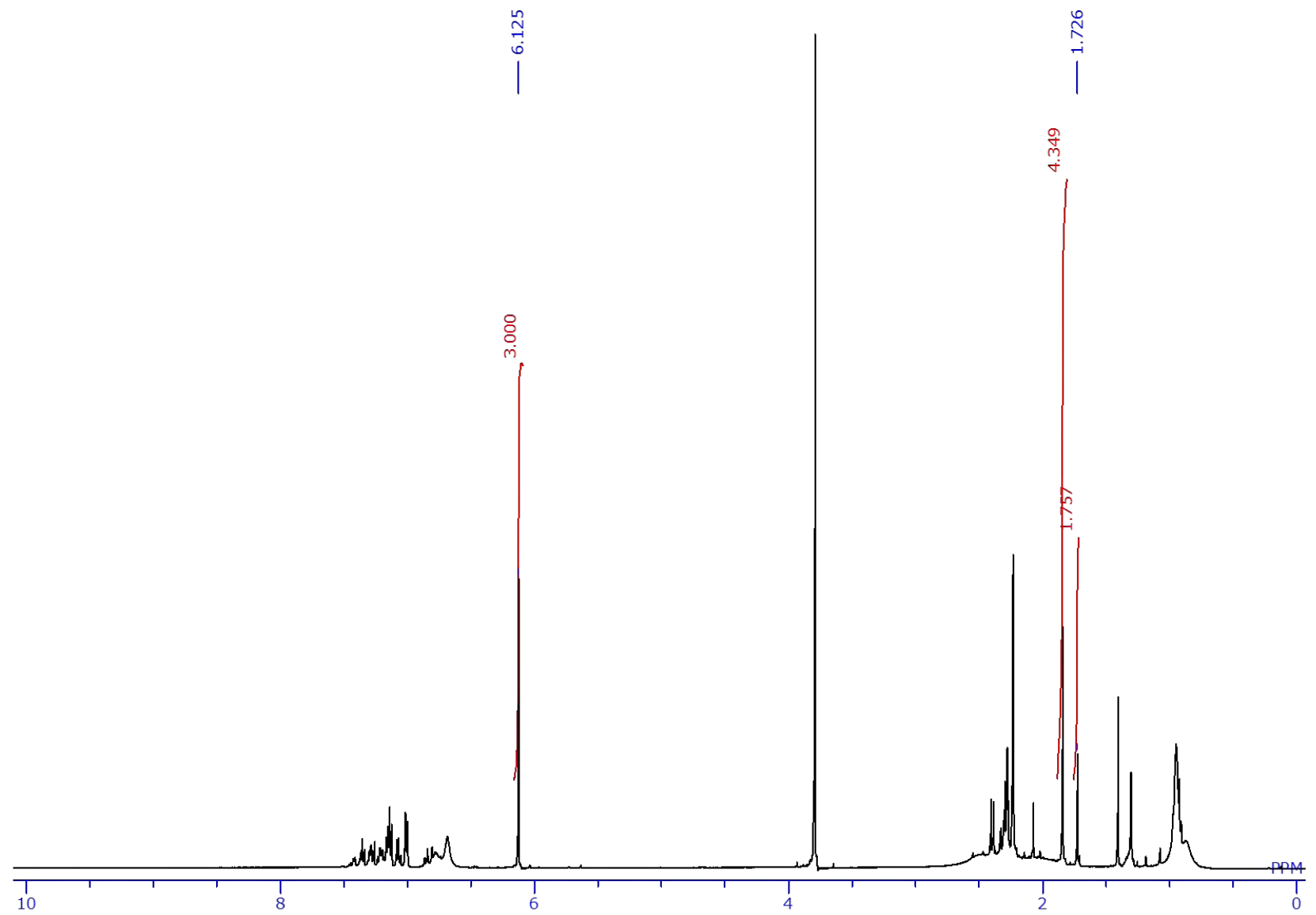

Figure S84. The ${ }^{1} \mathrm{H}$ NMR spectrum of the reaction mixture in Scheme 1 (1.85 ppm: 5a; 1.73 ppm: $5 \mathbf{b} ; 6.13$ ppm: internal standard, 1,3,5-trimethoxybenzene) 


\section{Synthesis and reactivity of potential reaction intermediates (Scheme 6)}

\section{Isolation of $6(\text { thf })_{2}$}

In a glovebox, to a THF solution $(800 \mu \mathrm{L})$ of lithium phenylacetylide $(27.2 \mathrm{mg}, 0.250 \mathrm{mmol})$ was added dropwise a solution of $1(75.2 \mathrm{mg}, 0.200 \mathrm{mmol})$ in THF $(200 \mu \mathrm{L})$ at room temperature. After stirring the reaction mixture at room temperature for $5 \mathrm{~min}$, volatiles were removed from the reaction mixture in vacuo. Purification of the residue by recrystallization with THF afforded colorless crystals of $\mathbf{6}(\mathbf{t h f})_{2}(60.0 \mathrm{mg}, 0.0864 \mathrm{mmol}, 43 \%){ }^{1} \mathrm{H}$ NMR (500 MHz, C $\left.6 \mathrm{D}_{6}\right) \delta 0.98\left(\mathrm{~s}, 12 \mathrm{H}\right.$, pin- $\left.\mathrm{CH}_{3}\right), 1.24$ (m, 12H, THF), $2.36\left(\mathrm{~s}, 6 \mathrm{H}, p-\mathrm{CH}_{3}\right), 2.79\left(\mathrm{~s}, 12 \mathrm{H}, o-\mathrm{CH}_{3}\right)$, 3.38 (m, 12H, THF), 6.95 (m, 3H, Ph), 7.02 (s, 4H, ArH of Mes), 7.18 (m, 2H, Ph); ${ }^{7} \mathrm{Li} \mathrm{NMR}\left(194 \mathrm{MHz} \mathrm{C}_{6} \mathrm{D}_{6}\right) \delta$ 0.52 (s); ${ }^{11} \mathrm{~B}$ NMR (161 MHz, THF $\left.d_{8}\right) \delta-23$ (s), 27 (br s); ${ }^{13} \mathrm{C}$ NMR $\left(126 \mathrm{MHz}, \mathrm{THF} d_{8},-35{ }^{\circ} \mathrm{C}\right) \delta 21.1\left(\mathrm{CH}_{3}\right)$, 24.6 $\left(\mathrm{CH}_{3}\right), 26.2\left(\mathrm{CH}_{2}\right.$ of THF), $26.2\left(\mathrm{CH}_{3}\right), 68.0\left(\mathrm{CH}_{2}\right.$ of THF), $81.9\left(4^{\circ}\right), 96.9\left(4^{\circ}\right), 124.8\left(4^{\circ}\right.$, bonding to the B nucleus) $126.1(\mathrm{CH}), 128.3(\mathrm{CH}), 128.5(\mathrm{CH}), 128.8\left(4^{\circ}\right) 130.3\left(4^{\circ}\right), 130.7(\mathrm{CH}), 141.7\left(4^{\circ}\right), 153.1\left(4^{\circ}\right.$, bonding to the B nucleus); IR (ATR) 2101, $2120 \mathrm{~cm}^{-1}$ (alkyne, see also S118 for DFT-based vibrational analysis); mp 114-116 ${ }^{\circ} \mathrm{C}$ (decomp.); Anal. Calcd for $\mathrm{C}_{44} \mathrm{H}_{63} \mathrm{~B}_{2} \mathrm{LiO}_{5}$ : C, 75.44; H, 9.06; Found: C, 75.75; H, 9.37.

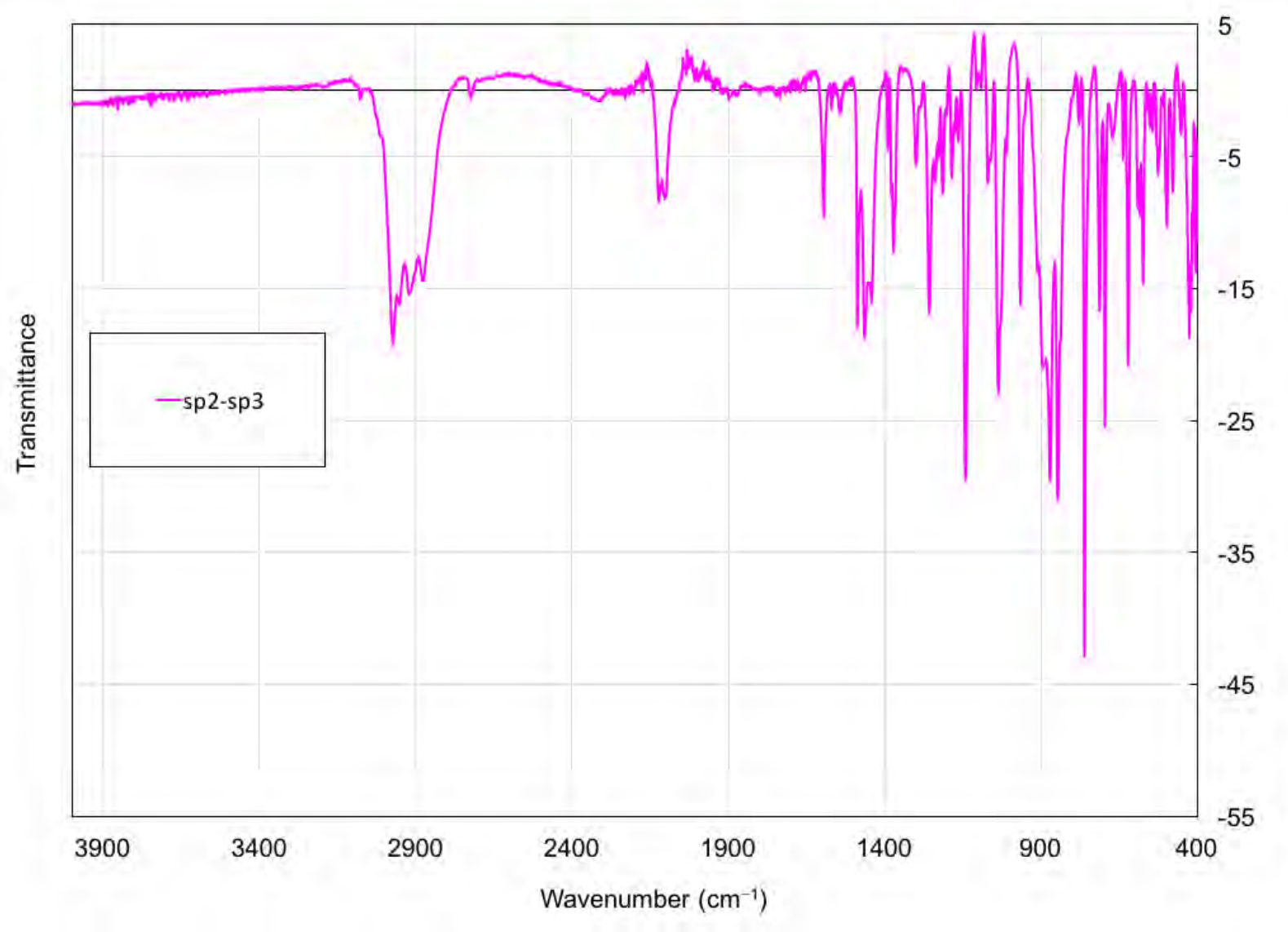

Figure S85. IR spectrum of $\mathbf{6}(\mathbf{t h f})_{2}\left(2101,2120 \mathrm{~cm}^{-1}:\right.$ alkyne) 


\section{NMR yield of $6(\text { thf })_{2}$}

The procedure for isolation was used and the crude mixture was dissolved in $\mathrm{CDCl}_{3}$ to estimate NMR yield. Reaction condition: THF (500 $\mu \mathrm{L}), \mathbf{1}(37.6 \mathrm{mg}, 0.100 \mathrm{mmol})$, lithium phenylacetylide (12.2 $\mathrm{mg}, 0.113 \mathrm{mmol})$, RT, $1 \mathrm{~h}$, trimethoxybenzene $(16.8 \mathrm{mg}, 0.100 \mathrm{mmol})$, crude $(67.5 \mathrm{mg})$; NMR yield: 6(thf) $298 \%$; See Figure S86 for NMR spectrum of the crude product.

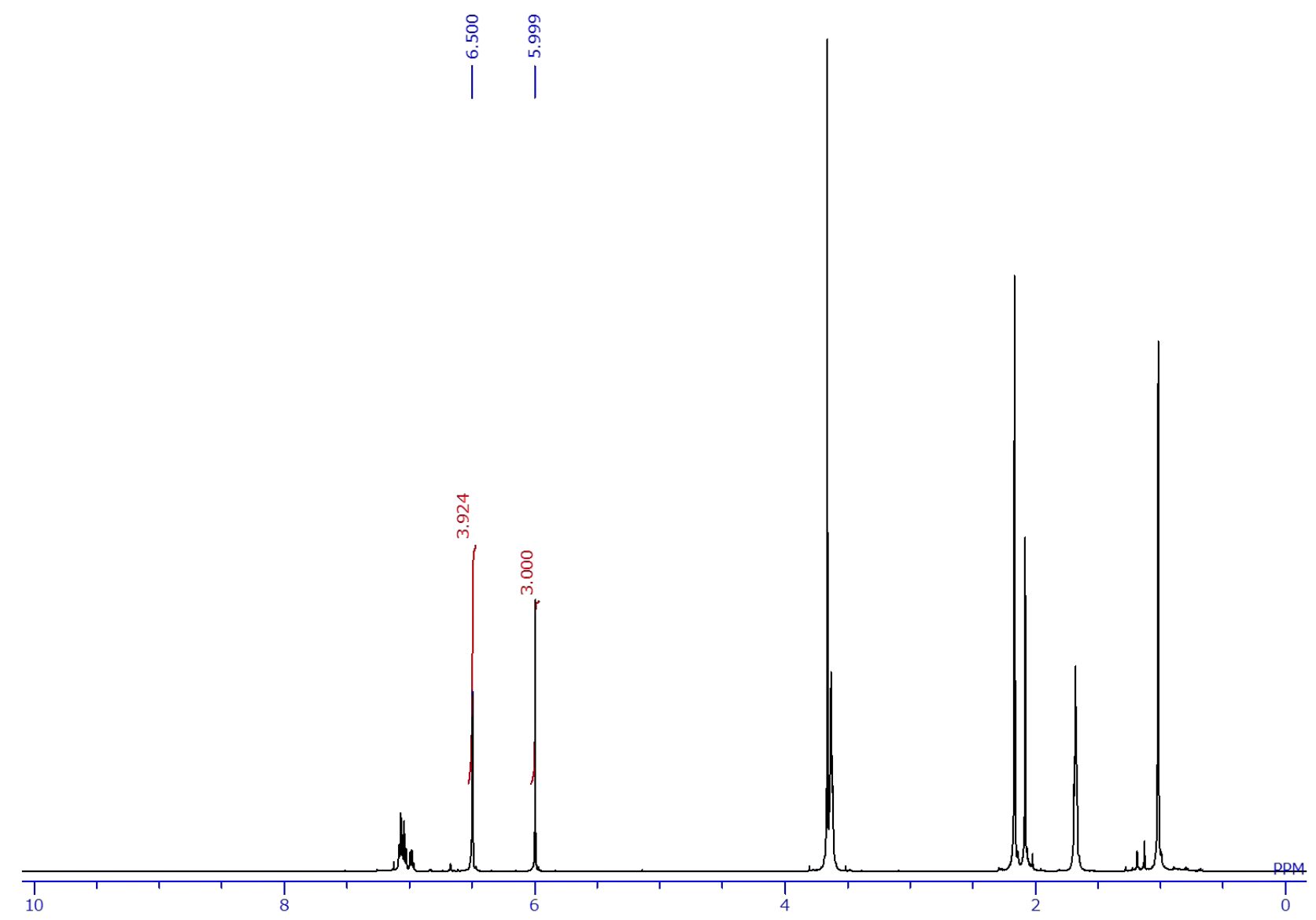

Figure S86. The ${ }^{1} \mathrm{H}$ NMR spectrum of the reaction mixture for the synthesis of $\mathbf{6}(\mathbf{t h f})_{2}\left(6.50 \mathrm{ppm}\right.$ : $\mathbf{6}(\mathbf{t h f})_{2} ; 6.00$ ppm: internal standard, 1,3,5-trimethoxybenzene) 


\section{Isolation of $7(\text { thf })_{2}$}

In a glovebox, to a THF solution $(2.5 \mathrm{~mL})$ of $1(376 \mathrm{mg}, 1.00 \mathrm{mmol})$ in a $10 \mathrm{~mL}$ J-young tube, a THF solution $(2.50 \mathrm{~mL})$ of lithium phenylacetylide $(108 \mathrm{mg}, 1.00 \mathrm{mmol})$ was added at room temperature. The reaction mixture was stirred at $70{ }^{\circ} \mathrm{C}$ for $23 \mathrm{~h}$. Before the cooling down the reaction mixture, the J-Young tube was quickly brought into the glovebox. And then the reaction mixture was immediately transferred to a vial. Leaving the reaction mixture at room temperature furnished yellow crystals of $7(\mathbf{t h f})_{2}(307 \mathrm{mg}, 0.44 \mathrm{mmol}, 44 \%) .{ }^{1} \mathrm{H}$ NMR $(500 \mathrm{MHz}$, $\left.\mathrm{C}_{6} \mathrm{D}_{6}\right) \delta 1.03\left(\mathrm{~s}, 12 \mathrm{H}\right.$, pin- $\left.\mathrm{CH}_{3}\right), 1.33(\mathrm{~m}, 12 \mathrm{H}, \mathrm{THF}), 2.28\left(\mathrm{~s}, 6 \mathrm{H}, p-\mathrm{CH}_{3}\right), 2.48\left(\mathrm{~s}, 12 \mathrm{H}, o-\mathrm{CH}_{3}\right), 3.35(\mathrm{~m}, 12 \mathrm{H}$, THF), 6.90 (s, 4H, ArH of Mes), 7.04 (t, $J=7 \mathrm{~Hz}, 1 \mathrm{H}, \mathrm{ArH}), 7.31$ (t, $J=7 \mathrm{~Hz}, 2 \mathrm{H}, \operatorname{ArH}), 8.14$ (d, $J=8 \mathrm{~Hz}, 2 \mathrm{H}$, ArH); ${ }^{7} \mathrm{Li}$ NMR (194MHz, $\left.\mathrm{C}_{6} \mathrm{D}_{6}\right) \delta 0.59$ (s); ${ }^{11} \mathrm{~B}$ NMR (161 MHz, $\left.\mathrm{C}_{6} \mathrm{D}_{6}\right) \delta 14$ (br s), 27 (br s); ${ }^{13} \mathrm{C}$ NMR $(126$ $\left.\mathrm{MHz}, \mathrm{THF} d_{8}\right) \delta 21.0\left(\mathrm{CH}_{3}\right), 25.0\left(\mathrm{CH}_{3}\right), 25.12\left(\mathrm{CH}_{3}\right), 26.2\left(\mathrm{CH}_{2}\right.$ of THF $), 68.0\left(\mathrm{CH}_{2}\right.$ of THF $), 84.0\left(4^{\circ}\right), 111.3\left(4^{\circ}\right.$, bonding to the B nucleus), $127.1(\mathrm{CH}), 127.7(\mathrm{CH}), 128.5(\mathrm{CH}), 132.6\left(4^{\circ}\right), 141.6\left(4^{\circ}\right), 144.3\left(4^{\circ}\right), 145.3\left(4^{\circ}\right.$, bonding to the $\mathrm{B}$ nucleus), the allenic carbon of borataallene moiety was not observed; IR (ATR) $1350 \mathrm{~cm}^{-1}$ (merged $\mathrm{B}-\mathrm{C}=\mathrm{C}$ and aromatic $\mathrm{C}-\mathrm{H}$, see also S119 for DFT-based vibrational analysis); mp 107-110 ${ }^{\circ} \mathrm{C}$; Anal. Calcd for $\mathrm{C}_{44} \mathrm{H}_{63} \mathrm{~B}_{2} \mathrm{LiO}_{5}$ : C, 75.44; H, 9.06; Found: C, 75.29; H, 9.30.

\section{NMR yield of 7 (thf)}

The procedure for isolation was used and the crude mixture was dissolved in $\mathrm{C}_{6} \mathrm{D}_{6}$ to estimate NMR yield. Reaction condition: THF (1.00 mL), 1 (75.4 mg, $0.201 \mathrm{mmol})$, lithium phenylacetylide $(24.1 \mathrm{mg}, 0.223 \mathrm{mmol})$, $70{ }^{\circ} \mathrm{C}, 10 \mathrm{~h}$, trimethoxybenzene $(33.6 \mathrm{mg}, 0.200 \mathrm{mmol})$, crude $(129.5 \mathrm{mg})$; NMR yield: 7(thf) $295 \%$; See Figure S87 for NMR spectrum of the crude product.

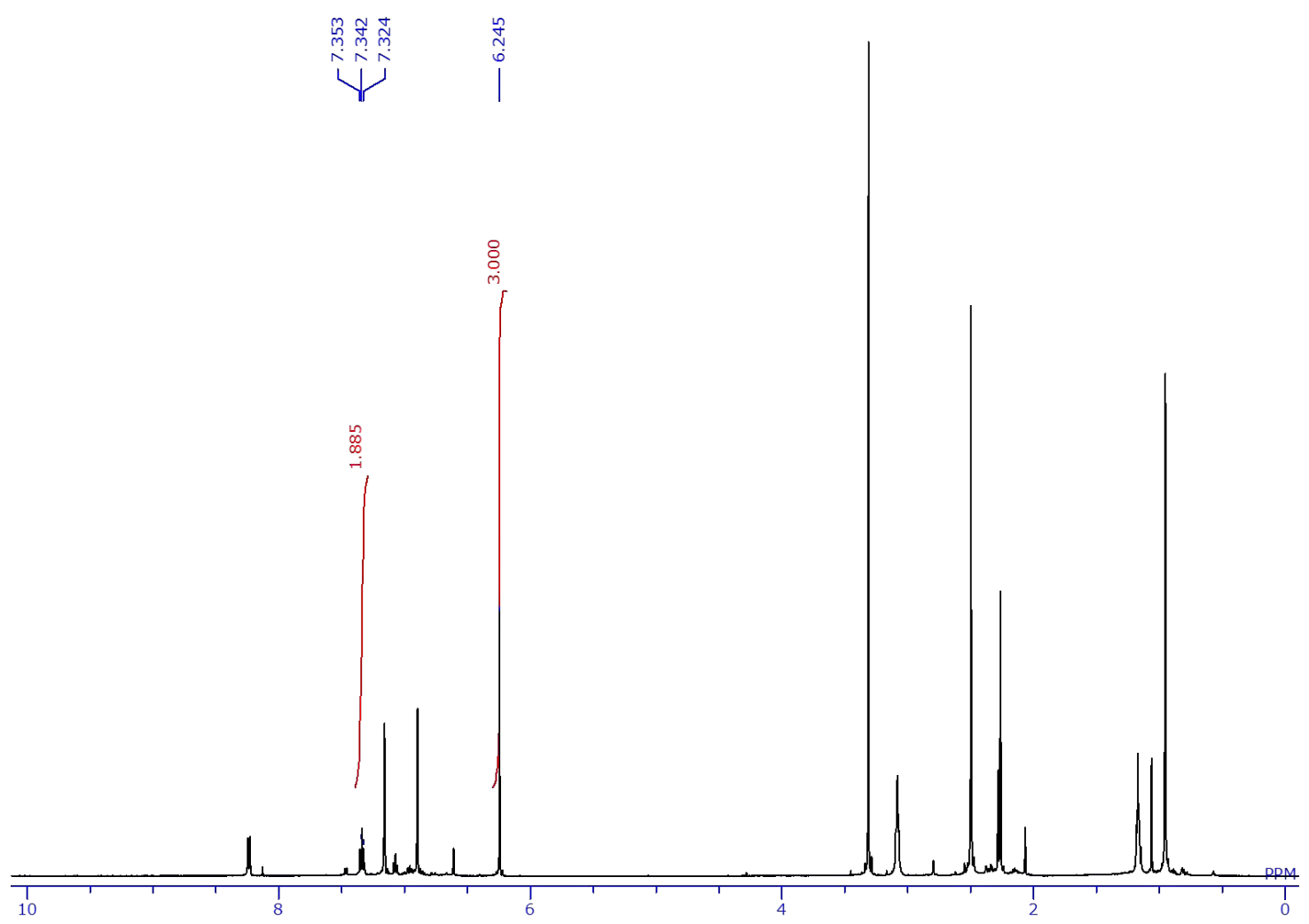

Figure S87. The ${ }^{1} \mathrm{H}$ NMR spectrum of the reaction mixture for the synthesis of $\mathbf{7}(\mathbf{t h f})_{2}\left(7.34 \mathrm{ppm}: \mathbf{7}(\mathbf{t h f})_{2} ; 6.25\right.$ ppm: internal standard, 1,3,5-trimethoxybenzene) 


\section{Reaction of 7(thf $)_{2}$ with $\mathrm{Et}_{3} \mathrm{~N} \cdot \mathrm{HCl}$ and NMR yield of $2 \mathrm{~b}$ and $2 \mathrm{c}$ (Scheme 6)}

In a glovebox, to a THF solution $(500 \mu \mathrm{L})$ of $1(75.2 \mathrm{mg}, 0.200 \mathrm{mmol})$ in a $10 \mathrm{~mL}$ J-young tube, a THF solution $(750 \mu \mathrm{L})$ of lithium phenylacetylide $(23.8 \mathrm{mg}, 0.220 \mathrm{mmol})$ was added at room temperature. After stirring the reaction mixture at $70{ }^{\circ} \mathrm{C}$ for $25 \mathrm{~h}, \mathrm{Et}_{3} \mathrm{~N} \cdot \mathrm{HCl}(30.3 \mathrm{mg}, 0.200 \mathrm{mmol})$ was added at room temperature. After stirring the reaction mixture at room temperature for $1 \mathrm{~h}$, volatiles were removed from the mixture in vacuo.

\section{NMR yield of $2 b$ and $2 c$}

THF (1.25 mL), 1 (75.2 mg, $0.200 \mathrm{mmol})$, lithium phenylacetylide (23.8 $\mathrm{mg}, 0.220 \mathrm{mmol}), \mathrm{Et}{ }_{3} \mathrm{~N} \cdot \mathrm{HCl}(30.3 \mathrm{mg}$, $0.200 \mathrm{mmol})$, trimethoxybenzene (16.8 mg, $0.200 \mathrm{mmol})$, crude (123.1 mg); NMR yield: 2b: 19\%, 2c: 80\%; See Figure S88 for NMR spectrum of the crude product.
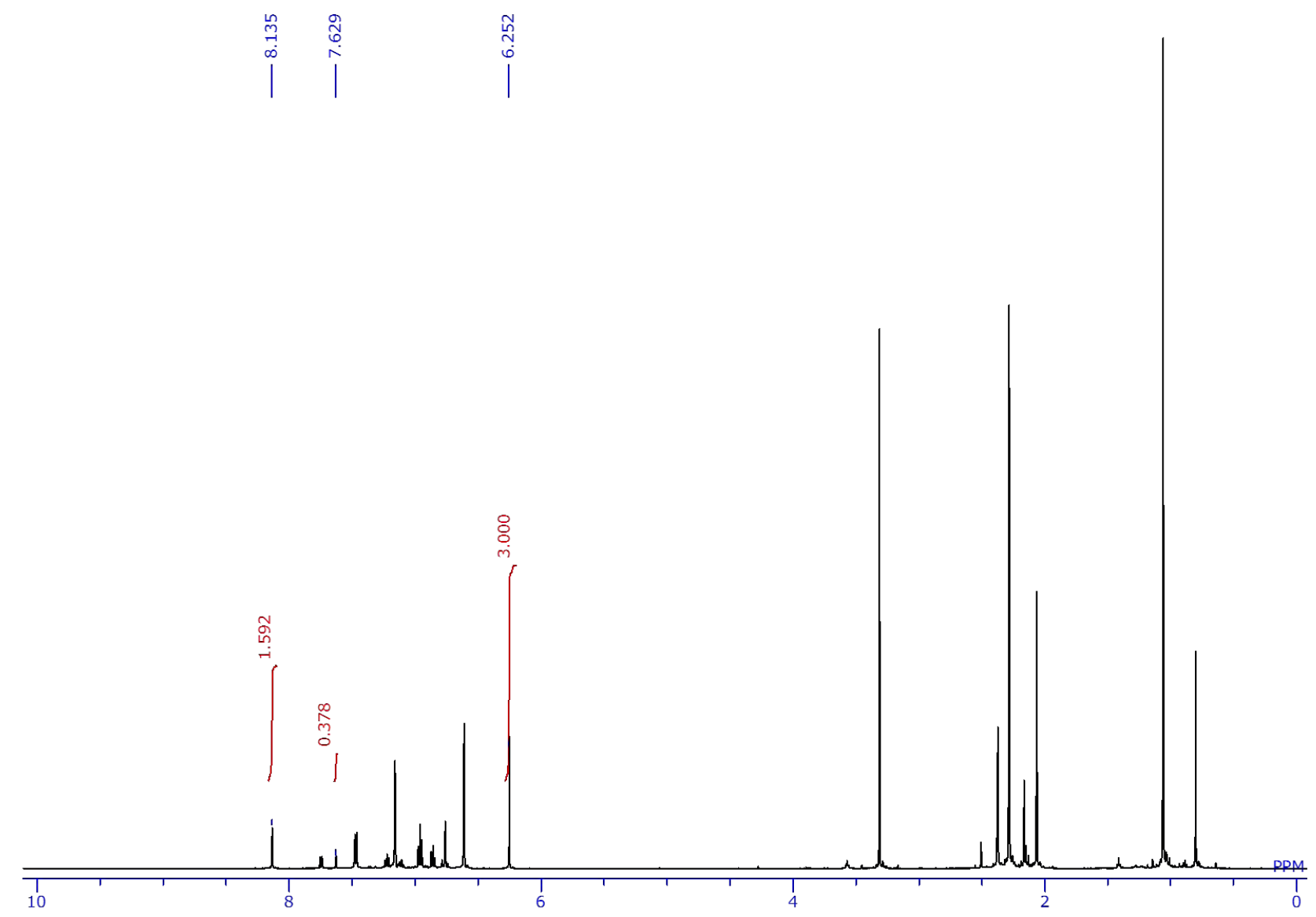

Figure S88. The ${ }^{1} \mathrm{H}$ NMR spectrum of the reaction mixture for the reaction of $\left.\mathbf{7 ( t h f}\right)_{2}$ with $\mathrm{Et}_{3} \mathrm{~N} \cdot \mathrm{HCl}(7.63 \mathrm{ppm}$ : 2b; 8.14 ppm: 2c; 6.25 ppm: internal standard, 1,3,5-trimethoxybenzene) 


\section{Reaction of 7(thf $)_{2}$ with MeI}

In a glovebox, to a THF solution $(2.50 \mathrm{~mL})$ of $1(376 \mathrm{mg}, 1.00 \mathrm{mmol})$ in a $10 \mathrm{~mL}$ J-young tube, a THF solution $(2.50 \mathrm{~mL})$ of lithium phenylacetylide $(118 \mathrm{mg}, 1.10 \mathrm{mmol})$ was added at room temperature. After stirring the reaction mixture at $70{ }^{\circ} \mathrm{C}$ for $23 \mathrm{~h}$, iodomethane $(93.4 \mu \mathrm{L}, 1.5 \mathrm{mmol})$ was added. After stirring the reaction mixture at $80{ }^{\circ} \mathrm{C}$ for $20 \mathrm{~h}$, volatiles were removed from the mixture in vacuo. The resulting residue was triturated with hexane. The resulting suspension was filtered through a pad of Celite. After the removal of volatiles from the filtrate, the resulting solid was recrystallized with THF to afford colorless crystals of $\mathbf{5 c}(140 \mathrm{mg}, 0.284 \mathrm{mmol}$, 28\%). ${ }^{1} \mathrm{H}$ NMR (500 MHz, $\mathrm{C}_{6} \mathrm{D}_{6}$ ) $\delta 1.04$ (s, 12H, pin- $\mathrm{CH}_{3}$ ), 2.07 (s. 6H, $p-\mathrm{CH}_{3}$ ), 2.27 (s, 12H, o- $\mathrm{CH}_{3}$ ), 2.43 (s, 3H, $\mathrm{CH}_{3}$ ), 6.59 (s, 4H, ArH of Mes), 6.81 (t, $\left.J=7 \mathrm{~Hz}, 1 \mathrm{H}, \mathrm{ArH}\right), 6.90$ (t, $\left.J=7 \mathrm{~Hz}, 2 \mathrm{H}, \operatorname{ArH}\right), 7.27$ (d, J = 8 Hz, 2H, ArH); ${ }^{11} \mathrm{~B}$ NMR (161 MHz, $\left.\mathrm{C}_{6} \mathrm{D}_{6}\right) \delta 30$ (br s), 75 (br s); ${ }^{13} \mathrm{C}$ NMR (126 MHz, $\left.\mathrm{C}_{6} \mathrm{D}_{6}\right) \delta 21.2\left(\mathrm{CH}_{3}\right), 22.9\left(\mathrm{CH}_{3}\right)$, $23.4\left(\mathrm{CH}_{3}\right), 24.8\left(\mathrm{CH}_{3}\right), 83.4\left(4^{\circ}\right), 126.0(\mathrm{CH}), 127.1(\mathrm{CH}), 128.1(\mathrm{CH}), 128.8(\mathrm{CH}), 138.5(4), 140.2(4), 143.5$ (br, $4^{\circ}$, bonding to the B nucleus), 144.1 (4), 147.1 (br, $4^{\circ}$, bonding to the B nucleus), 158.3 (br, $4^{\circ}$, bonding to the B nucleus); mp 136-138 ${ }^{\circ} \mathrm{C}$; HRMS (ESI+) Calcd for $\mathrm{C}_{33} \mathrm{H}_{42} \mathrm{~B}_{2} \mathrm{O}_{2}: 492.3371$, found: 492.3374.

THF (1.25 mL), 1 (75.4 mg, $0.201 \mathrm{mmol})$, lithium phenylacetylide (24.1 mg, $0.223 \mathrm{mmol})$, iodomethane ( $37.5 \mu \mathrm{L}$, $0.600 \mathrm{mmol}$ ), trimethoxybenzene (33.6 mg, $0.200 \mathrm{mmol})$, crude (148 mg); NMR yield: $\mathbf{5 c}$ : $96 \%$. See Figure S89 for NMR spectrum of the crude product.
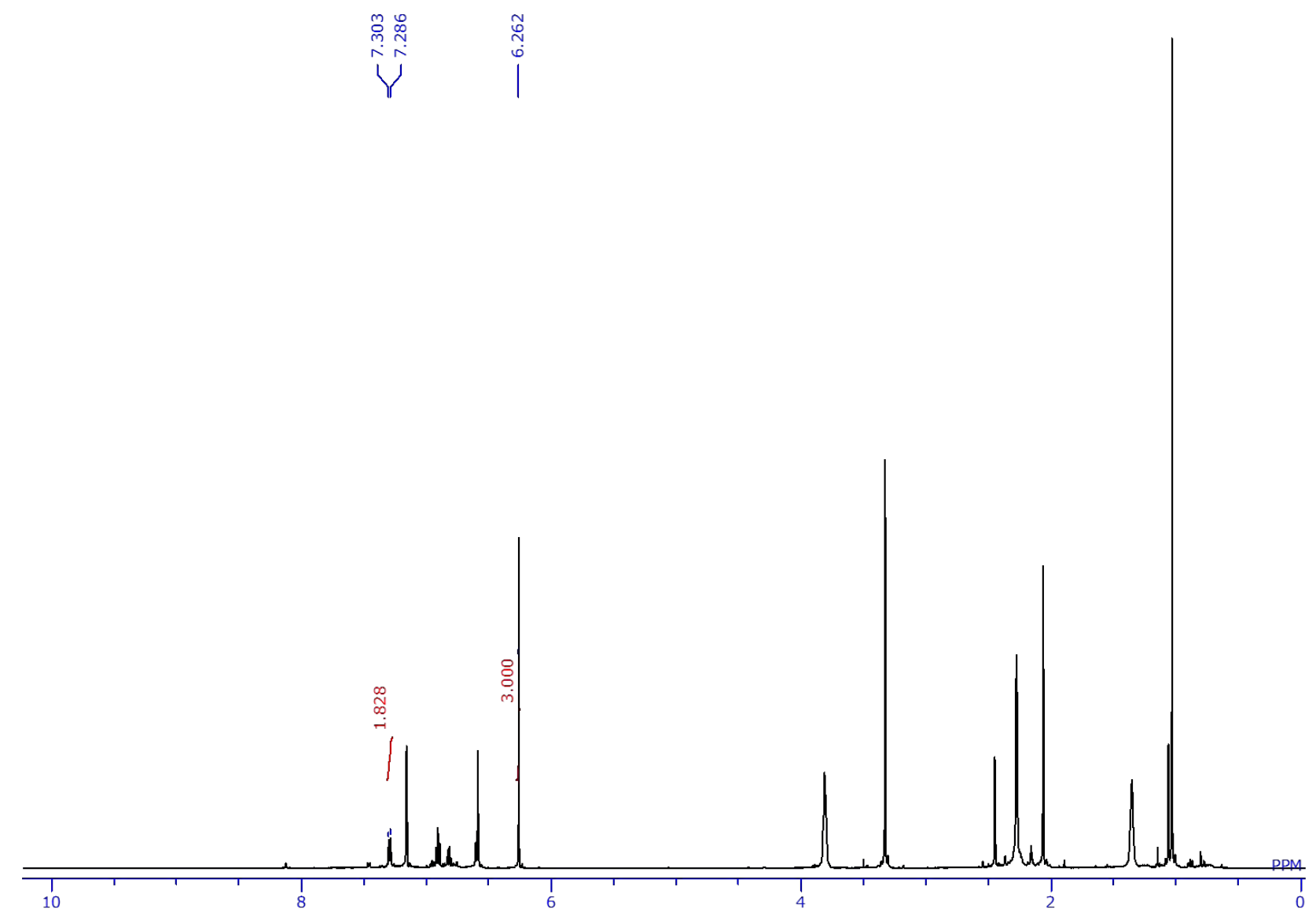

Figure S89. The ${ }^{1} \mathrm{H}$ NMR spectrum of the reaction mixture for the synthesis of $\mathbf{5 c}(7.31 \mathrm{ppm}$ : 5c; $6.26 \mathrm{ppm}$ : internal standard, 1,3,5-trimethoxybenzene) 


\section{Reaction of 1 with 1-ethynylquinoline (Scheme 8)}

In a glovebox, to a toluene solution $(3.85 \mathrm{~mL})$ of $\mathbf{1}(1.45 \mathrm{~g}, 3.85 \mathrm{mmol})$ in a $10 \mathrm{~mL}$ J-young tube. 1-ethynylquinoline (593 mg, $3.85 \mathrm{mmol}$ ) was added. After stirring the reaction mixture at $100{ }^{\circ} \mathrm{C}$ for 5 days, volatiles were removed from the reaction mixture in vacuo. Filtration of the residue by cold toluene gave yellow solid of an isomeric mixture of $9 \mathbf{a}$ and $9 \mathbf{d}(857 \mathrm{mg}, 1.62 \mathrm{mmol}, 42 \%, 9 \mathbf{a}: 9 \mathbf{d}=46: 54)$. The obtained mixture was directly used for the subsequent reaction.

\section{Reaction of an isomeric mixture of 9a and 9d with (4-bromophenyl)diphenylamine (Scheme 8)}

In a glovebox, a diboxane solution $(3 \mathrm{~mL}$ ) of an isomeric mixture of 9a and 9d (264 $\mathrm{mg}, 0.500 \mathrm{mmol}$ ), (4-bromophenyl)diphenylamine $(178 \mathrm{mg}, 0.55 \mathrm{mmol})$ and X-Phos Pd G2 $(8.00 \mathrm{mg}, 10.0 \mu \mathrm{mol})$ in a $10 \mathrm{~mL}$ J-young tube. Then, degassed $0.5 \mathrm{M}$ aqueous $\mathrm{K}_{3} \mathrm{PO}_{4}$ solution $(7 \mathrm{~mL})$ was added and the reaction mixture was stirred at $80{ }^{\circ} \mathrm{C}$ for $21 \mathrm{~h}$. Diethyl ether $(10 \mathrm{~mL})$ and water $(10 \mathrm{~mL})$ were added to the mixture, and the aqueous phase was extracted with diethyl ether $(3 \cdot 10 \mathrm{~mL})$. The organic phase was dried over $\mathrm{MgSO}_{4}$, concentrated in vacuo. The resulting residue filtrated by $\mathrm{CH}_{2} \mathrm{Cl}_{2} /$ hexane $(7: 3, \mathrm{v} / \mathrm{v})$ through a pad of silica-gel. After volatiles were removed from the reaction mixture in vacuo, purification of the residue by GPC ( 6 cycles) afforded red oils of 11a (120 mg, $0.186 \mathrm{mmol}, 37 \%)$ and $11 \mathrm{~d}(71.3 \mathrm{mg}, 0.110 \mathrm{mmol}, 22 \%)$. These oils were solved in hexane with ultrasonic generator and get the yellow powder of 11a or the orange powder of 11d. Single crystals of 11a suitable for X-ray diffraction analysis were obtained by slow evaporation of its benzene solution at room temperature. By leaving the benzene solution of $\mathbf{1 1 d}$ at room temperature, only crystals of $\mathbf{1 1 a}$ were obtained probably due to photo-isomerization from 11d to 11a by visible light. Therefore, we have no crystal structure of 11d. 11a: ${ }^{1} \mathrm{H}$ NMR (400 MHz, THF-d $\left.d_{8}\right) \delta 2.02$ (s, 12H, $\left.p-\mathrm{CH}_{3}\right), 2.06$ (s, $\left.6 \mathrm{H}, o-\mathrm{CH}_{3}\right), 6.48$ (s, 4H, ArH of Mes), 6.66 (d, $J=8$ $\mathrm{Hz}, 2 \mathrm{H}, \mathrm{ArH}), 6.90-7.00$ (m, 8H, ArH), 7.19 (t, $J=8 \mathrm{~Hz}, 4 \mathrm{H}, \mathrm{ArH}), 7.30$ (s, 6H, benzene) 7.43 (s, 1H, CH), 7.56 (m, 1H, ArH of quinoline), $7.75(\mathrm{~m}, 1 \mathrm{H}, \mathrm{ArH}$ of quinoline), 8.11 (m, 1H, ArH of quinoline), 8.44 (m, 1H, ArH of quinoline), 8.99 (m, 1H, ArH of quinoline); ${ }^{11} \mathrm{~B}$ NMR $\left(128 \mathrm{MHz}, \mathrm{THF}-d_{8}\right) \delta \quad \bullet(\mathrm{br} \mathrm{s}) ;{ }^{13} \mathrm{C} \mathrm{NMR}(101 \mathrm{MHz}$, THF- $\left.d_{8}\right) \delta 20.7\left(\mathrm{CH}_{3}\right), 25.5\left(\mathrm{CH}_{3}\right), 122.0(\mathrm{CH}), 122.7(\mathrm{CH}), 122.9(\mathrm{CH}), 123.7(\mathrm{CH}), 123.8(\mathrm{CH}), 124.4(\mathrm{CH})$, $128.8\left(\mathrm{CH}\right.$ and $\left.4^{\circ}\right), 129.1\left(4^{\circ}\right), 129.6(\mathrm{CH}), 130.3(\mathrm{CH}), 130.4(\mathrm{CH}), 130.7(\mathrm{CH}), 133.9\left(\mathrm{CH}\right.$ and $\left.4^{\circ}\right), 135.6\left(4^{\circ}\right)$, 139.6 (CH), $142.4\left(4^{\circ}\right), 145.2(\mathrm{CH}), 145.8\left(4^{\circ}\right), 146.2\left(4^{\circ}\right), 147.3\left(\mathrm{br}, 4^{\circ}\right.$, bonding to the B nucleus), $145.7\left(4^{\circ}\right)$, 154.6 (br, $4^{\circ}$, bonding to the B nucleus); $\mathrm{mp} 222-224{ }^{\circ} \mathrm{C}$ (decomp.), Absorption and emission spectra can be found the following pages, HRMS (ESI+) Calcd for $\mathrm{C}_{47} \mathrm{H}_{43} \mathrm{BN}_{2}: 664.3519$, found: 664.3495. 11d: ${ }^{1} \mathrm{H}$ NMR (400 MHz, THF- $\left.d_{8}\right) \delta 1.97\left(\mathrm{~s}, 12 \mathrm{H}, p-\mathrm{CH}_{3}\right), 2.11\left(\mathrm{~s}, 6 \mathrm{H}, o-\mathrm{CH}_{3}\right), 6.57$ (s, 4H, ArH of Mes), 6.77 (s, 1H, CH), 6.99 (m, $J=8$ $\mathrm{Hz}, 4 \mathrm{H}, \mathrm{ArH}), 7.08$ (d, $J=9 \mathrm{~Hz}, 4 \mathrm{H}, \mathrm{ArH}), 7.19$ (m, 6H, ArH), 7.54 (m, 1H, ArH of quinoline), 7.59 (m, 1H, ArH of quinoline), $7.74(\mathrm{~m}, 1 \mathrm{H}, \mathrm{ArH}$ of quinoline), $7.95(\mathrm{~m}, 1 \mathrm{H}, \mathrm{ArH}$ of quinoline), 8.51 (m, 1H, ArH of quinoline), 8.97 (m, 1H, ArH of quinoline); ${ }^{11} \mathrm{~B}$ NMR $\left(128 \mathrm{MHz}, \mathrm{THF}-d_{8}\right) \delta 5(\mathrm{br} \mathrm{s}) ;{ }^{13} \mathrm{C}$ NMR $\left(101 \mathrm{MHz}, \mathrm{THF}-d_{8}\right) \delta 20.7$ $\left(\mathrm{CH}_{3}\right), 25.7\left(\mathrm{CH}_{3}\right), 123.1(\mathrm{CH}), 123.2(\mathrm{CH}), 124.1(\mathrm{CH}), 124.6(\mathrm{CH}), 124.9(\mathrm{CH}), 127.1(\mathrm{CH}), 129.4\left(4^{\circ}\right), 129.5$ $(\mathrm{CH}), 129.79(\mathrm{CH}), 129.88(\mathrm{CH}), 130.4(\mathrm{CH}), 133.5\left(4^{\circ}\right), 134.0(\mathrm{CH}), 136.6\left(4^{\circ}\right), 139.9(\mathrm{CH}), 140.1\left(4^{\circ}\right), 142.2$ $\left(4^{\circ}\right), 146.3(\mathrm{CH}), 147.0\left(4^{\circ}\right), 147.8\left(4^{\circ}\right), 148.7(\mathrm{CH}), 150.3$ (br, $4^{\circ}$, bonding to the B nucleus), $152.0\left(\mathrm{br}, 4^{\circ}\right.$, bonding to the $\mathrm{B}$ nucleus); mp 220-220 ${ }^{\circ} \mathrm{C}$ (decomp.); HRMS (ESI+) Calcd for $\mathrm{C}_{47} \mathrm{H}_{43} \mathrm{BN}_{2}: 646.3519$, found: 646.3543 


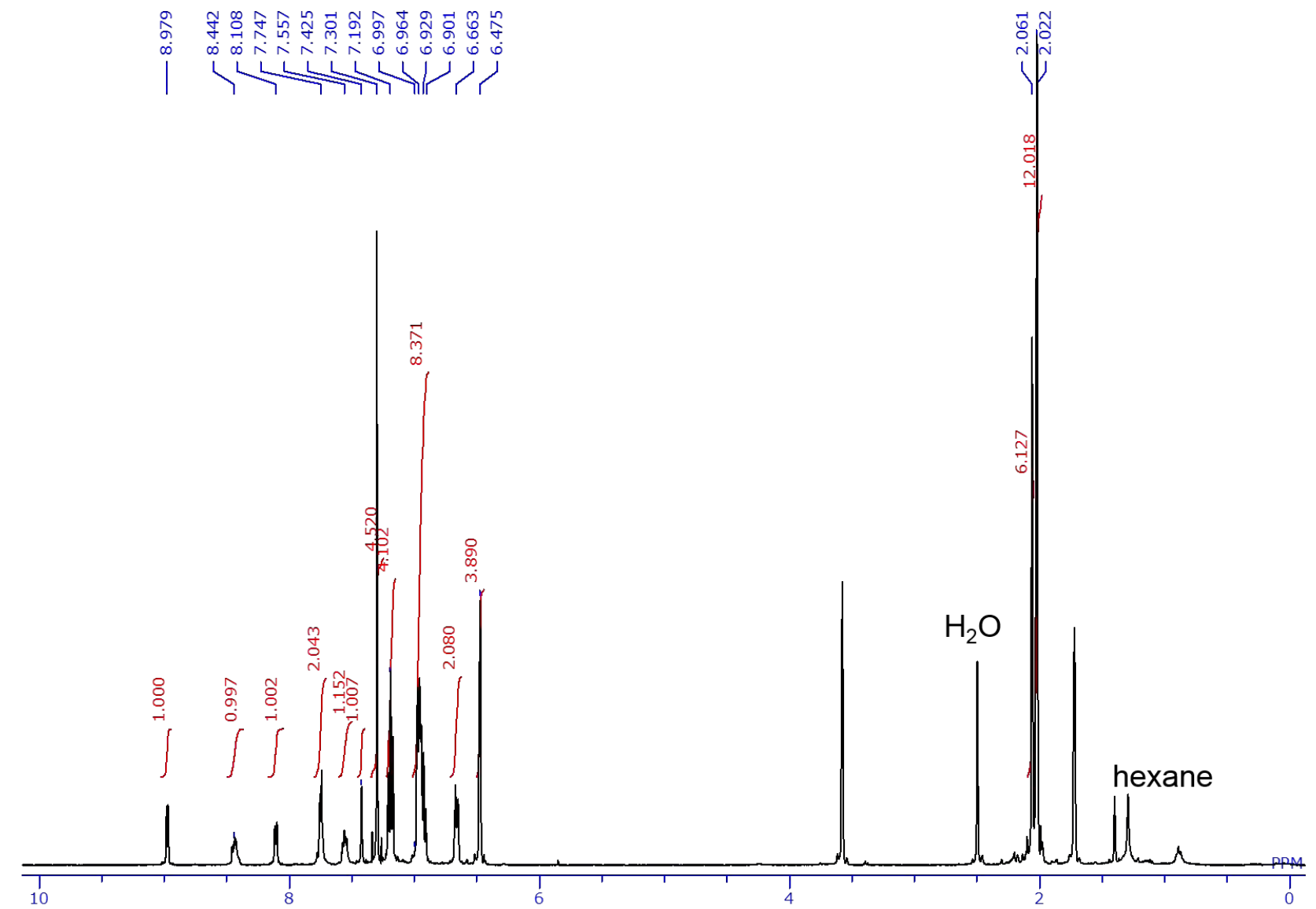

Figure S90. The ${ }^{1} \mathrm{H}$ NMR spectrum $\left(\mathrm{THF}-d_{8}\right)$ of 11a

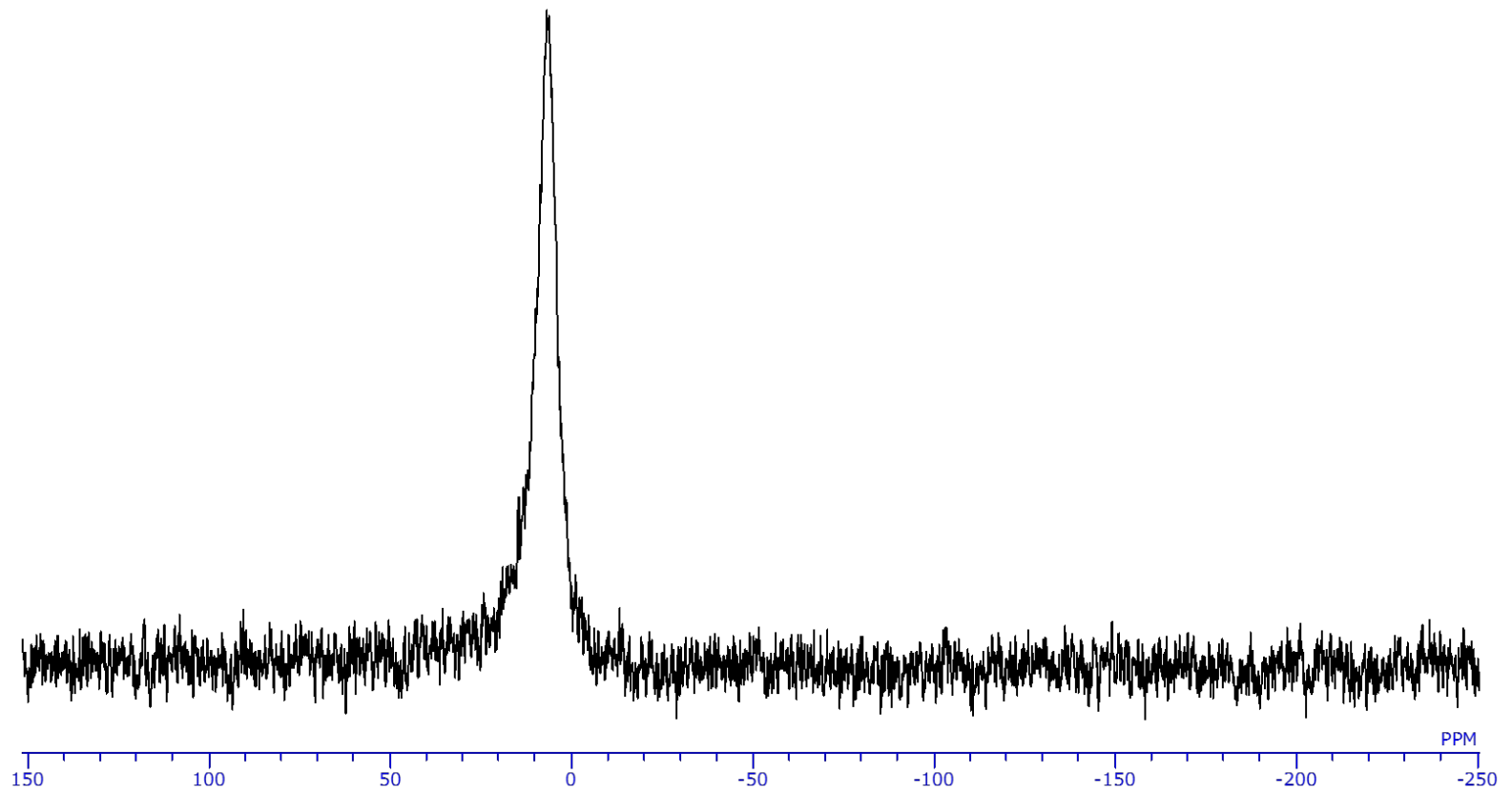

Figure S91. The ${ }^{11}$ B NMR spectrum $\left(\right.$ THF- $\left.d_{8}\right)$ of 11a 


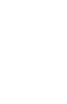

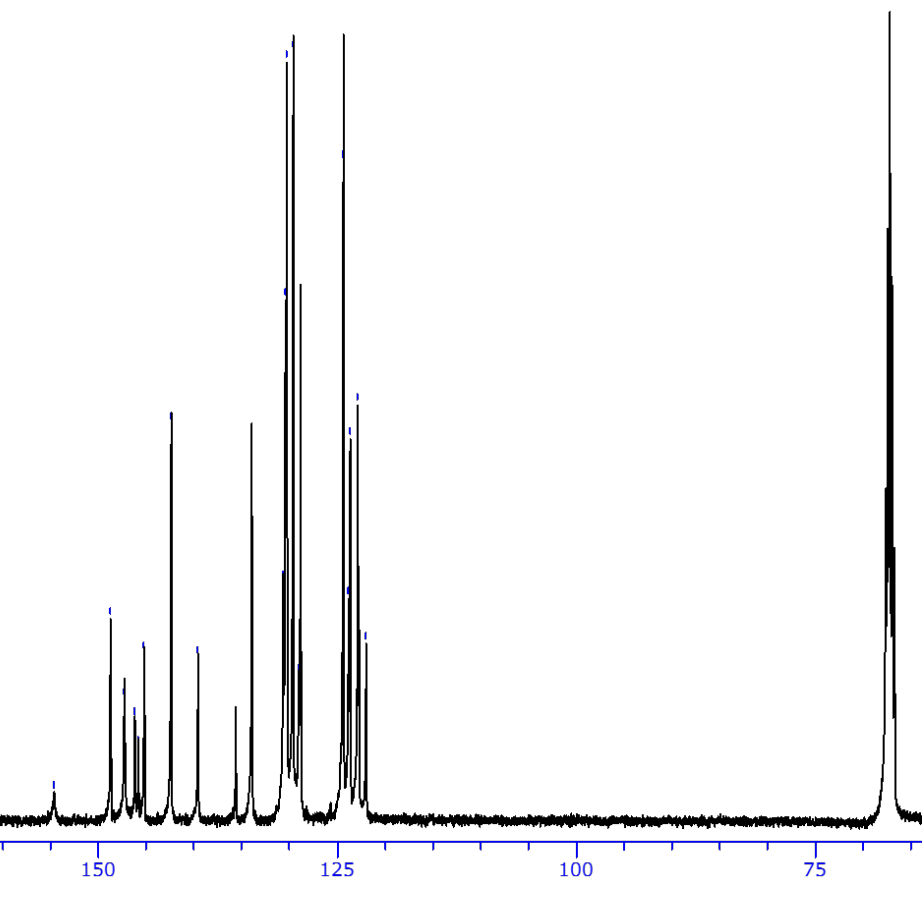

Figure S92. The ${ }^{13} \mathrm{C}$ NMR spectrum $\left(\mathrm{THF}-d_{8}\right)$ of 11a

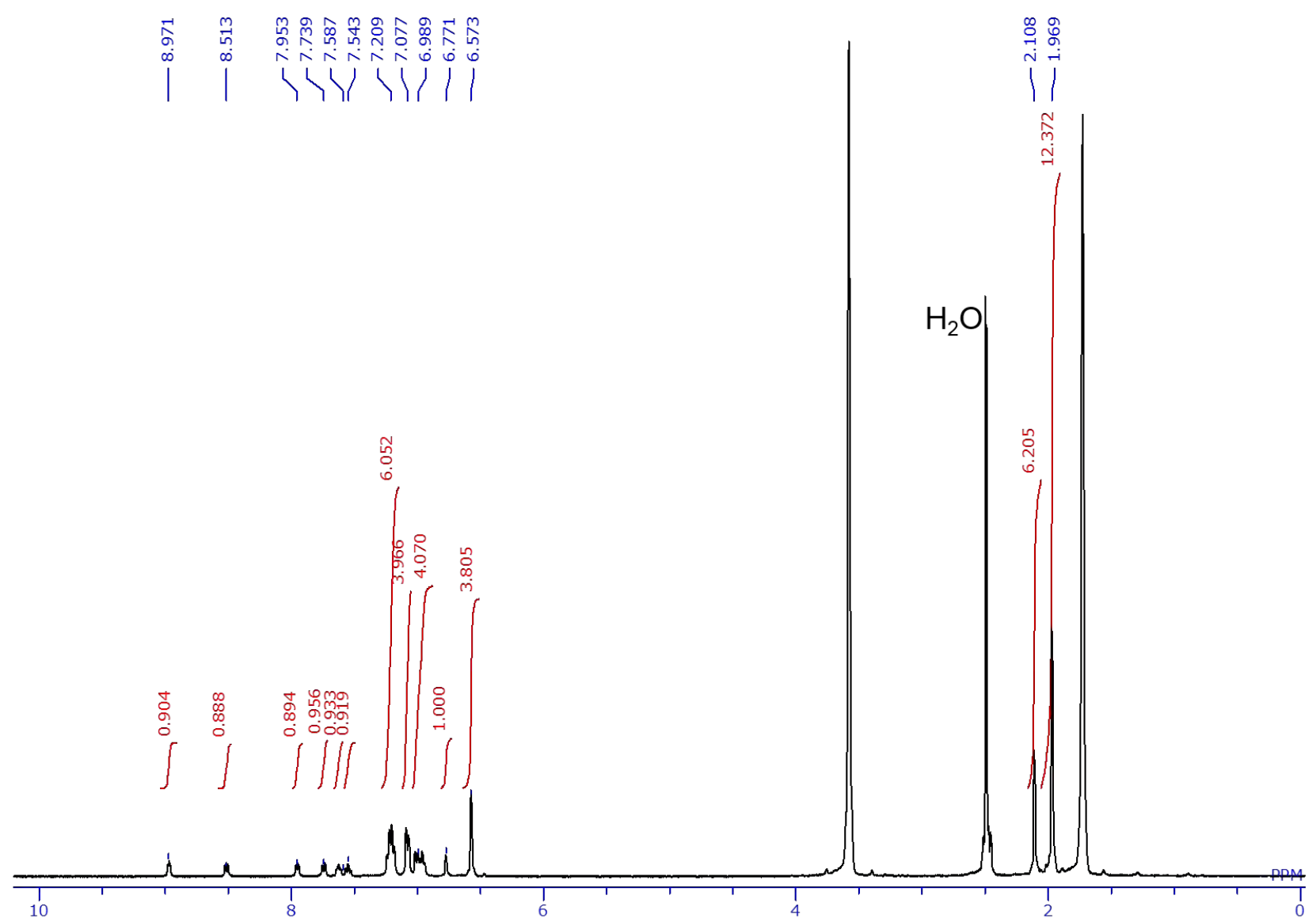

Figure S93. The ${ }^{1} \mathrm{H}$ NMR spectrum $\left(\mathrm{THF}-d_{8}\right)$ of $\mathbf{1 1 d}$ 


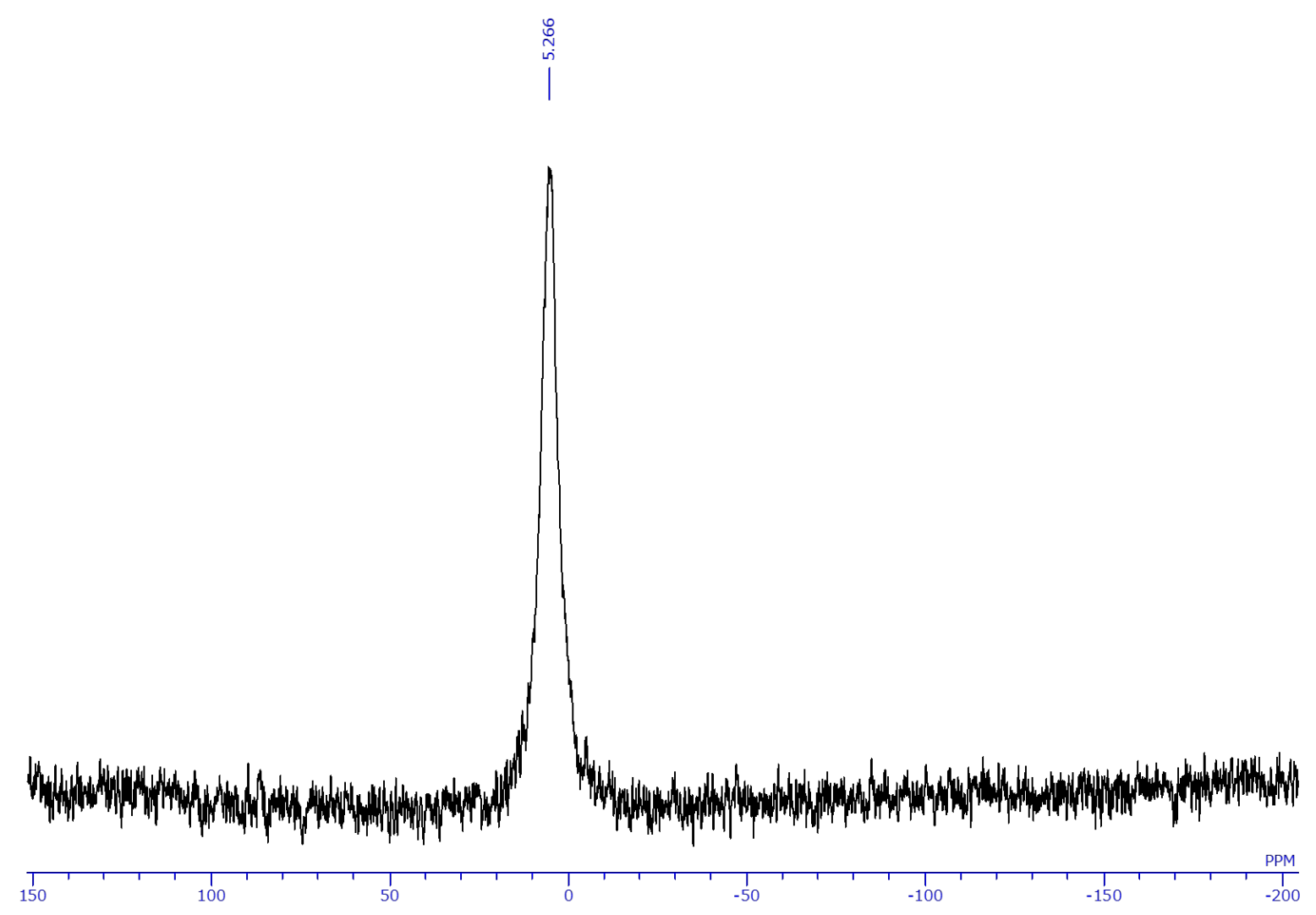

Figure S94. The ${ }^{11}$ B NMR spectrum (THF- $\left.d_{8}\right)$ of 11d

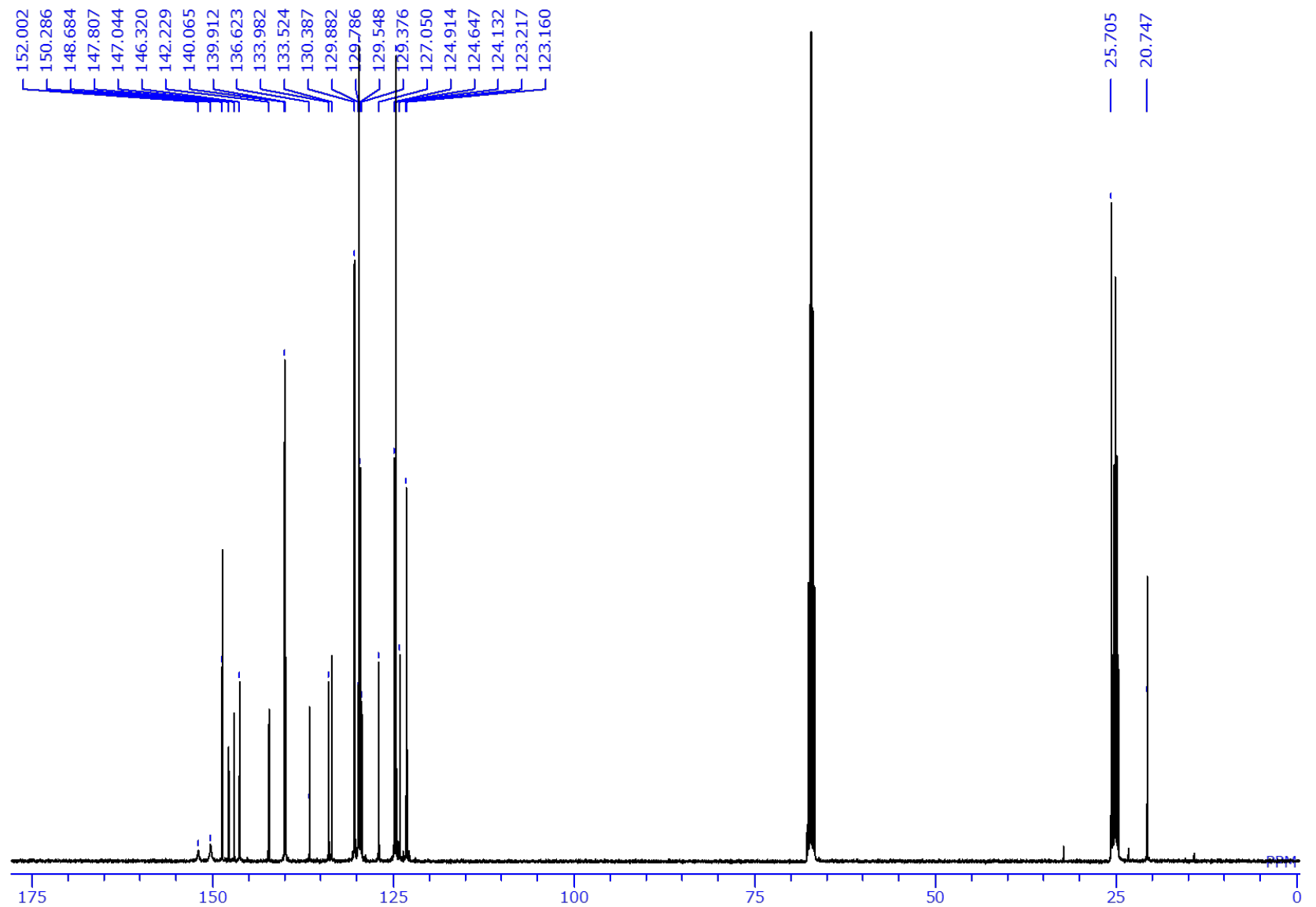

Figure S95. The ${ }^{13} \mathrm{C}$ NMR spectrum $\left(\mathrm{THF}-d_{8}\right)$ of $\mathbf{1 1 d}$ 


\section{Photophysical study on 11a and 11d}

UV-vis absorption and fluorescent spectra of 11a and 11d were measured with a UV-3600 (Shimadzu) spectrometer and FP-8200 (JASCO) using $120 \mu \mathrm{M}$ sample solutions in a $1 \mathrm{~cm}$ square quartz cell. Sample preparation: The powder of 11a $(3.23 \mathrm{mg}, 4.99 \mu \mathrm{mol})$ was dissolved in toluene $(5.00 \mathrm{~mL})$. An aliquot (1.00 mL) of the resulting solution was diluted to $10 \mathrm{~mL}$ with toluene in a volumetric flask to form a $100 \mu \mathrm{M}$ solution. The powder of $11 \mathrm{~d}(2.07 \mathrm{mg}, 3.20 \mu \mathrm{mol})$ was dissolved in toluene and the resulting solution was diluted up to $25 \mathrm{~mL}$ with a volumetric flask to form a $128 \mu \mathrm{M}$ solution Quantum yields were measured by using C9920-03G and were recorded as an average from five runs (Hamamatsu). Lifetime measurement was performed by using Quantaurus-Tau: C11367-11 (Hamamatsu) and the obtained lifetimes were recorded as an average from two runs.

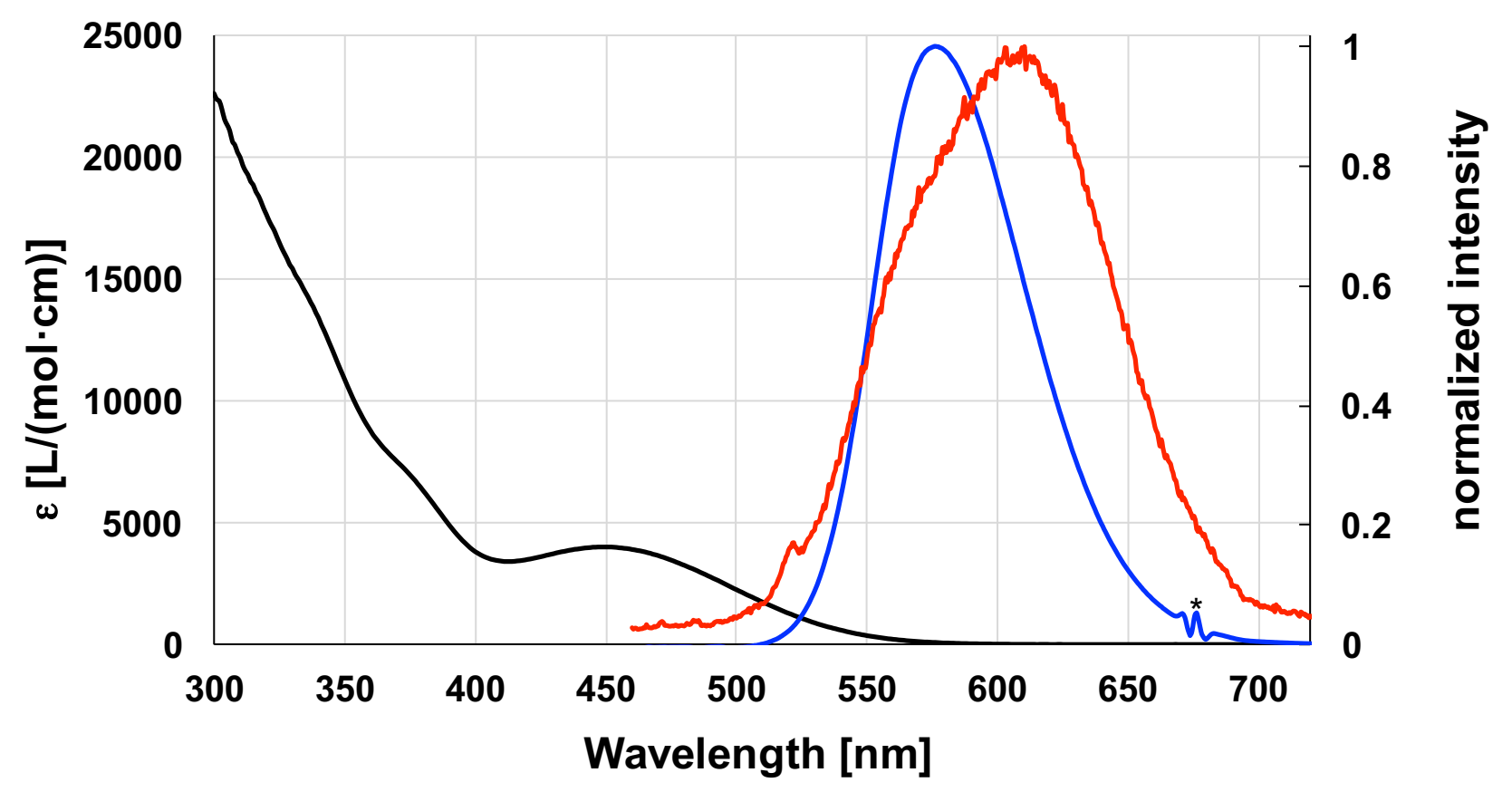

Figure S96. UV-vis absorption (black, toluene solution) and emission spectra of 11d [excited at $450 \mathrm{~nm}$; blue: from powder, red: from toluene solution] (asterisk showed an artifact from the sample holder) 


\section{Details for X-ray diffraction analysis}

Details of the crystal data and a summary of the intensity data collection parameters are listed in Table S1. In each case a suitable crystal was mounted with mineral oil (Aldrich) or perfluoropolyalkylether (viscosity $80 \mathrm{cSt}$., abcr $\mathrm{GmbH}$ ) to the glass fiber and transferred to the goniometer of Rigaku VariMax Saturn CCD diffractometer with graphite-monochromated MoK $\alpha$ radiation $(\lambda=0.71075 \AA)$. All the following procedure for analysis, Yadokari-XG 2009 was used as a graphical interface. ${ }^{3}$ The structures were solved by direct methods with (SIR-2014) ${ }^{4}$ and refined by full-matrix least-squares techniques against $F^{2}$ (SHELXL-2014). ${ }^{5}$ The intensities were corrected for Lorentz and polarization effects. The non-hydrogen atoms were refined anisotropically. Hydrogen atoms were placed using AFIX instructions. All the obtained crystal structures are shown in Figures S97-S117.

Table S1. Crystallographic data and structure refinement details for $2 \mathbf{2 a}, 2 \mathbf{b}, 2 \mathbf{c}, 3 \mathrm{Aa}, 3 \mathrm{Ac}, 3 \mathrm{Ba}, 3 \mathrm{Bc}, 3 \mathrm{Cb}, 3 \mathrm{Da}$,

3Dc, 3Ea, 3Ec, 3Fa, 3Ha, 3Hc, 4, 5a, 5c, 6(thf) 2 , 7(thf) 2 , and 11a

\begin{tabular}{|c|c|c|c|c|c|}
\hline & $2 a$ & $2 \mathbf{b}$ & $2 \mathrm{c}$ & 3Aa & 3Ac \\
\hline formula & $\mathrm{C}_{32} \mathrm{H}_{40} \mathrm{~B}_{2} \mathrm{O}_{2}$ & $\mathrm{C}_{32} \mathrm{H}_{40} \mathrm{~B}_{2} \mathrm{O}_{2}$ & $\mathrm{C}_{32} \mathrm{H}_{40} \mathrm{~B}_{2} \mathrm{O}_{2}$ & $\mathrm{C}_{32} \mathrm{H}_{39} \mathrm{~B}_{2} \mathrm{BrO}_{2}$ & $\mathrm{C}_{32} \mathrm{H}_{39} \mathrm{~B}_{2} \mathrm{BrO}_{2}$ \\
\hline fw & 478.26 & 478.26 & 478.26 & 557.16 & 557.16 \\
\hline $\mathrm{T}(\mathrm{K})$ & $93(2)$ & $93(2)$ & $93(2)$ & $93(2)$ & $93(2)$ \\
\hline$\lambda(\AA)$ & 0.71075 & 0.71075 & 0.71075 & 0.71075 & 0.71075 \\
\hline cryst syst & Monoclinic & Orthorhombic & Monoclinic & Monoclinic & Monoclinic \\
\hline space group & $P 2_{1} / n$ & $P 2_{1} 2_{1} 2_{1}$ & $P 2_{1} / n$ & $P 2_{1} / c$ & $P 2_{1} / c$ \\
\hline $\mathrm{a},(\AA)$ & $21.179(5)$ & $9.147(3)$ & $8.818(3)$ & $15.857(3)$ & $11.783(4)$ \\
\hline $\mathrm{b},(\AA)$ & $18.427(4)$ & $9.787(3)$ & $36.059(11)$ & $10.0220(16)$ & $15.689(5)$ \\
\hline $\mathrm{c},(\AA)$ & $14.466(3)$ & $31.937(10)$ & $8.850(3)$ & $19.656(4)$ & $15.773(5)$ \\
\hline$\alpha,(\operatorname{deg})$ & 90 & 90 & 90 & 90 & 90 \\
\hline$\beta,(\operatorname{deg})$ & $99.820(3)$ & 90 & $90.252(4)$ & $111.004(3)$ & $99.815(5)$ \\
\hline$\gamma,(\operatorname{deg})$ & 90 & 90 & 90 & 90 & 90 \\
\hline$V,\left(\AA^{3}\right)$ & $5563(2)$ & $2859.0(16)$ & $2814.2(14)$ & 2916.2(9) & $2873.5(16)$ \\
\hline Z & 8 & 4 & 4 & 4 & 4 \\
\hline $\mathrm{D}_{\text {calc }},\left(\mathrm{g} / \mathrm{cm}^{3}\right)$ & 1.142 & 1.111 & 1.129 & 1.269 & 1.288 \\
\hline$\mu\left(\mathrm{mm}^{-1}\right)$ & 0.068 & 0.066 & 0.067 & 1.436 & 1.458 \\
\hline $\mathrm{F}(000)$ & 2064 & 1032 & 1032 & 1168 & 1168 \\
\hline cryst size (mm) & $0.20 \times 0.20 \times 0.15$ & $0.20 \times 0.17 \times 0.05$ & $0.20 \times 0.15 \times 0.11$ & $0.20 \times 0.20 \times 0.15$ & $0.20 \times 0.20 \times 0.15$ \\
\hline $2 \theta$ range, $(\mathrm{deg})$ & $3.065-25.992$ & $3.048-25.998$ & $3.226-26.000$ & $3.002-27.478$ & $3.134-27.512$ \\
\hline reflns collected & 20294 & 19563 & 25593 & 23380 & 23265 \\
\hline indep reflns $/ R_{\text {int }}$ & $5458 / 0.0591$ & $5588 / 0.0520$ & $5511 / 0.0557$ & $6569 / 0.0503$ & $6545 / 0.0488$ \\
\hline Params & 339 & 335 & 335 & 344 & 344 \\
\hline GOF on $F^{2}$ & 1.103 & 1.117 & 1.143 & 1.107 & 1.007 \\
\hline$R_{1}, w R_{2}[I>2 \sigma(I)]$ & $0.0737,0.1704$ & $0.0749,0.1840$ & $0.0688,0.1603$ & $0.0560,0.1283$ & $0.0413,0.0904$ \\
\hline$R_{1}, w R_{2}$ (all data) & $0.0983,0.1894$ & $0.0880,0.1978$ & $0.0821,0.1703$ & $0.0712,0.1387$ & $0.0567,0.0985$ \\
\hline
\end{tabular}




\begin{tabular}{|c|c|c|c|c|c|}
\hline & $3 \mathbf{B a}$ & $3 B c$ & $3 \mathrm{Cb}$ & 3Da & 3Dc \\
\hline formula & $\mathrm{C}_{32} \mathrm{H}_{39} \mathrm{~B}_{2} \mathrm{BrO}_{2}$ & $\mathrm{C}_{32} \mathrm{H}_{39} \mathrm{~B}_{2} \mathrm{BrO}_{2}$ & $\mathrm{C}_{34} \mathrm{H}_{45} \mathrm{~B}_{2} \mathrm{NO}_{2}$ & $\mathrm{C}_{32} \mathrm{H}_{39} \mathrm{~B}_{2} \mathrm{FO}_{2}$ & $\mathrm{C}_{32} \mathrm{H}_{39} \mathrm{~B}_{2} \mathrm{FO}_{2}$ \\
\hline fw & 557.16 & 557.16 & 521.33 & 496.25 & 496.25 \\
\hline $\mathrm{T}(\mathrm{K})$ & $93(2)$ & $93(2)$ & $93(2)$ & $93(2)$ & $93(2)$ \\
\hline$\lambda(\AA)$ & 0.71075 & 0.71075 & 0.71075 & 0.71075 & 0.71075 \\
\hline cryst syst & Monoclinic & Monoclinic & Monoclinic & Monoclinic & Monoclinic \\
\hline space group & $C 2 / c$ & $P 2_{1} / c$ & $P$ n & $C 2 / c$ & $P 2_{1} / n$ \\
\hline a, $(\AA)$ & $23.103(3)$ & $11.801(2)$ & $9.667(3)$ & $21.448(4)$ & $8.705(3)$ \\
\hline $\mathrm{b},(\AA)$ & $16.332(2)$ & $15.554(3)$ & $11.589(4)$ & $18.667(4)$ & $35.874(12)$ \\
\hline c, $(\AA)$ & $15.614(2)$ & $16.698(3)$ & $14.115(4)$ & $14.378(3)$ & $9.064(3)$ \\
\hline$\alpha,(\mathrm{deg})$ & 90 & 90 & 90 & 90 & 90 \\
\hline$\beta,(\operatorname{deg})$ & $99.640(2)$ & $104.974(3)$ & $96.220(5)$ & $100.147(3)$ & $90.276(3)$ \\
\hline$\gamma,(\operatorname{deg})$ & 90 & 90 & 90 & 90 & 90 \\
\hline$V,\left(\AA^{3}\right)$ & $5808.3(12)$ & $2960.9(9)$ & $1572.1(8)$ & $5666.5(19)$ & $2830.7(16)$ \\
\hline Z & 8 & 4 & 2 & 8 & 4 \\
\hline$D_{\text {calc, }},\left(\mathrm{g} / \mathrm{cm}^{3}\right)$ & 1.274 & 1.250 & 1.101 & 1.163 & 1.164 \\
\hline$\mu\left(\mathrm{mm}^{-1}\right)$ & 1.442 & 1.415 & 0.066 & 0.074 & 0.074 \\
\hline $\mathrm{F}(000)$ & 2336 & 1168 & 564 & 2128 & 1064 \\
\hline cryst size (mm) & $0.20 \times 0.20 \times 0.15$ & $0.20 \times 0.20 \times 0.07$ & $0.20 \times 0.20 \times 0.17$ & $0.20 \times 0.20 \times 0.17$ & $0.20 \times 0.20 \times 0.08$ \\
\hline $2 \theta$ range, $(\mathrm{deg})$ & $3.052-27.480$ & $3.171-27.508$ & $3.004-27.474$ & $3.071-27.482$ & $3.195-27.553$ \\
\hline reflns collected & 23562 & 24044 & 12596 & 23176 & 28368 \\
\hline indep reflns $/ \mathrm{R}_{\text {int }}$ & $6522 / 0.0468$ & $6706 / 0.0575$ & $6234 / 0.0447$ & $6494 / 0.0593$ & $6454 / 0.0633$ \\
\hline Params & 344 & 344 & 406 & 344 & 344 \\
\hline GOF on $F^{2}$ & 0.989 & 1.074 & 0.946 & 1.028 & 1.148 \\
\hline$R_{1}, w R_{2}[I>2 \sigma(I)]$ & $0.0430,0.0918$ & $0.0543,0.1249$ & $0.0471,0.0963$ & $0.0570,0.1318$ & $0.0794,0.1860$ \\
\hline$R_{1}, w R_{2}$ (all data) & $0.0612,0.1009$ & $0.0728,0.1366$ & $0.0659,0.1060$ & $0.0858,0.1520$ & $0.0993,0.2011$ \\
\hline
\end{tabular}




\begin{tabular}{|c|c|c|c|c|c|}
\hline & 3Ea & 3Ec & $3 F a$ & $3 \mathrm{Ha}$ & $3 \mathrm{Hb}$ \\
\hline formula & $\mathrm{C}_{33} \mathrm{H}_{39} \mathrm{~B}_{2} \mathrm{~F}_{3} \mathrm{O}_{2}$ & $\mathrm{C}_{33} \mathrm{H}_{39} \mathrm{~B}_{2} \mathrm{~F}_{3} \mathrm{O}_{2}$ & $\mathrm{C}_{34} \mathrm{H}_{42} \mathrm{~B}_{2} \mathrm{O}_{4}$ & $\mathrm{C}_{32} \mathrm{H}_{46} \mathrm{~B}_{2} \mathrm{O}_{2}$ & $\mathrm{C}_{32} \mathrm{H}_{46} \mathrm{~B}_{2} \mathrm{O}_{2}$ \\
\hline fw & 546.26 & 546.26 & 536.29 & 484.31 & 484.31 \\
\hline $\mathrm{T}(\mathrm{K})$ & $93(2)$ & $93(2)$ & 93(2) & $93(2)$ & $93(2)$ \\
\hline$\lambda(\AA)$ & 0.71075 & 0.71075 & 0.71075 & 0.71075 & 0.71075 \\
\hline cryst syst & Triclinic & Triclinic & Monoclinic & Monoclinic & Monoclinic \\
\hline space group & $P-1$ & $P-1$ & $P 2_{1} / c$ & $P 2_{1} / c$ & $P 2_{1} / a$ \\
\hline $\mathrm{a},(\AA)$ & $14.316(3)$ & $8.4771(16)$ & $8.3097(13)$ & $12.329(3)$ & $17.040(3)$ \\
\hline $\mathrm{b},(\AA)$ & $14.506(2)$ & $12.1269(17)$ & $15.205(3)$ & $18.695(4)$ & $9.1931(17)$ \\
\hline $\mathrm{c},(\AA)$ & $15.944(3)$ & $16.329(3)$ & $24.874(4)$ & $13.813(3)$ & $18.793(4)$ \\
\hline$\alpha,(\operatorname{deg})$ & $90.042(2)$ & $70.166(8)$ & 90 & 90 & 90 \\
\hline$\beta,(\operatorname{deg})$ & $112.231(3)$ & $81.088(9)$ & $95.552(3)^{\circ}$. & $113.385(3)$ & $95.083(3)$ \\
\hline$\gamma,(\operatorname{deg})$ & $94.799(2)$ & $69.721(8)$ & 90 & 90 & 90 \\
\hline$V,\left(\AA^{3}\right)$ & $3052.4(9)$ & $1479.9(5)$ & $3128.1(9)$ & 2922.3(12) & 2932.4(10) \\
\hline Z & 4 & 2 & 4 & 4 & 4 \\
\hline$D_{\text {calc }},\left(\mathrm{g} / \mathrm{cm}^{3}\right)$ & 1.189 & 1.226 & 1.139 & 1.101 & 1.097 \\
\hline$\mu\left(\mathrm{mm}^{-1}\right)$ & 0.083 & 0.086 & 0.072 & 0.065 & 0.065 \\
\hline $\mathrm{F}(000)$ & 1160 & 580 & 1142 & 1056 & 1056 \\
\hline cryst size (mm) & $0.20 \times 0.18 \times 0.15$ & $0.20 \times 0.20 \times 0.18$ & $0.20 \times 0.20 \times 0.16$ & $0.20 \times 0.19 \times 0.14$ & $0.20 \times 0.15 \times 0.05$ \\
\hline $2 \theta$ range, $(\mathrm{deg})$ & $3.057-27.642$ & $3.234-27.464$ & $3.092-27.498$ & $3.050-27.469$ & $3.094-27.465$ \\
\hline reflns collected & 25371 & 12158 & 25386 & 23705 & 23329 \\
\hline indep reflns $/ \mathrm{R}_{\text {int }}$ & $13430 / 0.0420$ & $6512 / 0.0319$ & $7165 / 0.0547$ & $6649 / 0.0550$ & $6671 / 0.0608$ \\
\hline Params & 797 & 371 & 372 & 335 & 335 \\
\hline GOF on $F^{2}$ & 0.979 & 0.977 & 1.043 & 1.103 & 1.113 \\
\hline$R_{1}, w R_{2}[I>2 \sigma(I)]$ & $0.0611,0.1369$ & $0.0491,0.1160$ & $0.0623,0.1452$ & $0.0673,0.1568$ & $0.0869,0.2113$ \\
\hline$R_{1}, w R_{2}$ (all data) & $0.1097,0.1676$ & $0.0802,0.1436$ & $0.0922,0.1653$ & $0.0933,0.1752$ & $0.1140,0.2370$ \\
\hline
\end{tabular}




\begin{tabular}{|c|c|c|c|c|c|c|}
\hline & 4 & $5 \mathbf{a}$ & $5 c$ & {$\left[6(\text { thf })_{2}\right]_{2} \cdot \mathrm{THF}$} & $7(\text { thf })_{2} \cdot$ THF & $11 \mathrm{a} \cdot \mathrm{C}_{6} \mathrm{H}_{6}$ \\
\hline formula & $\mathrm{C}_{32} \mathrm{H}_{48} \mathrm{~B}_{2} \mathrm{O}_{2}$ & $\mathrm{C}_{33} \mathrm{H}_{42} \mathrm{~B}_{2} \mathrm{O}_{2}$ & $\mathrm{C}_{33} \mathrm{H}_{42} \mathrm{~B}_{2} \mathrm{O}_{2}$ & $\mathrm{C}_{84} \mathrm{H}_{118} \mathrm{~B}_{4} \mathrm{Li}_{2} \mathrm{O}_{9}$ & $\mathrm{C}_{44} \mathrm{H}_{63} \mathrm{~B}_{2} \mathrm{LiO}_{5}$ & $\mathrm{C}_{53} \mathrm{H}_{49} \mathrm{BN}_{2}$ \\
\hline fw & 486.32 & 492.28 & 492.28 & 1328.90 & 1077.00 & 724.75 \\
\hline $\mathrm{T}(\mathrm{K})$ & $93(2)$ & $93(2)$ & $93(2)$ & $93(2)$ & $93(2)$ & $93(2)$ \\
\hline$\lambda(\AA)$ & 0.71075 & 0.71075 & 0.71075 & 0.71075 & 0.71075 & 0.71075 \\
\hline cryst syst & Monoclinic & Monoclinic & Monoclinic & Monoclinic & Monoclinic & Triclinic \\
\hline space group & $P 2_{1} / a$ & $P 2_{1} / c$ & $P 2_{1} / n$ & $P 2_{1} / c$ & $P 2_{1} / c$ & $P-1$ \\
\hline $\mathrm{a},(\AA)$ & $16.161(10)$ & $11.883(4)$ & $12.983(4)$ & $12.550(3)$ & $14.109(5)$ & $12.691(4)$ \\
\hline $\mathrm{b},(\AA)$ & $11.258(7)$ & $18.855(6)$ & $15.773(4)$ & $12.708(3)$ & $16.835(6)$ & $12.716(4)$ \\
\hline c, $(\AA)$ & $16.744(11)$ & $14.062(5)$ & $15.498(5)$ & $24.259(6)$ & $17.564(7)$ & $13.967(4)$ \\
\hline$\alpha,(\operatorname{deg})$ & 90 & 90 & 90 & 90 & 90 & $91.217(3)$ \\
\hline$\beta,(\operatorname{deg})$ & $98.720(9)$ & $114.901(5)$ & $113.439(4)$ & $93.879(6)$ & $99.436(7)$ & $112.083(5)$ \\
\hline$\gamma,(\operatorname{deg})$ & 90 & 90 & 90 & 90 & 90 & $104.500(3)$ \\
\hline$V,\left(\AA^{3}\right)$ & 3011(3) & $2857.7(18)$ & $2911.7(14)$ & $3860.2(17)$ & $4115(3)$ & 2005.3(11) \\
\hline Z & 4 & 4 & 4 & 2 & 4 & 2 \\
\hline $\mathrm{D}_{\text {calc }},\left(\mathrm{g} / \mathrm{cm}^{3}\right)$ & 1.073 & 1.144 & 1.123 & 1.143 & 1.131 & 1.200 \\
\hline$\mu\left(\mathrm{mm}^{-1}\right)$ & 0.063 & 0.068 & 0.066 & 0.071 & 0.070 & 0.068 \\
\hline $\mathrm{F}(000)$ & 1064 & 1064 & 1064 & 1440 & 1520 & 772 \\
\hline cryst size (mm) & $0.20 \times 0.18 \times 0.15$ & $0.19 \times 0.17 \times 0.05$ & $0.17 \times 0.15 \times 0.04$ & $0.18 \times 0.15 \times 0.10$ & $0.20 \times 0.10 \times 0.04$ & $0.20 \times 0.18 \times 0.10$ \\
\hline $2 \theta$ range, $(\mathrm{deg})$ & $3.055-25.996$ & $3.136-25.998$ & $3.098-25.997$ & $3.206-26.000$ & $3.154-25.000$ & $3.175-25.999$ \\
\hline reflns collected & 21386 & 20814 & 21108 & 28210 & 27801 & 14922 \\
\hline indep reflns $/ \mathrm{R}_{\text {int }}$ & $5901 / 0.0738$ & $5599 / 0.0452$ & $5709 / 0.0742$ & $7573 / 0.0821$ & $7223 / 0.1312$ & $7711 / 0.0623$ \\
\hline Params & 337 & 345 & 348 & 594 & 562 & 499 \\
\hline GOF on $F^{2}$ & 0.996 & 1.145 & 1.097 & 1.054 & 1.051 & 1.032 \\
\hline$R_{1}, w R_{2}[I>2 \sigma(I)]$ & $0.0694,0.1578$ & $0.0668,0.1552$ & $0.0742,0.1542$ & $0.0739,0.1650$ & $0.0790,0.1762$ & $0.0701,0.1527$ \\
\hline$R_{1}, w R_{2}$ (all data) & $0.1034,0.1826$ & $0.0845,0.1681$ & $0.1102,0.1737$ & $0.1152,0.1917$ & $0.1227,0.1996$ & $0.1186,0.1832$ \\
\hline
\end{tabular}




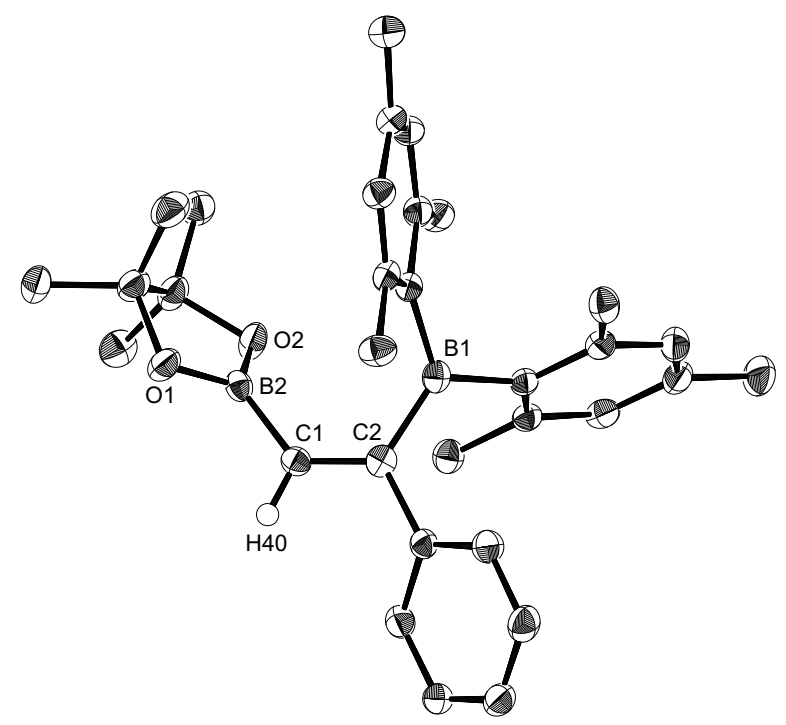

Figure S97. ORTEP drawing of 2a (50\% thermal ellipsoids, hydrogen atoms except for H40 are omitted for clarity)

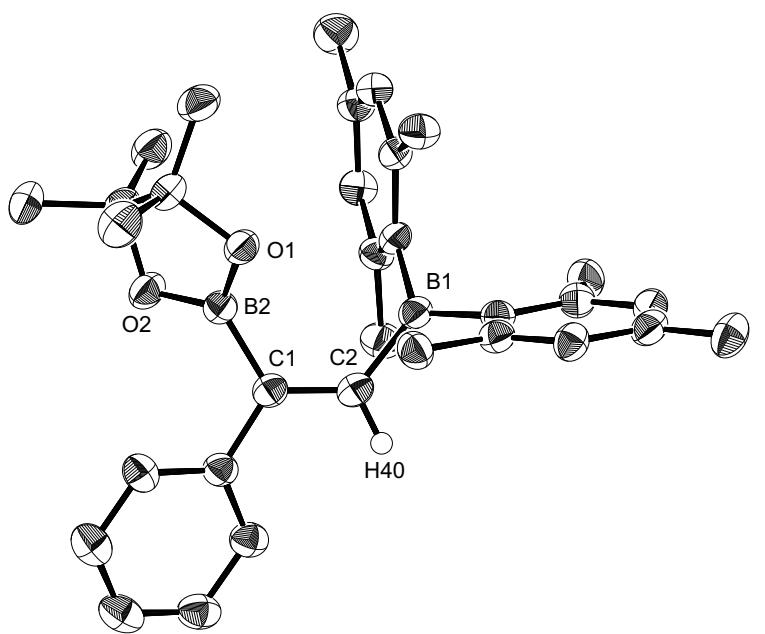

Figure S98. ORTEP drawing of $\mathbf{2 b}$ (50\% thermal ellipsoids, hydrogen atoms except for $\mathrm{H} 40$ are omitted for clarity)

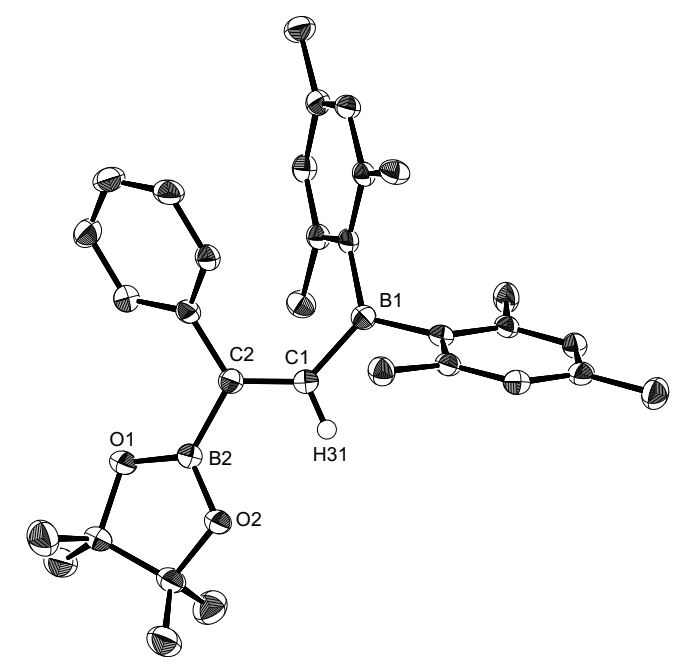

Figure S99. ORTEP drawing of $\mathbf{2 c}$ (50\% thermal ellipsoids, hydrogen atoms except for H31 are omitted for clarity) 


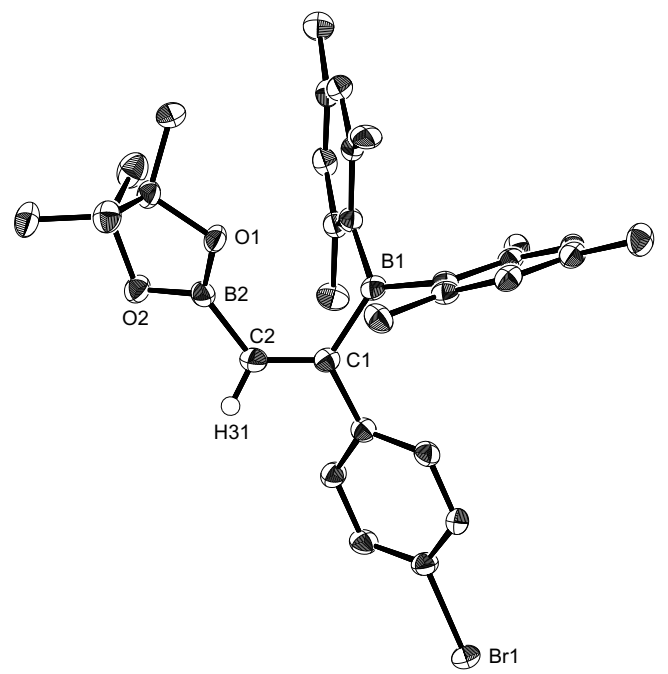

Figure S100. ORTEP drawing of 3Aa (50\% thermal ellipsoids, hydrogen atoms except for H31 are omitted for clarity)

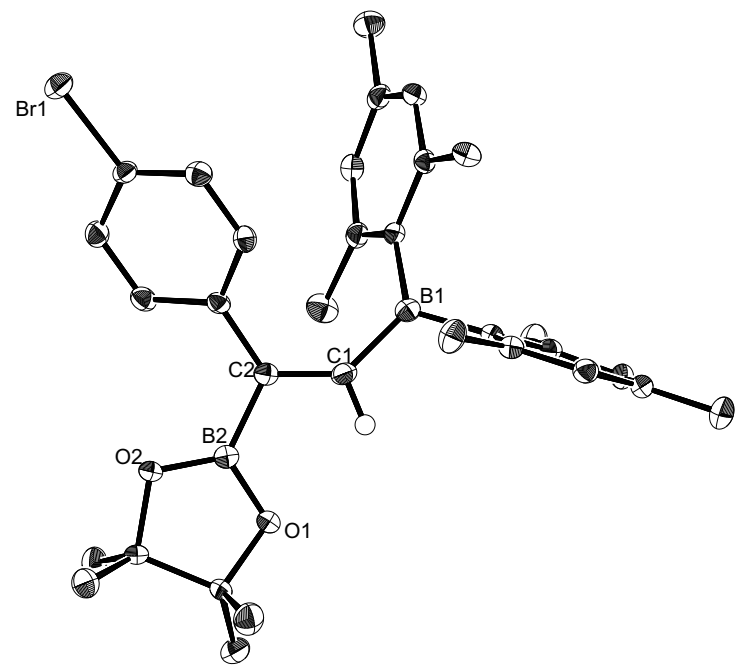

Figure S101. ORTEP drawing of 3Ac (50\% thermal ellipsoids, hydrogen atoms except for alkenyl proton are omitted for clarity)

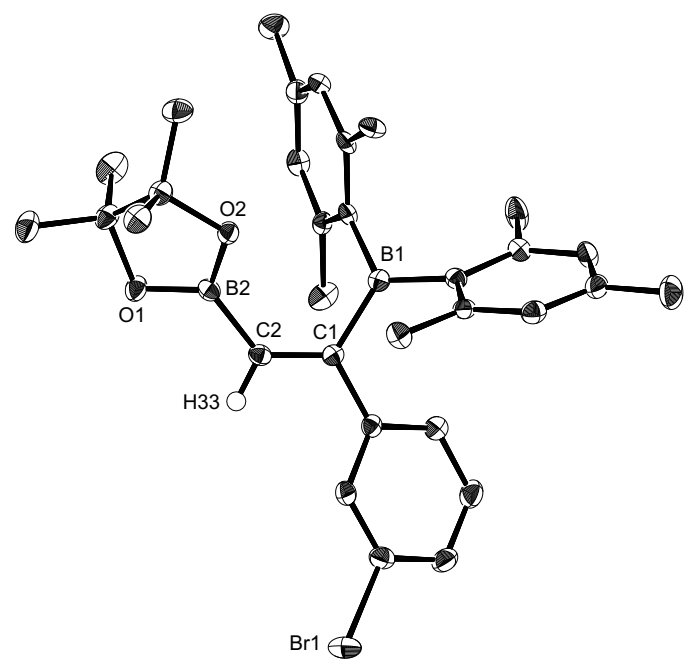

Figure S102. ORTEP drawing of 3Ba (50\% thermal ellipsoids, hydrogen atoms except for H33 are omitted for clarity) 


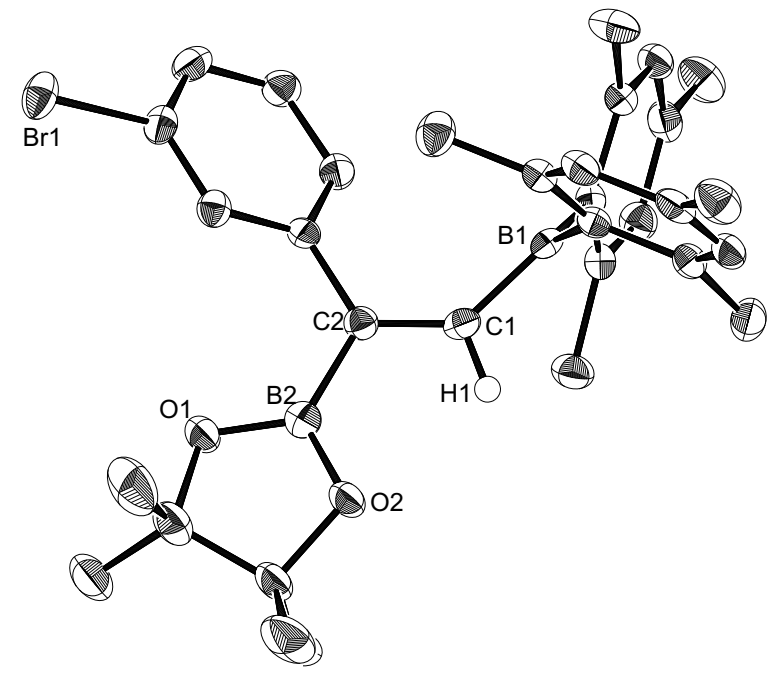

Figure S103. ORTEP drawing of $\mathbf{3 B c}$ (50\% thermal ellipsoids, hydrogen atoms except for H1 are omitted for clarity)

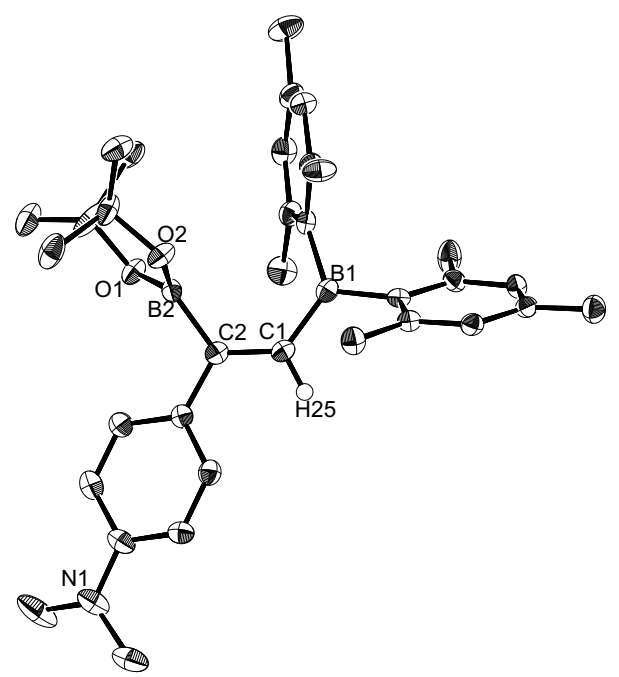

Figure S104. ORTEP drawing of $\mathbf{3 C b}$ (50\% thermal ellipsoids, hydrogen atoms except for $\mathrm{H} 25$ are omitted for clarity)

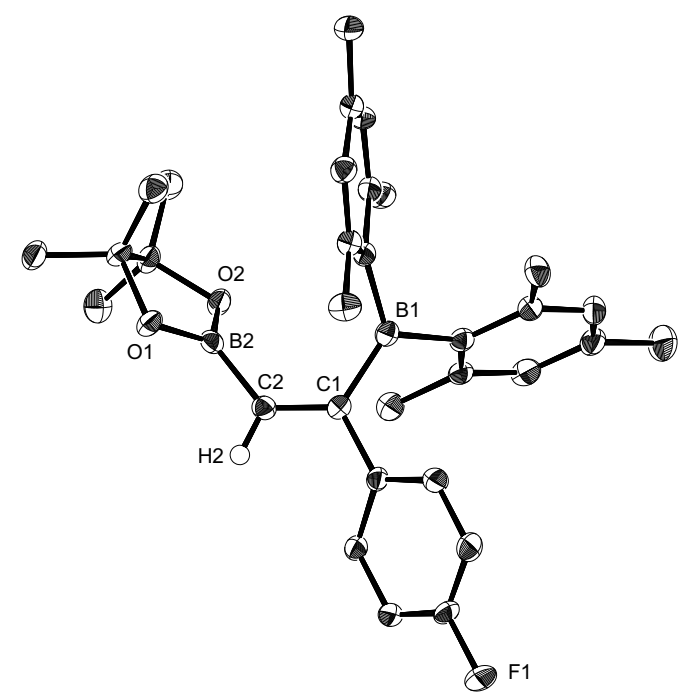

Figure S105. ORTEP drawing of 3Da (50\% thermal ellipsoids, hydrogen atoms except for $\mathrm{H} 2$ are omitted for clarity) 


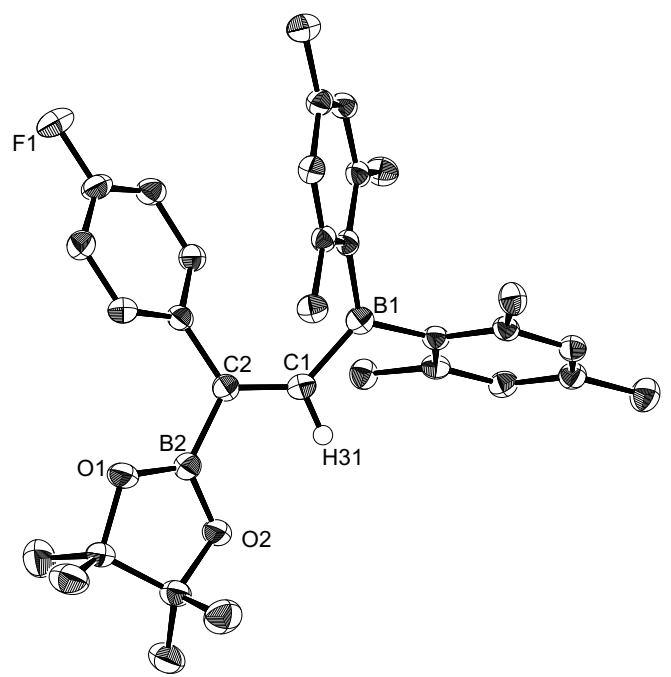

Figure S106. ORTEP drawing of 3Dc (50\% thermal ellipsoids, hydrogen atoms except for H31 are omitted for clarity)

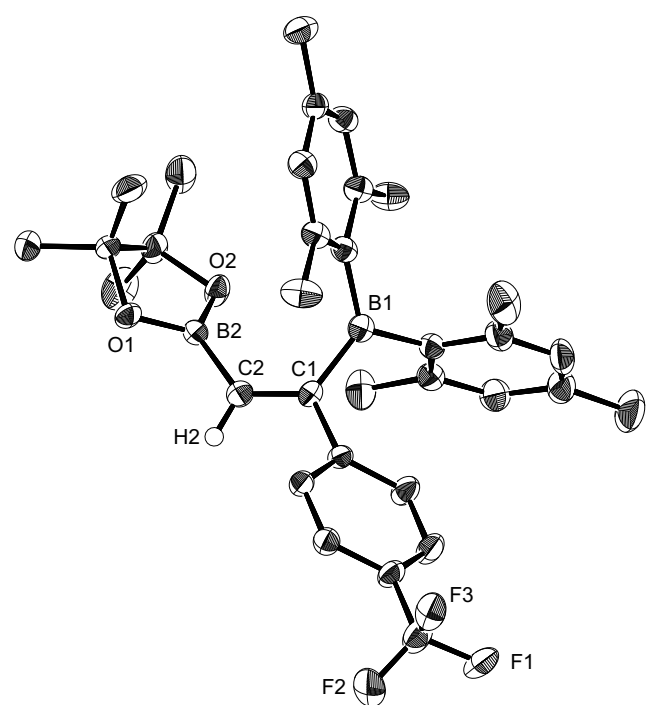

Figure S107. ORTEP drawing of 3Ea (50\% thermal ellipsoids, hydrogen atoms except for $\mathrm{H} 2$ are omitted for clarity)

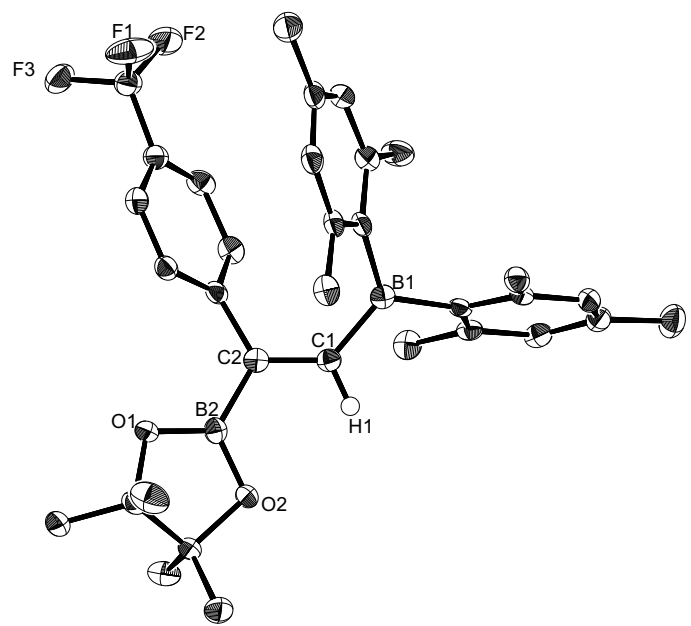

Figure S108. ORTEP drawing of 3Ec (50\% thermal ellipsoids, hydrogen atoms except for H1 are omitted for clarity) 


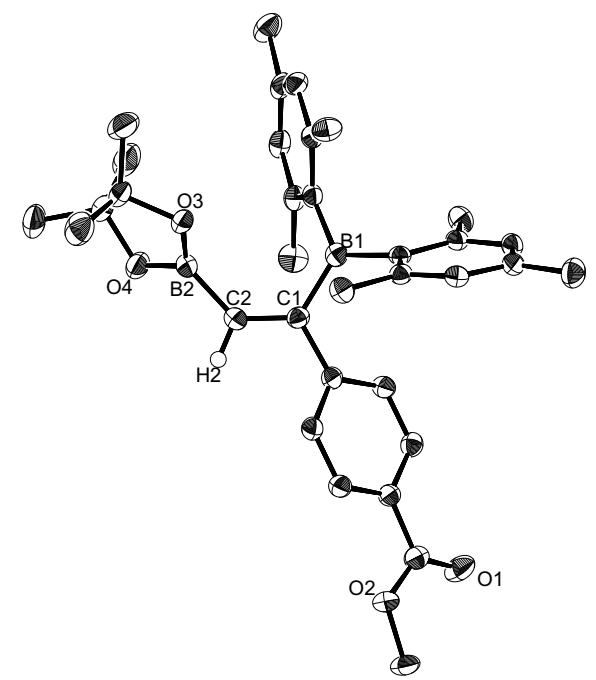

Figure S109. ORTEP drawing of 3Fa (50\% thermal ellipsoids, hydrogen atoms except for $\mathrm{H} 2$ are omitted for clarity)

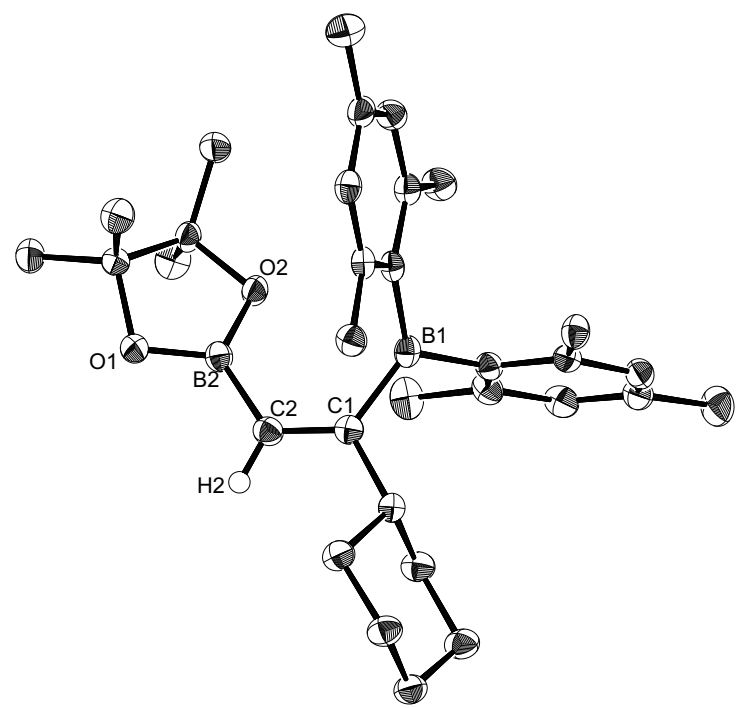

Figure S110. ORTEP drawing of $\mathbf{3 H a}$ (50\% thermal ellipsoids, hydrogen atoms except for $\mathrm{H} 2$ are omitted for clarity)

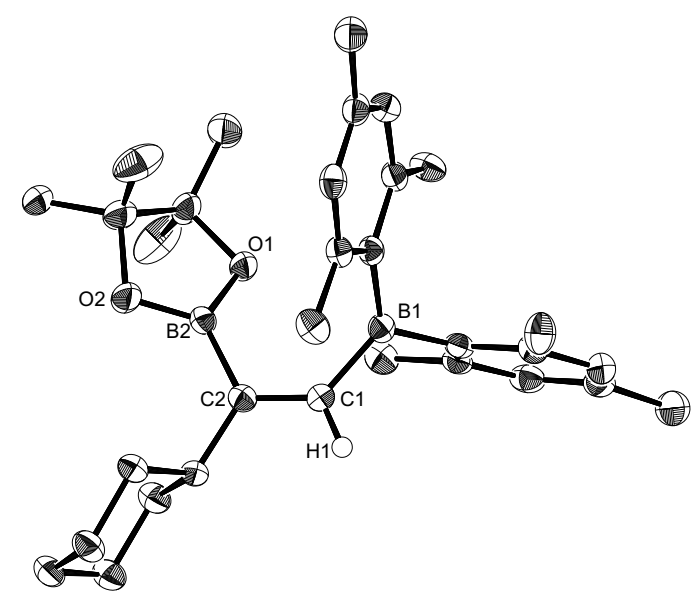

Figure S111. ORTEP drawing of $\mathbf{3 H b}$ (50\% thermal ellipsoids, hydrogen atoms except for $\mathrm{H} 1$ are omitted for clarity) 


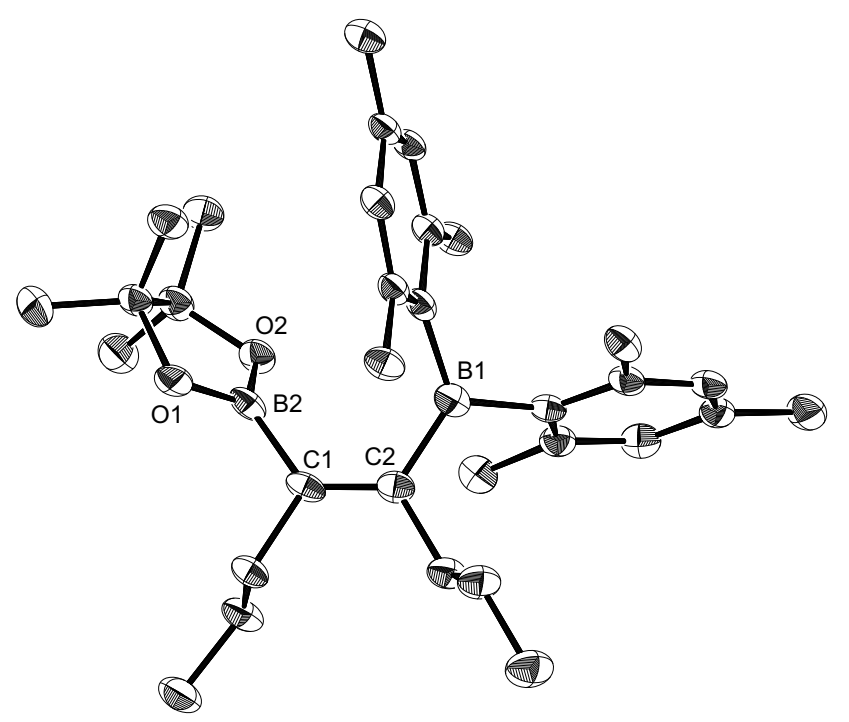

Figure S112. ORTEP drawing of 4 (50\% thermal ellipsoids, hydrogen atoms are omitted for clarity)

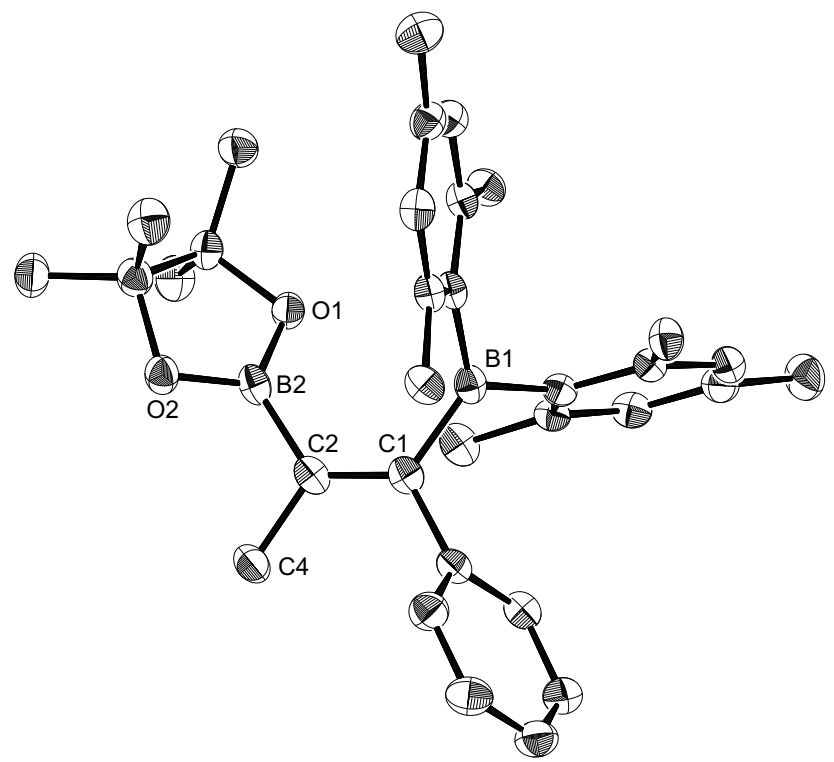

Figure S113. ORTEP drawing of 5a (50\% thermal ellipsoids, hydrogen atoms are omitted for clarity)

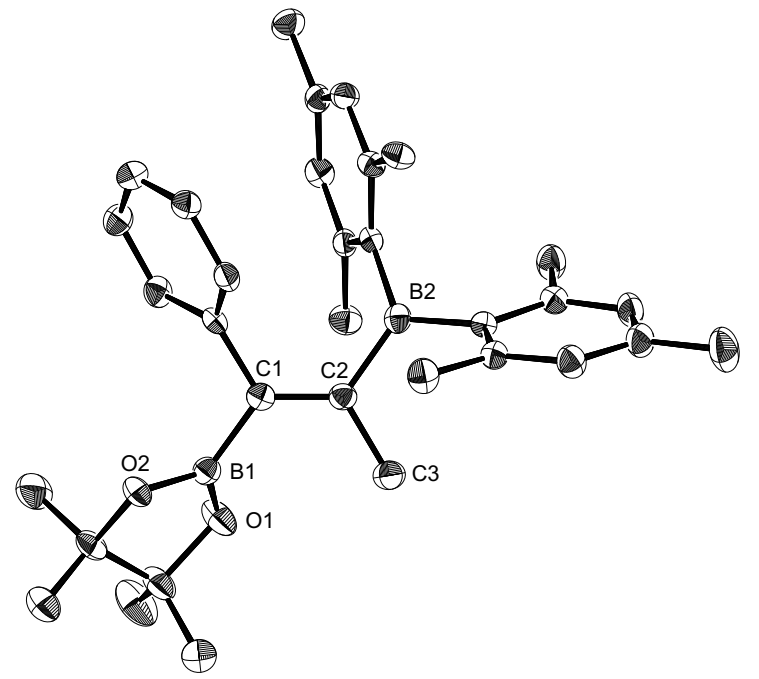

Figure S114. ORTEP drawing of 5c (50\% thermal ellipsoids, hydrogen atoms are omitted for clarity) 


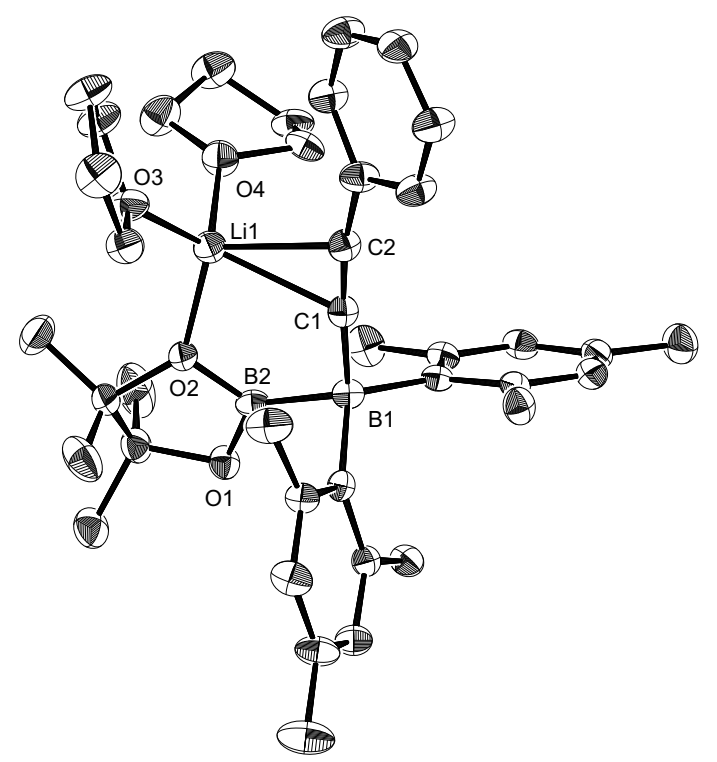

Figure S115. ORTEP drawing of $\mathbf{6}(\text { thf })_{2}(50 \%$ thermal ellipsoids, hydrogen atoms and co-crystallized THF molecule are omitted for clarity)

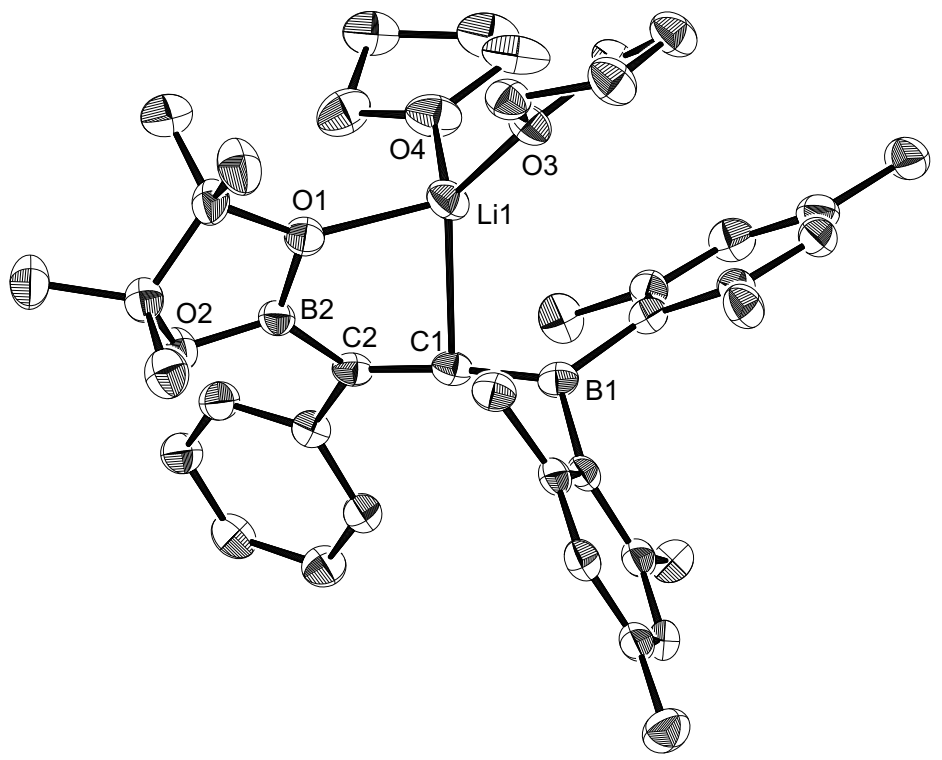

Figure S116. ORTEP drawing of $\mathbf{7}(\text { thf })_{2}(50 \%$ thermal ellipsoids, hydrogen atoms and co-crystallized THF molecule are omitted for clarity)

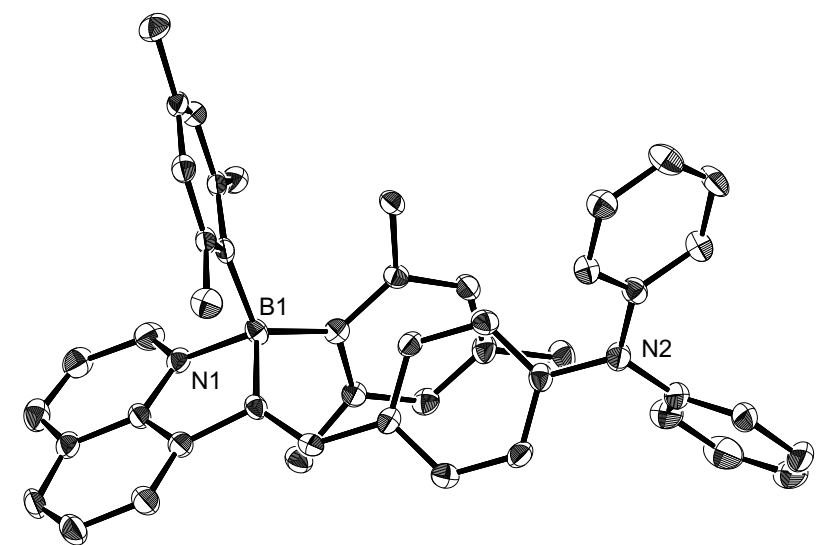

Figure S117. ORTEP drawing of 11a (50\% thermal ellipsoids, hydrogen atoms and co-crystallized benzene molecule are omitted for clarity) 
Table S2. Selected bond lengths $(\AA)$, sum of angles around italicized atom $\left(^{\circ}\right)$, and dihedral angles $\left(^{\circ}\right)$ of $\mathbf{2 a}, \mathbf{2 b}$,

2c, 3Aa, 3Ac, 3Ba, 3Bc, 3Cb, 3Da, 3Dc, 3Ea, 3Ec, 3Fa, 3Ha, 3Hc, 4, 5a, and 5c.

\begin{tabular}{|c|c|c|c|c|c|c|c|c|c|c|}
\hline cpd & C-BMes 2 & C-Bpin & $\mathrm{C}=\mathrm{C}$ & $\mathrm{C}-\mathrm{R}$ & $\Sigma \angle B\left(\mathrm{Mes}_{2}\right)$ & $\Sigma \angle B($ pin $)$ & $\Sigma \angle C-\mathrm{R}$ & Mes $-\mathrm{B}-\mathrm{C}=\mathrm{C}$ & $\mathrm{O}-\mathrm{B}-\mathrm{C}=\mathrm{C}$ & $\mathrm{C}-\mathrm{C}-\mathrm{C}=\mathrm{C}$ \\
\hline $2 \mathbf{a}$ & $1.580(4)$ & $1.549(4)$ & $1.355(3)$ & $1.495(3)$ & 360.0 & 359.6 & 359.8 & 49.1(3) & $58.9(4)$ & $37.1(3)$ \\
\hline $2 \mathrm{~b}$ & $1.567(6)$ & $1.562(6)$ & $1.358(6)$ & $1.497(6)$ & 359.8 & 359.9 & 360.0 & $-46.5(6)$ & $-44.6(6)$ & $-29.2(6)$ \\
\hline 2c & $1.569(3)$ & $1.568(3)$ & $1.358(3)$ & $1.488(3)$ & 359.8 & 360.0 & 360.0 & $-29.0(3)$ & $27.8(3)$ & $-42.1(3)$ \\
\hline 3Aa & $1.583(5)$ & $1.550(5)$ & $1.357(4)$ & $1.496(5)$ & 359.9 & 360.0 & 359.9 & $-51.1(4)$ & $-44.4(5)$ & $44.3(4)$ \\
\hline 3Ac & $1.568(3)$ & $1.579(3)$ & $1.357(3)$ & $1.486(3)$ & 359.3 & 360.0 & 360.0 & $-36.6(4)$ & $-5.1(3)$ & $-38.0(3)$ \\
\hline $3 \mathbf{B a}$ & $1.597(3)$ & $1.554(4)$ & $1.350(3)$ & $1.491(3)$ & 359.9 & 359.8 & 360.0 & $-47.9(3)$ & $-35.9(4)$ & $-26.5(3)$ \\
\hline $3 B \mathbf{c}$ & $1.565(4)$ & $1.559(4)$ & $1.352(3)$ & $1.494(4)$ & 359.4 & 360.0 & 360.0 & $-79.4(4)$ & $9.5(4)$ & $40.9(4)$ \\
\hline $3 \mathbf{C b}$ & $1.538(4)$ & $1.581(5)$ & $1.362(4)$ & $1.482(4)$ & 359.9 & 359.5 & 359.9 & $-26.5(5)$ & $-75.5(4)$ & $26.4(4)$ \\
\hline 3Da & $1.578(3)$ & $1.557(3)$ & $1.352(2)$ & $1.493(2)$ & 360.0 & 359.8 & 359.8 & $49.2(3)$ & $60.2(3)$ & $37.5(2)$ \\
\hline 3Dc & $1.575(3)$ & $1.578(3)$ & $1.360(3)$ & $1.486(3)$ & 359.9 & 360.0 & 359.9 & $25.9(4)$ & $-24.8(3)$ & $41.5(3)$ \\
\hline & $1.583(3)$ & $1.550(4)$ & $1.345(3)$ & $1.506(4)$ & 359.9 & 360.0 & 360.0 & $56.9(3)$ & $43.2(4)$ & $-44.8(3)$ \\
\hline & $1.587(3)$ & $1.549(3)$ & $1.348(3)$ & $1.498(3)$ & 360.0 & 360.0 & 360.0 & $-58.3(3)$ & $-39.4(4)$ & $39.3(3)$ \\
\hline 3Ec & $1.587(3)$ & $1.549(3)$ & $1.348(3)$ & $1.498(3)$ & 359.9 & 359.9 & 359.8 & $29.0(3)$ & $-17.2(3)$ & $52.7(3)$ \\
\hline $3 \mathbf{F a}$ & $1.562(3)$ & $1.563(3)$ & $1.364(3)$ & $1.488(2)$ & 360.0 & 359.5 & 359.9 & $-38.6(2)$ & $-59.8(3)$ & $-38.4(2)$ \\
\hline $3 \mathrm{Ha}$ & $1.586(3)$ & $1.540(3)$ & $1.349(2)$ & $1.538(3)$ & 359.7 & 360.0 & 359.9 & $62.5(3)$ & $24.2(3)$ & - \\
\hline $3 \mathbf{H c}$ & $1.570(4)$ & $1.562(4)$ & $1.345(3)$ & $1.517(3)$ & 359.6 & 356.6 & 359.9 & $57.7(4)$ & $29.5(3)$ & - \\
\hline 4 & $1.575(3)$ & $1.574(4)$ & $1.367(3)$ & $\begin{array}{l}1.535(3) \\
1.536(3)\end{array}$ & 360.0 & 359.3 & $\begin{array}{l}359.6 \\
359.9\end{array}$ & $37.8(3)$ & $61.1(4)$ & - \\
\hline $5 a$ & $1.582(4)$ & $1.559(4)$ & $1.355(3)$ & $\begin{array}{l}1.508(3) \\
1.515(4)\end{array}$ & 359.9 & 359.9 & $\begin{array}{l}359.9 \\
359.9\end{array}$ & $59.3(3)$ & $35.3(3)$ & - \\
\hline $5 c$ & $1.585(3)$ & $1.567(3)$ & $1.359(3)$ & $\begin{array}{l}1.498(3) \\
1.522(4)\end{array}$ & 359.5 & 359.7 & $\begin{array}{l}359.9 \\
359.9\end{array}$ & $-38.3(4)$ & $-46.7(4)$ & - \\
\hline
\end{tabular}




\section{Computational details}

The crystal structures of $\mathbf{6}(\mathbf{t h f})_{2}, \mathbf{7}(\mathbf{t h f})_{2}$, and 11a were employed as the initial structures for the geometry optimization calculations without symmetry constraints at the Becke 3LYP (B3LYP) level of density functional theory. ${ }^{6}$ The $6-31+\mathrm{G}(\mathrm{d})$ basis set was used for Li atom and the 6-31G(d) basis set was used for all the remaining atoms $(\mathrm{B}, \mathrm{C}, \mathrm{O}$, and $\mathrm{H}){ }^{7}$ Frequency calculations at the same level of theory were performed to verify the stationary points as minimum (zero imaginary frequency) and to provide vibration frequency information. For the TD-DFT calculations of 11a and 11d, we first optimized the structures at the B3LYP/6-31+G(d,p) level of theory. ${ }^{6 a-c, 7}$ Then, the TD-DFT calculations ${ }^{8}$ were performed at the CAM-B3LYP/6-31+G(d,p) level on the basis of the optimized structures. ${ }^{9}$ All the calculations were performed with Gaussian 09 (rev. D.01) package. ${ }^{10}$

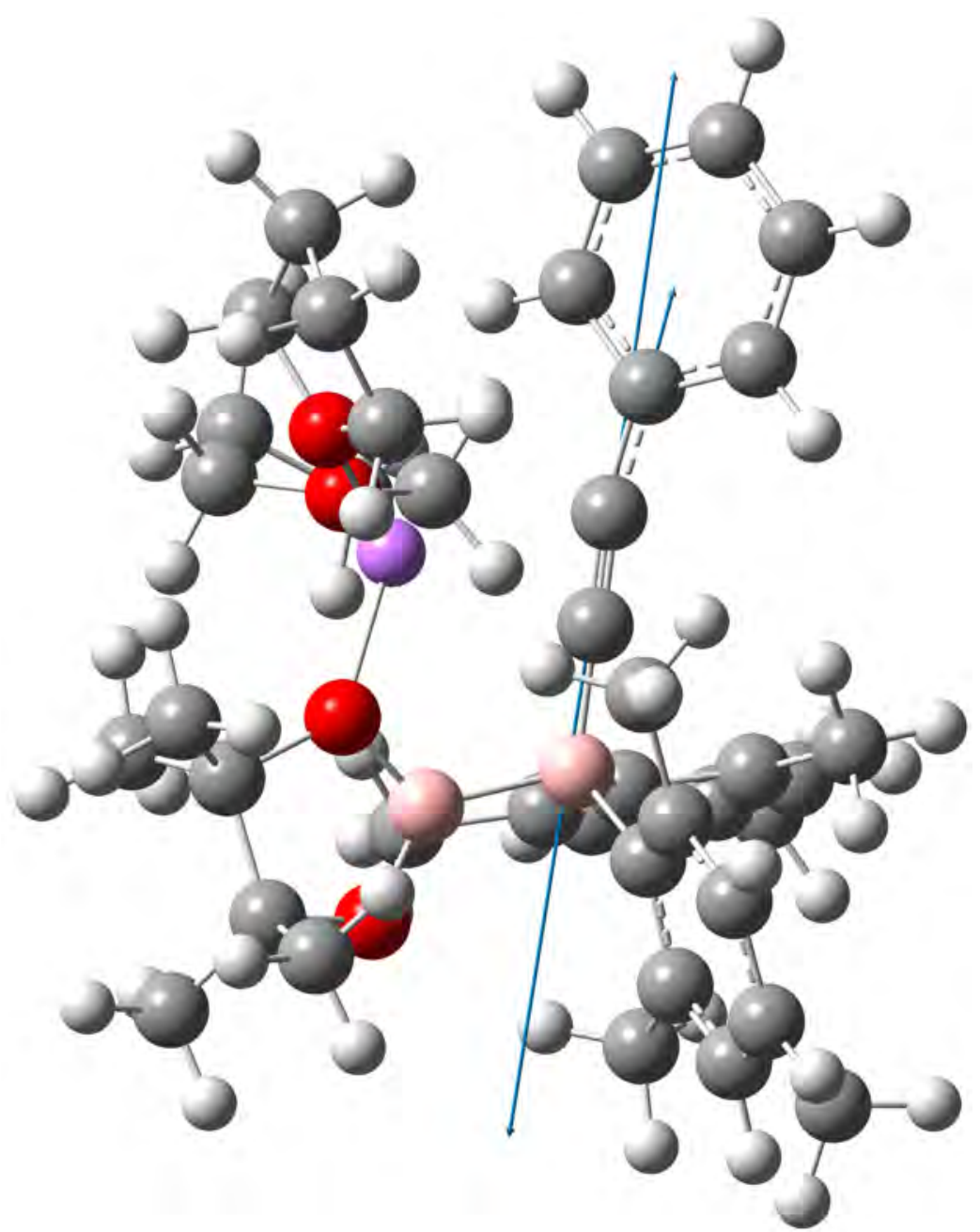

Figure S118. Calculated displacement vertor at $2172 \mathrm{~cm}^{-1}$ (scaled with 0.991$)^{11}$ for $\mathbf{6}(\mathbf{t h f})_{2}$ (gray: carbon, pale orange: boron, red: oxygen, white: hydrogen, purple: lithium) 


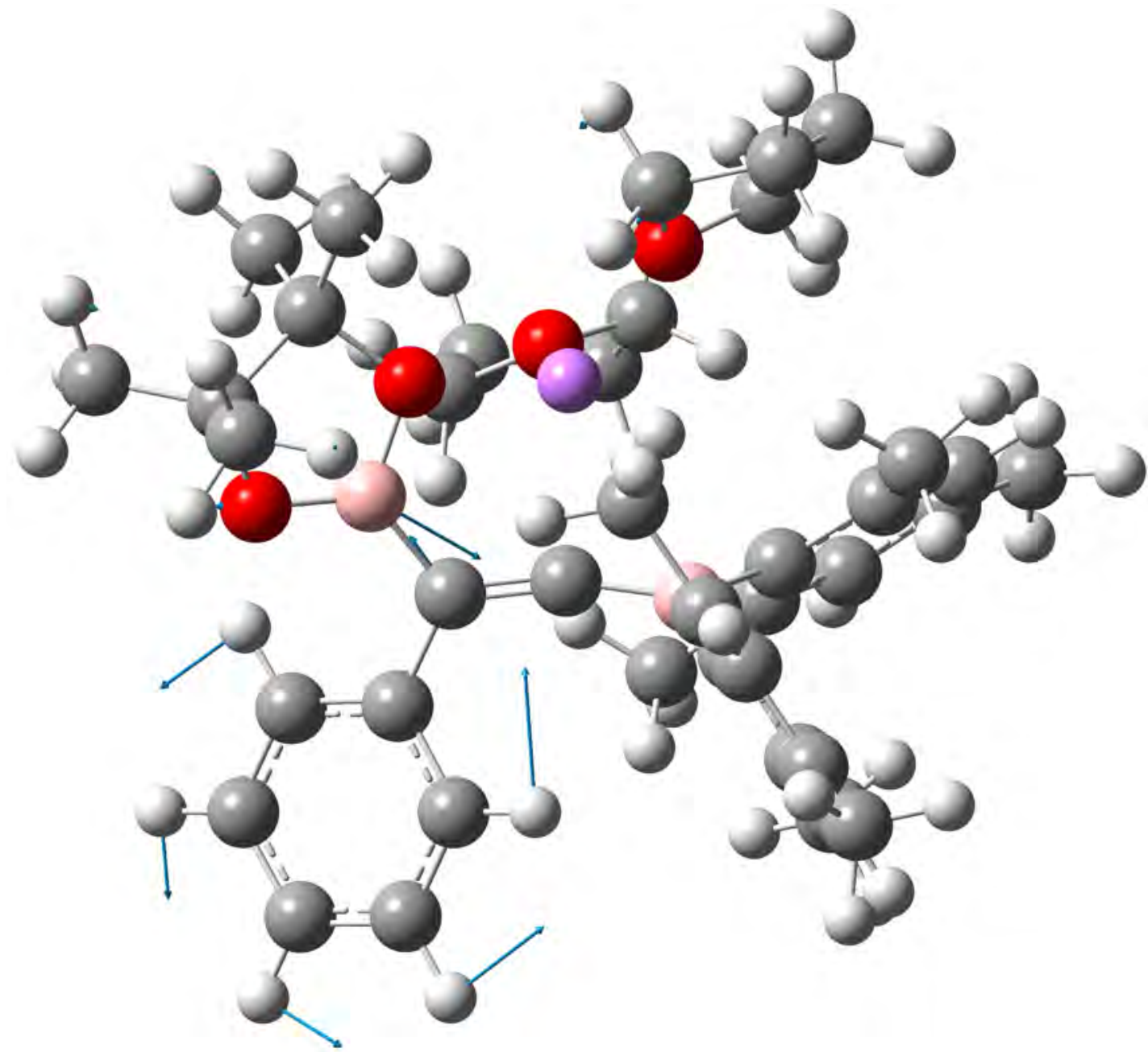

Figure S119. Calculated displacement vertor at $1369 \mathrm{~cm}^{-1}$ (scaled with 0.991$)^{11}$ for $7(\text { thf })_{2}$ (gray: carbon, pale orange: boron, red: oxygen, white: hydrogen, purple: lithium) 


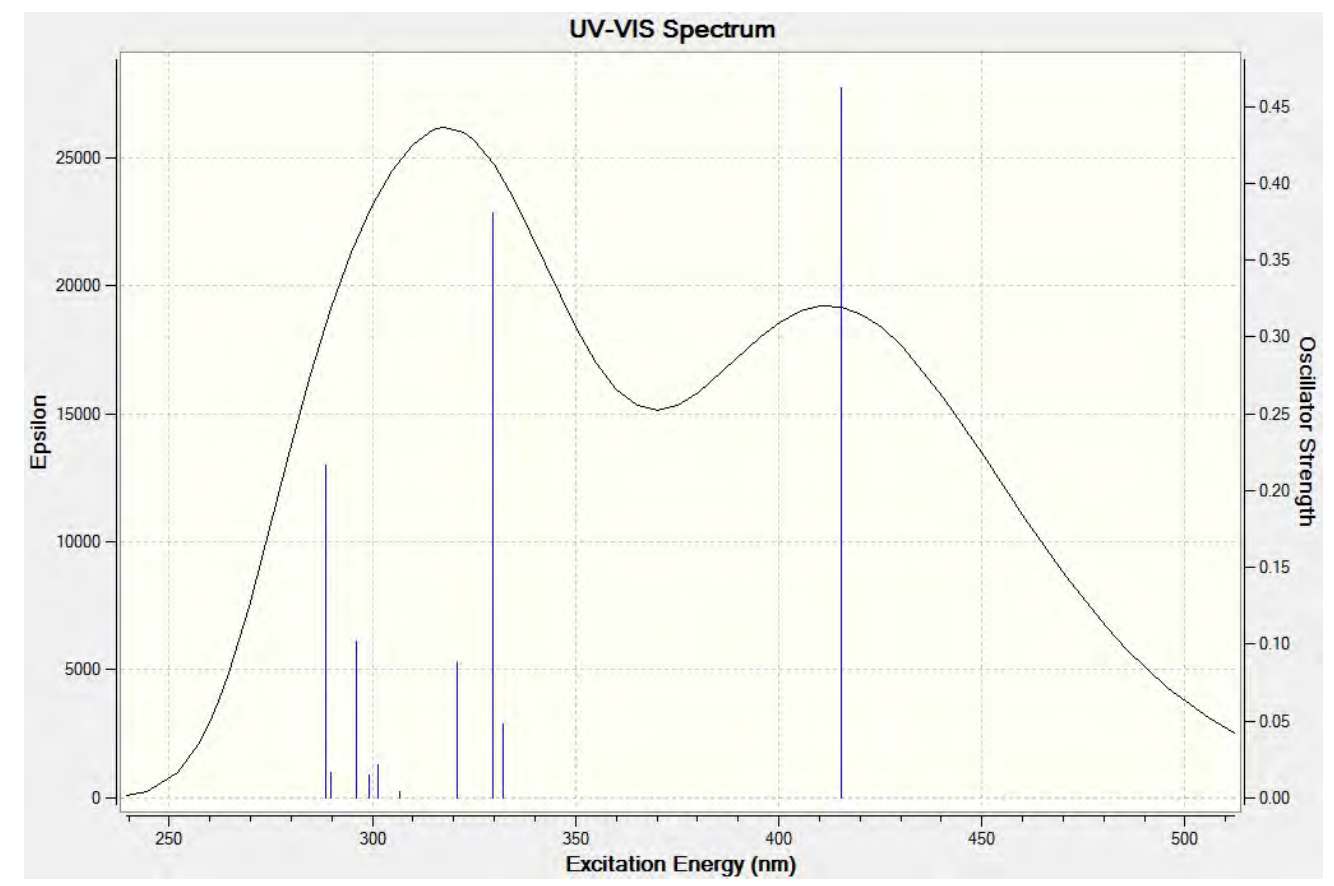

Figure S120. Simulated absorption spectrum of 11a

Table S3. Summary for TD-DFT calculation for 11a

\begin{tabular}{|c|c|c|c|c|}
\hline Excited State 1 : & Singlet-A & $2.9860 \mathrm{eV} \quad 415.22 \mathrm{~nm}$ & $\mathrm{f}=0.4620$ & $<\mathrm{S} * * 2>=0.000$ \\
\hline $172->173$ & 0.60998 & HOMO to LUMO & & \\
\hline Excited State & Singlet-A & $3.7603 \mathrm{eV} \quad 329.72 \mathrm{~nm}$ & $\mathrm{f}=0.3807$ & $<\mathrm{S} * * 2>=0.000$ \\
\hline $171->173$ & -0.33964 & HOMO-1 to LUMO & & \\
\hline $172->174$ & 0.48108 & $\mathrm{HOMO}$ to $\mathrm{LUMO}+1$ & & \\
\hline Excited State & Singlet-A & $4.1877 \mathrm{eV} \quad 296.07 \mathrm{~nm}$ & $\mathrm{f}=0.1020$ & $<\mathrm{S} * * 2>=0.000$ \\
\hline $169->173$ & -0.29061 & HOMO-3 to LUMO & & \\
\hline $171->173$ & -0.21903 & HOMO-1 to LUMO & & \\
\hline $172->173$ & 0.22480 & HOMO to LUMO & & \\
\hline $172->175$ & 0.36465 & $\mathrm{HOMO}$ to $\mathrm{LUMO}+2$ & & \\
\hline Excited State 10: & Singlet-A & $4.2959 \mathrm{eV} \quad 288.61 \mathrm{~nm}$ & $\mathrm{f}=0.2165$ & $<\mathrm{S} * * 2>=0.000$ \\
\hline $172->178$ & 0.64496 & $\mathrm{HOMO}$ to $\mathrm{LUMO}+5$ & & \\
\hline
\end{tabular}




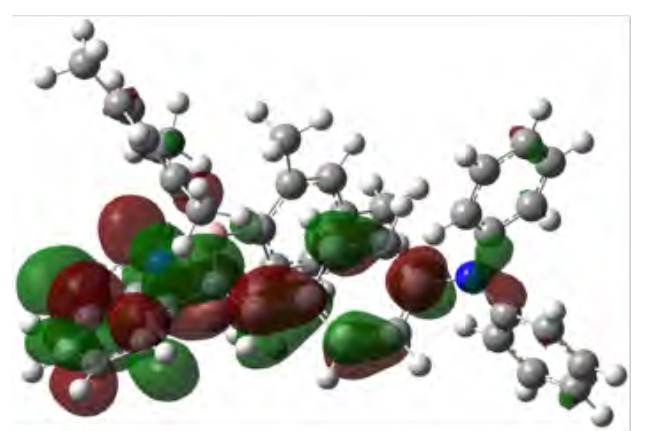

LUMO+1
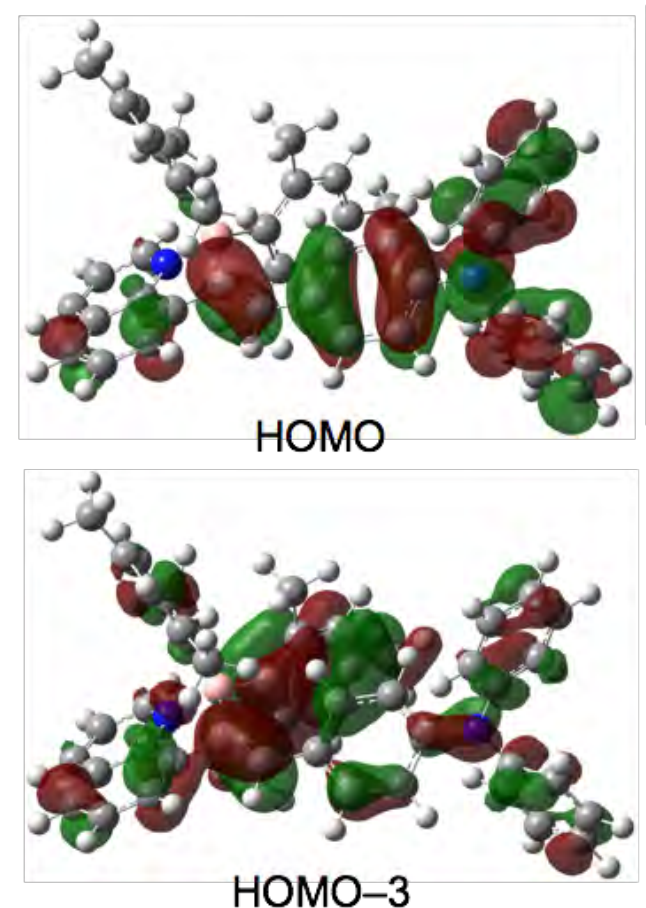

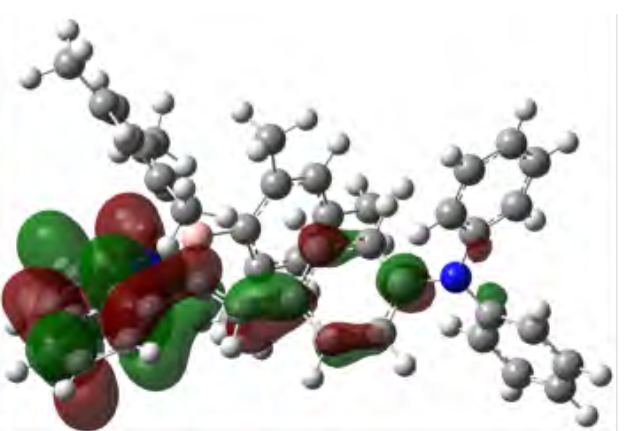

LUMO+2
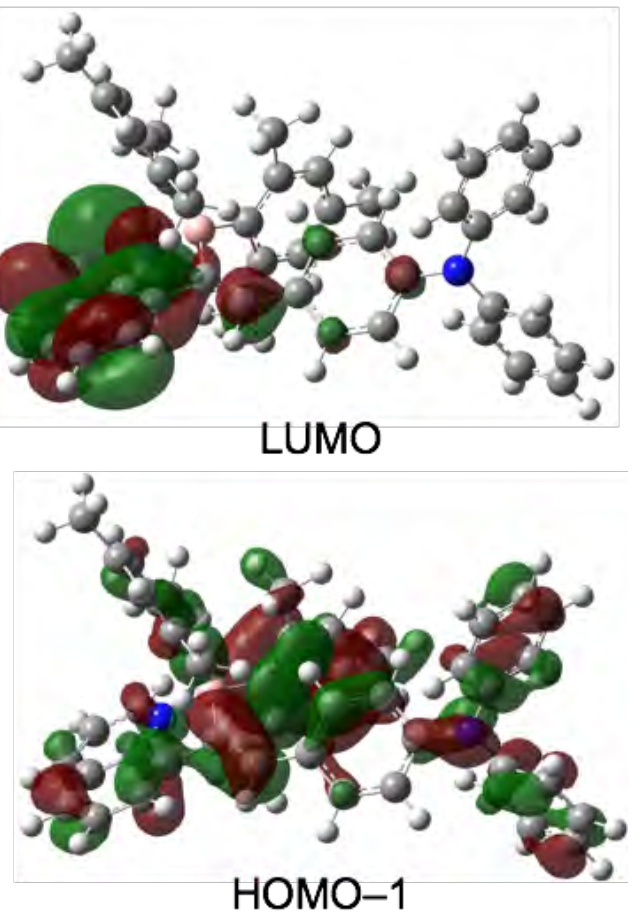

Figure S121. Molecular orbitals of 11a being related to DFT-calculated transitions 


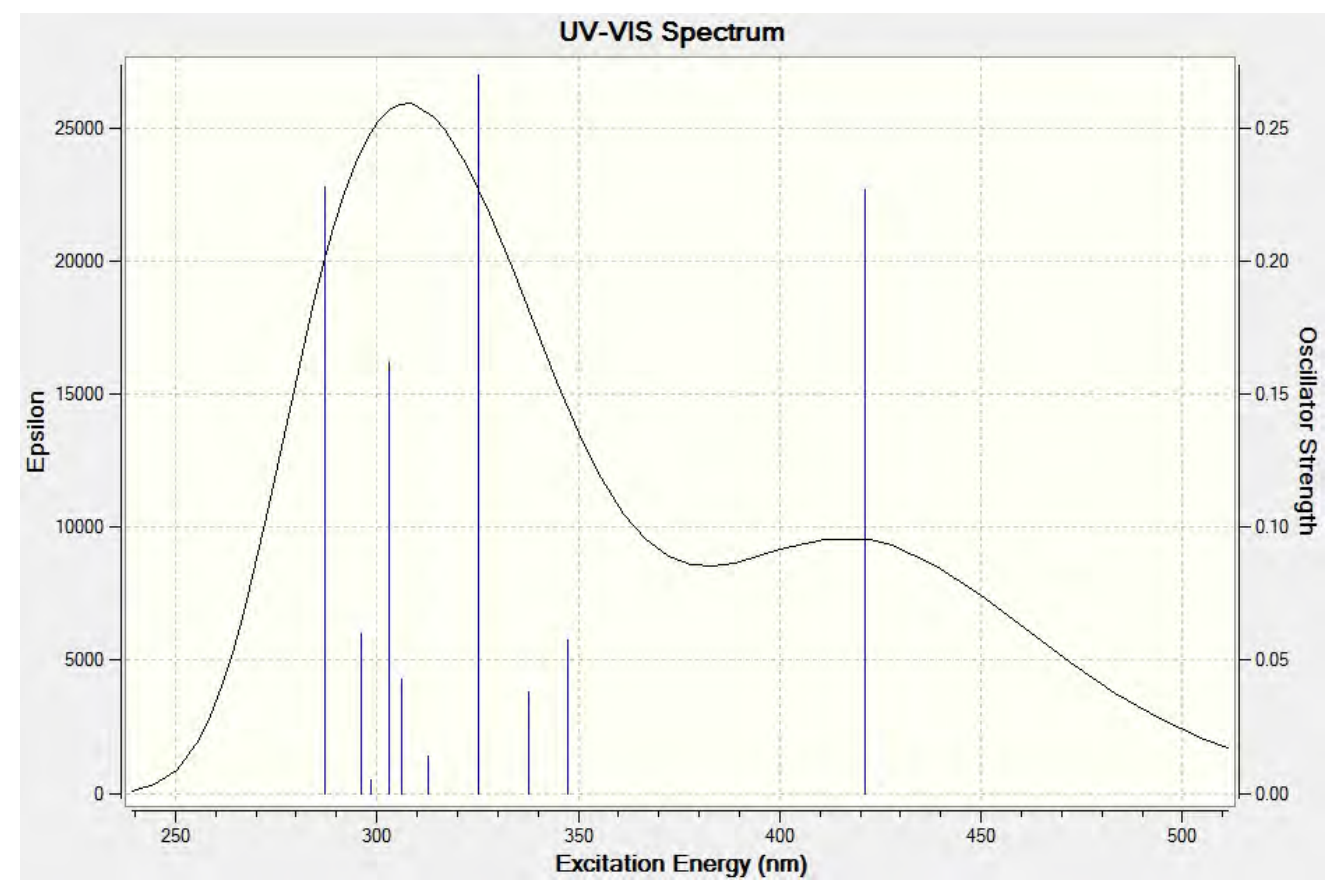

Figure S122. Simulated absorption spectrum of 11d

Table S4. Summary for TD-DFT calculation for 11d

\begin{tabular}{|c|c|c|c|c|}
\hline Excited State 1: & Singlet-A & $2.9435 \mathrm{eV} \quad 421.22 \mathrm{~nm}$ & $f=0.2267$ & $<\mathrm{S} * * 2>=0.000$ \\
\hline $172->173$ & 0.59638 & HOMO to LUMO & & \\
\hline Excited State & Singlet-A & $3.6712 \mathrm{eV} \quad 337.72 \mathrm{~nm}$ & $\mathrm{f}=0.0382$ & $<\mathrm{S} * * 2>=0.000$ \\
\hline $169->173$ & 0.40621 & HOMO-3 to LUMO & & \\
\hline $170->173$ & 0.50069 & HOMO-2 to LUMO & & \\
\hline Excited State & Singlet-A & $4.0909 \mathrm{eV} \quad 303.07 \mathrm{~nm}$ & $f=0.1622$ & $<\mathrm{S} * * 2>=0.000$ \\
\hline $172->175$ & 0.32127 & $\mathrm{HOMO}$ to $\mathrm{LUMO}+2$ & & \\
\hline $172->176$ & 0.46487 & $\mathrm{HOMO}$ to $\mathrm{LUMO}+3$ & & \\
\hline Excited State 10: & Singlet-A & $4.3172 \mathrm{eV} \quad 287.19 \mathrm{~nm}$ & $\mathrm{f}=0.2278$ & $<\mathrm{S} * * 2>=0.000$ \\
\hline $172->178$ & 0.63154 & $\mathrm{HOMO}$ to $\mathrm{LUMO}+5$ & & \\
\hline
\end{tabular}



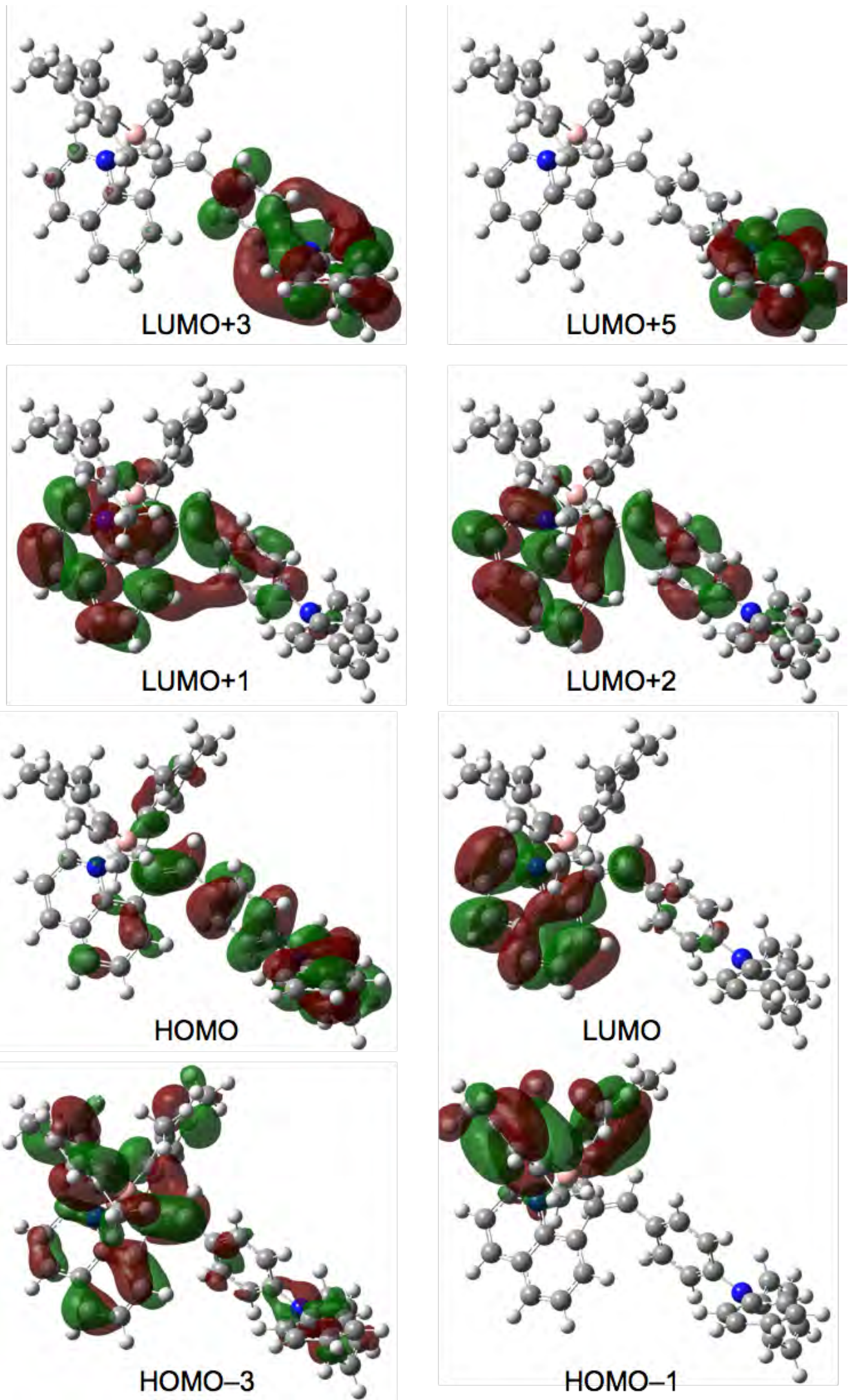

Figure S123. Molecular orbitals of 11d being related to DFT-calculated transitions 


\section{References}

(1) Asakawa, H.; Lee, K.-H.; Lin, Z.; Yamashita, M., Nat. Commun. 2014, 5, 4245.

(2) Greco, N. J.; Hysell, M.; Goldenberg, J. R.; Rheingold, A. L.; Tor, Y., Dalton Trans. 2006, 2288.

(3) (a) Kabuto, C.; Akine, S.; Nemoto, T.; Kwon, E., J. Cryst. Soc. Jpn. 2009, 51, 218; (b) Kabuto, C.; Akine, S.; Kwon, E., J. Cryst. Soc. Jpn. 2009, 51, 218.

(4) Burla, M. C.; Caliandro, R.; Carrozzini, B.; Cascarano, G. L.; Cuocci, C.; Giacovazzo, C.; Mallamo, M.; Mazzone, A.; Polidori, G., J. Appl. Crystallogr. 2015, 48, 306.

(5) Sheldrick, G., Act. Cryst. Sec. C 2015, 71, 3.

(6) (a) Lee, C.; Yang, W.; Parr, R. G., Phys. Rev. B 1988, 37, 785; (b) Becke, A. D., Phys. Rev. A 1988, 38, 3098; (c) Becke, A. D., J. Chem. Phys. 1993, 98, 5648; (d) Miehlich, B.; Savin, A.; Stoll, H.; Preuss, H., Chem. Phys. Lett. 1989, $157,200$.

(7) Huzinaga, S.; Andzelm, J.; Klobukowski, M. R.-A., ESakai, Y.; Tatewaki, H., Gaussian basis sets for molecular calculations. Elsevier: 1984.

(8) (a) Casida, M. E.; Jamorski, C.; Casida, K. C.; Salahub, D. R., J. Chem. Phys. 1998, 108, 4439; (b) Stratmann, R. E.; Scuseria, G. E.; Frisch, M. J., J. Chem. Phys. 1998, 109, 8218; (c) Van Caillie, C.; Amos, R. D., Chem. Phys. Lett. 1999, 308, 249; (d) Van Caillie, C.; Amos, R. D., Chem. Phys. Lett. 2000, 317, 159; (e) Scalmani, G.; Frisch, M. J.; Mennucci, B.; Tomasi, J.; Cammi, R.; Barone, V., J. Chem. Phys. 2006, 124, 94107.

(9) (a) Stephens, P. J.; Devlin, F. J.; Chabalowski, C. F.; Frisch, M. J., J. Phys. Chem. 1994, 98, 11623; (b) Yanai, T.; Tew, D. P.; Handy, N. C., Chem. Phys. Lett. 2004, 393, 51.

(10) Frisch, M. J.; Trucks, G. W.; Schlegel, H. B.; Scuseria, G. E.; Robb, M. A.; Cheeseman, J. R.; Scalmani, G.; Barone, V.; Mennucci, B.; Petersson, G. A.; Nakatsuji, H.; Caricato, M.; Li, X.; Hratchian, H. P.; Izmaylov, A. F.; Bloino, J.; Zheng, G.; Sonnenberg, J. L.; Hada, M.; Ehara, M.; Toyota, K.; Fukuda, R.; Hasegawa, J.; Ishida, M.; Nakajima, T.; Honda, Y.; Kitao, O.; Nakai, H.; Vreven, T.; Montgomery Jr, J. A.; Peralta, J. E.; Ogliaro, F.; Bearpark, M. J.; Heyd, J.; Brothers, E. N.; Kudin, K. N.; Staroverov, V. N.; Kobayashi, R.; Normand, J.; Raghavachari, K.; Rendell, A. P.; Burant, J. C.; Iyengar, S. S.; Tomasi, J.; Cossi, M.; Rega, N.; Millam, N. J.; Klene, M.; Knox, J. E.; Cross, J. B.; Bakken, V.; Adamo, C.; Jaramillo, J.; Gomperts, R.; Stratmann, R. E.; Yazyev, O.; Austin, A. J.; Cammi, R.; Pomelli, C.; Ochterski, J. W.; Martin, R. L.; Morokuma, K.; Zakrzewski, V. G.; Voth, G. A.; Salvador, P.; Dannenberg, J. J.; Dapprich, S.; Daniels, A. D.; Farkas, Ö.; Foresman, J. B.; Ortiz, J. V.; Cioslowski, J.; Fox, D. J. Gaussian09, Revision D.01, Gaussian, Inc.: Wallingford, CT, USA, 2013.

(11) Alecu, I. M.; Zheng, J.; Zhao, Y.; Truhlar, D. G., J. Chem. Theory Comput. 2010, 6, 2872. 